\title{
WestVirginiaUniversity
}

THE RESEARCH REPOSITORY @ WVU

Graduate Theses, Dissertations, and Problem Reports

2011

\section{Bashkirs between Two Worlds, 1552-1824}

\author{
Mehmet Tepeyurt \\ West Virginia University
}

Follow this and additional works at: https://researchrepository.wvu.edu/etd

\section{Recommended Citation}

Tepeyurt, Mehmet, "Bashkirs between Two Worlds, 1552-1824" (2011). Graduate Theses, Dissertations, and Problem Reports. 4803.

https://researchrepository.wvu.edu/etd/4803

This Dissertation is protected by copyright and/or related rights. It has been brought to you by the The Research Repository @ WVU with permission from the rights-holder(s). You are free to use this Dissertation in any way that is permitted by the copyright and related rights legislation that applies to your use. For other uses you must obtain permission from the rights-holder(s) directly, unless additional rights are indicated by a Creative Commons license in the record and/ or on the work itself. This Dissertation has been accepted for inclusion in WVU Graduate Theses, Dissertations, and Problem Reports collection by an authorized administrator of The Research Repository @ WVU.

For more information, please contact researchrepository@mail.wvu.edu. 
Bashkirs between Two Worlds, 1552-1824

\title{
Mehmet Tepeyurt
}

Dissertation submitted to the Eberly College of Arts and Sciences

at West Virginia University

in partial fulfillment of the requirements

for the degree of

\author{
Doctor of Philosophy \\ In \\ History
}
Mark B. Tauger, Ph.D., Chair
Robert Blobaum, Ph.D.
Joseph Hodge, Ph.D.
Josh Arthurs, Ph.D.
Willard Sunderland, Ph.D.
Department of History
Morgantown, West Virginia
2011

Keywords: Bashkirs, Russia, Russian History, Russian Empire, nationality, Islam, Central Asia, Muslims of Central Asia, Pugachev Rebellion, Tatars, Urals, frontier

Copyright by Mehmet Tepeyurt, 2011. All Rights Reserved. 


\section{ABSTRACT \\ BASHKIRS BETWEEN TWO WORLDS, 1552-1824 \\ MEHMET TEPEYURT}

This dissertation examines the transformation of the Bashkir society from a nomadic and semi-nomadic society to a sedentary society under the Russian empire's control from the sixteenth to the early nineteenth centuries. In particular, it analyzes inter-ethnic relations and the consequences of these relations for both Bashkirs and other peoples in Bashkiria.

The historical Bashkir lands formed Russia's southeastern frontier for more than two hundred years and the penetration of non-Bashkir groups into the region was a slow and arduous process. On the one hand, the region was an extremely dangerous place: the nomadic groups were quite hostile to the arrival of the agricultural groups who carved out farms from the pasturelands, thereby harming Bashkir nomadic economy. On the other hand, the Muscovite Russian governments were fairly averse to the migrations from the European parts of Russia where a labor force was most needed.

The Muscovite governments followed inconsistent policies in Bashkiria. They attempted to preserve Bashkir Votchina rights granted by Ivan IV, but on the other hand they were compelled to protect and improve their interests in the region. This was possible only by erecting fortifications and seizing territory within Bashkir lands. In the process, the Russians undermined Bashkir pastoral economy and provoked Bashkir rebellions against Russian policies in the region. The seventeenth and eighteenth centuries witnessed six major Bashkir rebellions against the Russian state. These rebellions and Russian responses transformed Bashkir society.

The Russian presence and policies had mixed results for both Russians and Bashkirs. Beginning with the enlightened policies of Peter the Great, the Russian authorities began to 
consider the natives as 'others' and increasingly took a condescending and often hostile attitude toward the indigenous people. The Russian government attempted to assimilate Bashkirs and other non-Russian peoples of the region, including measures to sedentarize nomadic Bashkirs and attempts to proselytize Orthodox Christianity among then through the Office of the New Converts after 1731.

In the long term, such efforts had mixed results. On the one hand, by the early nineteenth century most Bashkirs had shifted from pastoralism to agriculture, and became loyal Russian subjects, fighting in the Russian army against Napoleon. On the other hand, they became increasingly Islamicized. Earlier, as a pastoral people, the Bashkirs were not suited to the practice of Islam and their adoption of this monotheistic religion remained largely superficial. The Russian policies of repression and sedentarization of Bashkirs inspired and enabled their full embrace of Islam (because Islam is largely a religion for sedentary societies) as an ideological means to preserve their distinct Bashkir identity.

By the 1820s Bashkir society was economically and ideologically a more coherent body. Their pastoral economy had been shattered through the migrations to the region and the Russian policy of fortified lines and their superficial Islam had given way to orthodox Islam. Their rebelliousness had been broken but their resistance to Russian assimilation gained another dimension as a national group. Consequently the imperial policies of the Russian authorities had modernized a native group and connected them to the wider world. 


\section{TABLE OF CONTENTS}

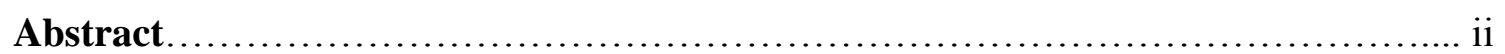

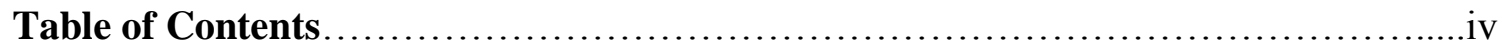

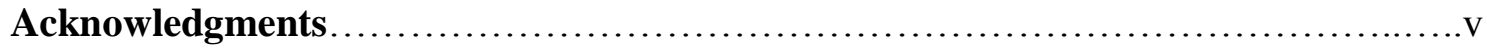

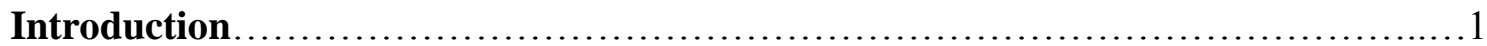

Frontier Studies...............................................................

Conversion to Islam........................................................... 4

Nationalism ................................................................ 8

New Imperial History .................................................. 9

\section{Chapter 1}

The Beginning of the Russo-Bashkir Relations.................................... 16 The Russians' First Extension of Sovereignty over Bashkiria, $15^{\text {th }}-17^{\text {th }}$ Centuries.. 16 Russians as Patrons of Bashkirs.................................................20 Initial Russian Administrative Policies..........................................26 Bashkir Society in the late $16^{\text {th }}$-early $17^{\text {th }}$ Centuries...............................30

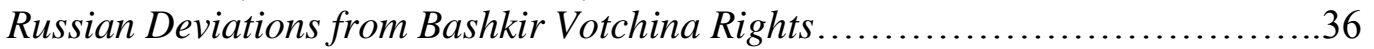

Conclusion.................................................................40

\section{Chapter 2}

Bashkirs and Russian Wars of the Seventeenth and Early Eighteenth Century.

Russo-Bashkir Relations in the Period of Early Russian Modernization, ............43 $17^{\text {th }}$-Early $18^{\text {th }}$ Centuries Russian Administration of the Bashkirs in the $17^{\text {th }}$ Century........................47

Bashkir Rebellions of the Mid-16 $6^{\text {th }}$ - Early $17^{\text {th }}$ Centuries...........................52

The Russo-Bashkir Wars in the $17^{\text {th }}$ Century and Steppe Politics....................58

The Bashkir Rebellion of 1662-1664.........................................60

Muscovite-Bashkir Conflicts, 1681-1684 and 1704-1711..........................75

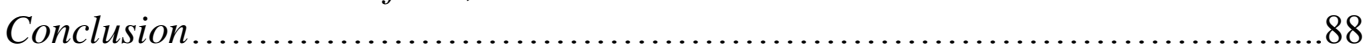

\section{Chapter 3}

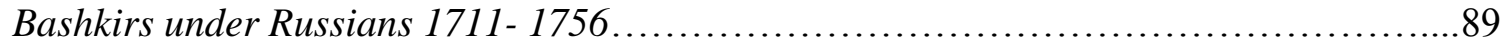

Imperial Russia's Bashkir Frontier, 1700-1734...............................91

New Imperial Projects in Bashkiria ....................................... 94

Bashkir Moves against the New Imperial Projects...............................104

The Apogee of Russo-Bashkir Conflict: the 1735-1740 War.....................118

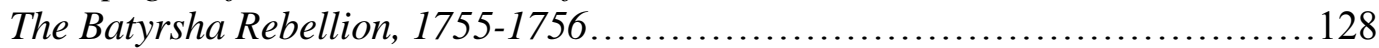

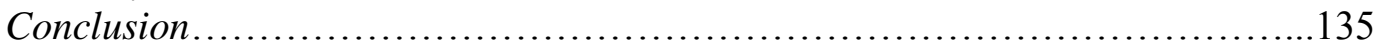




\section{Chapter 4}

Strange Bedfellows: Bashkirs during the Pugachev Rebellion

Background: The Russian Government and the Urals Nationalities

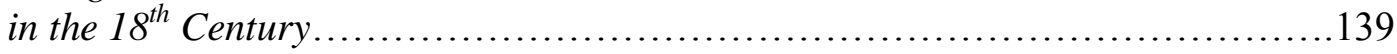

The Bashkirs and the Beginning of Pugachev's Rebellion ..........................141

The Bashkirs and Conflicts within Pugachev's Forces............................. 146

The Bashkirs between the Russian Government and Pugachev........................151

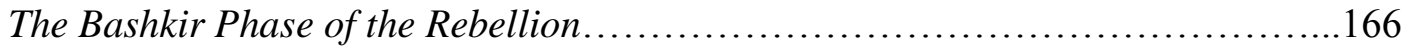

Conclusion............................................................. 171

\section{Chapter 5}

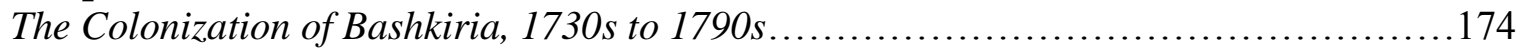

Historiography.......................................................... 175

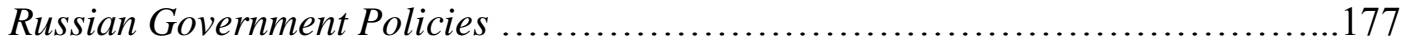

Actual Migrations......................................................... 181

Relations between Natives and Migrants..................................... 193

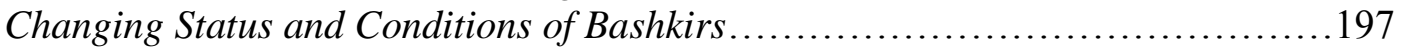

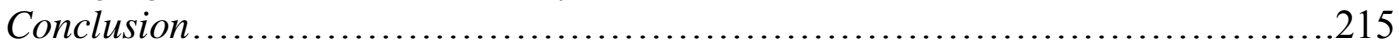

\section{Chapter 6}

The Islamization of Bashkirs......................................................217

Bashkirs' Conversion to Islam, 900s to 1300s.................................218

Bashkirs' Embrace of Islam and Russia's Muslim Question.......................223

Bashkir Rebellions in Defense of Islam...........................................226

Bashkirs' Islamization and the Impact of Tatars.................................2234

Efforts to Convert Peoples of the Volga-Ural Region...............................2239

The Batyrsha Incident, 1755-1756......................................... 241

Catherine the Great's Policy of Religious Toleration.............................245

Bashkir Popular Islam.....................................................253

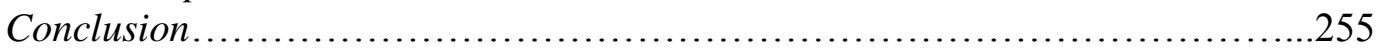

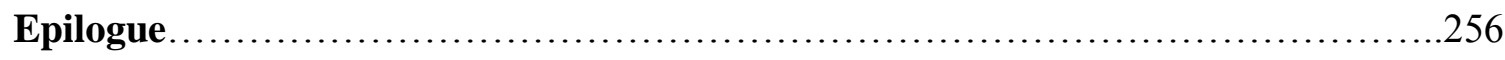

Works Cited................................................................... 263 


\section{ACKNOWLEDGMENTS}

History is like uncharted waters and without a good guide it is very easy to get lost. Mark Tauger was the best guide I could ever imagine. This dissertation would be impossible to complete without knowledge and insight of my advisor Mark Tauger. Whenever I lost my direction and encountered writer's block many times, he always encouraged and supported me to resume my studies.

I also owe my special thanks to my committee members; Robert Blobaum, Joseph Hodge, Josh Arthurs and Willard Sunderland who kindly accepted to join my dissertation committee. They all provided many insightful comments and brought new dimensions to the dissertation.

My colleagues Isaac Emrick and Jason Roberts provided me best possible support in the office. They did not hesitate to share their thoughtful comments and produced necessary maps for my thesis. The cordiality and friendship of my colleagues in graduate school, particularly Charles Dusch, Melinda Hicks, Charles Steinmetz, James de Palma, Charles Keeney, Michael Buseman, Laura Nelson, Jordan Lieser is unforgettable. It has been a pleasure to work with such ineffable people. I must also mention my Turkish friends in Morgantown, WV., Egemen Ogretim, Bayram Ali Demircan, Murat Gul and their graceful wives, Gulsum Ogretim, Berrin Demircan, and Betul Gul. They made my life in Morgantown easier and more comfortable with their company.

Most importantly I owe my most grateful thanks beyond measure to Zahide. She cordially shared all my difficult moments and sacrificed a lot until the completion of my dissertation. Without her this work would have no meaning. Thank you my only.

Last but not least this work is dedicated to my parents, in particular my late father, who sacrificed their lives for my education. 


\section{Introduction}

One of the most salient themes of Russian history is its frontier and its struggle with either nomadic or sedentary people. In part Russia's history is the history of a relentless expansion to the disadvantage of its eastern and southern nomadic neighbors which gained momentum after the fall of Kazan in 1552. After this date, Russia increasingly added new lands and peoples to its ever growing empire. Between 1600 and 1900 Russia added an average of 57,000 sq. $\mathrm{km}$ every year. ${ }^{1}$ The unrelenting movement to the east and south made Russia for centuries an empire of almost endless frontiers. This territorial expansion brought many different ethnic linguistic and economic groups under Russian control, from sedentary Muslim Volga Tatars to hunting-gathering animist Siberian groups such as Mansis and Samoyeds. Russians benefited from this territorial growth in various ways. But it also brought cataclysmic changes to the indigenous peoples. While some of these peoples were unable to cope with the new situations, others were able to transform themselves to coexist side by side with the newly arriving Russians and non-Russian neighbors.

This dissertation examines the period from 1552 to 1824 during which the Bashkir lands formed Russia's eastern and southeastern frontier, barring further Russian expansion to the southeast. The Bashkirs relentlessly resisted Russian intrusions. In this respect, they were much more successful than many other non-Russian groups who fell victim to Russia's encroachments. There are three actors or groups of actors on this frontier- the Russian state, indigenous people, and various settler groups. This thesis centers on an example of the second group: the Bashkirs who lived along the Volga-Ural region.

My research initially focused around a nomadic group which inhabited the fringes of a great empire and it seemed to me a great topic for frontier studies. However as my studies

\footnotetext{
${ }^{1}$ J. P. Cole, Geography of the Soviet Union, (London: Butterworths, 1984), 9.
} 
evolved, I realized that the Russo-Bashkir case was more than a frontier study. This dissertation has theoretical and historiographical roots in four areas: recent frontier studies, the history of conversion to Islam, certain elements of nationalism, and the new imperial history.

\section{Frontier studies}

This dissertation is an attempt to bring a much neglected community to light with a frontier perspective. As frontier people Bashkirs' history deserves much attention and will contribute to frontier studies.

The frontier thesis was first introduced by Frederick Jackson Turner in the 1890s. Since then, a field of frontier studies has developed that has refuted Turner's thesis to a great degree. Turner regarded the frontier as a point where savagery and civilization met while virtually ignoring land conflicts. In his view the frontier offered free land ready to be picked up by civilized people. For Turner, Indians were faceless impersonal individuals. The focus was on the white men. His thesis was fraught with defects and abandoned by the 1980s though the concept has survived and developed into a model for other parts of the world which, enables scholars to construct analogies and grasp new dimensions of local histories. In the 1980s, a new approach in the frontier studies emerged which reinterpreted Turner's thesis. One of them, The Frontier in History: North America and Southern Africa Compared by Howard Lamar and Leonard Thompson conceives of the frontier as a zone or territory, rather than a boundary or line, in which an interpenetration of two previously distinct societies takes place. The frontier, for them, opens with the arrival of the first representatives of the intrusive society and closes when one of them (either intrusive or indigenous) emerges as the sole authority in the region. In 
between, the relations between the intruder and the indigenous develop in various ways. They establish a symbiotic coexistence from which both parties benefit. ${ }^{2}$

For Lamar and Thompson a frontier can close in different ways: the total extermination of the indigenous population, their banishment, or their incorporation into the intruders' political and economic system. In the Bashkir case this is an insufficient explanation or at least requires further clarification. I argue that the frontier closes only in the case of total extermination of the indigenous population or its complete assimilation into the intruder's culture. Otherwise the tensions may decline and seem to disappear temporarily, but there is always a dormant potential that the frontier issue may surface again under the suitable conditions like the collapse of central authority or a pervasive civil war. For most of the time the relations between the intruder and the indigenous remain uneasy. Economic, cultural or religious clashes may keep occurring even after the military defeat.

Aside from clashes I regard the frontier as a field of interaction by two or more distinct groups. It is mostly a fertile ground for development of different ways of living and a field for acculturation, as a result of which one group becomes more like the other by borrowing elements missing from its own culture from a different culture. Richard White asserts that acculturation is a process in which the dominant culture dictates the correct behavior to the subordinate one. ${ }^{3}$ I argue that in the Bashkir case there was such a process by which the Russians created suitable conditions under which the Bashkirs accommodated themselves to the new situation.

Stating this, I regard the frontier as a zone of interaction from which the ubordinate group also benefits and conflict is only a part of the interaction. The distinct groups live together with

\footnotetext{
${ }^{2}$ Howard Lamar \& Leonard Thompson, ed. The Frontier in History: North America and Southern Africa Compared (New Haven: Yale University Press, 1981), 7.

${ }^{3}$ Richard White, The Middle Ground; Indians, Empires and Republics in the Great Lakes Region, 1650-1815 (Cambridge: Cambridge University Press, 1991)
} 
certain tensions of course, they make business, form marriage alliances and at times they fight shoulder to shoulder against a declared common enemy as in the case of the Pugachev Rebellion in 1774-1776. This relationship between Bashkirs and Russians is in line with that of Indians and Europeans on America's frontier.

A new approach between the colonizer and the colonized in America was formulated by Robert F. Berkhofer, Jr. in a short article and he argued that Indian history writing should take new directions to understand the complex relationship between White men and Indians.

However, he added, the focus of this new history must be based on the history of Indians and a new history of America must be written from the perspective of Indians. ${ }^{4}$ In the wake of this article and some other works that stressed the same point point of view, new scholarly works appeared in the subsequent years which gained momentum in 1980s and 1990s. New Indian historians such as James Axtell, James H. Merrell, Daniel H. Usner and Richard White have stressed exchanges between Europeans and Indians in commerce, diplomacy, and society as a counterbalance to conflict. $^{5}$

\section{Conversion to Islam}

Sedentary peoples such as Russians, Tatars, and Finnic groups influenced the formation of the nomadic Bashkirs' ethnic identity with strong religious elements. As stated by Allen J. Frank, the Bashkirs' Islamization took place soon after their overlords, the Golden Horde,

\footnotetext{
${ }^{4}$ Robert F. Berkhofer, Jr., "The Political Context of a New Indian History," Pacific Historical Review, 40, No. 3 (Aug., 1971): 357-382.

${ }^{5}$ For a limited collection of books published in the context of new Indian History see Richard White, The Middle Ground; Indians, Empires and Republics in the Great Lakes Region, 1650-1815 (Cambridge: Cambridge University Press, 1991); Daniel H. Usner, Indians, Settlers \& Slaves in a Frontier Exchange Economy: The Lower Mississipi Valley before 1783 (Chapel Hill and London: University of North Caroline Press, 1992); James Axtell, Natives and Newcomers: The Cultural Origins of North America (Oxford: Oxford University Press, 2001); James H. Merrell, The Indians' New World: Catawbas and Their Neighbors from European Contact through the Era of Removal (University of North Carolina Press, 2010)
} 
converted to Islam in the fourteenth century. ${ }^{6}$ But due largely to their nomadism, the Bashkirs remained only nominal Muslims. Even then their nominal Islamism posed certain problems since they had chosen the Hanafi School of Islam, the most urban and intellectually sophisticated Islamic school and the least suitable school for a nomadic group. This gives us clues that their early conversion to Islam was not a conscious choice, but rather an imposition by their Mongol masters.

In the Turkic world there are certain models of conversion to Islam. One of them is conversion through assimilation which could be seen among the slave armies of the Abbasids whose elite troops were Turkish slave soldiers. The other one is the Imperial conversion as evidenced by the Qarahanids who converted to Islam in the 930s when their king embraced Islam. Tribal conversion offers another model as in the case of the Saljuks in the late $10^{\text {th }}$ century. The tribal chief's acceptance of Islam led the lesser clans to adopt their chiefs' belief. ${ }^{7}$ The Bashkirs' conversion took the third form when tribal chiefs decided to convert to Islam without fully embracing the major tenets of Islam.

Islam generally played a transforming role in the life of newly converted communities. At the beginning of the process, a formal and often hierarchical religious authority structure emerged. In time the religious authority received a degree of legal autonomy from the political authorities. In the daily life the religious vocabulary found more room in vernacular language for purposes of exegesis or religious instruction. Finally the religious authorities found a place

\footnotetext{
${ }^{6}$ Allen J. Frank, Islamic Historiography and Bulghar Identity among the Tatars and Bashkirs of Russia (Leiden: Brill, 1998), 8.

${ }^{7}$ Devin A. DeWeese, Islamization and Native Religion in the Golden Horde: Baba Tükles and Conversion to Islam in Historical and Epic Tradition, (University Park: Pennsylvania State University Press, 1994), 9.
} 
for themselves in the society as spokesmen for the religious community and as exemplars of religious life. ${ }^{8}$

This schemes of conversion that Richard W. Bulliet created for sedentary societies to a great degree conflicts with the history of the nomadic Bashkirs. In the Bashkir case there was no formal and hierarchical religious authority but rather abyz tribal elders. ${ }^{9}$ Because the Bashkirs were a stateless society, the religious elite developed their own legal autonomy from the tribal leaders by posing as masters of wisdom. The fusion of religious and vernacular language can be detected from the Islamization of the names of individuals. Another indicator of Islamization is the spread of the use of the term Mulla ${ }^{10}$ for religious personalities. The term Mulla replaced Abyz as the Islamization of Bashkirs reached its maturity around the end of the eighteenth century. Also religious authorities emerged as the spokesmen of the Bashkir society when the tribal leaders were either exterminated during the wars against the Russians or were incorporated in the $1600 \mathrm{~s}$ and $1700 \mathrm{~s}$.

The Bashkirs' conversion to Islam was largely incomplete or at least delayed for a very long time. This delay is not surprising because it is a common pattern throughout the Turkic Islamic world that conversion to Islam and elaboration of Islamic institutions took place at

\footnotetext{
${ }^{8}$ Richard W. Bulliet, Conversion to Islam in the Medieval Period; An Essay in Quantitative History, (Cambridge: Harvard University Press, 1979), 34-35.

${ }^{9}$ Abyz was a common title in the seventeenth and eighteenth centuries for Volga-Ural ulama, and seems to have indicated any learned person. Literally it means a person who learned Quran by heart. By the first half of the nineteenth century the term appears to have been replaced by the title mulla.

${ }^{10}$ Mulla, a much more inclusive term than abyz, denoted an individual possessing a degree of religious authority and education among the Muslims of the Volga-Urals region; according to the official definition of the term in the nineteenth century any Islamic scholar with a status lower than the mufti and higher than müezzins was a mulla. Literally Mulla means a man who mastered several Islamic religious fields. In this sense Mulla is a more sophisticated person than abyz. Presumably a mulla is expected to know Quran by heart. Etymologically it is Mevla, a Arabic word, and means master, pathfinder, helper, educator. With this switch of words from abyz to mulla, one can detect the rise of religious men to the leadership of the Islamic Bashkir community.
} 
different times as a result of a sedentarization process. ${ }^{11}$ As the sedentarization process took longer, so too did the institutionalization of Islam and the penetration of Islam into the daily lives of people.

The events that accelerated this conversion process took place after 1552 when Bashkiria received a high number of devoutly Muslim Tatar refugees escaping from Russian repression. As intruders, Russian policies in Bashkiria after the 1550s led to a series of indigenous rebellions that shaped the Bashkirs' national and religious character embodied by myths and legends.

Religious revival of the frontier Bashkirs was not surprising or unique. The frontier historian William Cronon asserts that frontier areas offer the best ground for conservative social movements which seek to withstand cultural change and the conveyors of this new culture, in our case Russians. It is by no means surprising that religious revival as cultural revitalization occurred frequently in the frontier areas. Most of the downtrodden indigenous groups yearned for bygone times. ${ }^{12}$ Unlike their previous limited acceptance of Islam, the Bashkirs this time found willing companions, the Volga Tatars, who helped them to revive and form their Islamic consciousness.

Though Russians deliberately avoided using force to Christianize Bashkirs, their destruction of the traditional Bashkir life was so sweeping that the Bashkirs had no other alternative but to embrace Islam presented to them by the Volga Tatars who had also been victimized by the Russians. The increasing Islamization of the Bashkirs became noticeable as the leadership of the Bashkir community fell into the hands of religious figures who had led Bashkir rebellions against the Russians on several occasions. So it can be asserted that

\footnotetext{
${ }^{11}$ Richard W. Bulliet, Conversion to Islam in the Medieval Period; An Essay in Quantitative History, (Cambridge: Harvard University Press, 1979), 3.

${ }^{12}$ William Cronon, George Miles and Jay Gitlin, "Becoming West: Toward a new Meaning for Western History" in Under an Open Sky; Rethinking America's Western Past, ed. William Cronon (New York: W. W. Norton \& Company, 1992), 19.
} 
Islamization brought a shift in the social structure of the Bashkirs and a revival in their spiritual life, as well as a greater determination to resist assimilation attempts by the Russians. Though the Russians were more successful in other frontier regions, in Bashkiria, Islam increased the chances of "backward" Bashkirs surviving as an ethnie.

\section{Nationalism}

The Bashkirs' formation as an ethnic community, separate from Volga Tatars, was based on their nomadic past, tribal traditions, land grants from the Russian tsar and events that were triggered by this land grant including their wars against the Russians. By the end of the eighteenth century an ambiguous Bashkir identity had emerged which lacked secular dimensions. The formation of Bashkir nationality is related to a radical change in their life style from nomadism to sedentarism. This shift produced anachronistic results in Bashkirs' nationalization due to the fact that Bashkirs' development of a national identity lacked an urban intellectual basis but rather, as an indicator of their isolation from the modern world i.e., Western Europe. In the case of the Bashkirs, it was a retroactive development inspired by religious awakening which lacked secular dimensions. The Tatars' impact upon the Bashkirs was in this sense remarkable, since they also belonged to a fading age of religious sensibilities surrounding themselves with the long void of theological arguments that influenced their political behavior. I will argue that the Bashkirs' incipient nationalization process was a byproduct of their common struggle against the Russians and other sedentary communities in defense of their nomadic life rather than the result of a premeditated intellectual movement.

Benedict Anderson argues that nationality or "nation-ness" is a cultural artefact. ${ }^{13} \mathrm{My}$ purpose is not to examine Anderson's premise but rather to argue that the emergence of Bashkir

\footnotetext{
${ }^{13}$ Benedict Anderson, Imagined Communities; Reflections on the Origin and Spread of Nationalism revised edition, (Verso: London, 1991), 4.
} 
ethnic identity was a natural result of several historical developments including their sedentarization and Islamization. I will define the reasons and conditions that paved the way for the emergence of a distinct Bashkir ethnie. In this respect, I will use Anthony D. Smith's definition of ethnie which states that "Ethnie (ethnic Communities) may be defined as named human populations with shared ancestry myths, histories and cultures, having an association with a specific territory and a sense of solidarity.",14

\section{New Imperial History}

My study of the Bashkirs seeks to contribute to a major new trend in historiography about the Russian empire that began around the tie of the Soviet collapse in 1991. This new literature challenges the earlier, "cold war" historiography that viewed the Russian Empire as a "prisonhouse" of nationalities held together only by force. The new writings, based on a much more careful and more extensive use of sources, generally argue that the peripheral nationalities living in Russia's borderlands while often victimized, also often benefited from Russian rule. In most cases, Russian authorities in return for loyal services and poddanstvo (literally citizenship) distributed to the local elite service opportunities, privileges, gifts and a guarantee for the continuation of their dominant position in their native societies. As a result of these mostly tolerant imperial policies, indigenous groups remained relatively unchanged from a cultural perspective, a situation which Thomas Barrett calls 'underassimilation.'15

The new literature has shown that imperial rule was a much more complex mechanism than simply a brutalizing omnipotent force which imprisoned nationalities. As was discussed by Willard Sunderland in his analysis of Boris Mironov's book, Sotsial'naia Istoriia Rossiia, 'the

\footnotetext{
${ }^{14}$ Anthony D. Smith, "Structure and Persistence of Ethnie in Montserrat Guibernau." In The Ethnicity Reader: Nationalism, Multiculturalism and Migration, 2. edition, ed. John Rex, (Polity Press: Cambridge, 2010 ), 27. ${ }^{15}$ Thomas M. Barrett, At the Edge of Empire: The Terek Cossacks and the North Caucasus Frontier, 1700-1860 (Boulder -Colorado: West View Press, 1999), 190.
} 
relative gifts of the Pax Russica have been generally underappreciated. ${ }^{16}$ The key study that opened this new approach was Andreas Kappeler's book Russland als Vielvolkerreich:

Entstehung, Geschichte, Zerfall, which was translated into English in 2001 as The Russian

Empire: A Multiethnic History after the collapse of the USSR. Generally scholars of the field agree that Kappeler's book opened new venues in this field and its influence was so great that according to Austin Jersild Kappeler simply created a sub-field within the study of imperial Russian history. ${ }^{17}$ Kappeler sought to write a study of the empire that focused on the nonRussian nationalities. Even though the study was somewhat flawed because it did not examine the Russians as an ethnic group, still it continues to influence the ongoing Anglo-American history writing regarding Russian imperial history. Kappeler's book inspired numerous additional studies of the Russian empire and imperial borderlands in the 1990s and 2000s. This period can be called the era of "imperial boom." ${ }^{18}$ The number of studies dealing with various nationalities of the Russian Empire increased by leaps and bounds in 2000s. ${ }^{19}$

\footnotetext{
${ }^{16}$ Willard Sunderland, “Empire in Boris Mironov's Sotsial'naia Istoriia Rossii," Slavic Review 60, (Autumn 2001): 573.

17 Austin Jersild, "Russia, from the Vistula to the Terek to the Amur," Kritika: Explorations in Russian and Eurasian History 1, (Summer, 2000): 533 (Review)

${ }^{18}$ For a limited collection of essays and books published in 1990s, see Daniel R. Brower and Edward J. Lazzerini, eds., Russia's Orient: Imperial Borderlands and Peoples, 1700-1917 (Bloomington: Indiana University Press, 1997); Jane Burbank and David L. Ransel, Imperial Russia: New Histories for the Empire (Bloomington: Indiana University Press, 1998), especially Thomas M. Barrett and Willard Sunderland's essays pertaining to interactions between Russian settlers and native aliens are revealing; Michael Khodarkovsky, Where Two Worlds Met: The Russian State and the Kalmyk Nomads, 1600-1771 (Ithaca and London: Cornell University Press, 1992)

19 Just some of them are as follows: Christian Noack, Muslimischer Nationalismus im Russischen Reich: Nationsbildung und Nationalbewegung bei Tataren und Baschkiren, 1861-1917 [Muslim Nationalism in the Russian Empire: Nation-Building and National Movements among the Tatars and Bashkirs, 1861-1917]. (Stuttgart: Franz Steiner Verlag, 2000); Jane Burbank, Mark Von Hagen, and Anatoly Remnev, eds., Russian Empire: Space, People, Power, 1700-1930 (Bloomington: Indiana University Press, 2007); Robert P. Geraci and Michael Khodarkovsky, eds., Of Religion and Empire: Missions, Conversion, and Tolerance in Tsarist Russia (Ithaca, NY: Cornell University Press, 2001); Robert D. Crews, For Prophet and Tsar; Islam and Empire in Russia and Central Asia (Cambridge Mass. Harvard University Press, 2006); Willard Sunderland, Taming the Wild Field: Colonization and Empire on the Russian Steppe (Ithaca, N.Y.: Cornell University Press, 2004) Sunderland's work is a valuable contribution to the borderland studies but his focus is more on the steppe region and Russian settler colonialism rather than some particular non-Russian nationalities of the steppe region.
} 
These decades also witnessed the emergence of two new periodicals which have particularly focused particular attention on the imperial Russian history. These journals provided venues for new imperial historian who received their doctoral degrees in 1990s in the wake of growing imperial studies with new focus on the peoples of the borderlands. The first one, Kritika, appeared in winter 2000 based in the University of Maryland. Its subtitle, Explorations in Russian and Eurasian History, redefines the field in light of the fact that the last Russian Empire, the USSR, divided into 15 republics, most of which themselves contain semiautonomous national regions. Before 1991 the huge Eurasian mass was dominated by the USSR which was a continuation of the Russian empire. But now in the same mass there are national states and Russia is just one of them. These newly independent states have their own history which has now to be studied with little Russian focus. So the use of the term Eurasia signals a shift from the St. Petersburg or Moscow centered perspectives in writing history of the vast spaces and multitudes of nationalities.

The other new periodical, Ab Imperio, is published in Kazan but attracts both Russian and Western scholars as contributors though it is largely a Russian language periodical. It made its first appearance in 2000 with a subtitle "Studies of New Imperial History and Nationalism in the Post-Soviet Space.” The starting point of this new focus on Eurasianism, as Mark von Hagen pointed out, is to constitute an anti-paradigm against two former paradigms (Russia/Orient and Soviet Union/Modernization) that dominated the field until recently. ${ }^{20}$

Despite this new trend in the literature, the history of Islam and Muslim communities in Russian Empire remains relatively little investigated. ${ }^{21}$ This area is extremely important both

\footnotetext{
${ }^{20}$ Mark von Hagen, "Empires, Borderlands, and Diasporas: Eurasia as Anti-Paradigm for the Post-Soviet Era" American Historical Review 109, No: 2, (2004): 448.

${ }^{21}$ Robert D, Crews' book is a good attempt to update a comprehensive history of Islam in Russia. Robert D. Crews. For Prophet and Tsar: Islam and Empire in Russia and Central Asia. (Cambridge, Mass.: Harvard University Press,
} 
because of the role of Muslim groups in Russian history and because of their growing significance in the region today. In this context, my study examines a Muslim Turkic group of people, Bashkirs, who populated Russia's southeastern frontier more than two hundred years and how they benefited in the long run from the Russian rule despite the fact that they were largely victimized by the Russian rule. I seek to contribute to this field specifically on the history of Islam and Muslim groups in the Empire, because the field despite its spectacular growth still lacks certain themes.

We still need to have a good history of the Orenburg Muslim Spiritual Assembly in English language. There are a few articles mainly by Danil D. Azamatov but they do not fill the gap. At least his book in Russian called Orenburgskoe Magomentanskoe Dukhovnoe Sobranie v Kontse 18-19vv. could be translated into English. Smaller national groups are also neglected under more pervasive fields like Caucasus or Central Asia. In this context, when it comes to Bashkirs a certain Volga-Ural regional history dominates the scholarly studies while Bashkir history succumbs to that of much more popular Volga Tatars.

One of my starting points in writing a history of Russo-Bashkir relations was that despite Bashkirs' success in preserving their national identity against great odds; they were largely understudied in the West. Neither in the field of Imperial studies nor in the frontier studies was much written about them. There are only two scholars in the west who have specifically studied Bashkiria. Alton Donnelly's works belong to an earlier era. He mainly analyzed Russian policies and practices in Bashkiria but devotes little or no attention to the Bashkirs' point of view. Its real value derives from the point that it was the first western scholarly work genuinely dealing with Bashkirs during the imperial period. The works of Charles Steinwedel devote more 
attention to Bashkirs than Donnelly and his PhD. thesis focuses on the state formation and the integration of Bashkiria into the Russian system. He analyzes the transformation of the Bashkir society in the nineteenth century and examines the patterns of Bashkirs' integration into the Russian imperial system and he occasionally brings Bashkir point of view to the fore and explains how Bashkirs benefited from imperial integration. As distinct from Steinwedel I analyze earlier period of Russo-Bashkir relations from $1550 \mathrm{~s}$ to $1820 \mathrm{~s}$ and argue that the development of a distinct Bashkir identity became possible only with the incorporation of the region into the Russian Empire. Both, Donnelly and Steinwedel, devote inadequate attention to Bashkirs because a pure Bashkir history is nearly impossible due to the long presence of the Russians in the region. ${ }^{22}$ Recognizing this facet of the Bashkir history relying on the available published sources I have focused on the history of Bashkirs to the extent published primary sources allowed.

There is a need to write the history of the Volga-Ural region and its peoples with a regionalist approach focusing on the individual nationalities, their respective histories and their relations to the Russians. In this way the multinational character of the empire could be better revealed. This regionalist approach still needs to be defined with a certain methodology as well. An all-encompassing (comprehensive) history of the Volga-Ural region runs the risk of ignoring smaller nationalities in favor of more populous/dominant groups as happened in the past.

\footnotetext{
${ }^{22}$ Alton S. Donnelly, The Orenburg Expedition: Russian Colonial Policies on the Southeastern Frontier, 1734-1740 (University of California, 1960 Ph.D. ); Alton S. Donnelly, The Russian Conquest of Bashkiria, 1552-1740: A Case Study in Imperialism (New Haven and London: Yale University Press, 1968); Charles Steinwedel, Invisible Threads of Empire: State, Religion, and Ethnicity in Tsarist Bashkiria, 1773-1917 (Columbia University, 1999 Ph.D.) See also Charles Steinwedel, "Tribe, Estate, Nationality? Changing conceptions of Bashkir Particularity within the Tsar's Empire" Ab Imperio: Theory and History of Nationalities and Nationalism in the Post-Soviet Realm, 2 (2002): 249-278.
} 
Scholars have to consider the risk of focusing too much on single nationalities which may cause ethnicization, "concentrating too much on one ethnic group while marginalizing the rest.",23

In the west, the existing scholarship about Volga Ural region pertaining to Imperial period is developing. For example one of the most important sources of the Bashkir culture from 1300s called Kissa'i Yusuf (The story of Joseph) was finally translated into English. ${ }^{24}$ Earlier Allen J. Frank's works on the Volga-Ural region gave a new impetus to Volga-Ural history. He contributed to the field with a number of works and commentaries that pointed to the availability of local manuscripts written by Muslim scholars which still remain untranslated. ${ }^{25}$ Their translation into English will enable the scholars to study the history of the people of the region from indigenous point of view and will free them from the Russian scholarly approach to these indigenous people.

My second point in writing such an essay is that despite their traumatic history Bashkirs nevertheless managed to survive as a distinct group not exterminated by Russians and not assimilated by a much more sophisticated Volga Tatar culture. Bashkirs at the beginning of the Russian rule in 1550 s were, culturally and economically, the least advanced group and the Bashkir identity unlike a number of other people with a considerable population in the region, like Bobyls and Teptiars, who submerged into either Tatar or Bashkir national groups, survived to this day. In this study I analyze the factors that enabled Bashkir survival and their complex relations with Russians and other non-Russian groups who moved into the region, thereby gradually changing the Bashkirs' traditional way of life.

\footnotetext{
23 Aleksei I. Miller, "Between Local and Inter-Imperial Russian Imperial History in Search of Scope and Paradigm" Kritika: Explorations in Russian and Eurasian History, 5, (2004), 12.

${ }^{24}$ Fred Beake, Ravil' Bukharaev, trans. The Story of Joseph / Kissa'i Yusuf (Folkestone, UK : Global Oriental, 2010)

${ }^{25}$ Allen J. Frank, Islamic Historiography and "Bulghar" Identity among the Tatars and Bashkirs of Russia (Boston: Brill, 1998); Allen J. Frank. Muslim Religious Institutions in Imperial Russia: the Islamic World of Novouzensk District and the Kazakh Inner Horde, 1780-1910, (Boston: Brill, 2001); Allen J. Frank, Tatar Islamic Texts (Hyattsville, MD: Dunwoody Press, 2008)
} 
In writing this essay I encountered a number of difficulties, as all doctoral students did. Because of visa problems and obligatory military service in Turkey I was unable to leave the USA to conduct archival research in Russia. As a result most of the sources are secondary sources from the Imperial, Soviet or Federal Russia period but I endeavored to reinterpret the existing literature with a new outlook. On the other hand I widely used published primary sources in Russian under the title Materialy po Istorii Bashkirskoi Istorii, a six volume serial, which enabled me to get most of the materials in writing this essay. Another published primary source was Ravil Kuzeev's Bashkirskie Shezhere (Bashkir Genealogy) that provided valuable information about the early Russo-Bashkir relations for the sixteenth century Volga-Ural region. Imperial Russian publications like Trudy Orenburgskoi Uchenoi Arkhivnoi Kommissii also provided much needed archival materials. I also directly quoted from the archival materials from the Russian scholars' works and reinterpreted them with a new outlook. 


\section{Chapter 1 The Beginning of the Russo-Bashkir Relations}

Russians conquered their age-old enemy the Kazan Khanate in 1552. It was at this point, they came in contact with the Bashkirs, who were former vassals of the Kazan Tatars. Unlike other groups, the Bashkirs became militarily the most troublesome subjects of Russians for more than two hundred years from 1552 to 1775 . During this period they effectively prevented Russian advance toward Central Asia. Despite this situation, Russians never developed any specific hatred against them as they did against the Kazan Tatars. It is no wonder that Kazan was deliberately destroyed and Kazan Tatars were persecuted by the Russians as revenge for 200 years of the Mongol yoke. The Bashkirs, however, never established any independent state and they never raided Russian territory by themselves. Accordingly the Russian attitude toward Bashkirs was one of cold indifference for the most part of the history of their interactions. .

\section{The Russians' First Extension of Sovereignty over Bashkiria, $15^{\text {th }}-17^{\text {th }}$ Centuries}

My purpose in this section is to present some aspects of the Bashkir way of life that most radically that most radically differed from the Russians' way of life and that did not meet the requirements of the new conditions. The two opposing cultures, Bashkirs and Russians, first established political relations after the fall of Kazan in 1552. The Russians as a sedentary group found it difficult to develop a well-set political program pertaining to the Bashkirs' nomadic culture. The Bashkirs, on the other hand, lacked the necessary mindset to appreciate the true nature of the quite different civilization represented by Russians. Russians demanded a number of obligations from the Bashkirs, including recognition of Russian suzerainty, and paying yearly 
tribute in the form of Iasak. ${ }^{1}$ For the Bashkirs this was not something new as they used to pay Iasak to their previous masters, Nogai, Kazan and Sibir Khanates. The potential trouble was not the expectations of these obligations from the Bashkirs, but the Russians' lack of deliberate goals in Bashkiria. They had no master plan for dealing with these these nomadic people. It was for this reason that Russians had so many troubles with the Bashkirs as they attempted to bring them into their fold and incorporate Bashkir lands into Russia.

Russians appeared in Bashkir lands as early as the 1460s as hunters. At the beginning of the sixteenth century there were a few Bashkir groups in the Muscovite Russian Empire, mostly because of westward migration of some Bashkir clans. ${ }^{2}$ The Russians' appearance in the area as a political and military force took another century, only after the annihilation of the Kazan Khanate which constituted a major barrier to Russian expansion to the east in 1552. The Russian victory over the Kazan Khanate was one of several Russian attempts to break their isolation. This policy intensified in the process that transformed Russia from a derelict Muscovite principality into post-Petrine Imperial Russia.

Soviet historians have had heated debates about the nature of the first Russo-Bashkir relations after the fall of Kazan. It is almost universally accepted that Bashkirs were incorporated into the Russian empire in 1557 as a result of peaceful negotiations between Russian authorities and Bashkir elders and that this incorporation had progressive results for

\footnotetext{
${ }^{1}$ Iasak had a symbolic meaning in the eyes of Bashkirs which signified their submission to the Russian state also marked their right to the land. Bashkirs continued to pay Iasak to the Russian government until 1754.See, N. G. Ustiugov, et.al., Ocherki po Istorii Bashkirskoi ASSR, v. 1, part 1, (Ufa: Bashkirskoe Knizhnoe Izdatel'stvo, 1956), 216.

${ }^{2}$ R. M. Raimov, 1905 God v Bashkirii: Revoliutsionnoe Dvizhenie v 1905-1907 gg. (Moskva \& Leningrad: Izdatel'stvo Akademii Nauk SSSR, 1941), 9; See also A. P. Chuloshnikov, "Feodal'nye Otnosheniia v Bashkirii i Bashkirskie Vosstaniia 17 i Pervoi Poloviny 18 vv." in Materialy po Istorii Bashkirskoi Istorii, part 1: Bashkirskie Vosstaniia v 17 i Pervoi Polovine 18 vv. (Moskva\&Leningrad: Izdatel'stvo Akademii Nauk SSSR, 1936), 22. The author maintains that 1468 was the year when Russians first reached Bashkiria but they did not leave any imprint in the history of the region at the time. In fact, the greatest impact of the event was that Russian became aware of the peoples who lived beyond Kazan khanate.
} 
Bashkirs. ${ }^{3}$ There are a variety of objections to this assertion, raised generally by Tatar historians who claimed that Russians' arrival in the region had devastating effects for the Bashkir groups. These historians argue that there was a problem in the so-called "Bashkirs' voluntary incorporation" into the Russian empire since there were only three Bashkir elders who bowed before Ivan the Terrible.

Also Bashkir lands were so vast ${ }^{4}$ that in 1557 Russians could only show their presence in the western parts of Bashkiria while eastern Bashkiria remained under the Siberian Khanate until its destruction by Russians at the end of the century. ${ }^{5}$ Quite naturally, only the westernmost Bashkir groups yielded to this new power while the rest of the Bashkir tribes to the east and southeast did not hurry to recognize the new masters. Bashkir historian R. N. Zinurov, in a controversial work, maintained that there was a bitter five year-long war between Russians and Bashkir tribes which forced the 'white padishah'(Tsar) to send them a deputation. ${ }^{6}$ The same revisionist historian in another work maintains that the value of the charter granted by the Russian tsar was insignificant because the Tsar in no way felt himself compelled to promise anything to eastern 'savages' since they were judicially unequal. ${ }^{7}$ Zinurov is definitely not alone

\footnotetext{
${ }^{3}$ Nazir Kulbakhtin "Nachalo. Ivan Groznyi i Bashkiry” Panorama Bashkortostana, 34 (Mart, 2008): 34; Nazir Kulbakhtin "Zhalovannye Gramoty Ivana Groznogo Bashkiram” Vatandash (Sentiabr, 2007); R. G. Kuzeev, "Dobrovol'noe Prisoedinenie Bashkirii k Russkomu Gosudarstvu: Povorotnyi Punkt v Istorii Kraia" in Istoricheskoe Znachenie Dobrovol'nogo Prisoedineniia Bashkirii k Russkomu Gosudarstvu: Materialy Nauchnoi Konferentsii, ed. R. G. Kuzeev, (Ufa: Bashkirskoe Knizhnoe Izdatel'stvo, 1982), 06 - 25; A. N. Usmanov, Prisoedinenie Bashkirii k Russkomu Gosudartsvu (Ufa: Bashkirskoe Knizhnoe Izdatel'stvo, 1960), 136-137

${ }^{4}$ Historical Bashkir lands included all parts of contemporary Bashkortostan Autonomous Republic, Orenburg and Cheliabinsk oblasts and partially Samara, Kurgan, Perm, Ekaterinburg, Saratov oblasts and also eastern parts of Tatar Autonomous Republic, some parts of Uralsk oblast of Kazakhstan. See I. G. Akmanov, Za Pravdivoe Osveshchenie Istorii Narodov (Ufa: Kitap, 1995), 18.

${ }^{5}$ Vakhit Imamov, Zapriatannaia Istoriia Tatar: Natsional'no-Osvoboditel'naia Bor'ba Tatarskogo Naroda v 16-18 Vekakh za Sozdanie Nezavisimogo Gosudarstvo (Naberezhnye Chelny: Gazetno-Knizhnoe Izd-vo, 1994), 8; In the same context a number of Russian historians also claim that Bashkiria was conquered see; Sh. I. Tipeev, Ocherki po Istorii Bashkirii (Ufa: Bashkirskoe gos. izd-vo, 1930), 20-21; V. I. Filonenko, "Bashkiry, Poddanstvo Bashkir Rossii. Bashkirskie Predaniia i Istoricheskie Svedeniia ob Etom Poddanstve" Vestnik Orenburgskogo Uchebnogo Korpusa, Otdel 3, No. 7-8, Ufa, (1913): 226.

${ }^{6}$ R. N. Zinurov, Bashkirskie Vosstaniia i Indeiskie Voiny: Fenomen v Mirovoi Istorii (Ufa: Gilem, 2001), 48-58

${ }^{7}$ R. N. Zinurov, "Istoricheskie Paralleli Nachala Kolonizatsii Bashkortostana i Severnoi Ameriki” Iadkiar, 2 (1999)
} 
in his assertions about the bloody nature of Bashkir incorporation to the Russian Empire. D. Zh. Valeev argues that Bashkirs did not recognize Russian authority instantly and peacefully, and asks that if Bashkirs had accepted Russian authority willingly how could one explain a twohundred year-long Russo-Bashkir war? ${ }^{8}$ The first massive Bashkir rebellion, however, started in 1662, a century after the incorporation, when the Russian policies in the region created conditions that harmed the traditional nomadic economy and nomadic social structure, a fact which Tatar historians tend to overlook.

In the 1990 s and early 2000 s there emerged alternative interpretations that stressed another version of the nature of Bashkir incorporation into the Russian Empire. N. A. Mazhitov and A. Sultanov define this process as "compulsory-voluntary." In their opinion the Tsar's treatment of Bashkir envoys indicated the coercive nature of the Russian assimilation of Bashkiria. The process could also be interpreted as an ultimatum because the severe winter conditions claimed lives of many Bashkirs and their livestock which made them vulnerable. ${ }^{9}$ D. A. Safonov, like Madzhitov and Sultanov, argued that Bashkirs surely did not rush to the arms of Russia but had to do this due to the apparent threat of Russian aggression. This so-called voluntariness not only saved the lives of Bashkirs but also brought a series of concessions to them. $^{10}$

One last interpretation from the extensive Russian literature on the initial Russian contact with the Bashkirs is quite interesting from the semantic point of view. Zufar Enikeev argues

\footnotetext{
${ }^{8}$ D. Zh. Valeev, Istoriia Bashkirskoi Filosofii i Obshchestvenno-Politicheskoi Mysli: Osnovnye Tendentsii Razvitiia (Ufa: Kitap, 2001), 52-53.

${ }^{9}$ N. A. Mazhitov and A. N. Sultanova, Istoriia Bashkortostana s Drevneishikh Vremen do 16 Veka (Ufa: Kitap, 1994), 335-339; See also a collection of Bashkir genealogy in R. G. Kuzeev, Bashkirskie Shezhere (Ufa: Bashkirskoe Knizhnoe Izdatel'stvo, 1960), 32-33.

${ }^{10}$ D. A. Safonov, Nachalo Orenburgskoi Istorii (Sozdanie Orenburgskoi Gubernii v Seredine 18 v.) (Orenburg, 2003), 11 available at http://kraeved.opck.org/biblioteka/kraevedenie/nachalo_orenburgskoi_istorii/nachalo_oren burgskoi_istorii.exe accessed on 14 May 2008.
} 
against the Russian word prisoedinenie (annexation), claiming that this term is a tendentious and Eurocentric word which implies a one-sided act, an acquisition by the Russian government. In fact the Russian presence in the Bashkir lands became possible only after the Bashkirs received client status. So the correct term for this occurrence is the Russian entry. However, he maintains that, in the final analysis whether there was an entry or annexation by the Russians, it was a conquest in appearance. ${ }^{11}$

\section{Russians as patrons of Bashkirs}

Ivan IV, the Tsar at the time of the first contact with the Bashkirs, first of all guaranteed Bashkirs a normal, quiet life, and protection against the claims of their former masters, and from intrusions of other nomadic groups. Second, the government gave a serious concession to the Bashkirs on the land question. Bashkirs not only had the right to keep the lands that they already occupied, but also received votchina rights on their lands. These land rights combined elements of private property and entail. ${ }^{12}$ Votchina lands could be redeemed by any member of the clan or tribe for up to 40 years after it was alienation and thereby prevented the land's commoditization. ${ }^{13}$ Thirdly, the Russian government promised not to attempt to proselytize

\footnotetext{
${ }^{11}$ Zufar Enikeev, Pravovoi Status Bashkortostana v Sostave Rossii, Istoriko-Pravovoe Issledovanie (Ufa: Gilem, 2002), 47.

${ }^{12}$ Richard Hellie, "The Expanding Role of the State in Russia" in Modernizing Muscovy; Reform and Social Change in Seventeenth-Century Russia, ed., Jarmo T. Kotilaine, \& Marshall Poe, (London: Routledge, 2004), 42-43.

${ }^{13}$ A prominent Russian scholar of Bashkir history, A. P. Chuloshnikov, argues that there was not any common document relating to votchina rights of Bashkirs granted by Ivan IV because it never existed. A. P. Chuloshnikov, "Feodal'nye Otnosheniia v Bashkirii i Bashkirskie Vosstaniia 17 i Pervoi Poloviny 18 vv." in Materialy po Istorii Bashkirskoi Istorii, part 1, Bashkirskie Vosstaniia v 17 i Pervoi Polovine 18 vv. (Moskva\&Leningrad: Izdatel'stvo Akademii Nauk SSSR, 1936), 23 However, he overlooks the fact that there was not a common grant for all Bashkirs. Bashkir tribal leaders only separately visited Russian Tsar and officials and they received their grants individually. The separate grant of votchina right to the first Bashkir tribe created a snowball effect among other Bashkir tribes and persuaded them that reasonable terms of votchina rights granted by the Tsar would be preferable to those of the Nogais' or Sibir Khans' terms who demanded exorbitant Iasak payments. See for the details B. A. Aznabaev, Integratsiia Bashkirii v Administrativnuiu Strukturu Rossiiskogo Gosudarstva (Vtoraia Polovina 16-Pervaia Treti 18 vv.), (Ufa: RIO BashGU, 2005), 26; The author relied on Pol'noe Sobranie Russkoi Letopisei. v.13, part 1, (1907), 248.
} 
Muslim Bashkirs, a promise which sharply contrasted with how Russians treated the conquered Kazan Tatars. Such a promise, on the other hand, can be interpreted as Russians' lack of a definite proselytization policy among Muslims. Fourthly, the government avowed to not interfere in the internal life of the Bashkir population. The local authority was left in the hands of Bashkir nobles. ${ }^{14}$

These were generous terms from the Bashkirs' standpoint. There could be two possible practical reasons for this Russian generosity. In the frontier areas the hold of a central government, either Russian or any other government, was most of the time tenuous. Since centrifugal tendencies are always strong among indigenous populations, weak government authority made it relatively easy for these peoples to switch sides and look for alternative patrons. Accordingly rulers were only rarely willing to take risks to impose their will on the peoples of the frontier. ${ }^{15}$ The majority of the Bashkirs when Russians took over the Kazan khanate in 1552 were living under Nogai khanate, another rival of Russia. Russian authorities calculated that if they imposed too harsh terms on the Bashkirs of the former Kazan khanate, this could lead to an exodus of Bashkirs away from Russian control. These Bashkirs would go south and southeast to join with the other Bashkirs to form a group resisting against Russia's further advance into the region. Russian imposition of harsh terms could also discourage those Bashkirs who were at the time beyond their territory from accepting Russian suzerainty. It was a grave necessity for the Russians to attract other groups of Bashkirs to their side. Their cautious policy in an unstable frontier soon bore fruit as a large envoy of Min, one of the most populous Bashkir

\footnotetext{
${ }^{14}$ I. G. Akmanov, Chelobitnaia Bashkir Ufimskoi Provintsii na Imia Imperatritsy Rossii Anny Ivanovny s Svoikh Nuzhdakh ot 1733 g." Vatandash, 6, (2005)

${ }^{15}$ For a deeper analysis of the methods of frontier control see Daniel Power, “A. Frontiers: Terms, Concepts and the Historians of Medieval and Early Modern Europe" in Frontiers in Question; Eurasian Borderlands, 700-1700, ed. Daniel Power and Naomi Standen, (London: Mc Millan Press, 1999), 22.
} 
tribes, arrived in Moscow in 1554 to apply for Russian suzerainty. They expected the same privileges granted to other Bashkir tribes earlier and then they abandoned their Nogai masters. ${ }^{16}$ As for votchina rights, traditionally the Russian Tsar considered land as his patrimony that he inherited from his ancestors. Even after the recovery of old Kievan lands and new military conquests in the areas that had never been a part of old Kiev, Russian tsars continued to consider all these lands as their own property. Richard Pipes described this pattern as a Russian patrimonial system: "Once an area had been annexed to Moscow, whether or not it had ever formed part of Kiev, and whatever the ethnic and religious affiliation of its indigenous population, it immediately joined the 'patrimony' of the ruling house, and all succeeding monarchs treated it as a sacred trust which was not under any circumstances to be given up."17 Unlike Pipes' negative stance about Russian patrimonialism, such a system was not uniquely Russian. Other western European colonial empires widely relied on such a system as well. The patrimonial system was an effective administrative method for the European colonial empires which lacked enough personnel and left the local politics to the indigenous collaborative agents and thereby effectively continued their rule with minimal use of force. ${ }^{18}$

Such a land system was protective of the existing social structure and preventive of radical changes and social upheaval since changes take place in the long run and very slowly. Direct rule on the other hand required a high number of competent officials who would be able to impose the will of the central authority and construct a centralized administration which would

\footnotetext{
${ }^{16}$ A. N. Usmanov, Dobrovol'noe Prisoedinenie Bashkirii k Russkomu Gosudarstvu (Ufa: Bashkirskoe Knizhnoe Izdatel'stvo, 1982), 139.

${ }^{17}$ Richard Pipes, Russia under the Old Regime (New York: Charles Scribner's Sons, 1974), 79; see also S. Bekbulatov, "Bashkirskie Vostaniia i Tatary" Vestnik Nauchnogo Obshchestva Tatarovedeniia 9-10 (1930): 67; Bekbulatov argues that the land of all invordotsev (other faiths) having entered into the Muscovite Service was considered the property of the Velikogo Gsodaria. (Great Lord); For the patrimonial nature of Muscovite politics see Nancy Shields Kollmann, "Muscovite Patrimonialism" in Major Problems in the History of Imperial Russia, ed. James Cracraft, (Lexington, Massachussets: D. C. Heath, 1994), 37-46

${ }^{18}$ Matthew Lange, Lineages of Despotism and Development: British Colonialism and State Power, (Chicago: University of Chicago Press, 2009), 25
} 
require the dismantling of the existing indigenous institutions. Such a system was both transformative and intensive. ${ }^{19}$ It would endanger the indigenous social system and cause the destruction of a whole community. Unlike Richard Pipes' derogatory remarks, the votchina system was a quite favorable system for the Bashkir groups which were not in a position to deal with the risks of radical and abrupt transformations.

The history of Bashkirs under Russians, until mid-1700s when Russians firmly brought Bashkir lands under their control, revolved around the question of who really owned the land in Bashkiria. It was the main reason for all the Bashkir rebellions that haunted the region until Pugachev rebellion. A number of imperial Russian historians argued that the Russian government had assigned the Bashkirs votchina rights but never made its point clear precisely about the ultimate land ownership. ${ }^{20}$ There are however hints about the ultimate landownership. V. N. Vitevskii comments that Bashkirs lost their rights to sell the land to other persons; they could only give the land as "quitrent no more than two years to other Bashkirs but to rent or sell the land to other inorodets (other faiths) or Russians was strictly prohibited." ${ }^{21}$

The Muscovite Law Code (Ulozhenie) of 1649 states that "Boyars, and okol'nichie, and counselors, and stol'niki, and striapchie, and Moscow dvoriane, and provincial dvoriane and deti boiarskie, and Russians of all ranks shall not buy or exchange service [lands] or any [other] lands, and sha1l not take [land] on mortgage, and [as] grants, and on hire for many years [in any transactions] in the provincial towns with princes, and with mirzas, and with Tatars, and with

\footnotetext{
${ }^{19}$ Matthew Lange, Lineages of Despotism and Development: British Colonialism and State Power, (Chicago: University of Chicago Press, 2009), 4

${ }^{20}$ I. Zhukovskii, Kratkoe Obozrenie Dostopamiatnykh Sobytii Orenburgskogo Kraia, Rospolozhennykh s 1246 po 1832 God Chinovnikom, Sostoiashchim pri Orenburgskom Voennym Gubernatore po Osobym Porucheniiam, (1832), 3-5; I. Debu, Topograficheskoe i Statisticheskoe Opisanie Orenburgskoi Gubernii v Nyneshnem eia Sostoianii, (1837), 35-170; N. V. Popov, Tatishchev i ego Vremia, (1861); A. V. D. "O Bashkirakh" Orenburgskoe Gubernskie Vedomosti, 41 (1863): 230.

${ }^{21}$ V. N. Vitevskii, I. N. Nepliuev i Orenburgskii Krai v Prezhnem Ego Sostave do 1758 g. (Kazan, 1897), 391.
} 
Mordovians, and with Chuvashes, and with Cherernises, and with Votiaks, and with Bashkirs." 22 The Code of 1649 is a genuine example of patrimonial codification which substantially regulated every estate and the relations among them and their relations with the state. In the final analysis the articles of this vast codification relating to the Bashkir lands that forbade their sale was an attempt by the central authority to protect Bashkir lands from the rapacious speculators. This kind of patrimonial codification often promotes the security of all social elements. ${ }^{23}$

Even if Russian Tsars saw themselves as the ultimate owners of the Bashkir lands, Bashkirs did not share this view. Both sides had their own legitimate reasons to push their claims forward. It should be borne in mind that a patron and a client are not on equal status. In their relationship there is a certain disparity with respect to their wealth, power and status. A patron has the capabilities and responsibilities in times of need to supply goods and services to the client who needs them for his own survival and well-being. ${ }^{24}$ But this delivery of supplies does not make the patron all-powerful over the client. Although he could issue commands, the patron also has some reciprocal responsibilities.

This relationship is not a formal and impersonal one where the boundaries of the relationship are clearly defined. ${ }^{25}$ Such a patron-client relationship corresponds closely to the relationship between Bashkirs and Russian authorities at the very beginning of the formation of this patron-client relationship. The fact that Russian rulers lacked means to impose direct rule in the distant Bashkir lands led them to recognize Bashkirs' autonomy, but the existing social

\footnotetext{
${ }^{22}$ Richard Hellie, trans., The Muscovite Law Code (Ulozhenie) of 1649 Part 1 (Irvine, California: Charles Schlacks jr., 1988), 112.

${ }^{23}$ Jarmo T. Kotilaine \& Marshall Poe, ed., Modernizing Muscovy: Reform and Social Change in SeventeenthCentury Russia, (London and New York:Routledge Curzon,2004), 77

${ }^{24}$ P. Blau, Exchange and Power in Social Life (New York: J. Wiley, 1964), 21-25.

${ }^{25}$ James Scott, "Patronage or Exploitation," in Patrons and Clients in Mediterranean Societies, ed. Ernest Gellner and John Waterbury, (London: Duckworth, 1977), 22. It must be mentioned that the author in his article argues about patron-client relationship in a sedentary society. In any case, some useful analogies can be constructed in the Russo-Bashkir case.
} 
dynamics of the Muscovite Russia had the potential to endanger tranquility in Bashkiria. The most sensitive issue for Bashkirs was the protection of their lands from being seized by those who escaped from the Russian state's repressive measures. The Muscovite authorities had a bifurcated dilemma in Bashkiria. They were interested in the steady flow of Iasak payments and the tranquility of the region but on the other hand they were short of competent administrators and were unable to stop the migration of other national groups to the region and their seizure of Bashkir lands. The more Russian authorities failed to prevent the mass migration of people from the central areas of Russia and from the middle Volga region, the more tensions increased in Bashkiria. Under such conditions the Muscovite rulers had no other alternative but to decree that Bashkir lands were close to colonization and in this context they almost always confirmed Bashkirs' votchina rights. ${ }^{26}$

The outstanding Russian historian of the region in the nineteenth century, N. V. Firsov, contended that the ultimate owner of the all the lands not only in Bashkiria but throughout Russia was the tsar. He further noted that the sovereign considered himself complete owner of the lands of Kazan, Astrakhan, the Nogai lands, Perm and Siberia. And the sovereign gave this land to whomever he wanted and under whatever conditions he redeemed necessary. While doing this, he never asked for the consent of the original owners of the land. ${ }^{27}$ This ambiguous situation was the most troublesome problem for both parties. Muscovite rulers did not feel themselves in a strong position in its relation to Bashkirs and never made clear their intentions of encroachment

\footnotetext{
${ }^{26}$ A. Z. Asfandiiarov explains that Tsarism was interested in the development of natural riches of the region. Therefore it aspired to limit Votchina rights of Bashkir volosts. He also maintains that Russian authorities failed in this respect, leaving Bashkirs no other alternative but to start a desperate war against Tsarizm. See A. Z. Asfandiiarov, Bashkiriia posle Vkhozhdeniia v Sostav Rossii (Vtoraia Polovina 16 - Pervaia Polovina 19 v.), (Ufa: Kitap, 2006), 25; A. Z. Asfandiiarov, "Eshche Raz o Kharaktere Prisoedineniia Bashkortostana k Rossii" (Pervye Validovskie Chtenie; Mezhdunarodnaia Nauchnaia Konferentsiia. Vostokovedeniia v Bashkortostane: Istoriia. Kul'tura. 3., Ufa, 22-24 Centiabria 1992 Goda), 9-10.

${ }^{27}$ N. A. Firsov, "Polozhenie Inorodtsev v Moskovskom Gosudarstve" Uchenye Zapiski Kazanskogo Universiteta $v$. 2, (Kazan', 1866), 9.
} 
in Bashkiria in order better to exploit the riches of the region and take greater advantage of its strategic location. Still, the local conditions made their officials adopt a gradual land seizure policy without inciting Bashkir restlessness until the reign of Peter the Great.

In 1557, Bashkiria was a too great morsel for the Russians to swallow at one time as their lands extended from Middle Volga in the west to Tobol River in the east, some 33 million desiatinas. ${ }^{28}$ While the westernmost Bashkirs recognized Russian suzerainty in 1550 s, those groups to the east only gradually entered into the sphere of Russian influence when the so-called unification of Bashkirs under Russians was complete. In the 1620s the easternmost Bashkir groups - Kara and Baryn Tabyn, Synrian- accepted Russian suzerainty after the fall of the Siberian Khanate. ${ }^{29}$

\section{Initial Russian Administrative policies}

The best possible way for the Russians to absorb Bashkir lands or to have a façade of Russian administration in the region was to delineate Bashkir territory in terms of the tribal composition of those lands and proximity of them to the center. Not surprisingly one of the very first acts of the Russian authorities in the region was to preserve four dorogas, administrative-

\footnotetext{
${ }^{28}$ A. I. Akmanov, Zemel'naia Politika Tsarskogo Pravitel'stva v Bashkirii (Vtoraia Polovina 16-Nachalo 20 vv.) (Kitap: Ufa, 2000). 9: Other historians of Bashkiria give approximate estimations about the size of historical Bashkir lands. A.Z. Asfandiiarov relying on the figures of General Land Survey (he does not explain which one) claims that historical Bashkiria was as large as 39-40 Million desiatinas. But this amount declined to 17 Million desiatinas by 1832 due to the land seizures by the government for the purpose of constructing factories, fortresses, distribution of other parts to Russian nobles, monasteries etc. Finally, Bashkirs lands were as small as 7 million desiatinas by 1917. A. Z. Asfandiiarov, Bashkiriia posle Vkhozhdeniia v Sostav Rossii (Vtoraia Polovina 16 - Pervaia Polovina 19 v.) (Ufa: Kitap, 2006), 72: For N. F. Demidova it was 30 Million desiatinas. N. F. Demidova, "Zemlevladenie i Zemlepol'zovanie v Ufimskom Uezde v 16-17 vv." Ezhegodnik po Agrarnoi Istorii Vostochnoi Evropy, (Minsk, 1964), 265.; For N. M. Kulbakhtin. It was over 35 Million desiatinas or around 336.000 km². See; N. M. Kulbakhtin, Gornozavodskaia Promyshlennost v Bashkortostane 18 Vek, (Ufa: Kitap, 2000), 27.

${ }^{29}$ A. I. Akmanov, Zemel'nye Otnosheniia v Bashkortostane i Bahkirskoe Zemlevladenie vo Vtoroi Polovine 16Nachale 20 v. (Ufa: Kitap, 2007), 73.
} 
territorial divisions which had been created earlier by the Golden Horde. ${ }^{30}$ The preservation of these by the Russians could be understood as the Russian attempt not to overthrow the previous system and to provide an orderly flow of Iasak payments to the Russian treasury. The dorogi became a central theme in the Russian administration of the region. The four dorogi - Kazan, Osin, Sibir and Nogai - were further divided into volosts, a total of 75 in Bashkiria by the 1730s. ${ }^{31}$ Even though this administrative division in the form of dorogas helped the Russians to better grasp the features of the region, the Bashkir groups did not have any sense of these divisions. As nomads, they had no use of these divisions and crisscrossed those imagined lines whenever they needed to. ${ }^{32}$

\footnotetext{
${ }^{30}$ R. G. Bukanova, Goroda i Gorodskoe Naselenie Bashkirii v 16-17 vv. (Ufa: Bashgosuniversitet, 1993), 22: The nineteenth century Russian regional historian N. V. Vitevskii claims that these administrative units were created by the Russian authorities soon after the construction of Ufa in 1586. N. V. Vitevskii, Nepliuev i Orenburgskii Krai v Prezhnem ego Sostave do 1758 g. Part 1 (Kazan: 1891), 105.

${ }^{31}$ Materialy po Istorii Bashkirskoi Istorii, part 1,: Bashkirskie Vosstaniia v 17 i Pervoi Polovine $18 v v$. (Moskva\&Leningrad: Izdatel'stvo Akademii Nauk SSSR, 1936), 135-138 and 140-144; the burgomaster of Kungursk, Iukhnev, reports that the total number of volosts in 1726 was sixty. These varying numbers suggest that Russian authorities did not have a specific record keeping about the volosts.

${ }^{32}$ These administrative units were extinct by the end of the eighteenth century. The exact date of their extinction is a matter of debate but primary documents compiled in Materialy po Istorii Bashkirskoi ASSR give us clue that they were still available as late as 1793 as we see from the correspondence between Tsarina Catherine II and governorgeneral of Ufa. Materialy po Istorii Bashkirskoi ASSR. Volume 5, (Moskva, Izdatel'stvo Akademii Nauk, 1960), 567. But they were certainly abolished with the foundation of Cantonal system in Bashkiria in 1798. A. Z. Asfandiiarov, Bashkiriia posle Vkhozhdeniia v Sostav Rossii (Vtoraia Polovina 16 - Pervaia Polovina 19 v.) (Ufa: Kitap, 2006), 110.
} 


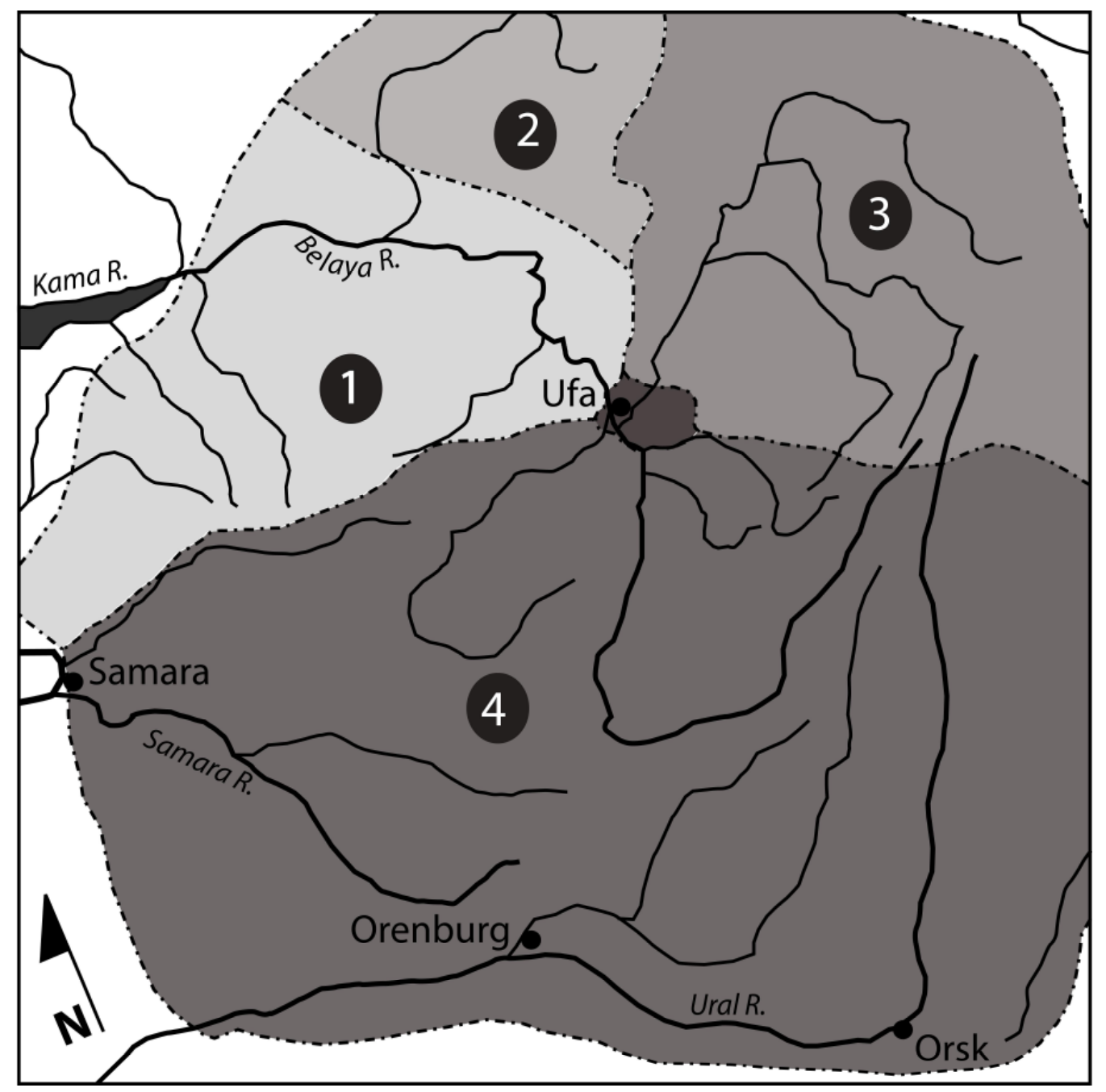

Bashkir Dorogas (Oblasts): 1. Kazan. 2. Osin. 3. Sibir. 4. Nogai. ${ }^{33}$

Ivan the Terrible's grant of clientage to the Bashkirs was a remarkable event and the

Bashkirs were the only group within Russia to receive such a status. It is therefore not surprising that the Bashkirs' patrimonial rights were legally formalized first by Ivan the Terrible. ${ }^{34}$ In the following decades, this grant was reaffirmed several times as evidenced by the Imperial mandate

\footnotetext{
${ }^{33}$ The map is available at http://www.bashedu.ru/encikl/ddd/dorogi.htm .

${ }^{34} \mathrm{~N}$. V. Firsov makes a comparison between Bashkirs and those Tatars of former Kazan khanate and maintains that no other indigenous had more privileges than Bashkirs with so few obligations like paying a meager Iasak than paid by the other subject peoples. N. A. Firsov, Inorodcheskoe Naselenie Prezhnego Kazanskogo Tsarstva v Novoi Rossii do 1762 Goda i Kolonizatsiia Zakamskikh Zemel'v Eto Vremia.Vol.6, (Kazan: 1871), 21.
} 
from the voevod in Ufa in 1664, and government decrees of 1632, 1654, 1694, 1734, 1739, 1755, 1790 and later years. ${ }^{35}$ The decrees that guaranteed the Bashkirs' votchina rights and the authorities' policies to centralize administration may seem contradictory. What the government did was to ensure that Bashkir lands were kept as tribal votchina but as time passed on the number of migrants increased and the amount of Bashkir lands diminished. Still, those remaining parts of Bashkir lands were, against all odds, conceived as Bashkir votchina lands.

Bashkiria was at the fringe of the Muscovite Russia, a genuine border area. An analogy can be established in this respect between Russia's Bashkir frontier and the Roman Empire's frontiers. "Because they (frontier areas) are ethnically and culturally different from the interior provinces, the frontier zones offered peculiar challenges to imperial ingenuity."36 Thus, this grant was not without reasons. Ernest Gellner argues that "a state may have partial control of outlying geographical areas and find it uneconomic to assert itself in them. It may then hand over power in them to individuals who ... possess a local power base and who mediate between central requirement and local interests." ${ }^{, 37}$ In light of this statement it can be argued that this Russian resilience in the face of newly added territories and subjects, however nominally controlled, reflected an intention to avoid alienating the indigenous population. Imposing a new system could elicit an unexpected reaction by the local population and endanger Russians' unsubstantial presence in the region. To draw a low profile for the time being seemed the best alternative.

\footnotetext{
35 M. V. Murzabulatov, "O Bashkirakh-Votchinnikakh” in Askinskii Raion; Natsionalnyi Sostav Naselennykh Punktov po Perepisiam 18-20 Vekov,ed., K. A. Aralbaev, (Ufa: 2002), 23.

36 John W. Eadie, "Civitates and Clients: Roman Frontier Policies in Pannonia and Mauretania Tingitana" in The Frontier: Comparative Studies ed. David H. Miller and Jerome O. Steffen, (Norman: University of Oklahoma Press, 1977), 58.

${ }^{37}$ Ernest Gellner, "Patrons and Clients" in Patrons and Clients in Mediterranean Societies ed., Ernest Gellner and John Waterbury, (London: Duckworth, 1977), 4.
} 


\section{Bashkir society in the late $16^{\text {th }}$-early $17^{\text {th }}$ Centuries}

The Bashkirs, unlike their former masters, the Kazan Khanate, did not have a single center and a single leadership. On the contrary their lands at the time of Russians' appearance in the region had been under a number of Khanates: the Sibir Khanate in the eastern part of Bashkir territory, the Nogay Khanate in the southeast and the Astrakhan Khanate in the south and southwest. On the other hand Bashkirs were organized into at least thirty tribes, each led by a number of notables, divided into many more clans with many local leaders such as beis ${ }^{38}$ and murzas. ${ }^{39}$ The relations between these tribes were far from friendly because of the competition and frictions over pasturelands. ${ }^{40}$ Under such conditions in the region the best way for the Russians to save face was to grant client status to the Bashkirs and let them handle their own affairs themselves. To interfere with local institutions and practices could only harm Russia's prestige among the peoples of the region, which they had gained after the conquest of Kazan. The dilemma of the intruder was that the military means were good enough to defeat armed resistance, but they were a dismal failure in consolidating Russian rule effectively. Russia lacked the means necessary to execute central government objectives beyond collecting Iasak.

A minority of the Bashkir groups, especially those who lived in areas near former Kazan khanate, were sedentary or semi-nomadic. The rest of the Bashkir groups migrated between pasturelands. This nomadic aspect of Bashkir life created serious problems for the Bashkirs since they encountered a sedentary culture after the 1550s, Russia, whose demands for fields clashed with Bashkir demands for meadows. ${ }^{41}$

\footnotetext{
${ }^{38}$ Bey (beg, bei) is one of the oldest Turkic titles which roughly means seigneur. It was mentioned in the Turkic Orkhon inscriptions in the 730s.

${ }^{39}$ Murza (mirza) is an Old Persian title used for princes.

${ }^{40}$ R. Z. Ianguzin, and F. G. Khisamutdinova, Korennye Narody Rossii; Bashkiry, (Ufa: Kitap, 2007), 37-81.

${ }^{41}$ In the semi-nomadic type of economy, the livestock owners have their permanent settlements. They have their agricultural fields where they grow grain but they also maintain their livestock as supplementary source of food or income. In this type of economy seasonal migrations take place within short distances for short periods of time.
} 
One other radical difference between nomadic and sedentary societies was that nomadic Bashkirs did not have a system of private property in land. ${ }^{42}$ Carving out lands, declaring them privately owned, and prohibition of the free passage of nomads through these lands seemed the strangest practices to the Bashkirs. Bashkirs owned the land communally but operated on these lands individually. Each member of the Bashkir community had the right to use land but cattle were owned individually. Such practices were the most useful for a nomadic or semi-nomadic society and the Bashkirs resisted Russian attempts in the seventeenth and eighteenth centuries to turn pastures into privately owned fields. ${ }^{43}$ Though Russians had promised to preserve the Bashkirs' socio-economic structure, their civilization operated at a different level and they were in the long run unwilling to preserve this system because a property system would be better many reasons. Since these two cultures were intolerably alien, whatever the Russians did would seem like appropriation to the Bashkirs.

The traditional form of life of Bashkirs changed very slowly, and the development of a sedentary life among these nomads was a difficult process. In this context, Imperial and Soviet period historians, with some exceptions, always preferred to view Russian conquest of the region as a progressive move. They claimed that Bashkirs were living in a nomadic hunter-gatherer historical stage while the Russians were at a much more advanced form of life because they were sedentary and agrarian and brought true forms of sedentary life to Bashkir lands and thereby transformed them.

Such type of economy was available throughout the steppe areas by the seventeenth century, especially in those areas where there were urban centers like the cities of Maveraunnahr of Central Asia. See; Anatoly M. Khazanov, "Nomads and Oases in Central Asia" in Transition to Modernity: Essays on Power, Wealth, and Belief, ed. Ernest Gellner, John A. Hall, Ian Charles Jarvie,(New York: Cambridge University Press, 1992), 71.

${ }^{42}$ This system was not unique to Bashkirs. All other nomadic societies had such a system. For greater detail see, A. M. Khazanov, Nomads and the Outside World, (Cambridge: Cambridge University Press, 1984)

${ }^{43}$ A. I. Akmanov, Zemel'nye Otnosheniia v Bashkortostane i Bahkirskoe Zemlevladenie vo Vtoroi Polovine 16Nachale 20 v. (Ufa: Kitap, 2007), 80. 
This argument must be taken with some skepticism because Bashkir society had shown the first obvious signs of the development of a sedentary society under their Tatar-Mongol suzerains by the late 1400 s. There was an increasing tendency among the Bashkirs to embrace some aspects of sedentary life especially in the wooded and mountainous areas ill-suited to nomadism. Other developments tending toward sedentarism included the growing preference of the cattle-raising as opposed to camel herds of the steppe region, emergence of beekeeping and metal workmanship, privately owned livestock, and the growing feudalization of Bashkir society who had been granted patrimonial rights by their suzerains. ${ }^{44}$ Bashkirs in the northwest region of Bashkiria, vassals of the former Kazan Khanate, had already passed to the stage of agriculture. ${ }^{45}$ A Russian official from the Kungur district, Osin doroga, in northern Bashkiria wrote that "Bashkirs of the region (Osin doroga) mostly grow grain, never leave their region for steppe region for their herds. In fact they live like Russian peasants. Their herd is not large but they cut a lot of hay for spring to feed their animals." ${ }^{, 46}$ It could be assumed that even without Russian interference, which ultimately cost the Bashkirs two hundred years of warfare and material and human loss, Bashkirs would have developed a sedentary agricultural life anyway. ${ }^{47}$

The Bashkirs and the Russians were so radically different that a compromise was reached only at the cost of granting them autonomy by the Russian tsar. The Russian authorities' first consternation was caused by Bashkirs' lack of any plausible political organization, which prevented Russians from establishing a reasonable vassal-lord relation in the area. Conversely,

\footnotetext{
${ }^{44}$ B. Kh. Iuldashbaev, Istoriia Formirovaniia Bashkirskoi Natsii Dooktiabrskoi Period, (Ufa: Bashkirskoe Knizhnoe Izdatel'stvo, 1972), 86.

${ }^{45}$ R. Z. Ianguzin, and F. G. Khisamutdinova, Korennye Narody Rossii; Bashkiry, (Ufa: Kitap, 2007), 107.

${ }^{46}$ Materialy po Istorii Bashkirskoi ASSR, v. 3, (Moskva \& Leningrad: Izdatel'stvo Akademii Nauk, 1949), 487.

${ }^{47}$ This assumption can be boosted with further references from R. M. Raimov or S. I. Rudenko. They argue that Bashkirs as late as the early 1900s had preserved their semi-nomadic / nomadic mode of life. S. I. Rudenko, Bashkiry: Istoriko - Etnograficheskie Ocherki (Moskva \& Leningrad: Izdatel'stvo Akademii Nauk SSSR:, 1955), 64; R. M. Raimov, 1905 God v Bashkirii: Revoliutsionnoe Dvizhenie v 1905-1907 gg. (Moskva \& Leningrad: Izdatel'stvo Akademii Nauk SSSR, 1941), 13.
} 
Russians had to deal with so many different Bashkir groups and demands that the only solution for them momentarily was to leave Bashkirs alone until the time they could figure out a workable solution to the issue. Nomadic, nominally Muslim, tribal Bashkirs were to create within a century great troubles for the sedentary, centralized, Christian Russian state. The radical differences in the mindsets of both groups caused countless misunderstandings that created a fruitful backdrop for armed clashes. The Bashkir case was an extremely important encounter of Muscovite Russians with a fully nomadic society whose centrifugal tendencies had to be restrained in one way or another. The Russians had no idea about how to achieve this and they showed considerable confusion.

The first evidence of this confusion that took place was the grant of votchinnoe pravo by the Russian tsar to some of the Bashkir tribal leaders soon after the nominal Russian incorporation of the Bashkir lands. When Russians granted autonomy and a land charter to Bashkirs, they thought it was a favor to Bashkirs and its status would be permanent. From the Bashkir point of view, these grants were only temporary and they believed Russians were no different than their previous masters, Kazan or Sibir khans or Nogais. This meant to them that Bashkirs were the unquestionable masters of their own lands as long as they paid their yearly tribute (Iasak). Despite counterarguments by some of the historians that the Bashkirs were militarily crushed by Russians and forced to recognize Russians as new lords ${ }^{48}$, it seems clear that the Bashkirs accepted the Russians as their new lords without too much fuss, considering the military might of Russians which destroyed their former masters without a major difficulty.

\footnotetext{
${ }^{48}$ V. N. Vitevskii, I. I. Nepliuev i Orenburgskii krai 2 volumes, (Kazan: 1897); V. I. Filonenko, "Bashkiry" Vestnik Orenburgskogo Uchebnogo Okruga, Section 3, No. 7-8, (Ufa: 1913), 225-226.; Sh. I. Tipeev, Ocherki po Istorii Bashkirii (Ufa: Bashkirskoe Gos. Izd-vo, 1930), 20-21; A. P. Chuloshnikov, "Feodal'nye Otnosheniia v Bashkirii i Bashkirskie Vosstaniia 17 i Pervoi Poloviny 18 v." Materialy po Istorii Bashkirskoi Istorii, part 1, Bashkirskie Vosstaniia v 17 i Pervoi Polovine 18 vv. (Moskva\&Leningrad: Izdatel'stvo Akademii Nauk SSSR, 1936), 23; P. Ishcherikov, Ocherki iz Istorii Kolonizatsii Bashkortostana: Ot Zavoevanii Bashkortostana do Epokhi Raskhishcheniia Bashkirskikh Zemel, (Ufa: Kitap, 2003), 8.
} 
Another motive for the Bashkir recognition of Russian protection was the tumult in the Bashkir lands under their former lords, Kazan, Sibir and Nogai khanates, and the nearly endless wars between them that almost destroyed Bashkirs' means of livelihood. The Russians seemed strong enough to put an end to those times of troubles, granting votchina to various Bashkir tribes stating "Let no one run, let each remain in his own faith in compliance with his customs."49 This declaration is evidence that not only were the Russians not exclusively brutal exploiters, but the subject peoples had an interest in accepting some degree of Russian domination for their own goals.

The Russian authorities left the local affairs of the Bashkir tribes to the authority of the Bashkir elders (starshina). These starshinas had to perform a number of functions including the administration of their districts (volosts); leading national congresses, (Iighin) and popular gatherings $^{50}$; organization of the collection of tribute; military service in the capacity of the protection of Russia's southeastern frontiers; preservation of order and safety in the region and negotiation with the nearby ethnic groups like Kalmyks to stop mutual attacks into each other's territory. ${ }^{51}$ Unlike their earlier policy of converting local nobles to orthodoxy as was the case in the Kazan region, Russian authorities did not force Bashkir elites to embrace Christianity in order not to perturb the already unnerved Bashkir life in distant regions where the Russian authority was shaky.

\footnotetext{
${ }^{49}$ R. G. Kuzeev, trans., Bashkirskie Shezhere (Ufa:Bashkirskoe Knizhnoe Izdatel'stvo, 1960), 33; F. A. Ishkulov. ed., Istoriia Gosudarstva i Prava Bashkortostana Part 1 (Ufa: Kitap, 1996), 9.

${ }^{50}$ These Bashkir national gatherings used to take place at extraordinary times. The elders of the tribes come together in open air and discuss matters relating to Bashkirs in general. These were generally not universal gatherings. Some Bashkir tribes occasionally used to come together and declare lighin and discuss matters. Most of the times, these Iighins took place before a general revolt against Russians. Accordingly Russians considered such mass gatherings with utmost suspect. One of the most famous Iighins, led by Bashkir tribe, Iurmat, took place on the eve of Bashkirs' decision to accept Russian suzerainty to inform Bashkirs about their trip to Moscow to visit Belyi Shakh (Russian Tsar). R. G. Kuzeev, trans., Bashkirskie Shezhere, (Ufa: Bashkirskoe Knizhnoe Izdatel'stvo, 1960), 33.; For more details see, R. G. Kuzeev, Ocherki Istoricheskoi Etnografii Bashkir (Rodo-plemennye Organizatsii Bashkir v 17-18 vv.) (Ufa: Bashkirskoe Knizhnoe Izdatel'stvo, 1957), 87-88.

${ }^{51}$ Materialy po Istorii Bashkirskoi ASSR, v.6 (Ufa: Kitap, 2002), 370.
} 
Russians did successfully incorporate a number of Bashkir elite into the Russian service. Those leaders played later on an ominous role in the crushing of Bashkir rebellions in the 1600s and 1700s. On the other hand there was another side to this gathering. By relying on these Bashkir elite, Russian authorities were also strengthening Bashkir nobles' position in the Bashkir society and creating some sort of solid leadership among this mercurial people. Such an elite, if their material needs were not fulfilled or they were humiliated by the center, could lead their forces with the Bashkir masses, increasingly overburdened by the Iasak payments as the seventeenth century progressed, in rising against increasing Russian interference, either by the state or by individuals like colonizers, in local Bashkir affairs.

Firouzeh Mostashari argues in her book about the Northern Caucasus that as part of their colonial policy Russians endeavored to co-opt Muslim elites by distributing benefits. Thanks to such actions, the local elite were discredited in the eyes of the local population and lost their traditional social standing. ${ }^{52}$ This was partially true for the Bashkir case. When Bashkir nobles switched sides from the Russian government to the disgruntled Bashkir masses they were always more than welcome, especially because the fate of the tribe often depended on the rich elite who had the means to finance a war effort against the government. Not surprisingly the greatest Bashkir rebellions were led by wealthy Bashkir nobles.

Despite all these elements of self-government that the Russian tsars granted the Bashkirs, the conditions of Bashkirs worsened over time. Their right to the lands came up against a number of obstacles. Bashkir tribes and clans were required to have written evidence that stated their right to those lands granted by the state. Otherwise Russian authorities would declare their

\footnotetext{
${ }^{52}$ Firouzeh Mostashari, On the Religious Frontier: Tsarist Russia and Islam in the Caucasus (London: I.B. Tauris, 2006), 3 .
} 
land occupation illegal. ${ }^{53}$ On the other hand the free seasonal migrations of the Bashkirs were prevented because of a series of fortifications in the Bashkir lands. The Russians repeatedly confiscated Bashkir lands for the construction of fortresses as well as villages, settlements and factories. Unlike previous lords of the Bashkirs like the Kazan Tatars and Nogais, Russians attempted to control these new lands, at least in part. The first of a series of garrison towns was Ufa, whose foundation in 1574 admittedly upon the request by Bashkirs to facilitate the collection of Iasak, because Kazan where the Iasak payments were made was far away, and to improve Bashkir defenses against the raids of Kazakhs and Kalmyks, ${ }^{54}$ opened a new phase in the history of the region. ${ }^{55}$ Ufa gained town status in 1586 and it became the first true city in the region until the foundation of Birsk in 1663, housing a number of Tsarist officials, streltsy (musketeers) and merchants.

\section{Russian Deviations from Bashkir Votchina Rights}

The expansion of Russian authority in the region was closely tied primarily to the construction of towns in the middle of the Bashkir territories. The first of these towns, Ufa, quickly became a center of the Russians' far-reaching operations on internal and international levels. It became the place where Russians supervised the collection of tribute not only from Bashkirs but also from the surrounding regions like Perm and western Siberia. Ufa also served

\footnotetext{
${ }^{53}$ I. G. Akmanov, Bashkiriia v Sostave Rossiiskogo Gosudarstva 17-Pervoi Polovine 18 Veka (Sverdlovsk: Izdatel'stvo Ural'skogo Universiteta, 1991), 29.

${ }^{54}$ P. I. Rychkov, Topografiia Orenburgskoi Gubernii (Ufa: Kitap, 1999), 263; A. N. Usmanov, Prisoedinenie Bashkirii k Russkomu Gosudartsvu (Ufa: Bashkirskoe Knizhnoe Izdatel'stvo, 1960), 155; R. G. Bukanova, GorodaKreposti Iugo-Vostoka Rossii v 18 Veke Istoriia Stonovleniia Gorodov na Territorii Bashkirii (Ufa: Kitap, 1997), 50 .

55 Bashkirs also provided money and construction material see; D. N. Sokolov,"Opyt Razbora Odnoi Bashkirskoi Letopisi" Trudy Orenburgskoi Uchenoi Arkhivnoi Kommissii Part 4, (1898), 48.; The prominent Russian historian of $1700 \mathrm{~s}, \mathrm{~V}$. N. Tatishchev argues that as soon as Bashkirs recognized Russian suzerainty, the very first Russian fortress constructed in Bashkiria was Birsk, not Ufa. See, V. N. Tatishchev, Leksikon Rossiiskoi Istoricheskoi Geograficheskoi, Politicheskoi i Grazhdanskoi. (Leningrad: 1977), 153.
} 
as diplomatic center through which Russian authorities conducted diplomatic relations with Kazakhs and Central Asians as well. ${ }^{56}$ The chief administrator, the voevoda or military governor, resided in Ufa, conducting governmental duties relating to the region. These military governors were the chief instruments of the central government and their primary duty was to ensure the steady flow of Iasak payments and to monitor Bashkirs and other peoples. They were unable to back Bashkirs against the attacks of other people, i.e. Kazakhs, who lived beyond Russian border. The Russians were supposed to give support to Bashkirs as part of their obligations mentioned in the vassalage documents but the Russian authorities never seriously considered fulfilling this promise. Russians took the vassalage agreement into consideration in a one-sided way: Bashkirs were supposed to protect Russia's southeastern borders not vice versa.

The first people who arrived in Ufa were, quite naturally for a frontier town, officials, Service Tatars, novokreshcheny or New Converts, tolmachy or translators, and the most numerous group, streltsy or musketeers. Ufa began with 150 people whose food was sent from the central provinces, a practice that seemed most impractical considering the distance, lack of roads, climatic conditions and ecology. There was a thin line between civilization (in this case agricultural production) and wilderness. The immediate needs of the garrison of Ufa broke this line and in central Bashkiria agriculture was started by these officials, soldiers and others after the government distributed to them seeds of rye, oat and barley. ${ }^{57}$ At the beginning the land seizures by the Russians took place in the vicinities of the town but with the arrival of new settlers at the beginning of the sixteenth century land seizures increased. Even though those Bashkirs in the western parts of the region were not alien to sedentary life and agriculture, the

\footnotetext{
${ }^{56}$ Zufar Enikeev, Pravovoi Status Bashkortostana v Sostave Rossii; Istoriko-Pravovoe Issledovanie, (Ufa: Gilem, 2002), 58.

57 "Tekst "Otvodnoi Knigi po Ufe" (1591/92-1629 gg.)" in Iz Istorii Feodalizma i Kapitalizma v Bashkirii - Stati ed. S. M. Vasil'eva, (Ufa: 1971), 261-267.
} 
ones who lived in central, eastern and southern parts were more nomadic than sedentary. Under Russian direction agricultural life was about to begin in those areas. So storm clouds were slowly appearing on the horizon.

In the 1500 s, considering the fragility of their situation in the region, the Russian attitude was based on gaining the acquiescence of the Bashkir groups by keeping a low profile. Although the construction of Ufa was undertaken only after the consent of the indigenous people which proved to be a very remarkable event, it quickly became an inseparable part of Russia. Its location gave a strategic advantage to the Russians since it was founded right in the middle of the region at the confluence of the Belaia and Ufa Rivers.

The Russian government needed this town for a number of reasons. First of all it would enable Russians to improve their lot in a region where tribal aristocratic system of Bashkirs were highly volatile and Russians felt compelled to make a strong showing to guarantee regular flow of Iasak payments to the central treasure. Russians soon after the incorporation realized that only those Bashkirs who lived around towns, Ufa and Birsk ${ }^{58}$, both founded in 1574, Osa, founded in 1591, and called Novo-Nikolskaya Sloboda, at the time paid Iasak on a regular bases, so the taxation of all Bashkirs was a primary requirement. ${ }^{59}$ These were followed by Menzelinsk in 1645 and as part of Trans-Kama line strongholds, Belyi Iar, Eryklinsk, Tiinsk, Biliarsk, Novosheshminsk, Kichuevsk and Zainsk, were founded. ${ }^{60}$ When Russians felt themselves threatened by the Kalmyks they had hastily erected a number of fortresses and combined them in

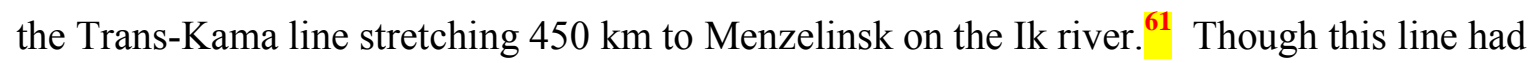

\footnotetext{
${ }_{58}^{58}$ Birsk was officially a village until 1663 .

${ }^{59}$ N. A. Popov, V. N. Tatishchev i Ego Vremia (Moskva:1861), 161-162 Popov gives different dates for the construction of those towns/settlements. He claims that Birsk was founded in 1554. Osa in 1557, Ufa in 1586. ${ }^{60}$ I. G. Akmanov, Bashkiriia v Sostave Rossiiskogo Gosudarstva 17-Pervoi Polovine 18 Veka (Sverdlovsk: Izdatel'stvo Ural'skogo Universiteta, 1991), 48.

${ }^{61}$ Brian L. Davies, Warfare, State and Society on the Black Sea Steppe, 1500-1700 (London and New York: Routledge, 2007), 92.
} 
been erected against Kalmyks it could quite adequately be used against Bashkir autonomy to strengthen Russian presence in the region. Russian authorities could argue that this line was specifically built for the security of Bashkirs against Kalmyk onslaught.

Russians' construction of these fortress towns along Trans-Kama defensive line increasingly alienated Bashkirs but it was inconceivable for a power as centralized as Russia not to establish strongholds in its own territory to ensure the payment of Iasak, which was a considerable amount. Russian authorities did not tolerate the loss of these payments because the military expenses especially during the second half of the seventeenth century accumulated at an enormous pace. How this goal could be achieved without antagonizing Bashkirs remained enigmatic for the Russians until the mid-1700s. Still, Russian authorities delayed the colonization of those lands where Bashkirs paid their taxes in order not to interrupt Iasak payments.

The Siberian Khanate's leader Kuchum Khan's energetic policies to the east of Russia's newly added territories also perturbed Russian authorities. It was clear that without destroying the Siberian Khanate Russian security in the region would never be fully achieved. In this context Ufa, not far away from Siberian Khanate, would be a strong point for the Russian designs and future conquest of Siberian khanate. As a newly rising colonial power, Russia had every reason to fear a coalition of nomads. The incentive to go east could be explained not solely for Russian hunger for furs but also for security.

Russian security concerns increased with the influx of disgruntled, anti-Russian groups into the region including Tatars, Maris, Chuvash, and Cheremis. These groups initially strengthened the anti-Russian potential among Bashkirs but in the long run they played a prominent role in the transformation of Bashkir society into a more sedentary and more Islamic 
one. Though at the time Russian authorities were solely interested in their rebellious potential they were not aware of their positive contributions to the economy of the region by opening more and more lands to agriculture and bringing Bashkirs to a more reasonable level of sedentary culture. The strategic importance of these people together with the Russian population was visible in their agricultural activities and production of food that supported the town population and garrisons in the distant areas.

\section{Conclusion}

The Russian advance into the Bashkir lands created radical changes both for Bashkirs and the Russians. Russians encountered a fully nomadic culture and during the initial periods of its rule in the region they had neither the desire nor the power to alter the basic ways of life in Bashkiria. Yet quite naturally their economic and military power made them a strong party in the steppe politics and Bashkirs most of the time during this period sought Russian intervention to solve their problems with the other Bashkirs and non-Bashkir groups. Partly because of these factors trade and exchanges with the sedentary societies were vital for the smooth functioning for the nomadic societies and the Russians' leverage increased significantly among the Bashkirs. ${ }^{62}$ So without any premeditated state policy Russian influence extended deep into the nomadic life and affected seriously the traditional form of life. In this context it can be argued that even if a colonial state did not wish to transform the indigenous populations their influence and might had transforming effects for the natives.

On the other hand the Russians' goals in the region, like security or orderly flow of Iasak payments, conflicted the requirements of nomadism. The cultural gap also added fuel to this

\footnotetext{
${ }^{62}$ Anatoly Khazanov has argued that nomadic societies were dependent on the sedentary economies for the goods which they were unable to produce. Anatoly Khazanov, Nomads and the Outside World, 2nd ed., trans Julia Crookendon (Madison: University of Wisconsin Press, 1994)
} 
conflict and by the end of the first period in the Russo-Bashkir relations the clouds of clashes appeared in the horizon. 


\section{Chapter 2 \\ Bashkirs and Russian wars of the Seventeenth and Early Eighteenth Century}

This chapter discusses the formative period of the Russian empire and its policies in Bashkiria that led to a number of violent armed clashes between the intruder and the natives. The Russian state's policy during this period was largely confined to the security of the region and the orderly collection of Iasak. The security of the region required the construction of a number of fortifications which hampered the traditional Bashkir nomadic economy. These fortifications also led to the migrations from the middle Volga region and the European parts of Russia which further aggravated the local economic conditions. The land seizures during this period appeared the single most important reason for the outbreak of Bashkir rebellions against Muscovite Russia.

By nature the empires are more flexible and they provide greater opportunities for the ruling and the ruled than the more rigid nation states. The flexibility of empires enables them to maneuver without much restraint. Though an unequal relationship exists between the imperial center and the peripheral communities, it is undeniable that for the most part it is a win-win relationship since imperial administrative structure can provide bases for indirect rule and the periphery takes the advantage of a mighty patron. ${ }^{1}$

Initially Bashkir groups that recognized Russian suzerainty benefited from this relationship by obtaining at least formal protection and strengthening their position against the rival nomadic groups like Kazakhs who from time to time raided Bashkir territory. One of the Kazakh raids in 1573 penetrated Bashkir territory as deep as the Chusovoi River, modern day Yekaterinburg, 228 miles northeast of Ufa. Russian construction of fortifications started in

${ }^{1}$ Alexei Miller \& Alfred J. Rieber, ed., Imperial Rule, (Budapest \& New York: CEU Press, 2004), 1-2 
earnest in southern Siberia. These fortifications also benefitted the Bashkirs by protecting their herds and pasturelands. ${ }^{2}$ Ironically, this increasing security of the region led to the deterioration of the pastoral economy and Bashkir nomads found no alternative but to resist further encroachments of the imperial authority in their native lands.

\section{Russo-Bashkir Relations in the Period of Early Russian Modernization, $17^{\text {th }}-$ Early $18^{\text {th }}$ Centuries}

By and large historians from Russian and Bashkir backgrounds agree on the view that Russian policy in the Bashkir region by the beginning of the modernization of Russia under the heavy thumb of Peter the Great was based on the policy of non-interference. This view was also shared by French historian Roger Portal who stated that Russian policy towards Bashkiria was very cautious. Otherwise, he argued, Bashkirs could have migrated to the southern steppes and recognized the suzerainty of the Kazakh khans, and the Russian treasury would have lost a pool of tax payers who provided much coveted furs to the Russian treasury. ${ }^{3}$ Portal fails to grasp the realities of the steppe politics in the late 1500s. For one thing, the Kazakh Khan's incursions into the Jungar territory and plunder of Jungar property skyrocketed hostilities between Kazakhs and Jungars and resulted in Kazakhs' search for relief from Moscow. They sent an embassy in 1594 to Moscow and requested Russian patronage against Jungars. ${ }^{4}$ For the other, Bashkirs and Kazakhs, ethnic, linguistic, religious affinities notwithstanding, were rivals over grazing lands. Bashkirs, in contrast to Portal's view, sought protection against Kazakhs.

\footnotetext{
2. A. Kuzembaiyly \& E. Abilev, Istoriia Kazakhstana s Drevneishikh Vremen do 20-kh Godov 20 v. (Almaty: Sanat, 1996), 158

${ }^{3}$ Roger Portal, Rossia i Bashkiry; Istoriia Vzaimootnosheniia 1662-1798, 11; available at http://kraeved.opck.org/biblioteka/bashkortostan/rossia_i_bashkiri/rossia_i_ bashkiri.pdf accessed on 7 April 2008

${ }^{4}$ Fred W. Bergholz, The Partition of the Steppe: The Struggle of the Russians, Manchus, and the Zunghar Mongols for Empire in Central Asia, 1619-1758, A Study in Power Politics (New York: Peter Lang Publishing, 1993), 354.
} 
The arguments about the policy of non-interference contrast with some of the historical facts. The Russian historian D. A. Safonov minimizes the size of the Russian population and their settlements in the region. He argues that Russian presence in Bashkortostan for a sufficiently long period, embodied in the establishment of several settlements, including Ufa and a small number of fortresses and a number of unauthorized immigrants, did not violate the traditional lifestyle of local people. So, in his mind, Moscow almost never interfered in the internal affairs of the Bashkirs. ${ }^{5}$ It could also be asked whether Russians did not or could not interfere in Bashkir relations vigorously because of the many years of crisis which lasted nearly from the death of Ivan the Terrible in 1584 to the end of the Time of Troubles in 1613, and even after than that when Russians needed a period of recuperation from their former crises.

On the other hand, Safonov's underestimation can easily be challenged by examining the data on Russian land acquisition and considering the rise of rebellious tendencies among the Bashkir population as of the 1640s. The land distribution among Russian officials serving in the region had started seriously by the 1590 s. The landlords and streltsy were distributed generous amounts of land in the area surrounding Ufa. ${ }^{6}$ In fact the foundation of the town began Russian colonization in the region. ${ }^{7}$ As each new fort was established again the officials serving in these forts were given new lands and this accumulated in enormous amounts at the cost of Bashkir pasturelands. By the year 1700, in Bashkiria there were about 162 dvoriane, of whom 79 owned

\footnotetext{
${ }^{5}$ D. A. Safonov, Nachalo Orenburgskoi Istorii (Sozdanie Orenburgskoi Gubernii v Seredine 18 v.) (Orenburg, 2003), 11; available at http://kraeved.opck.org/biblioteka/kraevedenie/nachalo_orenburgskoi_istorii /nachalo_orenburgskoi_istorii.exe accessed on 14 May 2008.

${ }^{6}$ A. I. Akmanov, Zemelnaia Politika Tsarskogo Pravitelstva v Bashkirii Vtoraia Polovina 16-Nachalo $20 \mathrm{vv}$. (Ufa: Kitap, 2000), 16.

${ }^{7}$ V. N. Vitevskii, I.I. Nepliuev i Orenburgskii Krai v Prezhnem Ego Sostave do 1758 g.; Istoricheskaia Monografiia. Volume 1 (Kazan:1897), 374.
} 
land amounting from 250 to 480 chetverts and 83 owned from 500 to 1000 chetverts. ${ }^{8}$ These lands distributed among the Russian officials clustered around the towns or fortresses where it was easier to defend them from attacks. ${ }^{9}$

Besides these fortifications, the construction of monasteries in the region was well underway by the end of the same century. The first stone monastery in the region, Smolenskii Bozhei Materi, was constructed in 1579, soon after Ufa was founded in 1574. Additional monasteries including Preobrazhenskii, Spaso-Preobrazhenskii, Bogoroditskii, Uspenskii, Khristorozhdestvenskii, Voznesenskii, and Dolmatovskii had already been erected in the region by the beginning of the seventeenth century. All these monasteries had the right to the land and the Imperial government granted them Bashkirs' votchina lands. ${ }^{10}$ They carved out lands for their livelihood that became the targets of Bashkir hostility, and many of them were destroyed by Bashkirs during the rebellions of the same century.

In fact Bashkir attacks on these units were frequent even when there was not a Bashkir rebellion. For example, the monks of the Voznesensk monastery were supposed to produce salt from a nearby river but they never managed to perform this task because of Bashkir raids. ${ }^{11}$ Some authors argued that these monasteries were founded by the Russian government because there were sufficient numbers of Orthodox believers in the region by the 1570 s who needed church services. ${ }^{12}$ Earlier construction of monasteries after the conquest of Kazan and Astrakhan in the 1500s suggests, however, that the interests of the government and the Orthodox

\footnotetext{
${ }^{8}$ A. I. Akmanov, Zemelnye Otnosheniia v Bashkortostane i Bashkirskoe Zemlevladenie vo Vtoroi Polovine 16Nachale 20 v. (Ufa: Kitap, 2007), 77; "Tekst "Otvodnoi Knigi po Ufe" (1591/92-1629 gg.)" in Iz Istorii Feodalizma i Kapitalizma v Bashkirii - Stati ed. S. M. Vasil'eva, (Ufa: 1971), 261-267.

${ }^{9}$ A chetvert is half of desiatin and a desiatin is 1.09 Hectare.

${ }^{10}$ I. G. Akmanov, Bashkirskie Vosstania (Ufa: Kitap, 1993), 58.

${ }^{11}$ Iu. N. Sergeev, "Tserkovno-Monastyrskoe Zemlevladenie v Bashkirii Konets 16-Seredina 18 v." In Sotsial'noEkonomicheskoe i Politicheskoe Razvitie Bashkirii v Kontse 16-Nachale 20 vv. ed., I. M. Gvozdikova, Kh. F. Usmanov and M. I. Rodnov, (Ufa, 1992), 12.

${ }^{12}$ Istoriia Ufy: Kratkii Ocherk, (Ufa: Bashkirskoe Knizhnoe Izdatel'stvo, 1981), 23.
} 
Church were intertwined in managing the peripheral regions and that a large Christian population was not necessary to justify the establishment of a monastery in the frontier. So the Orthodox Church became a key player in the colonial politics of the Muscovite Russia and the foundation of Smolenskii Bozhei Materi around Ufa was not coincidental. It was hoped that it would supply much needed goods to the urban center. ${ }^{13}$

Bashkirs repeatedly sent petitions to Moscow to complain about the burdensome taxes and the corruption of Russian officials in the region. In particular, the corruption of tax collectors reached such a level of apogee that in many of their petitions Bashkirs demanded their removal or replacement with more honest ones. The legendary corruption of Russian officials was based on fact. Generally only the worst and most rapacious ones accepted such a distasteful job as tax collector in the remote and backward regions. They had every opportunity to enrich themselves by exploiting the local population since they knew that their excesses would go unheeded because the tsarist central government lacked competent personnel and was in no position to find alternative officials. On the other hand the coffers of Muscovite treasury had never been rich enough to pay its officials a regular salary, lack of which in turn gave them no alternative but to rely on the money extracted from the local population. A tax collector used to receive his pay from surpluses collected above the amount due for taxes which took the form of veiled robbery in the name of government and did everything possible to squeeze Bashkir iasak payers. This near robbery by Russian officials was not without good reason because at that time

\footnotetext{
${ }^{13}$ For greater detail about the role of the monasteries in Russia's frontiers see Matthew Paul Romaniello, "Controlling the Frontier: Monasteries and Infrastructure in the Volga Region, 1552-1682" Central Asian Survey 19 (2000), 429-443.; Matthew Paul Romaniello, “Absolutism and Empire: Governance On Russia's Early-Modern Frontier" (PhD diss., Ohio State University, 2003), 169-173.
} 
an average family of four in European Russia who tilled 40 acres of land earned only a ruble a year, while the price of a sable pelt was several rubles. ${ }^{14}$

Aside from Iasak, Bashkirs were also made to pay customs dues and taxes on horses, tobacco, and other items. Customs were collected not only from goods actually sold, but from any cattle and other things which Bashkirs gave to each other, like gifts in the form of bride money and dowry. Where there were no customs centers, the equestrian tax officials visited volosts and auls (small Bashkir or Tatar settlements) and collected taxes without controls or regulations, causing serious abuses. ${ }^{15}$

The arguments about Russian non-interference in Bashkiria considering these sources are accordingly unjustified. Bashkirs constantly felt betrayed by the Russian tsars' so-called grant of "Bashkir autonomy" since Russians already violated the most basic terms of their charter about Bashkirs' rights to the land. As a result of these land claims by agriculturalists, Bashkir mobility was seriously restricted, which unavoidably created hostilities. The discontents over land and taxes grew over the seventeenth century and ultimately culminated in a number of rebellions in the 1660 s and 1680 s.

\section{Russian Administration of the Bashkirs in the $17^{\text {th }}$ Century}

The Russian conquest of the Kazan, Astrakhan, Nogai, and Sibir khanates brought Bashkirs under a single government, so this Russian takeover of these regions also meant unification of Bashkir lands. Yet not all Bashkirs were treated equally under Russians. Those groups who lived under the Siberian khanate offered some resistance to Russian eastward

\footnotetext{
${ }^{14}$ W. Bruce Lincoln, The Conquest of a Continent: Siberia and the Russians, (New York: Random House, 1994), 82.

${ }^{15}$ I. G. Akmanov, "O Nalogakh i Povinnostiakh Bashkir v 17-Nachale 18 vv." In Voprosy Agrarno Istorii Urala $i$ Zapadnoi Sibiri, ed., F. S. Govoroi, (Sverdlovsk: UGU, 1966), 104.
} 
movement so they were not given vassalage status and their taxes were heavier. The Russian military and administrative presence in the Osinskoi uezd was much stronger than in the southern Urals even though the latter was closer to Moscow and was just a step away from the Middle Volga region where there was a considerable Russian military presence and peasant colonization. The next step for Russian colonization was seemingly western and southern Bashkiria. ${ }^{16}$ Russia’s Siberian administration, unlike the Ufa administration, did not consider any difference between Bashkirs of the region and the other natives.

How can we explain this contradictory treatment of different Bashkir groups? The Russian government sensed that trans-Ural Bashkirs would pose less of a problem than the Bashkirs of former Kazan and Nogai dorogas on demographic grounds. The population of Bashkirs in the Ufimskii Uezd at the end of the seventeenth century was around $100,000^{17}$ while around the same time the Bashkir population of Tiumenskii uezd in western Bashkiria was considerably smaller. ${ }^{18}$ Still, the eastern Bashkirs considered it a right to have vassalage as long as their western brethren enjoyed such privileges.

The Russian government during the second half of the seventeenth century granted these same rights to them as well. This was a harbinger of the future Russian efforts to integrate Bashkirs to the Russian imperial system due to the fact that the Russian imperial system desired to create a system of uniformity for the same ethnic groups within the Russian empire to

\footnotetext{
${ }^{16}$ A. I. Dimitriev, "K Istorii Zaural'skoi Torgovli. Bashkiriia pri Nachale Russkoi Kolonizatsii” Permskaia Starina (Perm: 1890), 76.

${ }^{17}$ R. G. Kuzeev, Istoricheskaia Etnografiia Bashkirskogo Naroda (Ufa: Bashkirskoe Knizhnoe Izdatel'stvo, 1978), 45.

${ }^{18}$ I do not have any reliable data about the Bashkir population in the Trans-Ural Bashkiria. I just made an approximation depending upon the number of Iasak payers during the first half of the seventeenth century whose number was around 300 while the in Ufa district in 1639 there were 6188 Iasak payers. For greater detail see B. O. Dolgikh, Rodovoi i Plemennoi Sostav Narodov Sibiri v 17 Veke (Moskva: Izdatel'stvo Akademii Nauk SSSR, 1960), 54; N. I. Nikitin, Sluzhilye Liudi v Zapadnoi Sibiri 17 Veka (Novosibirsk: Nauka, 1988), 82; B. A. Aznabaev, Integratsiia Bashkirii v Administrativnuiu Strukturu Rossiiskogo Gosudarstva (Vtoraia Polovina 16-Pervaia Treti 18 vv.) (Ufa: RIO BashGU, 2005), 77-78.
} 
facilitate their firm integration into the system. To deprive some groups within the same ethnic communities could lead to jealousy and accordingly intergroup fighting and fighting against the central authority.

The most direct example of Russian authority in Bashkiria was the collection of tribute, either in kind or in cash. The amount of tribute has been a matter of vivid debate among the imperial Russian and Soviet historians. For example, Bashkir historian I. G. Akmanov argued that the major reason for the rebellions of Bashkirs was the exorbitantly high Iasak payments which drove Bashkirs to helplessness. On the other hand, the eighteenth century Russian historian, P. I. Rychkov, a native of Orenburg, argued that Bashkirs paid considerably less to their Russian overlords than to their former masters, Nogais. ${ }^{19}$ A great many of the regional historians claim that the Iasak collection was irregular, not collected in a timely manner and its amount was negligible. ${ }^{20}$ B. A. Kulbakhtin argues that Iasak collection in Bashkiria lacked regularity and uniformity to the extent that between 1600 and 1740 for various reasons Iasak was not collected from Bashkirs of Ufa uezd for some fifty years. Other than that, Iasak demands from Bashkirs were very light and the amount remained same between 1631 and $1702 .^{21}$ The amount of the tribute paid by Bashkir nomads is not always possible to determine with precision, because most inventories about the Iasak payments have been lost. In addition, most of the nomadic Bashkirs deliberately escaped Iasak payment which prevented the Muscovite

\footnotetext{
${ }^{19}$ P. I. Rychkov, Topografiia Orenburgskoi Gubernii (Ufa: Kitap, 1999), 51.

${ }^{20}$ For some of those historians who maintain that Iasak was negligible see; B. A. Aznabaev, Integratsiia Bashkirii v Administrativnuiu Strukturu Rossiiskogo Gosudarstva (Vtoraia Polovina 16-Pervaia Treti 18 vv.) (Ufa: RIO BashGU, 2005), 80-81; N. V. Ustiugov, "O Kharaktere Bashkirskikh Vostanii 17-Pervoi Poloviny 18 vv." in Materialy Nauchnoi Sessii posviashchennoi 400-letiiu prisoedineniia Bashkirii k Russkomu Gosudarstvu, ed. N. V. Ustiugov and R. G. Kuzeev, (Ufa: 1958), 86-100: A. N. Usmanov, Prisoedinenie Bashkiriia k Russkomu Gosudarstvu (Ufa: 1960), 145: N. F. Demidova, "Upravlenie Bashkiriei v Pervoi Treti 18 v." Istoricheskie Zapiski, 68 (1961), 214-221.

${ }^{21}$ B. A. Aznabaev, Integratsiia Bashkirii v Administrativnuiu Strukturu Rossiiskogo Gosudarstva (Vtoraia Polovina 16-Pervaia Treti 18 vv.) (Ufa: RIO BashGU, 2005), 80-81.
} 
government throughout the seventeenth century from forming lists that revealed the names of Iasak-payers. $^{22}$

There are reasons for this governmental leniency. The preeminent goal of the government in the region was the security of the southeastern frontier for which Bashkirs could be the best Russian agents. They served this goal primarily because Bashkirs were more hostile to the Nogais as their age old rivals for pasturelands than to the Russians, a new-coming group whose real intentions Bashkirs did not know yet. There was also a practical side of the issue in collecting Iasak. According to Ustiugov the amount of Iasak paid by Bashkirs from the 1630s to the 1730 s was around 25 kopecks per household annually. This amount was much less than what was paid by Russian peasants in the neighboring uezds. However Bashkirs were also expected to join Russian military campaigns on their own account without getting any compensation from the government. Considering the weakness of productive forces in Bashkiria and military service this amount of tax could be onerous. ${ }^{23}$

The Soviet and post-Soviet historians maintain this view while national historians like Vakhit Imamov, a Tatar nationalist and anti-Russian writer who tends to view Bashkirs as part of a greater Tatar nation, argues that Russian Iasak collection was robbery based on the whims and ambitions of the tax collectors. ${ }^{24}$ But from the few archival sources available it seems that Iasak collection was irregular with no fixed rate, completely dependent on the necessities of the Russian central government and the rapaciousness of the local administrators. Iasak payment was a logical result of Bashkirs' recognition of the Russian tsar as the ultimate protector of

\footnotetext{
${ }^{22}$ N. V. Ustiugov, “Bashkirskoe Vosstanie 1662-1664 gg.” Istoricheskie Zapiski, 24 (1947), 30.

${ }^{23}$ N. V. Ustiugov, "O Kharaktere Bashkirskikh Vostanii 17-Pervoi Poloviny 18 vv." in Materialy Nauchnoi Sessii posviashchennoi 400-letiiu prisoedineniia Bashkirii k Russkomu Gosudarstvu, ed. N. V. Ustiugov and R. G. Kuzeev, (Ufa: 1958), 107

${ }^{24}$ Vakhit Imamov, Zapriatannaia Istoriia Tatar; Natsional'no-Osvoboditel'naia Bor'ba Tatarskogo Naroda v 16-18 Vekakh za Sozdanie Nezavisimogo Gosudarstvo (Naberezhnye Chelny: Gazetno-knizhnoe izd-vo, 1994), 16.
} 
Bashkirs against other nomadic groups. Even though the local Russian authorities were quite exorbitant in their demands, the central government followed a policy of tolerance towards the natives since they needed Bashkirs as patrols along Russia's southeastern borders.

The long run result of this reliance on Bashkirs as the main military agents of the government in the southeastern frontier was that Russian military presence was weak for nearly a century after the incorporation of the region into the Russian empire in the 1550 s. The size of the major fortress in Bashkiria is revealing in this respect. Ufa was the smallest of all Russian frontier towns with the length of its walls around 440 meters. $^{25}$

Yet the Russians were inconsistent in their rule over the Bashkirs. Definitely there are cases that indicated that Russians saw themselves as the masters of Bashkir lands. On the other hand the government officials at certain stages during the seventeenth century asked for the opinion of Bashkirs about some issues. In one case, a certain Nogai mirza Saltan in 1643 requested from the Ufa administration to receive Russian clientage and pasturelands for his ulus (in total 1300 people) in Ufa uezd. The reply reached him only after Voevoda of Ufa informed Bashkirs and asked their opinion about the issue. When the Bashkir response turned out to be negative, the request of Nogai mirza was declined. ${ }^{26}$ This apparent Russian cooperation with the Bashkirs and their respect of the Bashkir votchina rights changed character with the arrival of a significant force of Kalmyks in the region. Russians started favoring Kalmyks to the detriment of Bashkir interest in the region and they granted chunks of Bashkir lands to Kalmyks which was one cause of the first genuine Bashkir rebellion in 1645 against these Russian arrangements. The Bashkir rebellion was led mainly by trans-Zama Bashkirs in direct reaction to the construction of

\footnotetext{
${ }^{25}$ Kulbakhtin uses Bukanova's work Goroda Kreposti (see fn. 46) as his source about the length of the walls of Ufa but Bukanova's book has no such information.

${ }^{26}$ B. A. Aznabaev, Integratsiia Bashkirii v Administrativnuiu Strukturu Rossiiskogo Gosudarstva (Vtoraia Polovina 16-Pervaia Treti 18 vv.) (Ufa: RIO BashGU, 2005), 82.
} 
Menzelinsk fortress by the government without the consent of the Bashkirs living in the area. Accordingly, it had a local character and failed in its objectives. ${ }^{27}$

\section{Bashkir Rebellions of the Mid-16 ${ }^{\text {th }}$ - Early $17^{\text {th }}$ centuries}

The Bashkirs' rebellions against Russian policies in the region started soon after they felt upset about the Russians' volatility and evident corruption. The first violent clash broke out as early as 1572 . It was followed by others in $1583,1587,1603,1608$ and $1616 .^{28}$ These were not full-scale uprisings but extremely localized incidents and did not cause any radical shift in the Russians' posture in the region. On the other hand, in these incidents Bashkirs were not the driving force but were just one of many participants. All non-Russian nationalities of Bashkiria actively resisted Russians. Although they were, unlike Bashkirs, not nomads, they had their own reasons to resist Russian policies in the region. The most immediate reason for their rebelliousness was their expulsion from the Middle Volga region and proselytizing attempts of the Russian missionaries.

Still the Bashkir attack against the newly founded Menzelinsk fortress in 1645 was the harbinger of future and more massive Bashkir resistance. For one thing, it was much more brutal than earlier incidents. Russians had to mobilize their forces in the region to quell this rebellion. Bashkirs also for the first time dared to attack a major Russian fortress which was a symbol of Russian authority in Bashkiria. The reason for the outbreak of the rebellion was the construction of the fortress of Menzele against the objections of the Bashkirs. This was in fact a major violation of Bashkirs' votchina rights and the rebels' goal was to get rid of the Russians from the

\footnotetext{
${ }^{27}$ R. G. Bukanova, Goroda-Kreposti Iugo-Vostoka Rossii v 18 Veke Istoriia Stonovleniia Gorodov na Territorii Bashkirii (Ufa: Kitap, 1997), 62.

${ }^{28}$ Permskaia Letopis, Pervyi Periods 12631613 gg., (Perm:1881), 98; Permskaia Letopis, Vtoroi Period, s 1613 1645 gg. (Perm: 1881), 68; R. N. Zinurov, Bashkirskie Vosstaniia i Indeiskie Voiny: Fenomen v Mirovoi Istorii (Ufa: Gilem, 2001), 96.
} 
region. $^{29}$ This rebellion was initiated by Bashkirs but it remained a highly localized one, aimed specifically against the Menzelinsk fortress and easily crushed by Russians. Russian's vulnerable position in the region had made them side with the stronger nomadic group, the Kalmyks, at the cost of compromising their promises to Bashkirs who were supposedly under Russian protection, according to the terms of the famous charter of Ivan the Terrible.

By 1660 Bashkirs had long-standing grievances that would recur later: the seizure of Bashkir lands for the construction of fortresses by the Russian government and / or their distribution to the Russian nobles; and the completion of the Trans-Kama defensive line by the mid-1650s that threatened traditional forms of Bashkir life by restricting their free movement within Bashkiria. Russia's increasing imperial claims in the west, the Polish war of 1654-1667, and Russia's clashes with Sweden over Livonia caused a remarkable rise in the taxes. To escape these increased tax demands, many Bashkirs fled to nearby nomadic groups beyond Russian control or to distant areas within the Russian empire where governmental control was considerably weaker. In 1660, the Russian envoy to the Kalmyks, Ivan Savvich Gorokhov, met with 30 Bashkir families in the Kalmyk camp. When he questioned their reason for residing among Kalmyks, they responded that they were from Ufa and overburdened by the taxes imposed by the Russian voevoda (military governor) of Ufa. ${ }^{30}$ So the tyranny and the inflated demands of the central government was another factor for the rise of hostilities.

One last reason for the rise of tensions between the Russians and the Bashkirs was that the Russians provided protection to Kalmyks in the 1650s. The Kalmyks were a nomadic people of Mongol stock, and were traditional enemies of the Bashkirs, who clashed with them over pasture lands in southern and southwestern Bashkiria. Russians' favorable treatment of Kalmyks

\footnotetext{
${ }^{29}$ M. K. Liubavskii, Obzor Istorii Russkoi Kolonizatsii s Drevneishikh Vremen i do 20 Veka (Moskva: Izdatel'stvo Moskovskogo Universiteta, 1996), 494.

${ }^{30}$ N. V. Ustiugov, “Bashkirskoe Vosstanie 1662-1664 gg.” Istoricheskie Zapiski, 24 (1947), 36.
} 
to the disadvantage of Bashkirs, by authorizing the transfer of some Bashkir lands to the Kalmyks' usage, even if only on paper, antagonized Bashkirs. This Russian grant of Bashkir lands to Kalmyks was evidence that Russians saw themselves as the owners of Bashkir lands. ${ }^{31}$

In the meantime it must be noted that Russia's patronage over Kalmyks hints at the volatility of their authority in the region because of the fact that although the government forbade Bashkirs from raiding Kalmyks, this was ineffectual and Kalmyks kept complaining about Bashkir raids. In some cases they refused to join Russia's military expeditions on the grounds that their lands were under Bashkir attack. Russians were in fact in a troubled position. Their intention was not to leave Bashkirs to the mercy of Kalmyks but to exploit Kalmyk belligerence in their Polish wars and to direct Kalmyks' cavalry regiments against Crimea, an ally of the Poles at the time. ${ }^{32}$

To gain Kalmyk loyalty, Russian officials spent efforts to pacify the Bashkirs, who were raiding Kalmyks. As one Russian envoy to the Kalmyk camp stated, upon the request by the Kalmyk Taishi, a certain Russian official named Somov was sent to Ufa with the instructions to search among Bashkirs for Kalmyk goods and return them to the Kalmyks. The worst Bashkir thieves were put to death, and the others were fined. This caused a reaction among Bashkirs, and at least two dozen Bashkirs left Bashkiria to join very surprisingly the band of one of the sons of Kalmyk Taishi ${ }^{33}$, a move that utterly frustrated Russian authorities. They immediately dispatched their envoys to search the case and the reasons for the Kalmyk hospitality to these Bashkir raiders of Kalmyk property.

\footnotetext{
${ }^{31}$ I. G. Akmanov, ed., Istoriia Bashkortostana s Drevneishikh Vremen do Nashikh Dnei v Dvukh Tomakh v. 1, (Ufa: Kitap, 2007), 144-145; I. G. Akmanov, Bashkirskie Vosstaniia 17-Pervoi Treti 18 v. (Ufa: Bashkirskie Gosuniversitet, 1978), 28-29.

${ }^{32}$ Charles A. Riess, "The History of the Kalmyk Khanate to 1724" (PhD diss., Indiana University, 1983), 197.

${ }^{33}$ Sergei M. Soloviev, History of Russia Vol. 23: Tsar Alexis, A Reign Ends (Academic International Press, 1998), 94. (Translated by Martha L. Lahana)
} 
The relations on the frontier between Russians and nomads and among nomads themselves were more complicated than they appeared. The loyalties could shift at lightning speed. Russians had troubles adjusting themselves to this volatile nature of steppe diplomacy ${ }^{34}$ and they were at a crossroad to choose the side of Bashkirs against Kalmyks or to buy the services of Kalmyks at the cost of antagonizing Bashkirs. If Bashkirs were to be in a position to serve Russians in their campaigns in the west and south, as a more or less unified group like the Kalmyks with a commonly recognized, even if nominally, Bashkir leader, then the clashes between Kalmyks and Bashkirs would have to be resolved in favor of the latter. Given the circumstances, authorities were compelled to ignore Bashkir interest which irked Bashkirs deeply and led to their rebellion. The causes were clear. Bashkirs felt betrayed because they had been favored by Russians until 1661 against Kalmyks and upon Russian orders, Bashkirs were deprived of a source of revenue which they achieved through their raids of the Kalmyk camps. ${ }^{35}$ As Russians felt themselves strong enough they increasingly violated the terms of the Land Charter they had granted to Bashkirs at the local level, though the central government vainly prohibited the sale, requisition, long-term lease or seizure of Bashkir lands in a number of laws. The most famous law was the Code of 1649 according to which the sale and the lease of the Bashkir lands were strongly prohibited and the violators were threatened with severe punishments. ${ }^{36}$ The terms of the Code of 1649 regarding Bashkirs were later confirmed in a number of decrees in 1664, 1694 and in $1734 .^{37}$ The Soviet and post-Soviet Bashkir historians claim that the government wished to continue the policy of preservation of lands in Bashkir

\footnotetext{
${ }^{34}$ Michael Khodarkovsky explains the volatile nature of steppe diplomacy at length. See Michael Khodarkovsky, Russia's Steppe Frontier: The Making of a Colonial Empire 1500-1800 (Bloomington \& Indianpolis: Indiana University Press, 2002), 39-45.

${ }^{35}$ N. V. Ustiugov, “Bashkirskoe Vosstanie 1662-1664 gg.” Istoricheskie Zapiski, 24 (1947), 56.

${ }^{36}$ M. N. Tikhomirov \& P. P. Epifanov, Sobornoe Ulozhenie 1649 g. (Moskva:Izdatel'stvo Moskovskogo Universitetat, 1961), 187-188.

${ }^{37}$ A. Zaripova, "O Votchinnom Prave Bashkir na Zemliu” Vatandash, (Mart, 2007).
} 
hands as a reflection of the Russian government's benevolence. ${ }^{38}$ This approach, however, is quite problematic. As was discussed earlier, the Russians were the complete masters of Bashkir territory because they claimed for themselves the right to prohibit the sale of Bashkir lands to newcomers to Bashkiria as if they were the owners of Bashkir lands.

The Russian attitude towards the Bashkir lands was on the one hand possessive but on the other unpredictable. It was not clear in the Russian mind which parts of the Bashkir lands would be confiscated and how long and under what conditions, and this unpredictability of the next Russian move caused confusion and frustration among the Bashkirs. If the government was the owner of the Bashkir lands, why had the Tsar granted Bashkirs votchina rights, and time and again confirmed Bashkirs' votchina status as conditions necessitated? If Bashkir rights to the land had been guaranteed by the Tsar, then how could land seizures be explained? The Russian authorities were quite reluctant to discuss the future status of Bashkir lands with the Bashkirs. In fact, the Russian policy in the region was not predetermined but shaped by the developing events in the surrounding areas and this unpredictability of the authorities made Bashkirs seriously worry about their future under the Russians.

It seems that from the very beginning the Russian authorities had no respect for Bashkir autonomy, and practically they had the right to do so because they had no Bashkir counterpart in the form of a universally recognized Bashkir khan who could represent his own people. ${ }^{39} \mathrm{~A} . \mathrm{Z}$. Asfandiiarov maintains that during the first hundred years of Russian suzerainty in Bashkiria, they almost never interfered in the internal affairs of Bashkirs and Bashkirs never sought another overlord. There were only minimal changes like introducing another doroga, Osinskii, at the

\footnotetext{
${ }^{38}$ A. I. Akmanov, Zemel'nye Otnosheniia v Bashkortostane i Bashkirskoe Zemlevladenie vo Vtoroi Polovine 16Nachale 20 v. (Ufa: Kitap, 2007), 81.

${ }^{39}$ The Russian policy of decreeing Bashkir land rights and following contradictory policies may seem inconsistent. But the easiest way of soothing Bashkir rebelliousness was to issue decrees guaranteeing Votchina rights. Instead of fighting, many Bashkirs were too ready to give credit to these Russian promises.
} 
turn of the century. This author, however, overlooks the controversial construction of Menzelinsk fortress at the heart of the Bashkir lands against the will of the Bashkirs that led to a small scale uprising in 1645 . On the other hand Bashkirs also joined other rebellions earlier led by Tatars, and by a number of Finnic groups. A major problem in history writing in Russia is that the historians neglect the small-scale, isolated discontents and present the Russian presence in the region as widely accepted by the indigenous people.

Throughout the history of Bashkir-Russian armed conflicts, one of the major handicaps of the rebellious Bashkirs was that they were always short of time and they had to win, at least initially, some military successes against the Russians to gain the support of the bulk of the Bashkir population. Under the existing circumstances this seemed impossible due to the shortage of military means to defeat a well-organized, well-armed, well-led, well-trained modern army with their primitive nomadic weapons, tactics and logistics. In many instances rebels were caught by surprise and were numerically overwhelmed by the enemy. The existing social structure of the Bashkir society was inadequate to provide a common front against the enemy. The Bashkirs remained too divided in the face of a superior military power. Many of the Bashkirs were too willing to support Russians in the expectations of material gains.

Bashkirs, as it became clear to the Russian authorities in St. Petersburg, were a constant source of distress. The military governor of Kazan, Apraksin, wrote in 1712 that they had almost no troubles with the pagans but the Bashkirs were a constant domestic enemy. They received nothing positive from their actions towards Bashkirs and they were in a state of constant fear of attacks from them. As Soloviev writes; "They had accepted and given shelter to fugitives Russian and of other faiths - refusing to hand them over, notwithstanding repeated demands which they turned down with great insolence; and that they had paid no attention to officials sent 
to them for the purpose of registering and recovering these fugitives, or worse, subjected them to physical abuse and deprived them of their liberty.",40

\section{The Russo-Bashkir Wars in the $17^{\text {th }}$ century and Steppe Politics}

The Bashkir wars against the Russian government began in the 1660s. Although Western scholarship has neglected these events, they were very important because they delayed Russia's southeastern expansion until the early 1800 s, and these wars played an important role in formation of Bashkir politics and society in the long run.

The century of Russo-Bashkir wars lasted until 1775. In Russian historiography these wars are called rebellions (vosstanii), and there is a vast literature about these wars in Imperial, Soviet and post-Soviet history writing. ${ }^{41}$ They have quite legitimate reasons for this approach. First of all the Russian authorities considered themselves the masters of these lands and what they were doing in Bashkiria was the use of their property in ways they saw fit. On the other hand the central government proposed concessions in return for ending rebellion. In the same capacity Russian authorities quite often pardoned rebellious leaders as though they were gracious masters of their subjects. ${ }^{42}$

\footnotetext{
${ }^{40}$ Sergei M. Soloviev, History of Russia: Peter the Great, the Great Reforms Begin. v. 29, (Academic International Press, 1981), 187. (Translated by K. A. Papmehl)

${ }^{41}$ For a limited collection of essays and books; I. G. Akmanov, "Vosstanie 1662-1664 gg.: Pervoe Massovoe Dvizhenie v Bashkirii" in Krest'ianstvo i Krest'ianskoe Dvizhenie v Bashkirii v 17 - Nachale 20 vv. ed., Kh. F. Usmanov, (Ufa: 1981), 45-67; I. G. Akmanov, "Bashkirskoe Vosstanie 1704-1711 gg." in Sbornik Nauchnykh Rabot Aspirantov Istoricheskogo Fakul'teta MGU (1963), 124-153; V. I. Lebedev, "Bashkirskie Vosstanie 1705-1711 gg." Istoricheskie Zapiski, 1, (1937), 81-102; V. D. Puzanov, "Bashkirskie Vosstania 17-18 Vekov v IsetskoPritobolskom Regiona (Iuzhnie Zaurale)" Shadrinskaia Starina, 7, (1999), 133-144; N. V. Ustiugov, "Bashkirskoe Vosstanie 1662-1664 gg.” Istoricheskie Zapiski, 24 (1947), 30-110; Z. I. Siraev, "O Kharaktere Bashkirskikh Vosstanii 17-Pervoi Poloviny 18 vv. (1662-1664 gg.; 1681-1683 gg.; 1704-1711 gg.; 1735-1740 gg.)" in Iz Istorii Bashkirii, Part 2 ed. R. G. Kuzeev, Ufa:1963), 5-23; I. G. Akmanov, Bashkirskie Vosstaniia (Ufa: Kitap, 1993); I. G. Akmanov, Bashkirskie Vosstaniia 17-Pervoi Treti 18 v. (Ufa: 1978); R. N. Zinurov, Bashkirskie Vosstaniia i Indeiskie Voiny: Fenomen v Mirovoi Istorii (Ufa: Gilem, 2001)

${ }^{42}$ In the seventeenth and the eighteenth centuries the Russian central government issued amnesty many times for the rebellious Bashkirs and it even granted them certain privileges, gifts and positions in the administration of the Bashkir society as will be seen in various pages of this essay. For example, Aznagul Uruskalov, one of the leaders of the 1662-64 rebellion was pardoned despite his active role in the rebellion and in the negotiations with the descendants of the Kuchum Khan, the last ruler of the Sibir khanate. See I. G. Akmanov and Aznagul Uruskulov, ed., Bashkirskaia Entsiklopediia, v. 1, (Ufa: Nauchnoe Izdatel'stvo, 2005), 75.
} 
These rebellions generally followed the same pattern and ended in similar ways. Many of the Bashkir leaders renounced their vassalage to the Russian Tsar and sought another patron protector, including their age-old enemies Kalmyks, Kazakhs, descendants of Kuchum Khan in Siberia and even the Crimean Khan at different times and episodes in their wars against Russians. They were caused mainly by the land seizures by the pripushchenniki, new-comers to the region after 1552. Tatars and Finnic groups could be counted within this group as well but the real reaction was directed against the Russian settlers even though their numbers were not as big as Tatars and Finnic groups.

It appears that the reason why Russian settlements were especially attacked is that Russian settlers were identified with the Russian state and abusive Russian officials in the region. Until the reign of Peter the Great, the political leaders in Russia had considered Bashkiria a fur-rich region. During the Muscovite period, fur trade still provided a large share of Russian revenues so there was no urgent need to open the region to extensive agriculture. Russian military might was still not strong enough to impose its will on the highly mobile Bashkirs for which reason Bashkir wars during this period ended in a stalemate. However there were faint signs that growing numbers of Bashkirs were increasingly adopting a sedentary life under the influence of their new neighbors who flocked into the region. Even though there is no reliable data about the intermarriages it can be assumed that Bashkirs and especially Tatar migrants were concluding such marriages. Since these two groups shared the same religion and language, it was not an extraordinary thing to witness such marriages.

Because Bashkirs had ethnic, linguistic, and religious affinities with Tatars and Mishars it was much more difficult to oust these people from Bashkiria from a moral and Islamic point of view. These peoples were also victims of Russian policies in the middle Volga region. On the 
other hand despite Bashkir leadership and initiative in these wars, these formerly Middle Volga residents, especially Tatars and Mansi (Voguls), also supported Bashkir efforts against the Russians.

\section{The Bashkir Rebellion of 1662-1664}

The most immediate reason for the outbreak of rebellion in 1662 appears to have been Russia's siding with Kalmyks to the disadvantage of Bashkirs. This rebellion was not the result of a minor border conflict in fact. The Bashkir lands were part of the greater Russian system and the crisis in the Russian center seriously affected Bashkirs as well. It is clear that despite all counter arguments by Soviet historiography that the Russian influence and presence in the region by the reign of Peter the Great was only minimal, Russians, in fact, were deeply ensconced in Bashkiria and their policies in the center seriously affected the periphery, including Bashkirs.

This rebellion began in 1662 in Ufa uezd and quickly spread to Siberian Bashkiria and the Middle Volga. By the spring of 1663 Bashkirs were attacking defensive positions of the trans-Kama line constructed in the 1650 s by the government against new nomadic threat from Mongolian origin; Kalmyks. This line was also used by the authorities to contain Bashkirs within the Russian empire and to increase governmental control of Bashkir lands. As a result, Bashkirs developed a specific hatred for this line because this line cut across Bashkirs' lands in the 1650s and restricted Bashkir movements in the area. So it appears that this line was in fact designed for this purpose rather than preventing infiltration of Kalmyks into the Russian territory.

Upon hearing the news of a massive rebellion in 1662, the Russian authorities quickly transferred Russian troops from nearby regions and from Moscow to the center of the rebellion. ${ }^{43}$

\footnotetext{
${ }^{43}$ An army was sent from Moscow to quell the rebellion. This is an indicator of the extent of the rebellion. Local Russian garrisons were inadequate to pacify the region. Munir Khadiev, "Istoriia Bashkir" Vatandash, 9, (2007)
} 
What was most alarming to the Russian authorities during this rebellion was that the rebel forces quickly overwhelmed a number of Russian fortified positions and burned some Russian settlements, destroying a number of monasteries. ${ }^{44}$ In the face of the growing threat posed by Bashkir rebels led by some influential Bashkir nobles, including Sary Mergen, Aznagul Uruskulov, Bekzian Toktamyshev, Gaur Akbulatov, Arslanbek Bakkin, ${ }^{45}$ Russian authorities managed to gain the loyalties of the rest of the Bashkir elite. So the organization of the Russian administration was far from being alone in repressing the rebellions. Many of the Bashkir leaders supported the Russian efforts to crush the leaders of the rebellion. In the autumn of 1662 in southeast Bashkiria of Nogai Doroga, some minor Bashkir rebel leaders were captured by loyal Bashkirs and delivered to Volkonski, the voevoda of Ufa, for the summary execution. ${ }^{46}$ By modern standards this act on the part of loyal Bashkir leaders may seem treasonous but considering the circumstances of the time it was based on much more practical reasons and completely consistent with other imperial experiences. Upon capturing the rebel leaders, the loyal party could have killed them but they preferred to send them to Ufa to prove their loyaltie, ingratiate themselves with the authorities, and possibly receive some reward.

The size of the rebellion was frightening for the Russians who had always been suspicious of even the most minor disturbances and the rebellion was certainly not confined within the borders of Russia. During this war some Bashkirs approached the Kalmyks' khan and

\footnotetext{
${ }^{44}$ Menzele and Ufa were attacked. Kungur was captured and burned down. Neviansk and Dalmatovsk monasteries were razed. Many other smaller settlements were destroyed by the rebels as well. I. G. Akmanov, "Vosstanie 16621664 gg." in Bashkirskaia Entsiklopediia, v.2, ed., I. G. Akmanov and Aznagul Uruskulov, (Ufa: Nauchnoe Izdatel'stvo, 2005), 135.

${ }^{45}$ Aznagul Uruskulov and Bekzian Toktamyshev were from the Sibir doroga and they personally led negotiations with the descendants of the Siberian Khans who were noble enough because they were also the descendants of Genghis khan. Bashkir leaders tried to persuade them to lead and to unite Bashkirs against the Russians. I. G. Akmanov and Aznagul Uruskulov, ed, Bashkirskaia Entsiklopediia, v. 1 (Ufa: Nauchnoe Izdatel'stvo, 2005), 75 and 408.

${ }^{46}$ Materialy po Istorii Bashkirskoi Istorii, part 1, Bashkirskie Vosstaniia v 17 i Pervoi Polovine $18 v v$. (Moskva\&Leningrad: Izdatel'stvo Akademii Nauk SSSR, 1936), 164-165.
} 
the descendants of Kuchum Khan in Siberia. For example, Sary Mergen sent his deputies to the Kalmyk khan for military support. ${ }^{47}$ This was alarming for the Russians because the Kalmyks were the Bashkirs' traditional foes and their services were valuable for the Russians. Nothing came out of it. Another Bashkir leader, Arslanbek Bakkin, sent his representative to Kuchuk Khan, the grandson of the last Sibir khan, Kuchum, and asked for help against the Russian government and in return Bashkirs would submit to his authority. This mission also failed. ${ }^{48}$ Bashkir leaders also conducted a number of negotiations with the Crimean Tatar khan who was also aware of the developments in the region thanks to the news brought by Bashkir envoys, but with no success. These were the attempts by the Bashkir rebel leaders to get rid of Russian poddanstvo (citizenship) and search for another protector. But by this time the Russians were too strong to be intimidated by any usurper.

Bashkirs during this early period of Russian contact were perfectly suitable for the acephalous community in which there was no specific leadership and political organization. Order and peace was provided by able-bodied men who enforced the communal order through the justified use of force. Since there was no central authority the groups defended their rights and privileges through feuds. Raiding was a part of daily life but these raids were not arbitrary but to defend the rightful claims like pasturelands or herds. ${ }^{49}$ Bashkirs on this basis raided not only Kalmyks or Kazakhs, their immediate steppe neighbors, but also settled peoples and other Bashkirs as well. Under the circumstances the order-loving Russian authorities found it impossible to tolerate such anarchistic mode of behavior.

\footnotetext{
${ }^{47}$ Materialy po Istorii Bashkirskoi Istorii, part 1, Bashkirskie Vosstaniia v 17 i Pervoi Polovine $18 v v$. (Moskva\&Leningrad: Izdatel'stvo Akademii Nauk SSSR, 1936), 163.

${ }^{48}$ N. V. Ustiugov, "Bashkirskoe Vosstanie 1662-1664 gg." Istoricheskie Zapiski, 24 (1947), 81-82

${ }^{49}$ For a detailed account of acephalous societies see Paul Georg Geiss, Pre-Tsarist and Tsarist Central Asia: Communal Commitment and Political Order in Change, (Routledge: New York, 2003), 8.
} 
This war became also a model for future Bashkir wars in many respects. First and foremost Bashkirs lacked central leadership. They suffered from the lack of a common front against the Russians, and even worse some of them, especially those who felt the military might of the Russians to be stronger, remained loyal to the government. As part of their tribal nature, there were too many distracting elements. The southern and western Bashkirs were primarily interested in improving their defenses against Kalmyks and they did everything to attract other Bashkir groups to their cause while the northern and eastern Bashkir groups wanted to fight against Russians.

The reasons for the collapse of the rebellion anticipated future rebellions and their failures as well. The Bashkir society by that time was divided into two camps. The "loyal" Bashkirs benefited from the Russian presence in Bashkiria and were rewarded generously by the Russians for their services to the Russian state. On the other side were those Bashkirs who lost from the Russian presence in the region. They were mostly from the eastern and southern parts of Bashkiria and they suffered most from the Russian presence in the region and the overwhelming Russian fortification system which effectively barred them from the seasonal migration.

Quite naturally Russians would be victorious in the long run and there was no practical use to draw the wrath of the authorities upon themselves by joining or supporting, even if surreptitiously, the rebellious groups. Another point is that predominantly nomadic Bashkirs had not developed any national identity by that time but remained dependent upon the tribal loyalties. It paid more to be loyal than to resist and the crushing of rebellious Bashkir tribes offered to the loyal Bashkirs more pasturelands and more material benefits. Not surprisingly Russian authorities exploited these frictions well by promising to distribute the properties of the 
rebellious Bashkirs to loyal ones. It must be underlined that the Russian control of the region was not exclusively destructive for all Bashkirs since at least some Bashkirs gained land from Russians. It was not simply that the Russians only seized land.

In these conflicts, not all of the Kalmyks threatened Bashkirs. Some Kalmyk leaders, mainly Daishi, a contender for power among Kalmyks, against the newly elected and devoutly loyal Puntsuk Khan, supported the Bashkirs' endeavor. They even attacked Russian positions with Bashkirs and provided haven for the fleeing Bashkir groups before the Russian troops. ${ }^{50}$ In the winter of 1663, 1500 Bashkir households reached safety among Kalmyks for which Kalmyks were heavily reprimanded by the Russian officials on the grounds that they (Kalmyks) forgot their shert (oath) to the great Monarch' (Tsar) to be his eternal slaves. ${ }^{51}$

The steppe politics were more complicated than it may seem. There were many different variables and factors that determine the decisions of leaders. They were not completely sure of the loyalties of their tribesmen because loyalties could shift rapidly and the tribal rules among the nomads in the steppe region could not be determined precisely because each tribe contained many power groups and tribal chiefs were in fact not all powerful leaders but figures of compromise. Accordingly, those 1500 Bashkir households among Kalmyks would be forced to abandon their new patrons due to their position as outsiders within the Kalmyk camps and they were held in contempt by the new patrons and humiliated at every occasion. So they left the Kalmyk camp soon after they joined it and begged for mercy from the Russian authorities.

One reason for the lack of cooperation among Bashkirs in their war effort against Russian was that by the 1660s there had emerged radical changes in the life styles of Bashkirs. Those

\footnotetext{
${ }^{50}$ Michael Khodarkovsky, Where Two Worlds Met: The Russian State and the Kalmyk Nomads, 1600-1771 (Ithaca and London: Cornell University Press, 1992), 98.

${ }^{51}$ B. A. Aznabaev, Integratsiia Bashkirii v Administrativnuiu Strukturu Rossiiskogo Gosudarstva (Vtoraia Polovina 16-Pervaia Treti 18 vv.), (Ufa: RIO BashGU, 2005), 109.
} 
who lived nearest to the Russians, especially in Kazan doroga, had already started a sedentary life and abandoned their nomadic life style to a great degree. Accordingly they had lost their mobility due to the fact that they had a village to defend rather than an elusive herd in the steppe area. So Bashkirs failed to develop a common strategy.

Ironically, the lack of a common leadership was the main reason for the initial Bashkir success against Russians. The Russian authorities always believed that in the nomadic world the purchase of the leader would guarantee the loyalties of the lower class people in those tribal groups. Accordingly when they failed to purchase the loyalty of the tribal leadership they preferred to contain those leaders by demanding amanat, taking of hostages. If this policy failed, they eliminated the disobedient leaders by inciting conflict and boosting factions within the tribe. In the case of war the simplest way to suppress armed clashes would be to assassinate the rebellious leader. This policy by and large did not work against Bashkirs because there was not one single leader of these wars. In each case there could be found at least half a dozen different leaders and it was impossible to kill all of them at the same time. The most prominent leader of the 1662-1664 rebellion was a man called Sary Mergen. Mergen was killed by the Russian punitive forces in 1663 but his death in European Bashkiria did not stop the Bashkir war effort east of Urals because there were many other leaders who emerged to continue Bashkirs' war efforts.

The Russian demand of amanats from Bashkirs, even from the loyal Bashkirs (dobrykh liudiei) for the first time in 1663 proves the fact that there was now an unbridgeable crack between Russian and Bashkir mutual understanding. ${ }^{52}$ The system of amanat was available in eastern Bashkiria where Russian military might had brought Siberian Bashkirs to their knees.

\footnotetext{
${ }^{52}$ I. G. Akmanov, ed., Istoriia Bashkortostana s Drevneishikh Vremen do Nashikh Dnei, v. 1, (Ufa: Kitap, 2007), 147; Materialy po Istorii Bashkirskoi Istorii, part 1: Bashkirskie Vosstaniia v 17 i Pervoi Polovine $18 v v$. (Moskva\&Leningrad: Izdatel'stvo Akademii Nauk SSSR, 1936), No. 56 and 60.
} 
Such a thing was unquestionable in western and southern Bashkiria because they recognized Russian suzerainty voluntarily. On the other hand, the conquered eastern Bashkirs had to pay four times higher Iasak than those western and central Bashkirs. Siberian Bashkirs paid 1 ruble person while their western brethren paid only 25 kopeck which was further reduced to five martens per person. ${ }^{53}$

Boris Nolde contends that major reason for the outbreak of war in 1662 was the gradual penetration of Russian government into the Bashkir lands, violating the terms of the land charter granted by Russian Tsar Ivan the Terrible. ${ }^{54}$ Until the 1660s Bashkirs occasionally and in a limited sense protested these Russian intrusions, as noted above. A detail must be noted here. Bashkirs were most of the time portrayed in Imperial or Soviet historiography as savage, primitive or underdeveloped people. In fact these people were well aware of their rights and showered Russian authorities in the regions with petitions about the injustices committed by the officials, protesting land seizures and violations of the terms of their clientage and votchina rights with the Russian state. In one of these, dated 1627, Bashkirs of Bailarskii volost in Kazan doroga complained about a certain Russian service person, "Batlaev, entering their votchina, barring the votchina and making them buy martens and honey to pay their Iasak." ${ }^{, 55}$ In another, dated 1663, a Bashkir delegate to Prince A. M. Volkonskii, the voevoda of Ufa at the time, complained about their loss of status and votchinas which were grabbed by service people (sluzilye liudi) in the area. ${ }^{56}$ The correspondence between Russian voevodas of the Urals is full

\footnotetext{
${ }^{53}$ A. A. Novoselskii and N. V. Ustiugov, ed., Ocherki Istorii SSSR, Period Feodalizma (Moskva: Izdatel'stvo Akademii Nauk, 1955), 805.

${ }^{54}$ Boris Nolde, "Usmirenie Bashkirii" Vatandash, 2, (2000), 102-103.

${ }^{55}$ I. G. Akmanov, "Vosstanie 1662-1664 gg. - Pervoe Massovoe Dvizhenie v Bashkirii" in Krest'ianstvo $i$ Krest'ianskoe Dvizhenie v Bashkirii v 17 - Nachale 20 vv. ed., Kh. F. Usmanov, (Ufa: 1981), 50.

${ }^{56}$ Materialy po Istorii Bashkirskoi Istorii, part 1, Bashkirskie Vosstaniia v 17 i Pervoi Polovine $18 v v$. (Moskva\&Leningrad: Izdatel'stvo Akademii Nauk SSSR, 1936), 170-173. In this document in fact Bashkirs are summarizing their many other complaints. For example they claim that Russian local officials, Mikita Iur'ev, Ivan
} 
of such complaints by Bashkirs in their petitions and they demand an end to the officials' wrongdoings. ${ }^{57}$

The great rebellion of 1662-1664 was not the result of a haphazard decision by the Bashkir leaders to renounce Russian patronage. In the depths there were radical reasons and Russians' treatment of Bashkirs as simple savages who could be squeezed with impunity was a grand delusion on the part of Russians. The local officials' corruption and repressive manners were universal which was confirmed by Imperial and Soviet or post-Soviet historians. The role of the central government in the emerging Bashkir disgruntlement is generally portrayed as one of helplessness due to the fact it was too weak in the region and had limited means to keep local officials' excesses or injustices under control.

Though these are correct, this is only one side of the coin. The Russian government also actively supported land seizures by Russian officials for purposes of establishing defensive points in the region during the second half of the sixteenth and seventeenth centuries. ${ }^{58}$ The land seizures and colonization in Bashkiria grew by leaps and bounds. For example, in the lands immediately surrounding Ufa, 25 versts ${ }^{59}$ of land from all directions were seized from Bashkirs and distributed to the Russian officials. ${ }^{60}$ The land seizures by the monasteries were also considerable. Though these monasteries were allowed by the government they went beyond the

Pavlov and Ivan Kulakov, are kidnapping their wives and children and selling them into slavery or spending night with their wives in the Bashkir tents, grabbing the best Bashkir horses.

${ }^{57}$ Materialy po Istorii Bashkirskoi Istorii, part 1, Bashkirskie Vosstaniia v 17 i Pervoi Polovine $18 v v$. (Moskva\&Leningrad: Izdatel'stvo Akademii Nauk SSSR, 1936), 70-72.

${ }^{58}$ Russian peasants were forbidden to settle in the Bashkir lands during this period and they were considered outlaw by the Russian government.

${ }^{59} 1$ verst is 1.06 kilometres. It is nearly $2 / 3$ mile.

60"'Tekst "Otvodnoi Knigi po Ufe" (1591/92-1629 gg.)" in Iz Istorii Feodalizma i Kapitalizma v Bashkirii - Stati ed. S. M. Vasil'eva, (Ufa: 1971), 261-267; I. G. Akmanov, "Vosstanie 1662-1664 gg.: Pervoe Massovoe Dvizhenie v Bashkirii" in Krest'ianstvo i Krest'ianskoe Dvizhenie v Bashkirii v 17 - Nachale 20 vv. ed., Kh. F. Usmanov, (Ufa:1981), 45-67. 
limits set by the government and enlarged the amount of monastic control of the land on their own volition.

The most prominent leaders of the 1662-1664 rebellion were Sary Mergen (from Ufa uezd), Arslanbek Bakkin and Gaur Akbulatov. Sary Mergen was the leading figure who was killed by the Russian punitive forces in 1663 . He was the best known Bashkir leader of this episode of Bashkir history. He was a very rich man who could have attracted Bashkirs to his side thanks to his material wealth and leadership qualities. We know less about other leaders, however, except the fact that Arslanbek Bakkin took over leadership after the death of Sary Mergen. All these three leaders were from the Bashkir nobility and very influential social leaders as well.

Sary Mergen was an able leader who revolutionized the Bashkir mindset by persuading his fellow Bashkirs to open negotiations with Kalmyks. For this purpose he sent a delegation to Kalmyk leaders to conclude an alliance against Russians. ${ }^{61}$ This was a radical break with the past and some of the Bashkirs for the first time looked for some sort of sovereignty by breaking their ties with the Russian lord. Despite this, the mainstream Russian and Soviet historiography did not hesitate to call these wars rebellion. ${ }^{62}$ Sary Mergen's leadership qualities notwithstanding, he never fully attracted all Bashkir groups to his side. One reason for this was the internal struggle within the Bashkir society. The tribal elders had no absolute power over the members of their clans and they had to walk on a tightrope with another player at the other end of the rope.

\footnotetext{
${ }^{61}$ Materialy po Istorii Bashkirskoi Istorii, part 1, Bashkirskie Vosstaniia v 17 i Pervoi Polovine $18 v v$. (Moskva\&Leningrad: Izdatel'stvo Akademii Nauk SSSR, 1936), 161; I. G. Akmanov argues that Kalmyks did not send their support to Sary Mergen.

${ }^{62}$ There is a bunch of literature about this labeling. See N. V. Ustiugov, Bashkirskoe Vosstanie, 1737-1739 gg. (Izdatel'stvo Akademii Nauk SSSR: Moskva-Leningrad; 1950); R. N. Zinurov, Bashkirskie Vosstaniia i Indeiskie Voiny: Fenomen v Mirovoi Istorii, (Gilem: Ufa, 2001); I. G. Akmanov, Bashkirskie Vosstaniia (Ufa: Kitap, 1993) I. G. Akmanov is the most productive scholar about the Bashkir rebellions but he fails to give a detailed account of daily lives of Bashkirs of the time and their reasons why to follow a few notables. His other defect is that he is from the old Soviet school which championed the friendship of peoples.
} 
Despite Bashkirs' growing discontent with the Russian policies and the manners of the local Russian officials, the level of discontent was not the same everywhere within Bashkiria. Those who preferred to side with Russians against their Bashkir brethren had clear and absolutely legitimate reasons to do so. At least the Bashkirs of Nogai Doroga mostly preferred the Russian side because their territories had been most threatened by Kalmyks. Despite all the Russians' shortcomings, they nevertheless seemed more reliable and more predictable and more willing to negotiate with Bashkirs than Kalmyk raiders. ${ }^{63}$ But when Sary Mergen sent his delegation to the Kalmyks he knew the fact that Bashkirs of Sibir doroga was least affected from the Kalmyk raids and they were much less vulnerable to their attacks. ${ }^{64}$

This was the greatest dilemma of the Bashkir rebellious leadership. They could not wage a war against Russians alone. They needed allies but only viable allies around were Kalmyks who were also divided among themselves. Their alliance alienated other Bashkir groups and prevented Sary Mergen from forming a united front against the central government. There was an incompatibility between goals and means to achieve those goals. This incompatibility led to the rift within the leadership of the war party, and while Sary Mergen endeavored to continue the struggle, Arslanbek Bakkin chose to negotiate with the authorities. ${ }^{65}$ This rift cost them time and initiative since Bashkirs were not united and short of means to conclude this war successfully. Their advantage was time. Until the Russian government gathered and deployed forces against

\footnotetext{
${ }^{63}$ Some Bashkir Tarkhans (They are lesser nobles who served in the military but they were exempted from paying Iasak) of the Nogai Doroga, Ishmukhamed brothers, Denevei Davletbaev, Karabash Uteev from Kazan Doroga actively fought against anti-Russian Bashkirs.

${ }^{64}$ I. G. Akmanov states that Kalmyks flatly rejected Sary Mergen's attempt to approach while Zinurov contends that Kalmyk response to Sary Mergen was not known. In either case Kalmyk-Bashkir alliance did not materialize which gave Russians a respite.

${ }^{65}$ I. G. Akmanov, Bashkirskie Vosstaniia (Ufa: Kitap, 1993), 97-98.
} 
them, Bashkirs had to achieve their best and during the first six months of the war they were successful. ${ }^{66}$

Bashkirs occasionally gained some success against the Russian regular army as in the case of the battle that took place in the summer of 1663 when some 30 Russian soldiers were killed and many others including their commander were wounded. ${ }^{67}$ But the same Russian commander after a few weeks of recuperation returned to his army and stormed Bashkir settlements and villages. The Bashkir rebel leader Uruslan Bakkin was killed by the same Russian expeditionary force in an ambush and his family was also decimated in the spring of 1664. ${ }^{68}$ The balance of power was definitely on the side of Russians. The Bashkirs fought hard to get the most meager benefits, yet even then Russian forces could make a strong comeback and get rid of the Bashkirs' meager success at the first opportunity.

One of the salient features of this rebellion is that the leadership was almost totally monopolized by the Bashkir tribal aristocracy. They dreamed of creating a Bashkir khanate led by a Chingisid who could legitimately unite all Bashkirs. The Bashkir religious ulama played only a secondary role. They actively supported war effort in an indirect way by leading negotiations between Bashkir leaders and other potential supporters of Bashkirs. One of them, Kara Duvani Bakaik Abyz, was dispatched to Crimean Khan, a Chingisid himself, to get assistance. ${ }^{69}$ Such a choice from the religious class was meaningful because most probably Bashkir leaders expected a Muslims scholar to be more influential by playing on the religious sentiments of Crimean Tatars.

\footnotetext{
${ }^{66}$ They had captured or destroyed at least seven kreposts.

${ }^{67}$ I. G. Akmanov, ed., Istoriia Bashkortostana s Drevneishikh Vremen do Nashikh Dnei v Dvukh Tomakh v. 1, (Ufa: Kitap, 2007), 148.

${ }^{68}$ N. V. Ustiugov, "Bashkirskoe Vosstanie 1662-1664 gg.” Istoricheskie Zapiski, 24 (1947), 104-105.

${ }^{69}$ N. V. Ustiugov, “Bashkirskoe Vosstanie 1662-1664 gg.” Istoricheskie Zapiski, 24 (1947), 66.
} 
Soviet historiography contends that these wars were not directed against the relatively small numbers of Russian peasants who settled in the region, but primarily against state officials. In Tipeev's view, these were voevodas, generals, officers, pomeshchiks (gentry landowners who held land on condition of service), traders, Rostovshchiks (literally usurer, money lender) and their system of administration in Bashkiria. ${ }^{70}$ The leading historian of these wars and author of a number of several books about the issue, I. G. Akmanov, states that the Bashkirs' war effort was against Russian authorities, monasteries and dvoriane. The Russian laboring masses were caught in crossfire and their settlements were burned down by armed groups, however not all settlements were destroyed by Bashkirs. ${ }^{71}$ There are problems with these arguments. In the first hand, they never give a list of Russian settlements before and after the wars. There seems to be no data about the number of Russian settlers before and after the wars. There are also problems with the archival materials. These authors predominantly rely on the accounts of Russian officials in their area whose impartiality is highly dubious.

Even though various scholars call this 1662-64 war as the first great Bashkir rebellion against Russia, it was no doubt supported and actively joined by other non-Russian peoples of the region. Tatars, Chuvash, Mansi, Mari and even prisoners of war, Litovski people, who had been captured during Russo-Polish wars of the 1650s and exiled to the region, actively took part in this war. ${ }^{72}$ Their contribution to the war effort was in fact a reflection of the failures of the Russian policies towards the nationalities. The Bashkirs initiated this war because their life style and mobility was threatened by the central government. As for other more sedentary groups

\footnotetext{
${ }^{70}$ Sh. I. Tipeev, Ocherki po Istorii Bashkirii (Ufa: Bashkirskoe gos. izd-vo, 1930), 43.

${ }^{71}$ I. G. Akmanov, "Vosstanie 1662-1664 gg.: Pervoe Massovoe Dvizhenie v Bashkirii" in Krest'ianstvo $i$ Krest'ianskoe Dvizhenie v Bashkirii v 17 - Nachale 20 vv. ed., Kh. F. Usmanov, (Ufa:1981), 47.

${ }^{72}$ N. V. Ustiugov, “Bashkirskoe Vosstanie 1662-1664 gg.” Istoricheskie Zapiski, 24 (1947), 74.
} 
their livelihood was endangered by government's increasing financial demands originated from the Russo-Polish war of 1654-1667.

The rebellion was not only taking place in the frontier. It was in fact an extension of rebellion that took place in the very heart of the Muscovite system. The Kolomenskoe riot of 1662 in Moscow was the result of the government's sweeping monetary policies like issuing copper money and exorbitant fiscal demands from the tax payers. The result was a skyrocketing inflation and a radical decline in the incomes of the laboring masses of Moscow. ${ }^{73}$ The same problem had struck the frontier as well. Even though the rioting in Moscow was crushed within days, more distant frontier areas remained tumultuous for another two years. The exact amount of the increased Iasak on the shoulders of Bashkirs is not known since the archival materials about the issue are still not discovered but some Bashkir families fled to the Kalmyks to escape the harassment of Russian tax officials. ${ }^{74}$ The result was a loss of revenue on the part of the government and an increasing loss of confidence towards Russia on the part of Bashkirs.

There was another side of the coin as well in this flight. Russians were considered worse than Kalmyks, Bashkirs' traditional enemies. This was the most important message of this rebellion which Russian authorities could derive. Kalmyks were still an uncontrollable and belligerent group of people against whom Russian authorities had to manage relations very carefully. The possibility of an alliance between rebellious Bashkirs and Kalmyks could have devastating effects on the Russians. One of the salient features of this kind of frontier relations is

\footnotetext{
${ }^{73}$ Sergei M. Soloviev, History of Russia, vol. 21: The Tsar and the Patriarch, (Academic International Press, 2000), 2-5 (Translated by T. A. Smith); Soloviev fails to give a detailed account of the reasons of the outbreak of his riot. For more details see, David F. Burg, A World History of Tax Rebellions: An Encyclopedia of Tax Rebels, Revolts, and Riots from Antiquity to the Present (New York: Routledge, 2004), 220-221; George Vernadsky and Michael Karpovich, A History of Russia: The Tsardom of Moscow 1547-1682 (New Haven: Yale University Press, 1959), 532; It is better known as copper riot. See; Maureen Perrie, "Popular Revolts" in The Cambridge History of Russia: From Early Rus' to 1689, ed., Maureen Perrie, D. C. B. Lieven, Ronald Grigor Suny, (New York: Cambridge University Press, 2006), 604-605.

${ }^{74}$ N. V. Ustiugov, "Bashkirskoe Vosstanie 1662-1664 gg.” Istoricheskie Zapiski, 24 (1947), 58-60.
} 
that the central government hired one nomadic group against the other. To the degree the central government succeeded in this goal it would better be able to control such areas. The overall situation was not simply Russians versus indigeneous peoples of all sorts be it Bashkirs or Kalmyks. They simply intervened as a new power in the steppe politics and became a party. Their policies seemed unacceptable for many natives and drove them closer to each other but in fact Russians were much more lenient to those peoples than they were to each other. It is ironic that those natives who took refuge in the camps, escaping from the Russian excesses many times regretted fleeing to the Kalmyks. ${ }^{75}$

The Bashkirs in the 1662-1664 rebellion were not militarily crushed by the Russians but they sued for peace in return for certain concessions from the Tsar. The oppressive Voevoda of Ufa, A. M. Volkonskii, was replaced and the Bashkirs were again granted votchina rights. Yet this war sealed the fate of the Bashkirs despite their success. They had been defeated in their larger goal: getting rid of Russian suzerainty. They could not boast any more that they had voluntarily accepted Russian patronage. ${ }^{76}$ They attempted to find another patron when the Russian government increasingly had become intrusive. They in vain tried to alter the situation but Russians proved too strong for them. It had finally become clear that the two radically distinct cultures could not coexist any longer. They would either go their own ways or the weaker one would become more like the other. In this case the Bashkirs had nothing to do but to change their own traditional ways.

By 1663 the rebellion in central Bashkiria was over when the leading Bashkir rebel, Sary Mergen, was killed, but in the eastern Bashkiria rebellious activity continued a year longer.

\footnotetext{
${ }^{75}$ Materialy po Istorii Bashkirskoi Istorii, part 1: Bashkirskie Vosstaniia v 17 i Pervoi Polovine $18 v v$. (Moskva\&Leningrad: Izdatel'stvo Akademii Nauk SSSR, 1936), 160.

${ }^{76}$ Roger Portal, Russes et Baćkirs: Aux XVII et XVIII Siëcles(1662-1798), 30 ; It's Russian translation is available at http://kraeved.opck.org/biblioteka/ural/ural_xviii_v/ural_xviii_v.pdf accessed on 7 April 2008
} 
However in the areas where the rebellions ceased to exist, authorities' terms of the peace were generous for Bashkirs. First of all the Russian Tsar Alexei personally received the delegates of the formerly rebellious Bashkirs, a gesture that could be interpreted as the Tsar's benevolence and his intentions to honor Bashkirs. In addition, the Russian government replaced the infamously corrupt Ufa voevoda Volkonskii with a more honest voevoda. The tsar also reaffirmed the conditions of Bashkir vassalage which had been designed in 1557 prohibiting the further seizure of Bashkir lands and punishing those guilty of abuses in the collection of Iasak. ${ }^{77}$ This was a symbolic victory for the rebellious Bashkirs in the sense that the conditions that had led to their rebellion had barely been reversed but the Russian settlements continued to grow in the region. Bashkirs for another two decades continued to hope that the Russian land seizures would cease.

This war indicated that neither Russians nor rebellious Bashkirs were strong enough to achieve their goals alone. But Bashkirs despite all their shortcomings gained minor concessions. This was a tactical success for Bashkirs but a strategic defeat. The rebel forces attempted to evict Russians from Bashkiria but failed. They only delayed the consolidation of Russian authority in the region for another 20 years and they were in no position to prevent the influx of the settlers into their territory. ${ }^{78}$

Considering the results of this first massive rebellion, Bashkirs believed that by resorting to arms they could protect their interests. The Russians compromised in the face of the difficulties they had in suppressing the rebellion by means of force. In fact Russian's concessions meant only a partially retreat. Land seizures and the arbitrariness of the local agents of the tsar continued unabated.

\footnotetext{
${ }^{77}$ Zufar Enikeev, Pravovoi Status Bashkortostana v Sostave Rossii, Istoriko-Pravovoe Issledovanie (Ufa: Gilem, 2002), 71.

${ }^{78}$ I. G. Akmanov, Bashkirskie Vosstaniia 17-Pervoi Treti 18 v. (Ufa: Bashkirskie Gosuniversitet, 1978$), 36$.
} 
Still the limited success of 1662-1664 war gave Bashkir groups a hope of success if they did not repeat the same mistakes again. Such a scheme required complex planning and preparation but the centrifugal character of the Bashkir life made it impossible. This episode of the Russo-Bashkir relations was a turning point from another point of view. During the second half of the sixteenth and the first half of the seventeenth centuries the relations between Russian government and Bashkir groups was based on mutual trust. This tendency was so dominant that Bashkirs were not even told to send amanat (hostages) to Ufa at all. ${ }^{79}$ This period, however, ended bleakly after the 1662-1664 war and the Bashkirs always treated even the slightest Russian policy changes with utmost suspicion and hostility.

\section{Muscovite-Bashkir conflicts, 1681-1684 and 1704-1711}

The second wave of the Bashkir rebellions started in 1681 on the pretext that the Russian government ordered their conversion to Christianity. ${ }^{80}$ This time the uprising was led mainly by a religious scholar called Seit. ${ }^{81}$ So in appearance the reasons for the uprising seemed religious. The governmental ukaz in 1681 ordered the forceful conversion of non-Orthodox population of Middle Volga region ${ }^{82}$ which caused another great wave of migrations by the peoples of the middle Volga. This decree in fact had nothing to do with the Bashkirs who were still at the fringe of the Russian empire. The Russian colonial policy in the Urals and Siberia in the

\footnotetext{
${ }^{79}$ Only the easternmost Bashkirs, since they cooperated with the Sibir Khanate against Russians, were required to send Amanat to Ufa voevode.

${ }^{80}$ In fact there was no such a thing relating to Bashkirs. The Tsar's ukaz was confined to middle Volga region.

${ }^{81}$ There is not much information about Seit. Allen J Frank argues that he was a Chinggisid, a khan and a Sufi mystic who was considered a saint by fellow people. His fate, whether he was killed, captured or escaped is not known. Allen J. Frank, Islamic Historiography and "Bulghar" identity among the Tatars and Bashkirs, (Leiden [Netherlands]\& Boston: Brill, 1998), 24.

82 Pol'noe Sobranie Zakonov Rossiiskoi Imperii, v.2 No: 867. (From now on PSZ)
} 
seventeenth century could be described as a policy of indirect rule where the local elite was kept in place and their privileges were not threatened in principle. ${ }^{83}$

The reality was quite different. The government had abandoned its policy of noninterference in the internal affairs of the region as of the mid-1670s. The chronic conditions that led to the 1662-1664 Russo-Bashkir war repeated themselves. The same arbitrariness of the Russian elite in the region went undiminished. To make matters worse the rumors of forced conversion of the Bashkirs accelerated war. The leadership of the war for the Bashkirs as noted was a mullah. This was quite surprising for a nominally Muslim group where the religion played the least effective role in the daily life. ${ }^{84}$

The first armed conflict started in Sibir and Nogai Dorogas in the summer of 1681 after a massive Iighin, mass meeting, was held in May of that year. Mulla Seit sent most possibly his disciples to different Bashkir districts to incite population to rise against forced conversion to defend their religion. One of them, a certain Il'metaika, an abyz ${ }^{85}$ himself, was caught on the charges of instigating rebellion mentored by Seit Mulla by the Russians and transferred to Ufa for execution. ${ }^{86}$ By the spring of the following year the rebellion had a massive character partly because of the military weakness of the government in the region.

\footnotetext{
${ }^{83}$ Nancy Shields Kollmann, "Society, Identity, and Modernity in Seventeenth Century Russia" in Modernizing Muscovy: Reform and Social Change in Seventeenth-Century Russia, ed., Jarmo Kotilaine, Marshall Poe, (London \& New York: Routledge, 2004), 421.

${ }^{84}$ For additional information about Seit Safirko, see; I. G. Akmanov, Bashkirskie Vosstaniia 17-Pervoi Treti $18 v$. (Ufa: Bashkirskie Gosuniversitet, 1978), 45: Rychkov argues that Seit was a Starshina rather than a mullah. P. I. Rychkov, Topografiia Orenburgskoi Gubernii (Ufa: Kitap, 1999), 53; Bashkirs' religious fervor may seem perplexing for such an under-Islamicized community. In fact the attempt was closely related with protecting Bashkir way of life against an alien, Orthodox Christian intruder. To convert to Christianity would mean succumbing to the alien ways, manners and institutions. The Orthodoxy represented in this sense the other and Islam increasingly came to mean Bashkir traditions, customs and ways. However this was only in the making which was not all clear to all segments of the society.

${ }^{85}$ Abyz is a person who has learned the Koran by heart; any learned man. They are a proof that there was a serious Islamic education in Bashkiria.

${ }^{86}$ I. G. Akmanov, Bashkirskie Vosstania (Ufa: Kitap, 1993), 111; R. N. Zinurov, Bashkirskie Vosstaniia i Indeiskie Voiny: Fenomen v Mirovoi Istorii (Ufa: Gilem, 2001), 154; Allen J. Frank, Islamic Historiography and "Bulghar" Identity among the Tatars and Bashkirs, (Leiden [Netherlands]; Boston : Brill, 1998), 24; The interesting point in
} 
Between August 1681 and July 1682, the forces of Seit invaded a number of Russian villages, attacked larger settlements and besieged Ufa. In the meantime a large Russian force sent from Tiumen met Seit and his forces. Both sides' casualties were high. Possibly Seit himself was wounded but Russians failed to exterminate Seit's forces in a pitched battle. ${ }^{87}$

The inability of the authorities to smash the rebellion heartened dormant Bashkir groups to join the rebellion and the dimensions of war changed. The rebellion had started to defend religion but it turned out to be after the initial successes an anti-Russian and anti-colonial war. ${ }^{88}$ Bashkirs attacked the most hated establishments in the middle of the Bashkir lands: the TransKama defensive line, the forts and settlements created by Stroganovs in Bashkiria; and Ufa was attacked for the first time which shows the size of the conflict. The government was utterly unprepared for such a massive war and was forced to relinquish the Ukaz relating to the conversion of the peoples to Christianity.

In an ukaz dated June 8,1683 , the charter from the Tsars Ivan and Peter called for an end to the armed hostilities stating that "war mongers spread the false news that the government attempted to convert inovertsy, adherents of other faiths, against their will. There was never such a thing and there is not any at the time and never suspect such a thing."89

This was good enough for some of the Bashkir leaders like Kuchuk Iulaev, and many of the newcomers to the region who had escaped forced conversion. They ceased to fight and asked

this insignificant individual called Ilmetaike, whose ethnic background whether Tatar or Bashkir is not known to us, is that the Islamic sensitivities of the people in the region reached to a considerable level so much so that indigenous people are ready to bear arms in defense of their religion and Muslim clergy started to play a significant role in the Bashkir society.

${ }^{87}$ Materialy po Istorii Bashkirskoi Istorii, part 1, Bashkirskie Vosstaniia v 17 i Pervoi Polovine $18 v v$. (Moskva\&Leningrad: Izdatel'stvo Akademii Nauk SSSR, 1936), 208.

${ }^{88}$ Bashkirs were helped by animistic Finnic groups like Maris, Udmurts and Turkic Chuvash.

${ }^{89}$ F. Kh. Gumerov, ed., Khrestomatiia po Istorii Bashkortostana Dokumenty i Materialy s Drevneishikh Vremen do 1917 Goda. Volume 1, (Ufa: Kitap, 1996), 114. 
for chelobit'e (literally petition). ${ }^{90}$ Where government failed to impose its will with armed force it won with concessions and divided Bashkir forces and leadership. Seit refused to abandon his struggle because the conditions required more than the abandonment of the forced conversion. ${ }^{91}$ The fighting continued until the summer of 1684. Briefly Kalmyks joined Bashkirs in the meantime and they jointly attacked a number of Russian positions in Bashkiria until the time Russian authorities managed to persuade Kalmyk leader Ayuki Khan to return back to Kalmyk lands. In the end Russian authorities gave way and promised to stop seizure of Bashkir lands, reaffirmed Bashkir votchina rights, removed the voevod of Ufa, Korkodinov, for his maltreatment of Bashkirs, and finally promised to put an end to the forceful Christianization of inovertsy. This last item was good enough to weaken the arguments of Seit to continue struggle. No source mentioned his name anymore. ${ }^{92}$

This war was a success for the Bashkirs in the short run. They received what they wanted but it was also a partial failure for them and reasons for their failure were in fact harbingers of the transformation of Bashkir society. They had failed to create a united front against Russians and they had legitimate reasons for their failure. In the first place not all Bashkirs had been affected from the Russian policies at the same level. There was an uneven economic transformation in the Bashkir society. While by this date Eastern Bashkiria (Sibirski Doroga)

\footnotetext{
${ }^{90}$ The government's promise to stop conversion was one factor but the Bashkir leadership had other motives to accept Russian concessions as well. First of all their already developing villages could be destroyed by the Russian punitive forces and this could create greater problems for the Bashkir leaders who were only tenuously able to control their own fighters. The envoy of Kuchuk was accepted by the new leadership in Moscow: Ivan and Peter. The Bashkirs, in return for their pardon, promised to return captives, the robbed-property and to serve the tsars loyally. They even agreed to send Amanat to the Russian authorities as a sign of good faith. See; I. G. Akmanov, ed., Istoriia Bashkortostana s Drevneishikh Vremen do Nashikh Dnei v Dvukh Tomakh v. 1, (Ufa: Kitap, 2007$), 153$.

${ }^{91}$ Former comrade-in-arms, Kuchuk Iulaev, promised Russian authorities to catch and deliver Seit to the authorities. See I. G. Akmanov, Bashkiriia v Sostave Rossiiskogo Gosudarstva 17-Pervoi Polovine 18 Veka (Sverdlovsk: Izdatel'stvo Ural'skogo Universiteta, 1991), 81; This radical switching sides is an evidence of the Bashkirs' tribal ways which still seem far away from a religious and national identity. Such radical moves would make their appearance in Bashkir history throughout the period this essay covers.

92 One Russian traditional policy in dealing with rebels was to assassinate the rebel leader but in Seit's case seemingly they failed to eliminate him.
} 
and Southern Bashkiria (Nogai Doroga) were thinly populated by Russians, the Kazan and Osin doroga had witnessed an increasing sedentarization of Bashkirs and a rising migration into these parts of Bashkiria by Russians and non-Russians. The governmental control here was stronger than Sibir or Nogai dorogas. Not surprisingly Kuchuk Iulaev was from Tam'ianski volost which was located in modern day Meleuz district of modern day Bashkir republic which is only $223 \mathrm{~km}$ from Ufa and it could be reached through Belaia River. ${ }^{93}$ This vulnerable location of Tamianski volost forced Kuchuk Iulaev to abandon armed hostilities against Russians. More radical elements of the Bashkir society who were determined to continue the struggle were left without allies despite short lived Kalmyk cooperation and remained divided.

The result of this war was that Russia was still not strong enough to subdue this belligerent people and it became clear that Bashkirs were in a period of extensive Islamization. The reasons for this are still not clear and there is not any academic work either in Russian or in English relating to this part of the history of Bashkirs. There are no data about the number of Islamic schools and masjids in Bashkiria. There is not any figure about the number of more Islamic Tatar population in Bashkiria who might have had an influence on the Bashkir from the religious point.

It is a universally recognized view that Tatars during the seventeenth century became subject to more severe state repressions than Bashkirs and in desperation Muslim Tatars escaped to Bashkir lands in huge numbers. ${ }^{94}$ But none of these holders of this universal view gives any approximate data about the number of Tatars who escaped and resided in Bashkir lands. No one

\footnotetext{
${ }^{93}$ R. Z. Shakurov, ed., Bashkortostan: Kratkaia Entsiklopediia (Ufa: Nauchnoe Izdatel'stvo, 1996), 558.

${ }^{94}$ Mary McAuley, Russia's Politics of Uncertainty (New York: Cambridge University Press, 1997), 43.
} 
has investigated the specific interactions between Bashkirs and Tatars, nor the influences exerted by one over the other. ${ }^{95}$

Also until recently Bashkir history was not considered as a field of serious concern. The historians in the west mostly focused on Volga Tatars and only superficially mentioned Bashkirs in the most generalized form. Accordingly serious errors were made at times. For example, Alexandre Bennigsen erroneously argues that Bashkirs were subjected to genocide in the seventeenth century by the Russians. ${ }^{96}$ The fact was that the Russian government had neither willingness nor means to do so in that century. Bashkirs had still not been successfully isolated from the outside world and the Russian authorities were still more interested in extracting Iasak payments from the Bashkirs than opening their lands to the systematic colonization of the Russian peasants. The real focus of the Russian state during the second half of the seventeenth century was mostly in Ukraine and against Poland. The real massacre of Bashkirs which reached genocidal proportions took place during the fourth major Russo-Bashkir wars of 1735-1740 (this will be discussed below). But even then when nearly a quarter of the Bashkir population was killed the Russian authorities' main concern was to avoid stirring a Bashkir uprising.

By the end of this period there were sharp differences between the Bashkir community of the $1550 \mathrm{~s}$ and $1710 \mathrm{~s}$. The transition from an acephalous society to patriarchal political community was clear. There was a set enemy, an intruder who seized Bashkir lands and violated the votchina rights, and a mischief maker who planted the seeds of sedition among Bashkir groups by favoring some against the other. Bashkir organization for war was exemplary for an

\footnotetext{
${ }^{95}$ Viktor Aleksandrovich Shnirelman argues that Teptiars evidently originated from a mixed Tatar-Bashkir population. There are conflicting views that Teptiars were not an ethnic group but rather a social estate in Bashkiria. 96 Alexandre Bennigsen and Marie Broxup, The Islamic Threat to the Soviet State (New York : St. Martin's Press, 1983), 24; The same error is also repeated in the following book. The author cited Bennigsen's views without analyzing the validity of the arguments. See Shireen T. Hunter, Jeffrey L. Thomas, Alexander Melikishvili, Islam in Russia: The Politics of Identity and Security (Armonk, N.Y.: M.E. Sharpe, 2004), 16.
} 
acephalous society. The intentions and decision of war were declared in Iighins (mass gatherings) and the masses' support was demanded. Unfortunately there are no records about the details of these lighins. There seems to be no evidence about what they debated and how they persuaded Bashkirs to take arms against Russians. Most probably these lighins were the occasions where leaders employed persuasion rather than coercion to get the support of the people.

By the end of this period the importance of Iighins declined partly because Russian authorities took a hostile attitude toward these occasions. It had also become clear that there would never be any more uniformity of opinion among Bashkirs relating to the fate of the nation thanks to the availability of the pro-Russian elements among the Bashkir tribes. So the last and greatest Bashkir effort of this period to oust Russians from Bashkiria that took place between 1704 and 1711, was decided by a Bashkir minority rather than the masses. Thanks to the competent leadership of a number of charismatic individuals, especially Aldar Isekeev, also known as Aldar Isyangildin, the rebellion took on a massive character. ${ }^{97}$

The immediate reason for the 1704-1711 war was the central government's growing fiscal demands and ingenuity of its officials to invent all sorts of new taxes, (taxes on baths, bees, horse collars, storage rooms, masjids, masjid attendees, etc.). This war was fought in four stages: 1704-1706, 1707-1708, 1709-1710 and 1711. The Russian authorities in the early stages

\footnotetext{
${ }^{97}$ Aldar was one of the best leaders Bashkirs ever had. He was from Burziansk volost, Sibir Doroga, and later the starshina of the same volost. He served in the Russian army with distinction and took part in the Crimean expeditions in 1687 and 1689 and Azov campaigns in 1695 and 1696. He was awarded generously by Peter the Great for his services. Although he did join the rebellion only in its third year, he led Bashkir rebels successfully and defeated Russian forces in a number of occasions. After the end of the rebellion realizing the futility of further resistance he sued for forgiveness and was pardoned. He also joined the famous mission of Tevkelev which brought Kazakhs of Small horde under Russian protection in 1731. See I. G. Akmanov, Bashkirskie Vosstania (Ufa: Kitap, 1993); I. G. Akmanov, "Bashkirskoe Vosstanie 1704-1711 gg." in Sbornik Nauchnykh Rabot Aspirantov Istoricheskogo Fakul'teta MGU (1963); R. N. Zinurov, Bashkirskie Vosstaniia i Indeiskie Voiny: Fenomen v Mirovoi Istorii (Ufa: Gilem, 2001); A. P. Chuloshnikov, "Feodal'nye Otnosheniia v Bashkirii i Bashkirskie Vosstaniia 17 i Pervoi Poloviny 18 vv." in Materialy po Istorii Bashkirskoi Istorii, part 1: Bashkirskie Vosstaniia $v$ 17 i Pervoi Polovine 18 vv. (Moskva\&Leningrad: Izdatel'stvo Akademii Nauk SSSR, 1936)
} 
thought that they could crush the resistance by brute force and by ruse. In early 1706, the Russian officials in Bashkiria encouraged Bashkirs to send a delegation to the Tsar to voice their grievances. Diumeii Ishkeev, the initiator of the rebellion from Kazan Doroga, and seven more less known leaders went to Moscow. They were duly arrested and sent back to Kazan, imprisoned and Ishkeev was executed. This ruse did nothing to relieve the Russians of the Bashkir rebellion.

During the second stage Bashkirs sent one of their leaders, Murat, possibly from Karakalpak background, to seek help from the Crimean Khan to open negotiations with the Ottoman sultan which ended in failure. On his way back to Bashkiria he joined the rebellion of the north Caucasian peoples and led a small regiment. He was finally captured and executed in northern Caucasia by the Russian authorities. ${ }^{98}$

There was even a brief attempt by the rebels to recognize the Karakalpak khan as the leader of Bashkirs. Possibly Bashkirs would have been unable to agree on any Bashkir noble around whom they could gather. In any case this attempt bore no fruits. The war ended in a stalemate. Neither the Russians, who were busy with Swedish wars and Pruth campaign against Ottomans, nor the Bashkirs, who lacked the means to get rid of the Russians were in a position to win an armed struggle.

This war was another example of the pattern in which policies of the center caused the deterioration of living conditions of the indigenous people and led to war. To avoid war, the center's demands should not exceed the capabilities of Bashkirs to realize those demands. Bashkirs never hesitated to resort to war in case the center violated the privileges Bashkirs jealously protected. In the thick of war with Sweden, however, Peter I was desperate for money

\footnotetext{
${ }^{98}$ Materialy po Istorii Bashkirskoi Istorii, part 1: Bashkirskie Vosstaniia v 17 i Pervoi Polovine $18 v v$. (Moskva\&Leningrad: Izdatel'stvo Akademii Nauk SSSR, 1936), 238-243
} 
and was in no condition to consider the balance of power in Bashkiria. To make matters worse the first decade of the 1700s was also a period of rebellions by Cossacks in the Don River basin under Bulavin and by the Streltsy in Astrakhan. Especially Bulavin's rebellion was the most prominent coordinated resistance to Peter's modernizing reforms and increasing demands of obligation from the population. ${ }^{99}$ The Bashkirs were not spared as well. During this tumultuous decade their obligations were increased several-fold and they suffered dearly under the heavy pressure of Tsarist officials sent to the region to collect exorbitant taxes. The fiscal demands of the government reached ridiculous levels and some seventy new types of taxes were imposed on Bashkirs.

Even though at that time Peter was determined to make Russia a great power and a modern country, Bashkiria was not in the list of his priorities. But that was not the case for taxation of Bashkirs. They were pushed hard and they were driven to the spot where Russia's new capital would rise and they were forced to join the labor forces that built St. Petersburg. In addition, Peter began the exploitation of Bashkiria's natural resources. The first large factories were constructed in 1701 .

Again in 1701 Peter the Great made an administrative arrangement in the status of Bashkiria within the Russian empire, according to which the Ufa administration was made subject to the control of the Kazan administrative unit. The duty to collect Iasak was transferred to Kazan, and all the inventories that designated the names of Iasak payers were delivered to Kazan voevoda. This arrangement violated the former practices where Bashkirs were directly under the authority of the Tsar. By being transferred to Kazan they were losing their access to the Tsar. There was a certain loss of status of Bashkirs and in fact this arrangement was

\footnotetext{
${ }^{99}$ Brian J. Boeck, Imperial Boundaries: Cossack Communities and Empire-Building in the Age of Peter the Great (New York : Cambridge University Press, 2009), 172.
} 
evidence of Peter the Great's determination to abandon past practices and elevate himself, the Russian emperor, now to a much higher status than the previous Russian rulers. This time the provincial inorodtsy would have no means to reach the emperor directly. Instead the emperor's servants (officials) would deal with the non-Russian subjects. ${ }^{100}$

This demotion in status also meant a greater financial burden for Bashkirs. As Aznabaev argues, the imperial government in order to increase its revenues to finance the Swedish war was determined to bring Bashkirs into a closer orbit of the central government and to achieve this it first attacked the client status of Bashkirs by making them subject to the military governor of Kazan. ${ }^{101}$ The elimination of client status of Bashkirs would result in the imposition of higher taxes than simple Iasak payments, which were losing their meaning by that time due to the extinction of the fur bearing animals in the region.

The leverage of revenues of Ufa government from Iasak was declining over the period of forty years from 1660 to 1700 . This decline was evidence that Iasak paying Bashkirs' importance was also declining for the Russian authorities. In order not to disturb regular delivery of Iasak payments the central government from an economic standpoint was not willing to incite Bashkir armed rebellion for the most part of the seventeenth century but as the revenues from Iasak declined there would be less and less incentives for the government not to antagonize Bashkirs as seen from the table below. ${ }^{102}$

\begin{tabular}{|c|c|c|}
\hline Source of Revenues & $1660 \mathrm{~s}$ & 1700 \\
\hline
\end{tabular}

\footnotetext{
${ }^{100}$ B. A. Aznabaev, Integratsiia Bashkirii v Administrativniiu Strukturu Rossiiskogo Gosudarstva (Vtoraia Polovina 16-Pervaia Treti 18 vv.) (RIO BashGU: Ufa, 2005), 149-150; Salavat Taimasov, “Aldar Kusiumovskoe Vosstanie i Politicheskoe Polozhenie Bashkortostana v Pervoi Treti 18 Veka”, Vatandash, 8, (2008).

${ }^{101}$ B. A. Aznabaev, Integratsiia Bashkirii v Administrativniiu Strukturu Rossiiskogo Gosudarstva (Vtoraia Polovina 16-Pervaia Treti 18 vv.) (RIO BashGU: Ufa, 2005), 152.

102 B. A. Aznabaev, Integratsiia Bashkirii v Administrativniiu Strukturu Rossiiskogo Gosudarstva (Vtoraia Polovina 16-Pervaia Treti 18 vv.) (RIO BashGU: Ufa, 2005), 127.
} 


\begin{tabular}{|c|c|c|c|c|}
\hline & Ruble & $\%$ & Ruble & $\%$ \\
\hline Customs & 818 & $9.50 \%$ & 1000 & $9.40 \%$ \\
\hline Taverns (Kabatskie) & 271 & $3.10 \%$ & 500 & $4.70 \%$ \\
\hline Horse Fees & 200 & $2.30 \%$ & 951 & $9.20 \%$ \\
\hline Quitrent & 200 & $2.30 \%$ & 500 & $4.70 \%$ \\
\hline Salt & 120 & $1.30 \%$ & 400 & $3.70 \%$ \\
\hline Peasants & 260 & $3.30 \%$ & 320 & $3.20 \%$ \\
\hline Shops and Trades & 30 & $0.30 \%$ & 70 & $0.60 \%$ \\
\hline Petitions & 34 & $0.30 \%$ & 100 & $0.90 \%$ \\
\hline Iasak & 6725 & $77.6 \%$ & 6725 & $63.60 \%$ \\
\hline Total & 8658 & $100 \%$ & 10566 & $100 \%$ \\
\hline
\end{tabular}

The wars between Russians and Bashkirs by 1711 ended in a stalemate. Neither party could continue to fight, so they reached a compromise. This was exactly what Richard White described as Middle Ground, where both sides, the intruder (Russians) and indigenous people (Bashkirs) were unable to gain by force. ${ }^{103}$ The first episode of the Russo-Bashkir relations fits into category of the delicate balance between the intruder and the natives. The government was too weak to impose its will on the natives and the Bashkirs were incapable of removing Russians. What Terry Martin describes for New Russia of the late 1700s perfectly fits to Bashkiria in the early 1700s: an outlying region where the economic, legal and social relations of the nation's heartland have not yet been reproduced. It was still sparsely populated and the center's presence was identified with a considerable military power rather than settler

\footnotetext{
${ }^{103}$ Richard White, The Middle Ground; Indians, Empires and Republics in the Great Lakes Region, 1650-1815, (New York: Cambridge University Press, 1991), 52.
} 
colonies. ${ }^{104}$ The Russian state yielded to the natives' demands to a great degree. So the first period of Russo-Bashkir relations is an evidence that empires were not entities relying exclusively on the brute force and wanton violence but rather they tended to be accommodating entities which desired to keep subject peoples satisfied with their political status to the degree socio-economic and political conditions allowed. The concessions by the Russian state to the rebellious Bashkirs were not signs of the weakness of the imperial system but an evidence of the imperial authorities' willingness to justify their rule in the borderlands by gaining the loyalties and accordingly services of the borderland peoples.

The Russian Empire unlike West European colonial empires was a contiguous one, largely because of the non-existent geographical boundaries, and as settlers' colonies sprang up the borderland areas were increasingly considered part of the motherland. Accordingly Russian authorities were not interested in exterminating native peoples of the borderlands (because they were subjects of the empire, not chained slave laborers.) but preserving them as valuable Iasak payers. The cooptation of the local elite into the service of the empire was a good indicator of the Russian authorities' determination to make the borderlands inseparable part of the empire. ${ }^{105}$ Bashkirs jealously defended their privileges and did not hesitate to pay a heavy price for this. On the other hand Russian central authority did not have a clear-cut plan about the region except the security of their borders. The region during this first period of Russian suzerainty presented itself as a genuine frontier area with diverse groups such as adventurers, fur trappers and land grabbers, who did not have means of livelihood in the European parts of Russia. They

\footnotetext{
${ }^{104}$ Terry Martin, “The Empire's New Frontiers: New Russia's Path from Frontier to Okraina, 1774-1920” Russian History, v. 19, No: 1-4 (1992), 181

${ }^{105}$ For greater conceptual details about the imperial authorities' resolve to integrate borderlands and native elites see Ronald G. Suny, "The Russian Empire" in After Empire; Multiethnic Societies and Nation Building; The Soviet Union and the Russian, Ottoman and Habsburg Empires ed. Karen Barkey \& Mark von Hagen, (Westview Press: Boulder, Colorado, 1997), 142-154.
} 
sought security and freedom of religion and thereby escaping to the points where the repressive Russian political regime did not reach firmly. So the region was genuinely a frontier area from Russian perspective.

Even though the last war of this period took place during the second half of Peter's reign, considering the results of this episode, this war was more typical of the Muscovite period than of Peter the Great's reign because it ended in the the misleading impression on the part of Bashkirs that they had emerged victorious in appearance and the central government stepped back which was good enough for Bashkirs at the moment. Once again the central government proved to be not strong enough to pacify this belligerent people for the same reasons as were witnessed during the earlier wars.

Russian rule in Bashkiria was not exclusively rule by brutality. On the contrary the central authorities at times deliberately punished excesses of the local administrators. Though brutalization was an inseparable part of Russian policy during the rebellions, these were not out of a sense of joy but necessity. The Russian government, long after the end of the 1704-1711 rebellion, publicly tried one of the Russian officials, a man called Sergeev, for excessive brutality and sentenced him to jail. In 1724 Bashkirs and those who lived in Bashkiria were exempted from poll tax as well. ${ }^{106}$ The Russian authorities as imperial officials had keen interest in the tranquility of the frontiers and deliberately avoided harsh policies which could lead to upheavals. Once they were sure that the region was completely tranquil they followed a discreet policy to give Bashkirs a greater role in the administration of their homeland. In this context for the first time loyal Bashkirs were given the task of collecting their own taxes in the late $1720 \mathrm{~s}$ when the administration of the region was entrusted to the imperial Senate. ${ }^{107}$ This policy

\footnotetext{
${ }^{106}$ I. G. Akmanov, Bashkirskie Vosstaniia (Ufa: Kitap, 1993), 220

${ }^{107}$ I. G. Akmanov, Bashkirskie Vosstaniia (Ufa: Kitap, 1993), 220:
} 
definitely led to stratification within the Bashkir society and those who were entrusted with the task of collecting taxes had greater benefits from the Russian government and would not want to risk their gains in another futile rebellion.

\section{Conclusion}

Bashkir rebellions of this period and the Russian policies in the aftermath of these rebellions indicated the Russian imperial authorities' flexibility and their preference for compromise over conflict. They were not jealous of their gains and were to a limited degree quite willing to share them with their former native opponents. They were quick to pardon actual leaders of the rebellions and by treating them with respect, the central government bought their loyalties. The empire in this context proved to be not an avenger but a benevolent benefactor. ${ }^{108}$ The natives on the other hand had to understand one basic priority rule of the imperial system: tranquility of the frontiers, which could produce a win-win deal in case of collaboration with the center. In case this rule was is neglected the natives would suffer direly at the hands of the imperial masters, as was the case during the greatest Russo-Bashkir conflict of the 1730 s.

\footnotetext{
${ }^{108}$ The Russian attitude towards Bashkir rebels and the Don Cossacks is not radically different. See Brian J. Boeck, Imperial Boundaries, Cossack Communities and Empire-Building in the Age of Peter the Great,(Cambridge: Cambridge University Press, 2009), 2-3.
} 


\section{Chapter 3 \\ Bashkirs under Russians 1711- 1756}

The period between 1711 and 1755 witnessed an expansion of Russian control in Bashkiria. The Petrine reforms of the early 1700 s radically changed the relations between the center and the periphery. The Imperial regime was now a more imposing one determined to increase the center's leverage in the borderlands. A considerably larger colonial bureaucracy busied itself with the classification of the people and their peculiarities. It investigated the potential riches of the provinces and conducted ethnographic studies of the native populations. Peter the Great's reforms irrevocably changed the course of history in Bashkiria. ${ }^{1}$ This trend became prevalent in most of the colonial empires of the west in the nineteenth century. In those empires, professional civil servants conducted ethnographic research and wrote reports on the local traditions. ${ }^{2}$ The more the center imposed its will on the natives, the more the natives willy-nilly were victimized and the more they became transformed under the weight of an increasingly alien culture.

Especially during this stage the empire started to play an increasingly influential role in the lives of the natives as more and more imperial officials flowed into the region to impose imperial policies with a Europeanized outlook,. The frontier for the Bashkirs during this period slowly closed and in the most dramatic way in the period that lasted from 1711 to 1755 when the last genuine Bashkir rebellion took place. The Russia of

\footnotetext{
${ }^{1}$ A similar shift took place in British India in the 1860s after the Sepoi Rebellion was suppressed in 1857. See; Ann Laura Stoler and Frederick Cooper, "Between Metropole and Colony, Rethinking a Research Agenda" in Tensions of Empire, Colonial Cultures in a Bourgeois World, ed. Frederick Cooper and Ann Laura Stoler, (London: University of California Press, 1997), 6.

${ }^{2}$ D. Chidester, Savage Systems: Colonialism and Comparative Religion in Southern Africa, (Charlottesville: University of Virginia Press, 1996), 9
} 
Peter the Great's successors was radically different from Muscovite Russia in its relation to Bashkirs. For one thing the government became more assertive in the affairs of the region and more self-confident in its relations with the Bashkirs. During the bloodiest Russo-Bashkir war the governmental forces were confident enough to reject any compromise and conducted a nearly genocidal war against the Bashkirs. ${ }^{3}$ The Bashkirs emerged from the war in the most abject conditions. They never fully recovered demographically from this near annihilation despite two more attempts in a much debilitated and diminished form to resist governmental incursions. ${ }^{4}$

Yet the Bashkirs survived and it became clear that the Bashkirs would remain in their region and would never resort to mass exodus as became the case for Kalmyks in the 1770s or Crimean Tatars in the 1780 and the 1790s. Despite their near annihilation this episode ended up with an ironic success for Bashkirs, because it became certain that Bashkiria, Orenburg gubernia after 1744, was confirmed as the lands of the Bashkirs. They did not become extinct as did many similar tribal groups to their east. They were neither exiled in a massive scale, ${ }^{5}$ despite proposals to this end, nor were they Christianized to any significant degree. The catastrophe of their bloody wars against the Russian government was so great that the authorities never dared to christianize Bashkirs as they did in the Middle Volga region. The government later made one more attempt to extend their christianization policy to the Bashkir groups, but Bashkirs again resisted by

\footnotetext{
${ }^{3}$ The Russian government did not mean to exterminate Bashkirs and did not follow a premeditated policy of annihilation. However, their methods to quell the Bashkir rebellion were so devastating that a significant part of the Bashkir population was killed.

${ }^{4}$ I. G. Akmanov, Bashkiriia v Sostave Rossiiskogo Gosudarstva 17-Pervoi Polovine 18 Veka (Sverdlovsk: Izdatel'stvo Ural'skogo Universiteta, 1991), 151

${ }^{5}$ The number of Bashkirs who were exiled, killed, executed or died of hunger and exposure was about 60 thousand nearly $1 / 5$ of the all Bashkirs. See; R. G. Kuzeev, Istoricheskaia Etnografiia Bashkirskogo Naroda (Ufa: Bashkirskoe Knizhnoe Izdatel'stvo, 1978), 154; But the population of Bashkirs in the 1600s and $1700 \mathrm{~s}$ is a matter of great debate.
} 
force of arms. Bashkirs' and to a lesser degree other non-Russian groups' resistance made the Russian authorities abandon their policy of christianization of the non-Russian peoples of Russia, including those who had escaped from the middle Volga in the 1730s and 1740s during the peak moment of christianization efforts. So other Muslim peoples of the Volga region benefitted from Bashkir resistance.

The Bashkir wars of this period resulted in a greater determination for Bashkirs to preserve their distinct identity. Their attachment to Islam also increased greatly and the last genuine Bashkir war derived from this factor. I will also argue that even though the borders were closing on Bashkirs, cultural factors began to play a more divisive role between Bashkirs and Russians. The Russian authorities never fully solved this problem.

\section{Imperial Russia’s Bashkir frontier, 1700-1734}

The Russian government's concessions to Bashkirs in 1711 were the last of its kind and would not be repeated. The Bashkir threat continued against those Russians who settled or served in the region which made the region insecure, a genuine feature of frontier society. The years between 1684 and 1704 were the formative period of transition from an extractive empire to an exploitative one. I use the term exploitative in the sense that the central authority attempts to draw as much income from a region as possible in the context of its human and natural resources. Peter the Great's attempts to impose as many different taxes as possible on the Bashkir people reflected this shift from extractive period to exploitative period. The imperial administration under Peter the Great was transformed from a distant entity to the comprehensive and inclusive entity. Peter the Great was intent on creating an empire, not specifically for the Great Russians 
(Russkii) but for other nationalities as well (Rossiiskii). ${ }^{6}$ Nationalities would also bear the brunt of running the empire which required their closer attachment to the center. During and after Peter's reign the imperial authorities tried to make frontier regions an integral part of the empire. The former Iasak payers would have to join to this effort by giving up a certain amount of their land to the new imperial projects. If they did not comply voluntarily, they would be made to do so.

During the 1704-1711 Russo-Bashkir wars Russians were not strong enough to impose their will, but time was on their side. There had emerged a certain leadership in this once acephalous society from among the cattle- and horse-rich Bashkir nobility and Muslim religious opinion leaders. ${ }^{7}$ Not surprisingly the two great Russo-Bashkir wars of this period (1735-1740 and 1755) were led by either rich Bashkir nobles or a Muslim scholar called Batyrsha who was supposedly a Tatar or Mishar scholar.

The period from 1711 to 1755 witnessed great efforts by the Russian authorities to close down the frontier region and by the Bashkirs to prevent them. By the end of the period it became clear that the frontier was fully closed down. Bashkirs found themselves encircled within the Russian Empire and the porous nature of the Bashkir frontier ceased to exist. This period was also extremely rich in cross-cultural interactions which took place mainly between Bashkirs and Tatars. Between Bashkirs and Russians mainly economic relations developed.

The Bashkir frontier closed in this period mainly because of the increasing control of the region by the authorities. In particular, the Russian government built a new

\footnotetext{
${ }^{6}$ Marc Raeff, Political Ideas and Institutions in Imperial Russia, (Boulder: Westview Press, 1997), 126. ${ }^{7}$ Opinion leader is a man of learning in the Islamic societies. They are generally from the scholarly classes and they mostly perform the task of speaking the mood of the society to the authorities. If there emerges a dire necessity they can even lead the peoples.
} 
defensive line which started in the early 1730 s, the famous Orenburg defensive line, which effectively imprisoned Bashkirs within the Russian Empire. One other reason for the frontier closure was that Bashkirs were increasingly reduced to a minority in their own region by the mid-1750s as large numbers of Russians and non-Russian minorities migrated from the European Russia and the Middle Volga, with governmental planning and encouragement. Such a migration and resettlement policy became possible only after the Bashkirs were believed to pose no more threat to the authorities and settlers.

The Russian administrative system in the Volga-Ural region underwent a radical change. First of all Kazan Gubernia was created and a number of towns were attached to the guberniia, including $\mathrm{Ufa}^{8}$ Then the system of voevodas was terminated in 1709 and as part of Peter's reforms to strengthen central government authority, Ufa province was created in 1712. ${ }^{9}$ This arrangement was designed to put an end to the old pattern of local government in which voevodas exercised a nearly absolute authority in their seats, which caused enormous problems for the central government due to their unchecked powers. The arbitrariness of the voevodas had contributed to all the Bashkir rebellions of the $17^{\text {th }}$ century, and the Bashkirs had repeatedly demanded their removal. The issue was the bad

\footnotetext{
${ }^{8}$ Some other major towns of the region that had been included in the Kazan Gubernia were Iaik, Terek, Astrakhan, Nizhnii Novgorod, Samara, Simbirsk, Tsaritsyn and etc. F. Kh. Gumerov, compiler, Zakony Rossiiskoi Imperii o Bashkirakh, Mishariakh, Teptiariakh i Bobyliakh (Ufa: Kitap, 1999), 20.

${ }^{9}$ Imperial Russian historians argue that Ufa province was created in 1708 in connection with the creation of Kazan Gubernii. See, V. M. Cheremshanskii, Opisanie Oreburgskoi Gubernii v KhoziainstvennoStatisticheskom, Etnograficheskom i Promyshlennom Otnosheniiakh, (Ufa: 1859), 5; V. A. Novikov, Sbornik Materialov dlia Istorii Ufimskogo Dvorianstvo, (Ufa, 1879), 14; V. N. Vitevskii, I. I. Nepliuev i Orenburgskii Krai v Prezhnem ego Sostave do 1758 g. Part 3 (Kazan: 1891), 388; For a more detailed account of the creation of the Ufa province see; I. Bikkulov, "Uchrezhdenie Ufimskoi Provintsii v Nachale 18 Veka" Vatandash, 10, (2006). The author fails to give an account of the background reasons of this administrative reorganization. But it is a valuable condensed essay which gives judicial background of the imperial adjustments in the administration of the region.
} 
local administration and the government responded with reforms after crushing the rebellions.

Between 1728 and 1731 Ufa province was under direct administration of the Imperial Senate. There seem to have been two reasons for such an arrangement. Zufar Enikeev argued that the Senate directly administered Bashkiria because it recognized the Bashkirs' special status for their voluntary incorporation into Russian Empire. ${ }^{10}$ This argument seems problematic because the Russian governments repeatedly violated Bashkirs' votchina rights during the seventeenth century. The other possible option is that the Bashkirs were the only people west of the Urals who still posed enormous troubles to the Russian government. The authorities, in order to deal with the Bashkir problems, might have decided to take over the direct administration of the region. The earlier Russian officials in the region, especially voevodas, had dismally failed to establish an effective Russian administration in the region. The clear evidence for this failure of the voevodas is that between 1590 and 1708, 55 voevodas served in the region and 51 of them were dismissed. ${ }^{11}$

\section{New Imperial Projects in Bashkiria}

New imperial thinking was the harbinger of future governmental attempts to tie the peripheral areas more strictly to the center, which would enable the agents of the government to make better use of the economic potential of the regions. The first step to bring Bashkiria within the economic sphere of the empire was to eliminate the factors that prevented exploitation of the region's natural riches, where rich deposits of iron and copper had recently been discovered. Peter the Great and his successors were determined

${ }^{10}$ Zufar Enikeev, Pravavoi Status Bashkortostana v Sostav Rossii (Ufa: Gilem, 2002), 59.

${ }^{11}$ Zufar Enikeev, Pravavoi Status Bashkortostana v Sostav Rossii (Ufa: Gilem, 2002), 57. 
to put an end to "the Bashkir problem"12 and for this reason they adopted a policy of narrowing the frontier. In this context, the construction of the New Trans-Zama defensive line was started in 1731 and finished by 1736. The local peoples were forced to work on its construction and were also levied with an extraordinary tax called “Zasechnaia Money.",13

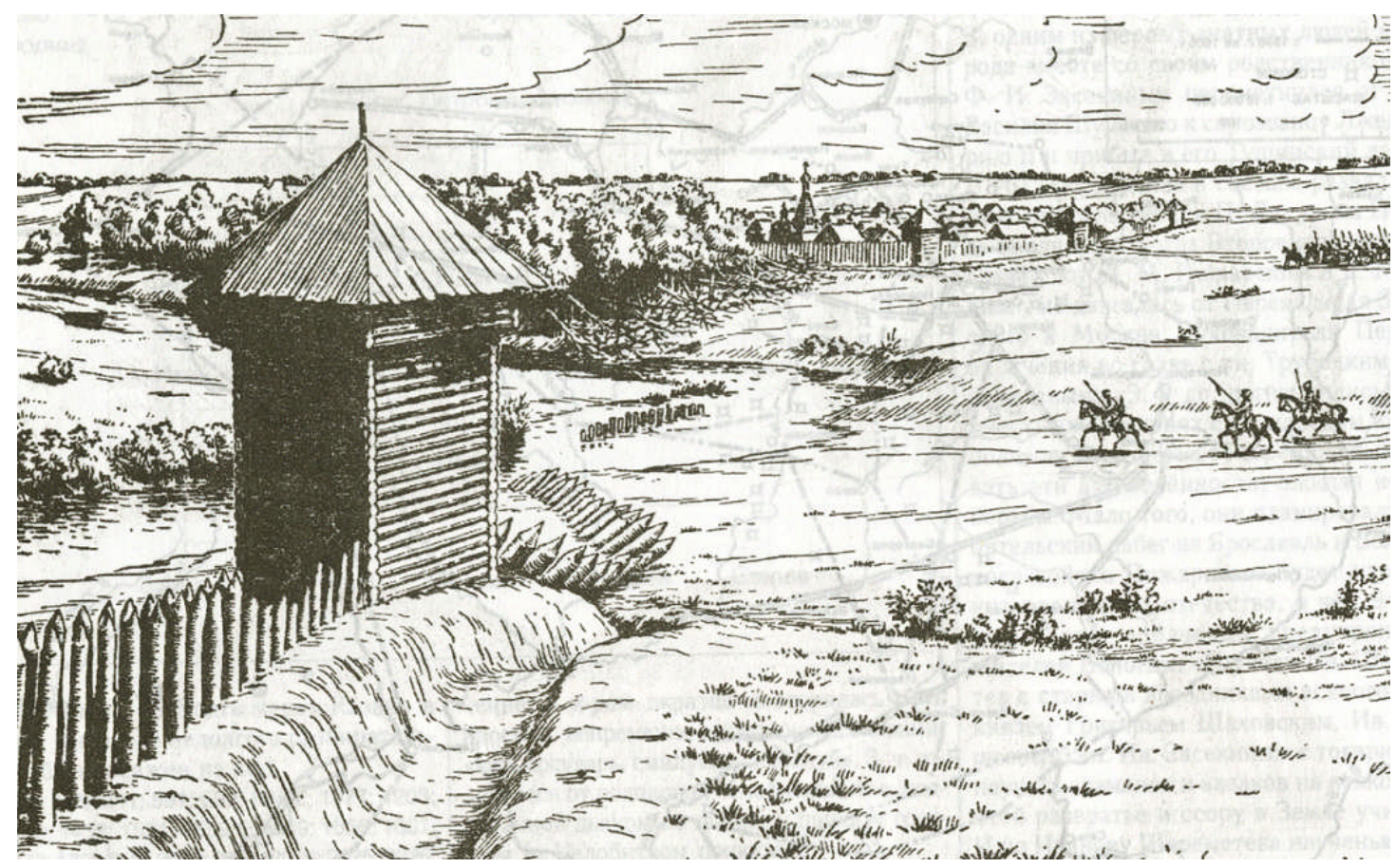

The image above is an example of the Russian wooden defensive line called Zasechnaia Cherta. The government constructed such fortifications widely in the southern and southeastern steppe in the $16^{\text {th }}$ and $17^{\text {th }}$ centuries. $^{14}$

\footnotetext{
${ }^{12}$ Boris Mironov has earlier phrased "Bashkir question" and argued that it was solved by the end of the eighteenth century. The prohibition of the extension of serfdom was a factor in the resolution of this question. Boris M. Mironov, The Social History of Imperial Russia, 1700-1917, v.1, (Boulder; Colorado: Westview Press, 2000), 15

${ }^{13}$ V. A. Kuznetsov, "Novaia Zakamskaia Liniia i Obrazovanie Landmilitsii" Izvestiia Samarskogo Nauchnogo Tsentra Rossiiskoi Akademii Nauk, 11, (2009), 35.

${ }^{14}$ V. V. Boguslavskii, Slavianskaia Entsiklopediia, v.1, (Moskva: Olma-Press, 2004), 472.
} 
Like the earlier defensive lines, the government constructed the Trans-Zama line to protect against the nomadic groups, to defend villages and Russian settlements, and to prevent subject peoples of Russia from forming alliances with the nomadic groups beyond Russian borders against the government. This line originated with the defensive system of the old Trans-Kama fortifications constructed in the 1650s. The line extended from the Samara River to the Kama River and effectively cut Bashkir lands into two. Interestingly, Bashkirs did not rebel against the construction of this line. They rather waited for several more years to react Russian encirclement policy when the construction of the Orenburg defensive line was first started in 1734.

This Russian project to construct a major town in southern Bashkiria was not coincidental and not confined to Bashkir relations. In fact it was the result of long term Russian projects. After the Great Northern War was successfully concluded in 1721, Russian foreign policy focused more and more on Asia. ${ }^{15}$ In this context Peter the Great fought against Persia from 1722 to 1725 . Despite being victorious, military and logistical problems forced subsequent Russian rulers to abandon Peter's gains in Iran in the early 1730s. They then turned southeast towards central Asia and in the late 1720 s and early 1730s they tried to bring Kazakhs into the orbit of Russian empire by granting them client status. In this context Bashkiria played a key role as a springboard towards central Asia.

\footnotetext{
${ }^{15}$ In fact during the war against Sweden Peter the Great sent some expeditionary forces deep into Central Asia and Kazakh steppes to exploit the economic potential of these regions. The infamous expedition under prince Cherkassky sent against Khiva ended in disaster in 1716. Only a few soldiers out of 5000 managed to return. The other expedition under Bukhgoltz was designed to survey the northern Kazakh lands. This expedition brought only modest results. See respectively V. Illeritskii, "Ekspeditsii Kniazia Cherkasskogo v Khivu" Istoricheskii Zhurnal, (1940); Z. Kasymbaev, "Ekspeditsiia Bukhgoltsa i Sozdanie Priirtyshskikh Krepostei v Nachale 18 Veka” Istoricheskie Nauki, 1. (1974)
} 
Even though in the circles of the central government of the Russian empire Bashkirs were portrayed as mere savages, Bashkirs could perceive the results of the Russian policies in the region and they apprehensively anticipated the future consequences of the policy changes in the region. Their most radical problems were their inability to unify themselves and to win support from the other Turkic groups beyond Russia. By the 1730s the Russians had already solved many of their military problems and they were better prepared to deal with the Bashkir resistance. This does not mean that Russians had already overcome all their problems. Logistical support was still a great problem that Russian troops in the region had to deal with. In one case when Orenburg was first constructed at the mouth of the Or river in 1734, troops stationed there had very quickly consumed their provisions and in order not to starve to death at the middle of the winter, they abandoned the fortress in search of food on their way to Ufa. Of 800 troops $2 / 3$ of them died of starvation and frost.

The project to develop a new defensive system originated with Ivan K. Kirilov (1689-1737). Kirilov was a leading Russian official who was a product of Peter the Great's westernization policy. He was a leading mathematician and geographer. He led researches about astronomy, cartography and topography. In 1727 he wrote the first systematic economic and geographic description of Russia. He was also a member of the Senate as of 1712 and its general secretary after 1727.

Kirilov was one of the first protagonists of the ideas of colonizing Bashkiria, conquest of Kazakh lands, expansion of Russian influence in Central Asia and 
developing trade relations with India. ${ }^{16} \mathrm{He}$ dreamed of developing trade relations with Central Asia, for which they needed to establish a secure base in the Kazakh lands by bringing Kazakhs into the orbit of Russia in the form of patron-client relations. He came up with the idea and persuaded other top officials to implement his project. Although the idea of building a town at the mouth of the river Or belonged to Kutlu Mukhammed Tevkelev $^{17}$, Kirilov transformed that idea into a comprehensive imperial project with enormous ambitions, including potentially reaching India. ${ }^{18}$

The onslaught of Dzhungars on Kazakh lands and Kazakh Hordes (Zhuzh) in the 1720s was an opportunity for the Russians in this context because outside elements like the Dzhungar invasion of Kazakh lands served as an excuse for Russian expansion into Fthe region. Desperate Kazakhs fleeing before Dzhungars requested Russian help and formal protection. Such events facilitated Russian encroachment in the region but this could be achieved only after securing Russia's Bashkir region. The privy councilor A. P. Bestiuzhev-Riumin supported Kirilov's proposal and in May 1734, Empress Anna sanctioned it. Kirilov and Tevkelev proceeded to carry out the project. ${ }^{19}$ Even though he was in the first place a polymath scholar, he proved that he could be a ruthless frontier

\footnotetext{
${ }^{16}$ L. E Iofa, Sovremenniki Lomonosova: I. K. Kirilov and V. N. Tatishchev, Geografy Pervoi Poloviny $18 v$. (Moskva: 1949), 3-35; M. G. Novlianskaia, I. K. Kirilov i ego Atlas Vserossiiskoi Imperii, (Moskva\&Leningrad: Izdatel'stvo Akademii Nauk SSSR, 1958)

${ }^{17}$ Kutlu Mukhammed Tevkelev (1674-1766) was a Tatar noble who entered to the service of the Russian state and served as Tsarina's agent to Kazakhs of the Lesser Horde. Tevkelev family was one of the noblest Tatar families who served Russians at different times. Kutlu Mukhammed converted to Orthodoxy and became a Russian general. He played a very active role in the development of Russo-Kazakh relations and the pacification of Bashkir lands as military leader and mentor. Later on he became a very close associate of Nepliuev, the distinguished and effective governor of Orenburg. See D. Iu. Arapov, "Pervyi Russkii General Musulmanin Kutlu-Mukhammed Tevkelev" Sbornik Russkogo Istoricheskogo Obshchestva, 5, (2002)

${ }^{18}$ Alton S. Donnelly, The Orenburg Expedition: Russian Colonial Policies on the Southeastern Frontier, 1734-1740 (University of California, 1960 Ph.D. ), 103

${ }^{19}$ Alton S. Donnelly, The Orenburg Expedition: Russian Colonial Policies on the Southeastern Frontier, 1734-1740 (University of California, 1960 Ph.D. ), 107
} 
administrator. His main plan, while departing for the frontier, was to suppress Bashkir resistance and secure the region for Russian expansion at all costs and he was ready to do whatever was needed for this objective.

The Orenburg expedition was a good example of Imperial thinking. It was an ambitious project with multiple goals: integrating one region into the imperial system; creating room for the excess population and distributing land to them; thrusting to the heart of the Kazakh lands as the target of the next imperial conquests; strengthening the trade links with Central Asia; and if possible, reaching India which was still not dominated by any European power. Kirilov, acting vigorously, quickly formed his expeditionary force and gathered the leading scholars of Russia at the time. The expedition was composed of about two hundred specialists and a military detachment of about 2500. Among the participants were professionals, respected scholars including astronomer and mathematician D. Elton, botanist I. G. Geyntselman, surveyors P. Chichagov A. Kleshnin, M. Pestrikov, painter D. Kestl, specialist geologists and students of the Slavic-Greek-Latin Academy. P. I. Rychkov, as an accountant, took part in the expedition. Realizing the importance of the public and scientific value of the expedition, ${ }^{20}$ Mikhail Lomonosov also wanted to join the expedition but this never materialized. ${ }^{21}$ Such a sophisticated group of experts had many more goals than simply

\footnotetext{
${ }^{20}$ This expedition was initially called Izvestnyi(Certain) Expedition. It was later recalled Orenburg Expedition. L. E Iofa, Sovremenniki Lomonosova: I. K. Kirilov and V. N. Tatishchev, Geografy Pervoi Poloviny 18 v. (Moskva: 1949), 25.

${ }^{21}$ Under Peter the Great, there were a few attempts to send expeditions to Central Asia by bypassing Bashkiria. One, the expedition of prince Cherkassky to Khiva, ended in disaster and the other one led by Bukhgolts produced dubious results, if not disaster. The expedition of Bukhgolts mainly focused on Northern Kazakhstan and Irtysh fortified line's first fortresses were established- Omsk (1717), Semipalatinsk (1718) and Ust-Kamenegorsk (1720). See, V. Illeritskii, "Ekspeditsii Kniazia Cherkasskogo v Khivu” Istoricheskii Zhurnal, (1940); Z. Kasymbaev, "Ekspeditsiia Bukhgoltsa i Sozdanie Priirtyshskikh
} 
constructing a defensive line. The plans for exploration and investigation mean that Russians had more in mind than mere exploitation. The political aim was to integrate the region more completely into Russia by breaking Bashkirs' traditional socio-economic system and to create necessary conditions for the opening of the region to the future and more orderly settlement to the Russians.

Just as Western Europeans opened Americas and Africa to the European Christian civilization, Peter the Great's and his successors' policies of sending missions and expeditions were in the same fashion as Bartolomeu Dias and his contemporaries. The lands to the east of European Russia were due to be explored and opened to the western civilization. However, the Russian imperial authorities unlike their counterparts in Western Europe did not see the subject peoples as objects of mere exploitation and enslavement. They were lesser partners of Russians who were expected to serve their Russian tsars. On the contrary while Russian peasants in European Russia were enserfed and closely tied to the land they tilled, Bashkirs were not even included within the orbit of excessive taxation let alone enserfment. It must be underlined that the Russian authorities did not tolerate rebellions and opposition to the central government's policies. During such cases, the authorities used a heavy hand to suppress dissent.

The Bashkir groups objected to the project on the grounds that construction of fortresses violated the privileges granted to them by the Russian Tsar Ivan IV. On the other hand Kirilov was a haughty administrator who refused to inform Bashkirs about the real goals of the project. Despite Russian attempts to conceal the direction and goals of the expedition, they became known to the Bashkirs even before the expedition arrived at (Stanford, California: Hoover Institution Press, 1995), 30 
the scene. Two Bashkirs envoys visited Kirilov and attempted to persuade him to abandon the expedition and threatened him with another Bashkir rebellion if the construction at the mouth of the Or' river was started. Not willing to delay the outbreak of the armed hostilities, Kirilov brutally tortured the envoys which resulted in the death of one of them. The greatest Bashkir-Russian war started in response to the arbitrariness and brutality of Kirilov on July $15,1735 .^{22}$ Such domineering attitudes on the part of the Russian officials served only to exacerbate the situation not only for the Bashkirs but also for the Russians including Kirilov himself. ${ }^{23}$

His arrogant attitude was not exceptional because by the 1730s Russian officials had already adopted a western orientation thanks to Peter the Great's westernization efforts. As a result the Russian mindset had radically turned against the indigenous peoples of the empire. Russian leaders and intellectuals no longer viewed them as the descendants of Genghis Khan and no longer some sort of equals with the Russians. They were now eastern savages who had to be tamed and civilized. Russian officials had realized that they were the representatives of one of the greatest empires of the time and their views of the eastern peoples were tinctured with a deep condescension. When Mukhammed Tevkelev met with resistance during his diplomatic mission to the Kazakhst, he upbraided them in statements that reflect the new Russian thinking: "The Russian empire is in high repute among many states in the world, and it is not befitting

\footnotetext{
${ }^{22}$ I. G. Akmanov, ed., Istoriia Bashkortostana s Drevneishikh Vremen do Nashikh Dnei v Dvukh Tomakh v. 1, (Ufa: Kitap, 2007), 173.; A. Z. Asfandiiarov, "Dobrovolnoe Vkhozhdenie Bashkir v Sostav Russkogo Gosudarstvo", This essay is available in http://www.bashru-450.narod.ru/stati_2.html accessed on 18 November 2010: A. Z. Aznabaev claims that the rebellion started in June 1735. B. A. Aznabaev, Integratsiia Bashkirii v Administrativnuiu Strukturu Rossiiskogo Gosudarstva (Vtoraia Polovina 16-Pervaia Treti 18 vv.) (Ufa: RIO BashGU, 2005), 184

${ }^{23}$ Kirilov died at the height of the Bashkir rebellion due to the deprivations caused by a severe illness while campaigning against Bashkirs. He died of tuberculosis in Samara, April 1737. M. G. Novlianskaia, Ivan Ivanovich Kirilov, Geograf 18 Veka (Leningrad: Nauka, Leningradskoe otdelenie, 1964), 118.
} 
such an illustrious monarch to have a peace treaty with you, steppe beasts, ..... and signing a peace treaty with the Kazakhs would only defame the Russian empire." ${ }^{24}$ An ever confident Russian officialdom would no longer tolerate an equal footing with the 'savage' peoples of the east, and there would be no more diplomatic missions by these peoples to the Russian capital to have an audience with the Russian ruler as was the case in the past. The Russian administrators in the frontier areas would handle the relations with the local people from then on. As a result Russian treatment of the indigenous people in the frontier areas turned out to be more and more brutal, fed mainly by cultural and civilization-based biases. ${ }^{25}$

These biases led the Russian officials to a new approach about the Bashkir opposition to Russian expansion. Bashkirs were seen now as subhuman in the most radical way and the Bashkir problem could be solved through elimination of all Bashkirs by more violent (slaughter) or less violent (deportation) means. The first recorded plans about this issue appeared in 1725 in a project prepared by a Russian official in Bashkiria called Iukhnev who proposed to diminish the Bashkir population by deporting them to the central regions of European Russian and settling Russians in their place in Bashkiria. He stated that to solve the Bashkir problem and to preserve the safety of the region from the Bashkirs, without resorting to bloodshed, Russia should deport them to the interior of

\footnotetext{
${ }^{24}$ Translation belongs to Michael Khodarkovsky. Michael Khodarkovsky, Russia's Steppe Frontier; The Making of a Colonial Empire 1500-1800 (Bloomington \& Indianapolis: Indiana University Press, 2002), 153. However the original document is also available in F. N. Kireev, et.al., Kazakhsko-Russkie Otnosheniia v 16-18vv., (Alma-Ata: Izdatel'stvo Akademii Nauk Kazakhskoi SSR, 1961), 54.

${ }^{25}$ Even though Orthodoxy now became secondary motive for the discrimination of the indigenous people and it was the age of enlightenment and increasingly more and more Russian officials were mesmerized by the western ideas of secularism. Religion in the peripheral areas of Russia continued to play a prominent role in the upward socio-economic mobility for the indigenous people. The best example to this old fashioned attitude is the conversion of Tatar noble Kutlu Mukhamed Tevkelev and after conversion his elevation to high positions.
} 
Russia in small groups and then convert them to Christianity. So Bashkiria would be free from Bashkirs and ready for Russian colonization. ${ }^{26}$

Another Russian official from the surrounding area, A. P. Volynski, the governor of Kazan, ${ }^{27}$ rejected the proposal of deporting Bashkirs because it seemed impractical to deport a whole people and repopulate Bashkir lands with the Russian peasants. Instead he proposed to solve the problem right in Bashkiria by introducing new methods to minimize the rebellious potential of Bashkirs. Volynski argued that the Bashkirs must be sent to shed the blood of Kazakhs and Karakalpaks and of course these Bashkirs would also die, and there would be fewer able-bodied Bashkirs in the region. Also new legislation had to be enacted to prohibit Bashkirs from owning firearms with death penalty, the practice of keeping Bashkirs amanats had to continue, and the military strength of the government in the region had to be increased by strengthening the garrisons of the towns. New taxes had to be imposed to destroy Bashkirs economically. ${ }^{28}$ In Volynskii’s view Bashkirs were Mukhamedans (Moslems) who would never be loyal to the government. B. A. Aznabaev maintains that Senate did not take Volynskii's plans seriously because they were impractical. In 1709 when government deported some

\footnotetext{
${ }^{26}$ Materialy po Istorii Bashkirskoi ASSR, v. 3, (Moskva \& Leningrad: Izdatel'stvo Akademii Nauk, 1949), 487.

${ }^{27}$ Artemii P. Volynskii (1689-1740) was also one of the disciples of Peter the Great. He held several major posts under Peter the Great. He encouraged Peter the Great to start Persian war with the expectation that eastern routes of international trade would be captured. He promoted trade with the East and had projects of expanding Russia's economic and industrial potential. He served as the governor of Kazan from 1725 to 1730 and then played an active role in the post-Petrine politics. He fell victim to Birovshchina and was executed in 1740. See; D. A. Korsakov, Iz Zhizni Russkikh Deiatelei 18 v. (Kazan:1891); I. Shishkin, “A. P. Volynskii” Otechestvennye Zapiski, 128 (1860); Marc Raeff, Imperial Russia, 1682-1825: The Coming of Age of Modern Russia, (New York: Knopf, 1971), 17

${ }^{28}$ Materialy po Istorii Bashkirskoi Istorii, part 1, Bashkirskie Vosstaniia v 17 i Pervoi Polovine $18 v v$. (Moskva\&Leningrad: Izdatel'stvo Akademii Nauk SSSR, 1936), 302
} 
Bashkirs to Kazan Uezd, 9000 troops from the regular army, 10000 Cossack units and Kalmyk support were needed. ${ }^{29}$

\section{Bashkir Moves against the New Imperial Projects}

Aznabaev believes that Kirilov and his staff were caught by surprise when the war started in full scale in the summer of 1735 . This seems incredible because during the winter and spring of 1735, all-Bashkir lighins were held in several places throughout Bashkiria and Bashkir leaders extensively discussed what to do in the face of another Russian attempt to violate the land charter granted some 180 years earlier. In one of these lighins, it was decided that rebels would first burn down a Bashkir village, Buraevo, and then they would destroy the Mishars, Chuvash, Votiaks and Cheremis and finally attack the Russians. They also decided to gather under the leadership of Akai Kusiumov with ten thousand fighters. ${ }^{30}$ The rebels were determined to fight not only Russians but also all the other minority groups who supported Kirilov's expedition. The village Buraevo is located in the Osinsk doroga and was first founded in the early years of the seventeenth century and from the very beginning it was a farming community. ${ }^{31}$ So the residents of this village who settled down long ago did not care about whether a defensive line was constructed or not because they were not nomads. So the war, at least from this perspective, seemed a war between nomads and farmers.

\footnotetext{
${ }^{29}$ B. A. Aznabaev, Integratsiia Bashkirii v Administrativnuiu Strukturu Rossiiskogo Gosudarstva (Vtoraia Polovina 16-Pervaia Treti 18 vv.), (Ufa: RIO BashGU, 2005), 183.

${ }^{30}$ I. G. Akmanov, "Organizatsiia Orenburgskoi Ekspeditsii i Nachalo Vosstaniia 1735-1740 godov" in Ocherki Istorii Dorevoliutsionnoi Rossii, v. 2, ed. R. V. Filippov (Ufa: Bashkirskii Gos. Universitet, 1975), 124

${ }^{31}$ A. Z. Asfandiiarov, G. A. Gafarov, "Buraevo (Borai)" in Bashkirskaia Entsiklopediia, Vol. 1 ed. I. G. Akmanov and Aznagul Uruskulov (Ufa: Nauchnoe Izdatel'stvo, 2005), 566.
} 
These Iighins were one indicator that a Bashkir leadership was in the making as more and more Bashkirs who lived quite distant from each other were coming together, discussing matters relating to their survival and deciding what to do under whose leadership. The emergence of a leadership meant greater chances for the Bashkirs to produce a national identity. Unfortunately for Bashkir society the radical divisions had also come to the surface as the rebellious leadership decided to cut down collaborators, "loyal Bashkirs." For the rest of the war the casualties on both sides would escalate as hostilities deepened.

What Bashkirs historians have failed to explain so far was the reasons for these radical divisions within the Bashkir society. They have failed to analyze what factors made Bashkirs loyal and disloyal and what factors made them cut each others' throats so mercilessly. This could be explained by the brutality of frontier life since violence was always emphasized as a basic fact of frontier life due to the lack of a strong state authority. But it seems that the real reasons for these hostilities within the same ethnic groups are deeper. It must have been related to the differentiating level of the development of various Bashkir groups. Many of the loyal Bashkirs were from the western parts of Bashkiria where governmental control was stricter and colonization of the Bashkir lands was more intense and sedentarization level of Bashkirs was higher than those of the Bashkirs to the east and south of the region.

There was another dimension of this uneven level of economic development. In the past the Bashkir groups had generally received non-Bashkir peoples' support. But as was claimed by Chuloshnikov there was no large support by the other nationalities for this war. On the contrary the Mishars opposed the Bashkirs and closely cooperated with 
the punitive forces. They were accompanied by two newly emerging socio-economic groups in Bashkiria by this time, Teptiars and Bobyls, who had been working under Bashkirs either as tenants or tax payers. So unavoidably there were tensions among these groups. ${ }^{32}$ Bashkirs, thanks to the migration to their region, had turned out to be the renters of their lands to new groups of people, including Tatar, Chuvash, Cheremis, and Votiaks, who came to Bashkiria in the seventeenth and early eighteenth centuries. Kirilov and Rumiantsev in their report to the state senate in December 1735 stated that these groups were occasionally forced by the rebel Bashkirs to take part in their war but they proved to be highly unwilling ${ }^{33}$ since the result of the war would change nothing for these people. So they proved to be highly unreliable for the Bashkirs and an asset for the Russians.

As for the Russian side during the critical months spanning from winter to early summer of 1735, Kirilov had many Bashkir tarkhans serving under him and consequently must have known about rebellious attitudes among the Bashkirs. A loyal Tatar sotnik (lieutenant) Nadyr Mullah who had joined one of these lighins reported about the forthcoming turmoil. He reported that those who attended the meeting almost universally decided not to move unless the Russians moved; not to let Russians construct the town and cut them down. ${ }^{34}$ Alton Donnelly states that Kirilov had been warned by Tatishchev, the governor of Ekaterinburg, about the real goals of these lighins but he ignored these

\footnotetext{
${ }^{32}$ A. P. Chuloshnikov, "Feodalnye Otnesheniia v Bashkirii i Bashkirskie Vosstaniia 17 i Pervoi Poloviny 18 vv." Materialy po Istorii Bashkirskoi Istorii, part 1, Bashkirskie Vosstaniia v 17 i Pervoi Polovine $18 v v$. (Moskva\&Leningrad: Izdatel'stvo Akademii Nauk SSSR, 1936), 54.

${ }^{33}$ Materialy po Istorii Bashkirskoi ASSR, v.6, (Ufa: Kitap, 2002), 96.

${ }^{34}$ I. G. Akmanov, "Organizatsiia Orenburgskoi Ekspeditsii i Nachalo Vosstaniia 1735-1740 godov" in Ocherki Istorii Dorevoliutsionnoi Rossii, v. 2, ed. R. V. Filippov (Ufa: Bashkirskii Gos. Universitet, 1975), 123
} 
because he thought that these meetings were about recruiting labor force for the construction of the fortresses. One reason for his indifference to the reports about the Bashkir threat was that he was more engrossed with the Kazakhs and ignored the Bashkirs' rebellious potential. ${ }^{35}$ Kirilov made himself believe that Bashkirs were fully dormant and were extremely pleased (ves'ma dovol'nyi). ${ }^{36}$ This could be possibly explained by the arrogance of an imperial official alien to the region's conditions who had been assigned the task of changing the fortunes of the largest empire of the time, and the Bashkir threat was only a trivial issue for such an elevated man. Even though he highhandedly attempted to recruit a number of Bashkir elite leaders to the Russian service, his arbitrary manners only antagonized disgruntled Bashkir leaders.

There was more than a cultural gap between indigenous peoples and the representatives of the central government. The authors of the unrealistic projects in the region refused to incorporate the cooperation of the local elite and this caused a catastrophe for the peoples of the region, Russians and non-Russians alike. As the leader of the Orenburg expedition, Kirilov was possibly aware of Volynski's ideas and he also proposed similar plans in one of his reports to the Senate dated 13 January 1735 . One of his plans was to send Bashkirs to perform long military service away from their families and wives who would lose their fertility and produce no children and this way the number of Mukhamedans would be reduced. The government decided to send Bashkirs who

\footnotetext{
${ }^{35}$ Alton Donnelly, The Russian Conquest of Bashkiria: A Case Study of Imperialism, (New Haven and London: Yale University Press, 1968), 67.

${ }^{36}$ V. N. Vitevskii, I. N. Nepliuev i Orenburgskii Krai v Prezhnem Ego Sostave do 1758 g. (Kazan, 1897), 141.
} 
committed theft to Rogervik. ${ }^{37}$ What is surprising is that the report was penned long before the eruption of the armed hostilities. One of Kirilov's tasks in the region may have been to break the rebellious spirit of the Bashkir people as a secondary goal. ${ }^{38}$ Without providing the security of the rear it seemed impossible to leap into the affairs of Central Asia. It is certain that without a pacified Bashkiria there could be no viable Orenburg project. So the long term goals of the construction of Orenburg and its projected benefits for the imperial policies of the Russian empire were dedicated to the Bashkir question.

If the authors of the Ocherki po Istorii Bashkirskoi ASSR are to be credited, the central government as early as the 1720 s and early 1730 s had already lost its trust of the Bashkirs of southern Bashkiria and had decided to weaken them and break their influence on the Bashkir masses. ${ }^{39}$ Kirilov was a perfect choice to implement this policy. A selftaught man from modest background, Kirilov was a hardliner and refused to adopt a resilient policy towards Bashkirs because he interpreted it as a sign of weakness. He also considered Bashkirs as part of the multinational Russian empire and accordingly, despite their rebelliousness, they had to be tamed and made loyal subjects of the empire. The Russian government had conducted diplomatic negotiations with the Bashkir leaders after the 1662-1664 war and treated them as equals in the peace talks and exchanged prisoners, all of this was the evidence of the recognition of Bashkirs as negotiable opponents.

\footnotetext{
${ }^{37}$ Materialy po Istorii Bashkirskoi ASSR, v. 3, (Moskva \& Leningrad: Izdatel'stvo Akademii Nauk, 1949), 494; Rogervik was a port town in modern day Estonia.

${ }^{38}$ Although the decree by the senate extensively talks about the necessity of establishing relations with the Kirgiz-Kaisaks, it does not mention further need to integrate the region firmly into the empire. However there is a strict emphasis on the need to develop the economic potential of the region. See; PSZ, v. 9, No: 6576

${ }^{39}$ N. G. Ustiugov, et., al., Ocherki po Istorii Bashkirskoi ASSR, v. 1, part 1, (Ufa: Bashkirskoe Knizhnoe Izdatel'stvo, 1956), 171.
} 
Kirilov stood firm in his attitude despite the opposition of the chairman of Commission of Bashkir Affairs ${ }^{40}$ at the time, A. I. Rumiantsev, in fact a quite brutal administrator, who was in favor of opening negotiations with the Bashkir rebels. ${ }^{41}$ Nevertheless unlike Kirilov, Rumiantsev was more of a soldier than a political figure who wanted to put an end to armed hostilities by any means including negotiations with the rebellious Bashkirs. Such a scheme was unacceptable to Kirilov who firmly believed in the necessity of binding Bashkiria to the center and making it an integral part of the empire.

For Kirilov a brutal policy was needed to integrate Bashkirs into the Russian Empire. In his view, fewer Bashkirs meant firmer integration. He was backed by the government and was authorized to implement a number of measures to this end in a governmental ukaz dated February 11, 1736 which opened the way for the settlement of merchants and artisans from Central Asia and parts of Russia in Orenburg, (It was called Or' at the time) from Central Asia and parts of Russia. The ukaz stated that all measures must be taken to make conditions better for the merchants of central Asian cities in Orenburg, a place which must be made more attractive for the merchants; Measures must

\footnotetext{
${ }^{40}$ This organ was founded in 1735 with the ukaz of the Empress Anna upon the appointment of A. I. Rumiantsev to the region specifically to cope with the rebellion. Its headquarters were in Menzelinsk which at the time grew infamous with its torture cells in its prison's dungeons where many Bashkir leaders perished like Akai Kusiumov. It existed side by side with the Orenburg expedition (later Commission) and dealt with the regular army operating in Ufa uezd. The chairman of the Commission was the head of the all armed forces in Bashkiria. This Commission was also responsible with the investigation and the trial of the participants of the rebellion. For this reason it was sometimes called Trial Commission of Menzelinsk. It lost its reasons of existence by 1742 and it was disbanded. See; Materialy po Istorii Bashkirskoi ASSR, v. 4, Part 1: Ekonomicheskie Sotsial'nye Otnosheniia v Bashkirii i Upravlenie Orenburgskim Kraem v 50-7--kh Godakh 18 v., (Moskva: Izdatel'stvo Akademii Nauk, 1956), 392.

${ }^{41}$ B. A. Aznabaev, Integratsiia Bashkirii v Administrativnuiu Strukturu Rossiiskogo Gosudarstva (Vtoraia Polovina 16-Pervaia Treti 18 vv.), (Ufa: RIO BashGU, 2005), 182.
} 
be taken to facilitate the stay of the merchants of central Asia, if necessary they must be given land for their settlement and must be treated with care. ${ }^{42}$

This invitation of Central Asians to Orenburg, historically Bashkir lands, is a clear indication of the Russian authorities' determination to put an end to Bashkir autonomy and to make Bashkirs, whether they wanted such a scheme or not, obedient and docile subjects of the empire. This law also indicated that there would be no more concessions to the Bashkirs. Probably because they did not know of this law, Bashkir leaders continued to demand the restoration of their former privileges.

This law was also an indication that Russian authorities considered the Bashkir frontier closed. They were wrong because borders and frontiers are two different things. Even if the construction of the Orenburg line sealed the fate of the indigenous people within the empire, their struggle continued. As Mario Apostolov elaborates, "Sovereign state borders and civilizational frontiers are mental constructions which frame societal and spatial limits within which social organization become possible. But, it is much more difficult to define civilizational frontiers than for example state or administrative frontiers. ${ }^{, 43}$ Based on his arguments it can be stated that the Bashkir frontier in the 1730s was taking a different form in Russia where previously unseen/unavailable divisive factors came to the surface; and the Bashkirs' Russian frontier gained new dimensions like civilized versus barbarian or Christian versus Muslim. And as the intruder gained military and economic strength and accordingly self-confidence, it became increasingly vociferous in its outlook to the indigenous peoples. The Russians now to a degree saw

\footnotetext{
42 PSZ, v. 9, No: 6889.

${ }^{43}$ Marion Apostolov, The Christian-Muslim Frontier: A Zone of Contact, Conflict or Cooperation. (London and New York: Routledge\&Curzon, 2004), 1.
} 
the native population as untamed and needing to be educated and civilized along the lines of contemporary Europeans and Russians. The Russian attitude towards Bashkirs and their brethren was now more and more paternalistic, a father figure who knew the best for the children and knew how to be brutal.

I. G. Akmanov argues that the expedition was called "The Certain (Izvestnyi) Expedition" because the Russian authorities intended to conceal the real targets of the expedition. ${ }^{44}$ In order to gain the sympathy of the local population, once Kirilov arrived in Ufa, he punished those Russian officials who had treated indigenous people arbitrarily. On the other hand he tried to gather the Bashkir elite to his side with the distribution of gifts and titles. Before his arrival in Ufa, however, the Bashkir groups had already been warned by some of their fellow Bashkirs who had been in the service of the Russian state. They were well-informed about the goals of the expedition and the possible consequences of the completion of such a project. It would mean their complete isolation from the rest of the independent Turkic world and the loss of their bargaining power in imperial circles to preserve their votchina rights.

The Bashkir support had to be recruited, for they could be of great use to the Russian government as intermediaries to conduct negotiations with the Kazakhs. The Bashkirs already had a close relationship with the Kazakhs despite the earlier armed conflicts in these two nomadic steppe societies. These potential uses of Bashkirs to the Russian imperial designs were voiced by Kirilov. Kirilov lacked the tact of his successors in his views and attitudes towards Bashkirs. But he set a precedent for the future governors of Orenburg. If Russia wanted to play a dominant role in central Asia

\footnotetext{
${ }^{44}$ I. G. Akmanov, Bashkirskoe Vosstanie 1735-1736 gg. (Ufa: Bashkirskoi Gosuniversitet, 1977), 26.
} 
and bring them to the orbit of the Russian empire, Bashkiria must be pacified and Bashkirs must be integrated into the Russian imperial system. Accordingly Kirilov briefly toyed with the idea of buying Bashkir loyalties by distributing gifts, titles, rewards, not with great success however. ${ }^{45}$

Even though in the steppe politics of the region Kazakhs were their sworn enemies, Bashkirs suffered from repeated Kazakh raids, and both were ready to clash with each other over the meager pasture lands, the Bashkirs also benefited from their connection with the Kazakh world. Their relations were not always hostile. There were trade relations, and occasionally Kazakh and Bashkir groups would join to raid Russian settlements in the region, enslave people, and sell them in the Central Asian markets. Kirilov in his report to the Senate stated that "these people (Kazakhs) are no friends (nepriateli) to us and they continually attacked Russian, Kazan, Iaitsk, Volga, Ufa and Siberian frontier settlements in small bands of thieves, causing material damage. They annually drove cattle and captives to be sold in the Bukharan and Khivan markets.",46 Bashkirs without doubt provided logistical and scouting support for these raids and benefited from these combined efforts.

During the Russo-Bashkir conflicts the Bashkir ringleaders and warriors often would take refuge among the Kazakhs, getting a breathing space for themselves to refresh their struggle against Russians again. The examples of this type of protection abound. Bashkir leader Seit took refuge among Kazakhs in the 1680s after his war effort was defeated by Russians. His sons emerged from among Kazakhs in the following decades

\footnotetext{
${ }^{45}$ B. A. Aznabaev, Integratsiia Bashkirii v Administrativnuiu Strukturu Rossiiskogo Gosudarstva (Vtoraia Polovina 16-Pervaia Treti 18 vv.) (Ufa: RIO BashGU, 2005), 185

${ }^{46}$ M. G. Masevich, Materialy po Istorii Politicheskogo Stroia Kazakhstana, v. 1, (Alma-Ata: Izd-vo Akademii Nauk Kazakhskoi SSR, 1960), 22-23.
} 
and resumed their father's struggle against the Russians. ${ }^{47}$ In 1737 , one of the leaders of the Bashkirs, Sultanmurat Diuskeev from Iurminskii Volost of Kazan Doroga took refuge among Kazakhs of Middle Horde and lived there until 1739. In the meantime he tried to provide greater Kazakh support for the Bashkir case. A Russian report about Sultan Murat and other Bashkirs among the Kazakhs states "The leading Bashkir thief, Sultan Murat, lived among the peoples of Barak sultan, from there with the end of the last winter he traveled to Urgench with the purpose of trade. However on his way to Urgench his horse killed him..... Bashkirs among the Kirgiz Kaisak (Kazakhs) people of Barak Sultan are many but their exact number is not known."48

Russians' fear of closer Kazakh-Bashkir relations was reasonable but these steppe peoples had no common ground to form firmer relations because their enemies were not common. While Bashkirs were overwhelmed with the Russian intrusions, Kazakhs had deep troubles with the Mongol Dzhungar invasion from which they dearly suffered in the 1720s and they had appealed to the Russians for protection. As long as Russians remained above these steppe politics and managed to become adept at exploiting their differences, there would be no common threat to them from this direction.

The leader of the Little Horde of Kazakhs, Khan Abulkhair, vigorously acted against any kind of cooperation between Bashkirs and Kazakhs of the Little Horde and Bashkir leaders in their moments of despair could not dare send any envoy to Abulkhair

\footnotetext{
${ }^{47}$ Yakup Deliomeroglu, "Baskurt Isyanlari," in Turkler, v. 18, ed. Hasan Celal Guzel (Ankara: Yeni Turkiye Yayinlari, 2002), 430.

${ }^{48}$ Materialy po Istorii Bashkirskoi ASSR, v.6 (Ufa: Kitap, 2002), 632: Even though Barak Khan of Middle Horde Kazakhs had promised to send an army to the help of Bashkirs he did not keep his promise because he had no reasons to fulfill his promise. While his rival Abulkhair was getting Russian vassalage it would be senseless to provoke Russians.
} 
khan for help. ${ }^{49}$ This bifurcated Kazakh approach towards Bashkirs has its own reasons. The Khan of the Middle Horde could provide shelter for Bashkirs because his main antagonist was Dzhungars, not Russians, and Kazakhs of the Middle Horde had no close relations with the Russians. Any extra Bashkir population could be used against Dzhungars. But the situation in the Little Horde was complicated. For one thing Abulkhair struggled for pride of place among Kazakh hordes and his territory was adjacent to Russian Bashkiria. For another, he had also requested Russian protection against the Dzhungar threat and hoped to receive Russian help to achieve his goals. By protecting rebellious Bashkirs he would risk this much needed Russian support. Last but not least, Kazakhs of the Little Horde did not have a bright record in their relations with the Bashkirs in the past. The relations between the two had been antagonistic and both sides raided each other's territory very often. In fact warfare between Bashkirs and Kazakhs of the Little Horde was a means of economic livelihood. So there could be little probability of a steppe alliance against Russians.

But as long as the link between Bashkirs and Kazakhs remained alive there was little hope for the closure of the Bashkir frontier. So the Russians resorted to their traditional steppe frontier control tactics and raised another line of fortifications. Below is the list of Russian fortresses and strongholds constructed right in the middle of the Bashkir lands.

\footnotetext{
${ }^{49}$ Materialy po Istorii Bashkirskoi Istorii, part 1, Bashkirskie Vosstaniia v 17 i Pervoi Polovine $18 v v$. (Moskva\&Leningrad: Izdatel'stvo Akademii Nauk SSSR, 1936), 328: When Sultan Murat and a number of other Bashkir leaders took refuge in the horde of Abulkhair with their households numbering between 270 and 300, they were robbed by Abulkhair. Materialy po Istorii Bashkirskoi Istorii, part 1, Bashkirskie Vosstaniia v 17 i Pervoi Polovine 18 vv. (Moskva\&Leningrad: Izdatel'stvo Akademii Nauk SSSR, 1936), 357.
} 


\begin{tabular}{|c|c|c|c|}
\hline & & $\begin{array}{c}\text { New Trans-Kama Line 1734- } \\
1_{1736}{ }^{50} \\
\end{array}$ & \\
\hline $\begin{array}{l}\text { Strong Points } \\
\text { (Ukreplenie) }\end{array}$ & $\begin{array}{c}\text { Type of } \\
\text { Ukreplenie }\end{array}$ & Location & Composition of Garrison \\
\hline Alekseevsk & Fortress & $\begin{array}{c}\text { Samara River (Branch of Volga) and } \\
\text { its branch Bolshoi Kinel' }\end{array}$ & $\begin{array}{l}4 \text { company of Sergievsk Regiments, } \\
1 \text { company of Alekseevsk Regiment }\end{array}$ \\
\hline Kinel'skii & Redut $^{51}$ & $\begin{array}{l}\text { Reka Rodilsia Samara i Bolshoi } \\
\text { Kinel' }\end{array}$ & \\
\hline Krasnyi & Redut & Sok river (Branch of Volga) & \\
\hline Krasnoiarskaia & Fortress & Sok river & $\begin{array}{l}4 \text { company of Sergievsk Regiments, } \\
1 \text { company of Alekseevsk Regiment }\end{array}$ \\
\hline Khoroshii & Redut & $\begin{array}{c}\text { Khoroshaia River } \\
\text { (Branch of Sok River) }\end{array}$ & 1 company of Sergievsk Regiment \\
\hline Chernorechenskii & Fel'dshanets $^{52}$ & $\begin{array}{c}\text { Chernaia River } \\
\text { (Branch of Sok River) }\end{array}$ & $\begin{array}{l}1 \text { company of Sergievsk Regiment } \\
2 \text { company of Biliarsk Regiments }\end{array}$ \\
\hline Nizhnyi Orlianskii & Redut & $\begin{array}{c}\text { Orlianka River } \\
\text { (Branch of Sok River) }\end{array}$ & 1 company of Biliarsk Regiment \\
\hline Verhniei Orlianskii & Redut & Orlianka River & \\
\hline Surovskii & Redut & Sok river and its Branch Surgut river & \\
\hline Sergievsk & Fortress & Sok River & $\begin{array}{l}3 \text { company of Biliarsk Regiments } \\
1 \text { company of Alekseevsk Regiment }\end{array}$ \\
\hline Zainskii & Redut & $\begin{array}{c}\text { Lipovka River } \\
\text { (Branch of Kondurcha River) }\end{array}$ & 1 company of Biliarsk Regiments \\
\hline Surushskii & Redut & $\begin{array}{c}\text { Malyi Surush River } \\
\text { (Branch of Sok River) }\end{array}$ & 1 company of Biliarsk Regiments \\
\hline Kondurchinskii & Fel'dshanets & $\begin{array}{c}\text { Kondurcha River } \\
\text { (Branch of Sok River) }\end{array}$ & $\begin{array}{c}1 \text { company of Sheshminsk } \\
\text { Regiment, } \\
2 \text { company of Biliarsk Regiment }\end{array}$ \\
\hline Tarkhanskii, 1'oi & Redut & $\begin{array}{c}\text { Bolshoi Tarkhanka River } \\
\text { (Bolshoi Cheremshan river basin) }\end{array}$ & $\begin{array}{l}1 \text { company of Sheshminsk } \\
\text { Regiment, }\end{array}$ \\
\hline Tarkhanskii, 2'oi & Redut & $\begin{array}{c}\text { Iaurka River } \\
\text { (Branch of Bolshoi Cheremshan } \\
\text { River) }\end{array}$ & $\begin{array}{l}1 \text { company of Sheshminsk } \\
\text { Regiment, }\end{array}$ \\
\hline Cheremshanskaia & Fortress & $\begin{array}{l}\text { Bolshoi Cheremshan River } \\
\text { (Branch of Volga) }\end{array}$ & $\begin{array}{c}3 \text { company of Sheshminsk } \\
\text { Regiment, } \\
1 \text { company of Alekseevsk Regiment }\end{array}$ \\
\hline Sheshminskii & Fel'dshanets & $\begin{array}{c}\text { Shehsma River } \\
\text { (Branch of Kama River) }\end{array}$ & $\begin{array}{c}3 \text { company of Sheshminsk } \\
\text { Regiment, } \\
1 \text { company of Alekseevsk Regiment }\end{array}$ \\
\hline Kichuiskii & Fel'dshanets & $\begin{array}{c}\text { Kichui River } \\
\text { (Branch of Sheshma River) }\end{array}$ & $\begin{array}{c}3 \text { company of Sheshminsk } \\
\text { Regiment, } 1 \text { company of Alekseevsk } \\
\text { Regiment }\end{array}$ \\
\hline
\end{tabular}

Then to this line another string of fortresses was added, this time surrounding the Bashkir lands and cutting their ties with the Kazakhs. John LeDonne argues that this new

\footnotetext{
${ }^{50}$ I. G. Akmanov and Aznagul Uruskulov, ed. Bashkirskaia Entsiklopediia, v. 3 (Ufa: Nauchnoe Izdatel'stvo, 2005), 18.

${ }^{51}$ Redut is an earthen quadrangular field fortification with the shaft, a moat and a shallow mound in front of it.

${ }^{52}$ Feld'shanets is earthen quadrangular field fortification.
} 
trans-Kama line became obsolete as soon as it was constructed because the Orenburg expedition shifted Russian attention further to the southeast. ${ }^{53}$ This view misses the point that the fortresses and forts that made this line did not lose their functionality and very effectively crippled Bashkir movement within Bashkiria. They enabled the Russian authorities to increase their grasp of the Bashkir lands and open these lands for further colonization so the integrative role of this line cannot be denied.

The turning point in this period was the construction of the Orenburg line. Peter the Great's heritage was an inspiration because Kirilov, in charge of building this line, was a close disciple of Peter the Great. ${ }^{54}$ On the other hand, another disciple of Peter the Great proposed this line be built: Vasily Nikitich Tatishchev, considered the father of Russian history writing and one of the great imperial officials that the region ever had. In a report to the government he proposed that the construction of a line be furnished with towns and settlements. Only after such a complex scheme the true colonization of the region could be accomplished. The line would provide the security of the region and

\footnotetext{
${ }^{53}$ John Ledonne, "Russia's Eastern Theater, 1650-1850: Springboard or Strategic Backyard" Cahiers du Monde Russe, v. 49, no: 1, (2008), 28.

${ }_{54}$ There are strong evidences that the father of the idea of constructing a defensive line which would isolate Bashkirs from their Kazakh kin was Kutlu-Muhammad Tevkelev, a Tatar convert in the Russian service who was sent to Kazakh leader, Abulkhair khan, to conclude an agreement that finalized Kazakhs' submission to the Russian state in October 1731. He sent a report to the college of Foreign affairs (Kollege Inostrannykh del) dated 1732 in which he stated that there was a need to construct a fortress at the mouth of the River Or because Kazakh leaders refused to send their amanats to Ufa...... and this fortress would spread fear to the hearts of the enemies of Russians within the Kazakh community and deliver a sense of safety to the Kazakh clients of the Russian state. Also this fortress would enable Russians to reach Central Asian markets in Khiva, Bukhara, Tashkent and Turkestan with utmost safety because this fortress would be far closer to Khiva than Astrakhan. See: F. N. Kireev, compiler, Kazakhsko-Russkie Otnosheniia v XVIXVIII vekakh; Sbornik Dokumentov i Materialov (Alma-Ata : Izd-vo Akademii nauk Kazakhskoi SSR, 1961), No: 40, 96; S. U. Taimasov, "Rol' Orenburgskoi Ekspeditsii v Prisoedinenii Bashkirii k Rossii (1730-e gg.)" Voprosy Istorii, 2, (2008), 145-146; M. G. Novlianskaia argues that Orenburg project was the work of Ivan Ivanovich Kirilov, a leading Russian polymath enlightened official but he indirectly accepts that Kirillov started his project seriously only after he got the report of Tevkelev who had returned from his Kazakh mission in early 1733. M. G. Novlianskaia, Ivan Ivanovich Kirilov, Geograf 18 Veka (Leningrad: Nauka, Leningradskoe otd-nie, 1964), 96.
} 
settlements, towns, cities would transform the region ethnically, socially, economically and politically. Without settlements the region could remain only a military zone populated by soldiers and an antagonistic and nomadic people.

To minimize Bashkir threats to Russian security in the area Tatishchev maintained the need for assimilating Bashkirs in a period over the generations by proposing to "take all the children of the influential families and educate them in Russian language" But Tatars as tutors should not be trusted. Instead of Tatars, Russians must have been employed as tutors on the condition that they were not drunkards since such people were considered abominable by indigenous people. For assimilation of these people, conversion to Orthodoxy was also considered as an option. It contemplated that their Christianization must be guaranteed through a certain method of toleration and understanding. In time they will better inculcate. "Besides force must not be used in proselytizing but compassion and clemency must be utilized to teach the student the rules of Christianity ${ }^{, 55}$ For the first time a top ranking Russian official from the new generation of enlightened bureaucrats was proposing to solve this problem through assimilation of the whole Bashkir people in such a way that their conversion would be ensured through peaceful ways rather than imposing the arbitrary will of the intruder. The case to make this region an indivisible part of the empire was discussed by many Russian officials who were familiar with the conditions of the region. Tatishchev as a genuine enlightened Russian bureaucrat also saw the need to transfer Russian population to the region because simply construction of the fortification systems would not suffice to

${ }^{55}$ Materialy po Istorii Bashkirskoi ASSR, v. 3, (Moskva \& Leningrad: Izdatel'stvo Akademii Nauk, 1949), 481-482. 
ensure Russian security. The Russian military existence in Bashkiria would need support by a loyal population.

There were good reasons to believe that loyal Bashkirs were not loyal or productive enough to provide food and other provisions to the garrisons because their level of sedentarization did not produce enough grain for provisioning the garrisons. Tatar or Mishars were more preferable in this respect and from the very beginning Mishars fought on the side of Russians who promised them land in the Bashkir region.

\section{The apogee of Russo-Bashkir Conflict: the 1735-1740 War}

As mentioned earlier, the 1730 s were a turning point for both Russians and Bashkirs. This turning point came because for the first time central authority firmly imposed its terms on this indigenous people in a bloody war that had three stages: 1735$1736,1737-1738$ and 1738-1740. It was the greatest and the bloodiest war between Bashkirs and Russians, the starting point of which for the Bashkirs was to prevent Russian encirclement of the area. The fact was that even though during these three different stages several different Bashkir leaders emerged and nearly all of them were killed or executed by the punitive forces, the goal (evicting the Russians from Bashkir lands) remained the same. Accordingly the phases of this war must be considered connected.

One other aspect of this war was that it was also a war between mainly two rival Bashkir groups; pro-Russian and anti-Russian. Even though in the previous RussoBashkir wars there were tensions and armed conflicts among rival Bashkir factions, in the 1730s the scale of this infighting reached an extraordinary level. Nearly a whole society was polarized between loyal and rebellious Bashkirs. This polarization was also not 
confined to the Bashkir people. Other non-Russian groups in the region had undergone a similar polarization. Bashkir rebel groups never hesitated to storm Mishar, Tatar or loyal Bashkir auls (villages) which refused to join them. This was partly working to the advantage of the rebellious Bashkir groups who had no or meager provisions because loyal indigenous settlements were not burned down or sacked by the Russian forces so there was food available in these places. ${ }^{56}$ Even though Mishar groups were mostly in the Russian service, a number of them preferred to fight on the side of the rebellious Bashkirs. A Tatar mulla called Urazmet wrote in his report to the Russian officials in Ufa about an incident when he was briefly captivated by disloyal Bashkir groups where he noticed Mishar fighters in the rebel camp.${ }^{57}$ Tatars had been divided among themselves as well. According to the report of a captivated Tatar rebel called Arslan by the Russian forces, in his native region in Kazan Uezd, which was located just outside the original Bashkir lands, fourteen Tatar villages agreed to join rebels. ${ }^{58}$

The 1735-1740 rebellion was bloody and almost no one in Bashkiria was unaffected by the destruction. This war was good evidence for the new imperial historiography because it was not simply between Russian oppressors and the freedom loving peoples but was more complex and differentiated. Rebellious Bashkirs fought against the Russian settlers, the Russian government, the loyal (vernyi) Bashkirs and other ethnic groups, i.e. Tatars and Mishars. Some groups of Tatars and Mishars fought the Russians and cooperated with the rebellious Bashkirs. In August 1735, Bashkirs from a number of volosts in Nogai Doroga and Kazan Doroga, Tatars from a number of

\footnotetext{
${ }^{56}$ I. G. Akmanov, ed., Istoriia Bashkortostana s Drevneishikh Vremen do Nashikh Dnei v Dvukh Tomakh, v. 1, (Ufa: Kitap, 2007), 175.

${ }^{57}$ I. G. Akmanov, Bashkirskoe Vosstanie 1735-1736 gg. (Ufa: Bashkirskoi Gosuniversitet, 1977), 35.

${ }^{58}$ I. G. Akmanov, Bashkirskoe Vosstanie 1735-1736 gg. (Ufa: Bashkirskoi Gosuniversitet, 1977), 38
} 
villages and Chuvash from the village of Ulu Arema, in total more than one thousand people, destroyed two Bashkir, three Tatar and three Mishar villages. ${ }^{59}$ Loyalties constantly shifted in this case and there were no fixed boundaries between enemies. One day's enemy could easily be other day's ally.

The 1735-1740 war could perhaps be classified as a genuine frontier war because militarily weaker and disorganized rebels first and foremost direct their hostilities to the easier targets, that is to say to the settlements of the loyal groups. This was the main method of the war in the frontier. This rebellion also proved that large-scale armed rebellions could be extremely costly for the natives. The rebellious Bashkirs resorted to guerilla-style warfare because of their military weakness and backwardness or lack of training. Since they were heavily depended on the settlements for provisions they were also extremely vulnerable to the Russian punitive expeditions. It is by no means an exaggeration to say that casualties among non-combatant Bashkir population substantially exceeded those among Bashkirs who actually fought.

As a result of the unbending policy of Kirilov, some 12 to 14 percent of the Bashkir population perished. More than 60.000 were killed, executed, enslaved or died of starvation and exposure. ${ }^{60}$ It must be added here that there is not one common universal view about the exact population of the Bashkirs. The cruelties of the Russian commanders, in particular Orthodox Tatar convert Tevkelev's, were told in the folk songs of Bashkirs of the period in a bitter tone.

Our land Tevkelev scorched The valley of Ak-Idel he burned

\footnotetext{
${ }^{59}$ I. G. Akmanov, Bashkirskoe Vosstanie 1735-1736 gg. (Ufa: Bashkirskoi Gosuniversitet, 1977), 42-43 ${ }^{60}$ R. G. Kuzeev, Istoricheskaia Etnografiia Bashkirskogo Naroda (Ufa: Bashkirskoe Knizhnoe izd-vo, 1978), 154.
} 
He simply burned Bashkirs

The golden epaulettes fell on the shoulders. ${ }^{61}$

In January 1736, Tevkelev's troops committed unspeakable atrocities, as was reported by P. I. Rychkov, a firsthand witness of the 1735-40 Russo-Bashkir war and the first historian of the Orenburg region. Seiantus was a Bashkir village in the Sibir doroga which was pro-rebel, and its able bodied males had joined the rebel forces. To set an example for the other Bashkir settlements in the region, Tevkelev stormed this largely defenseless village. Rychkov's accounts of the events are revealing of the Russian intentions and methods in the region. "They, Bashkirs, were all surrounded by us. After brief resistance they were all captured, nearly 1000 people with their women and children. Women and children were taken away and hacked to pieces with bayonets by loyal Bashkirs and Mishars." Over 105 people were taken into a barn and it was burnt down with people inside. All these happened in one night. However the most surprising thing was that, for Rychkov, even within the barn those thieves, Bashkirs, managed to wound some dragoons with their spears which they hid in the barn. At the end of the night there was nothing but ashes left from this once large village. Everybody young or old was killed. ${ }^{62}$ Even though Rychkov claims nearly one thousand dead, this figure is highly dubious since Bashkir villages were at most a quarter of this population a half century later.

\footnotetext{
${ }^{61}$ R. G. Kuzeev \& B. Kh. Iuldashbaev, 400 Let vmeste s Russkim Narodom; Prisoedinenie Bashkirii $k$ Russkomu Gosudarstvu i ego Istoricheskoe Znachenie, (Ufa: Bashkirskoe Knizhnoe izd-vo, 1957), 81.

${ }^{62}$ P. I. Rychkov, Istoriia Orenburgskaia, 1730-1750, (Orenburg:1896), 20.
} 
Bashkir rebel groups attacked Russian settlements to seek the revenge for the massacres of Tevkelev and Kirilov, ${ }^{63}$ but these settlements did not suffer as heavily as the non-Russians. I. G. Akmanov argues that this proved the anti-government nature of the war by the rebels. He concludes that Bashkirs' hostility was not directed against the Russian people. However he ignores the nature of the Russian settlements. For one thing Russian peasants for security reasons had settled in the lands surrounding Russian fortresses and their major function for that reason was to produce food needed for the supply of the armed forces. So they were less vulnerable to the attacks of the rebels. For other, while the Russian government prohibited the sale of arms to the indigenous people and the blacksmithery was forbidden to the natives, the government imposed no similar limitation on the Russian peasants. So the Russian settlements could better defend themselves against the incursions of the rebels. From the very beginning Bashkir rebellions had been directed against all types of settlements that prevented them from performing their traditional nomadic lifestyle and Russians had never been an exception for their hostilities.

The story told by Kidras Mullakaev ${ }^{64}$ after an incident is revealing in this respect. Kidras, a Bashkir noble in the service of the Russians, with his companions attempted to

\footnotetext{
${ }^{63}$ I. G. Akmanov, ed., Istoriia Bashkortostana s Drevneishikh Vremen do Nashikh Dnei v Dvukh Tomakh v. 1, (Ufa: Kitap, 2007), 177

${ }^{64}$ Kidras Mullakaev (ca 1700-1789) was a Bashkir starshina who served Russians loyally and took part in the suppression of the Bashkir revolt in 1735-1740 and then joined Russia's war effort during the Seven Years' War but then he felt alienated and joined to the Pugachev's rebellion in the 1770s and participated in a number of expeditions against Russian strong points. He, however, abandoned the rebellious groups also and started fighting against them as of April 1774 and he even defeated a small force of the rebels. Mullakev again showed up in the rebellious camp fought against the governmental forces. Again for the last time he switched sides and in August 1774 he captured one of the renowned Bashkir leaders from the rebellious camp, Kanzafar Usaev. He was briefly investigated by the Kazan Secret Committee and set free in the spring of 1775 and given the strashina position of the Karatabynsk volost. He proved to be a really revealing weathercock individual who personified the fluid character of the life in frontier areas.
} 
join Kirilov's expedition. On his way to Kirilov's camp, he was captured by a "disloyal" Bashkir group from the Nogai doroga and was released only after he promised not to help the Ufa administration, a promise he did not keep. He rushed to the Russians and explained what he witnessed in the Bashkir camp. He claimed that Bashkirs had been divided among themselves and some groups of Bashkir leaders were planning to exterminate those collaborators, loyal Bashkir nobles. ${ }^{65}$

The Russian authorities were extremely adept at exploiting this cleavage within Bashkir society, and the magnitude of hostilities within that society contributed greatly to the government's success in suppressing this rebellion. Since the modest Russian armed forces were inadequate to subdue the restive Bashkir tribes which composed much of the population of the region, it was vital for them to rely on the loyal elements of the Bashkir society. The division within the Muslim community in the region gained momentum and loyal elements within the indigenous groups with their families started moving into the Russian fortresses to escape death at the hands of the disloyal groups.

I. G. Akmanov argues that the Bashkir rebellions of the 1600s and 1700s were not directed against the Russian people in the region but against the Russian government. Akmanov is much less tolerant of the Tatar groups because, he maintains, these Tatar groups, especially their feudal leaders, were collaborators who attempted to seek protection of the Russian forces. On the other hand he maintains that the religious establishment in the region, mostly composed of Tatars, was pro-Russian during this war and Bashkir groups intermittently killed them while they were serving Russians against

${ }^{65}$ I. G. Akmanov, "Novyi Dokument o Nachale Bashkirskogo Vosstaniia 1735-1740 gg." Iuzhnoural'skii Arkheograficheskii Sbornik, no: 2, (Ufa: 1976), 344. 
their Bashkir brethren and coreligionists. ${ }^{66}$ In the same way, some of the Bashkir tarkhans who had declared their loyalty to the Russian government and promised to join the expedition were attacked by the rebellious groups. In some cases they were killed and as in the case of Kidras Mullakaev they were released only after they promised to cease to support Russians. These hostilities prevented any possibility of a unity of indigenous peoples against the intruding Russians.

The Russians had managed to divide indigenous communities by distributing lands which did not belong to them. Kirilov proposed to kill rebel Bashkirs with their wives and children and distribute their lands to Russian settlers, Tatars and loyal Bashkir nobles who served governmental forces in suppressing rebellion. Also on the Bashkir lands fortresses must have been established with the Mishar settlements in the vicinity. The promise of distribution of gifts had a devastating effect not only on the Bashkirs but also other non-Russian societies in the region. But winning the loyalties of a minority of Bashkirs was not good enough because the rebellious potential of the Bashkirs continued. Because the allegiances in the frontier areas were extremely fluid, those loyal Bashkirs could not be trusted fully. A more radical plan by Kirilov was proposed in the summer of 1736 to reduce the density of the Bashkir population in the region by opening their lands to colonization, which would dilute Bashkirs' demographic dominance in the region. When their lands were distributed to the Russian peasants and Mishars they would be forced to mix with them and would lose their rebellious spirit. ${ }^{67}$

Kirilov's proposal would have been the most reasonable solution to Russia's Bashkir problem, but that objective could have been realized only after a generation

${ }^{66}$ I. G. Akmanov, Bashkirskoe Vosstanie 1735-1736 gg. (Ufa: Bashkirskoi Gosuniversitet, 1977), 35

${ }^{67}$ A. Dobrosmyslov, Materialy po Istorii Rossii, v.2, (Orenburg :1900), 82-83. 
during which Bashkirs became fully familiar with a sedentary society. If it could have been started, the achievement of such a program could have fully closed the frontier in this area. At least the frontier, even if it did not disappear fully, could have been internalized, that is to say, the frontier society could lose their ties with the people beyond the control of the government. The frontier could gain a new, religio-cultural dimension in which indigenous people after losing their means and hopes to solve the problem of the intruder revert to cultural areas and attempt to preserve their distinct religious and cultural ways.

Last but not least up until the 1730s the Bashkir groups had increasingly sedentarized and accordingly their settlement became the targets of punitive expeditions. During the rebellion Russian punitive forces burned or otherwise destroyed many Bashkir villages. Sedentarization of Bashkirs made them more vulnerable to the Russian attacks and less capable of conducting a successful guerilla warfare based on hit and run tactics.

The Russian imperial historians by and large called this war a bunt, riot or peasant rebellion. While the nineteenth century Russian historian, N. Firsov based his views on struggle between European civilization and Muslim fanaticism and Asian barbarism, ${ }^{68}$ for others historians of the same period, Russia had the mission to insert the elements of European civilization among these barbarians and had to be the carrier of the message of the New Testament in the spirit of the Orthodox Church. ${ }^{69}$

\footnotetext{
${ }^{68}$ N. Firsov, Inorodcheskoe Naselenie Prezhnego Kazanskogo Tsarstva v Novoi Rossii do 1762 g. $i$ Kolonizatsiia Zakamskikh Zemel' v Eto Vremia (Kazan; 1869)

${ }^{69}$ V. N. Vitevskii, I. N. Nepliuev i Orenburgskii Krai v Prezhnem Ego Sostave do 1758 g. (Kazan, 1897),118;; A. I. Dobrosmyslov, "Bashkirskii Bunt v 1735, 1736 i 1737 g." Trudy Orenburgskoi Uchenoi Arkhivnooi Kommissii, no: 8, (Orenburg: 1900), 3-4; Dobrosmyslov does not count Orenburg project as the immediate reason for the outbreak of war, though he calls it bunt (riot), but he rather considers century long Bashkir dissatisfaction with the rising tide of fugitive peasants who destroyed traditional Bashkir way of life.
} 
Bashkir leaders of the first stage were Kilmiak Nurushev, one of the leaders of the 1704-1711 rebellion, ${ }^{70}$ Akai Kusiumov, the son of the famed Kusium Tiukeleev, the hero of the 1704-1711 war and ${ }^{71}$ Iusup Arykov. ${ }^{72}$ Their deaths at the hands of the Russians reveal the lack of institutional basis of the steppe politics. All these unsuspecting leaders were lured into the hands of Russian authorities and they all perished. So it was highly possible that the lack of an institutional basis and the predominance of personal relations between Russians and indigenous people was a basic aspect of the frontier life.

Other more obscure Bashkir leaders troubled government forces for a long time. One of them was Bepenia Trupberdin. He was from Sibir doroga and in a sense he was one of the main ideologists of the Bashkir cause as a literate abyz. Just like Kilmiak Nurushev he grasped the main direction of this Bashkir movement and heavily criticized Russian officials in the region for their violation of the votchina law of Ivan IV. In his letter to Tatishchev in August 1736 he clearly defined the reasons of their movement, blaming Tatishchev for establishing factories in his own native region and eliminating traditional Bashkir life. He attempted to conclude an alliance with the Lesser and Middle

\footnotetext{
${ }^{70}$ Kil'miak Nurushev was from Nogai Doroga. He was within the envoy who conducted meetings with the Crimean Tatar Khan in the 1704-1711 rebellion. He was a Bashkir noble and an Abyz, Mullah and Batyr. These qualities enabled him to exert a certain degree of religious and martial influence on the Bashkir masses. Since he was an extremely respected figure in the Bashkir society, he managed to summon allBashkir Iighin in December 1734 to provoke the war against Kirilov's Orenburg expedition thereby becoming the leading ideologist of the war effort. He was arrested in February 1737 when he visited the fortress of Tabynsk. He had believed that he would conduct negotiations with the Russians. He was duly packed to St. Petersburg where he was executed in 1738.

${ }^{71}$ Akai was arrested in the Menzelinsk fortress while attempting to mediate between Russian officials and Bashkir leaders. Akai was arrested in the Tabynsk fortress and later executed. Akai's grandfather, Tulekei was also an active anti-Russian Bashkir noble who led a number of Bashkir groups against the Russians during the 1680-1681 war. He was caught and executed by hanging. This family's resistance tradition was also an indicator of the formation a national Bashkir leadership. Not surprisingly, Akai Kusiumov's son Abdulla Akaev became one of the leaders of the 1755-1756 Bashkir war. His ultimate fate is not known. So four generations of a family led wars and perished.

72 Arykov was a Bashkir noble from Sibir Doroga. He was arrested by the Russian authorities when he arrived to Kyzyltash fortress to negotiate peace terms and later executed.
} 
Horde leaders of Kazakhs. He also suffered in Menzelinsk just like previously mentioned Bashkir leaders.

The major distinguishing feature of these Bashkirs was that they were all from the southern and eastern Bashkir lands where they had enjoyed to a great degree a free nomadic life unlike their brethren who led a sedentary life in western and northern Bashkiria. Russian incursions from the beginning of the $18^{\text {th }}$ century in the forms of establishing factories, constructing fortifications and carving out Bashkir lands for settlement made their lives increasingly unbearable. As we saw some of them had already developed a family tradition of fighting Russians and these leaders were from wealthy Bashkir elite who controlled traditionally large livestock herds, which needed large pasturelands. It was reported by a European traveler that as late as second half of the nineteenth century an ordinary Bashkir had twenty or thirty heads of horses; the richer Bashkir families owned at least 500 heads of horse while the richest ones would have no less than $2000 .^{73}$

Between 1735 and 1740, the Russian punitive measures caused enormous sufferings for Bashkirs. ${ }^{74}$

\begin{tabular}{|l|c|c|c|}
\hline & Orenburg Commission & Bashkir Commission & Total \\
\hline Burnt & 300 Villages & 396 Villages & 696 \\
\hline Sent to labor camps & 135 People & 3101 People & 3236 \\
\hline Executed & 7455 People & 9438 People & 16893 \\
\hline $\begin{array}{l}\text { Given to Nobles } \\
\text { (Women and children) }\end{array}$ & 2882 people & 6909 People & 9791 \\
\hline
\end{tabular}

${ }^{73}$ Robert Gordon Latham, The Native Races of the Russian Empire, (London: 1855), 155.

${ }^{74}$ A. Z. Asfandiiarov, Bashkiriia Posle Vkhozdeniia v Sostav Rossii, Vtoraia Polovina 16-Pervaia Polovina 19. v., (Ufa: Kitap, 2007), 182. Asfandiarov took these figures from Rychkov and refined them for better use for the reader. See; P. I. Rychkov, Istoriia Orenburgskaia, 1730-1750, (Orenburg: 1896), 56. 


\begin{tabular}{|l|l|l|l|}
\hline Horses and Cattle confiscated & 1097 heads & 17154 Heads & 18251 \\
\hline
\end{tabular}

The number of villages destroyed by the authorities may seem small but for a partly sedentarized community these losses were huge and the results of sedentarization were dispiriting. Though we do not know what Bashkirs thought about their losses and the causes of them, probably they were already remorseful considering the possibility that nomadism could give them greater mobility and better ability to escape before the advancing punitive forces. Once the construction of the Orenburg line was completed they could no longer take refuge among Kazakhs. In fact their effective encirclement prevented them from abandoning their homeland and from creating a large Bashkir Diaspora group. This may partly explain their lack of an enlightened Diaspora intelligentsia in the later stages of the Russian Empire which could have played a more influential role in the formation of Bashkir national formation. Thanks to the great efforts by the Jadidists and the Russian government's insistence to give at least a basic education to the local nationalities, the gap was closed to a degree. By the year 1917 Bashkir national self-consciousness still remained far behind those of Volga Tatars or Azerbaijanis.

\section{The Batyrsha Rebellion, 1755-1756}

The Bashkirs' struggle during the first half of the 1700s ended in a national disaster. The Bashkir society was more divided than ever and the lines that separated Bashkirs groups were now clearer. Despite their divisions the elements that defined Bashkir identity were still the same. The most important of these was their adherence to Islam and Bashkirs, despite Russian authorities' wishful thinking of their potential to 
convert to Christianity, remained devout Muslims at least at a confessional basis rather than reflecting their devotion to Islam at practical level. The Bashkir rebellions not only enabled Bashkirs to preserve their identity, they also helped other non-Russian peoples residing in the area preserve their identities. Because the Russians had many times faced a formidable enemy, Bashkirs, many times they had to curb their excessive policies or at least were forced to follow a more lenient policy in Bashkiria.

The Batyrsha case was the most clear-cut example of this. Right after the suppression of the Batyrsha event Russian authorities felt compelled to abandon their forced conversion policy in the Middle-Volga region which had started in the early 1740s in earnest and caused the flight of the people away from the middle Volga region to the Urals. It also caused the emergence of new convert groups who numbered in thousands especially among Volga Tatars. It made the Russian authorities reconsider their religious policies against the nationalities and under Catherine the Great a new law on religious tolerance was enacted and the brief period under this brilliant empress turned out to be a rare period of religious toleration in the whole of Russian history since Russia emerged as a political and military force in the late fifteenth century. This incident also led to the creation of an official branch in the state which specifically dealt with the Muslim affairs in the empire.

Batyrsha's ethnic background is still a matter of debate. Regional historians have presented differing accounts of his origin. It is widely believed however that he was a Mishar noble whose parents had moved to Sibir doroga of Bashkiria in the late seventeenth century to escape Russian proselytizing attempts while many of their kin in Kazan province had converted to Christianity and found themselves high positions in the 
Russian administration. So Batyrsha's parents were in a position to educate Batyrsha, born in the second decade of the $1700 \mathrm{~s}$, as a religious scholar. ${ }^{75}$ His father, Tukhtargali Dusaliev settled in Karysh in 1702 and was also a mulla. Though he received his first religious education in his native village in Sibir doroga, Karysh (now Verkhekarysh), founded by Mishars in 1693, Batyrsha in order to become a mudarris traveled widely in Russia's Middle Volga region, which may indicate Russian government's sporadic indifference to Muslim religious scholars and institutions. He spent some ten years in major madrasas of Kazan Gubernia in the 1730s and 1740s. So when the storm over Muslims of Kazan Gubernia started in 1740, he was a close witness of the events. In 1749 he returned back to his native village in Karysh and established his own madrasa, raising his own shakirds, ${ }^{76}$ and increasing his fame and influence among the indigenous people. His relations with the Bashkirs remained warm and his scholarly side was held in high esteem due to his ability to find answers relating to people's problems in religious matters.

It was not a state secret that Russian authorities time and again attempted to convert especially Middle Volga peoples which sometimes extended to the Bashkir regions of the empire. By the year 1708 the number of Tatars of Bashkiria who had been converted to Orthodoxy was about twelve thousand according to the accounts of a British diplomat who travelled in Russian at the time. ${ }^{77}$ Though this number seems exaggerated,

\footnotetext{
${ }^{75}$ There are arguments about Batyrsha that his place and date of birth and ethnicity are not known. Even his real name is matter of debate. Various accounts call him Batyrsha Aliev, Abdulla Aleev, Abdulla Miazgaldin, Gubaidulla Miagziadlin, Gubaidulla Batyrsha. See; Faizulhak Islaev, Vosstanie Batyrshi god 1755, (Kazan: Fen, 2004), 70.

${ }^{76}$ Shakird: Student of madrasa

${ }^{77}$ S. G. Runkevich, Uchrezhdenie i Pervonachal'noe Ustoristvo Sviateishego Previtel'stvuiushchego Sinoda (1721-1725 gg.), (Sankt-Peterburg: 1900), 35-36.
} 
(because the Tatar population in Bashkiria was still a small fraction of the overall population of the region.) there were Russian attempts to hunt down Tatars to convert them to Christianity. This was a policy of the government which occasionally repeated itself despite intervals of noninterference.

Since its emergence as a multinational entity after the conquest of Kazan in 1552, the Russian Empire relentlessly expanded and continued to add new nationalities into its territorial body and by the end of the eighteenth century only 49 percent of the empire was Russian. The first peoples who had been incorporated into the empire were Finnic and Turkic peoples along the Volga River basin and they remained distinct from the Russian culture and many of them even refused to learn Russian language. By the $18^{\text {th }}$ century Russian authorities viewed cultural and religious diversification as a threat to the integrity of the empire and began to try to impose uniformity through religious conversion. The first great and systematic proselytizing campaign was launched with the foundation of the Novokreshchenkaia Kontora (New Convert Office) in 1740.

The Russian state until then lacked a clearly designed conversion policy. The attitudes of the tsars varied from generation to generation. The infamously cruel tsar, Ivan the Terrible, at the height of religious zeal, ordered the conversion of Tatar people only through peaceful means. The modernizing tsar, Peter the Great, urged the use of force against the Russian Muslims, though he was anticlerical. ${ }^{78}$

The Russian volunteers who explored derelict parts of Siberia and took over those lands in the name of the sovereign Tsar encountered pagan foreigners called inozemtsy (literally people from other lands) and these first volunteers were ardent baptizers. In

\footnotetext{
${ }^{78}$ Isabella Kreindler, "Educational Policies toward the Eastern Nationalities in Tsarist Russia: A Study of Ilminskii's System" (PhD diss., Colombia University, 1969), 29.
} 
principle the conversion was supported but in practical terms Muscovite rulers were against mass conversion in the long run due to the fact that those who converted were not expected to pay Iasak in the form of fur which formed a big chunk of the Russian revenues in the sixteenth and the seventeenth centuries.

The most outrageous attempt to proselytize pagans and Muslims of this period started when Novokreshchenkaia Kontora (New Convert Office) was founded in September 1740 soon after Bashkiria was pacified by the central government. Possibly this success encouraged the government to resort to forceful conversion of the masses. With the foundation of this office, the Russian officials attacked Islam more methodically. While in the past the missionaries were encouraged to proselytize nonorthodox populations on their own initiative, in the 1740s the central authorities strongly backed them and provided necessary funds and institutions. But the government authorities recognized their limited capacity to convert all the non-Christians, so they limited the sphere of activity for this office in four provinces; Kazan, Astrakhan, Nizhnii Novgorod and Voronezh. Bashkiria, by this time Orenburg, was not included in these schemes of conversion.

The activities of this agency were violent because one of their tasks was to destroy the mosques in these regions built after 1552. As a result Russian authorities razed 418 of the 536 mosques in the region. Michael Khodarkovsky argues that those remaining 118 mosques could not be demolished for fear of a general uprising. ${ }^{79}$ In fact a substantial uprising occurred in Bashkiria when a large number of Kazan Tatars migrated to the region where the conditions for a successful rebellion were riper than in

${ }^{79}$ Michael Khodarkovsky, "Not by Word Alone" Comparative Studies in Society and History, v. 38, no: 2 , (1996), 284 
the Middle Volga region. They escaped to Bashkir lands and sought refuge among their co-believers. As a result of this mass exodus of Tatars and other non-Russian nationalities Bashkiria's demographic structure changed to the disadvantage of Bashkirs. Tens of thousands of Bashkirs had been victimized during the 1735-1740 wars and now with the rise of the population of non-Bashkirs in the region Bashkirs were reduced to a minority in their native lands. The Tatar refugees in Bashkiria were not brought back to the middle Volga region by the Russian government because authorities feared another rebellion in Bashkiria. However Bashkirs were again brewing for another rebellion against the government for some other reasons since they did not in particular suffer from the activities of the Novokreshchenskaia Kontora.

The Russian officials, clerical or secular, who served in Bashkir lands, might have dreamt of proselytizing Bashkirs but the realities of the region, the treasure's need for Iasak payments and the grant of the tsar Ivan IV conflicted with their religious zeal. All in all the Russian higher authorities never systematically attacked Islam in Bashkiria unlike their enthusiastic religious persecution of the Muslims and Pagans of the middle Volga region. The Russian methods of proselytizing often lacked sophistication. Though the tsarist officials offered various gifts to the converts most of the time conversion took place at gun point. ${ }^{80}$

The Russian Tsarina's ukaz in the early 1730s which preached forced conversion of peoples of Mid-Volga into Christianity and the Russian anti-Islamic practices in the 1740s led to Bashkirs' last great rebellion to preserve their identity. Bashkirs under Batyrsha Mulla once again rebelled in 1755-56. But this rebellion differed from the

${ }^{80}$ N. A. Abramov, "Materialy dlia Istorii Kristianskogo Prosveshcheniia Sibiri” Zhurnal Ministerstva Narodnago Prosveshcheniia, v. 81, no. 5, (1854), 15-54 
earlier great rebellions. Batyrsha was a well-educated intellectual and madrasa professor who could better grasp the desperate situation in Bashkiria. So his demands were confined to the redressing of grievances. The rebellion was crushed by the authorities without much difficulty because Batyrsha was not a battle hardened military leader but once again a Bashkir rebellion saved not only Bashkirs but also surrounding non-Russian peoples from greater damage to their cultural and religious identity. After Batyrsha incident, the Russian authorities greatly restricted the powers and movements of the missionaries in Middle Volga. The energetic leader of the proselytization movement, Luka Konashchevich was sent to Belgorod bishopric, which in fact was a demotion. ${ }^{81}$ So the governmental attack on non-Christians started which lasted until 1764 in fact ended in failure for the government. The most violent and active years of operation of this agency lasted until the eruption of the Bashkir revolt of Batyrsha in 1755. Then for the rest of its duration this office remained dormant and was finally abolished by Catherine the Great in 1764.

After these reforms, the Bashkirs' main bone of contention became the government's economic policies in the region. The most caustic economic policy of the state was the abolition of the Iasak payments in 1754 which appalled Bashkirs since they believed that their Iasak paying status guaranteed them their rights to the land without which they considered themselves demoted to the status of peasants. ${ }^{82}$

The Batyrsha revolt's main contribution to the Bashkir society was its indication of the transformation of the society since 1552. For the first time in Bashkir history,

\footnotetext{
${ }^{81}$ Paul W. Werth, "Coercion and Conversion: Violence and the Mass Baptism of the Volga Peoples, 174055”, Kritika: Explorations in Russian and Eurasian History, v. 4, no: 3, (2003), 565.

${ }^{82}$ Faizulhak Islaev, Vosstanie Batyrshi god 1755, (Kazan: Fen, 2004), 76-77.
} 
religious leaders embraced leadership of the Bashkir society. Batyrsha's movement signaled the end of the struggle for preservation of their client status. In a fully encircled Bashkiria, these people moved their struggle to another sphere away from the military field. The abolition of Iasak, the introduction of indirect taxes in salt, the motives of the uprising of Batyrsha are all evidence than Bashkirs were no more semi-independent clients of their Russian patrons but instead their subjects. Their main concern as subjects of the Russian Empire was to preserve their Bashkir identity.

\section{Conclusion}

The more Bashkirs resisted Russian incursions the more they suffered. Peter the Great's Russia visibly experienced a great transformation after 1725. The more Russian culture resembled western culture the more Russian officials became hostile to the eastern peoples. Peter's Europeanized scholar officials more ardently embraced the idea of integrating the borderlands. Culturally it was also a matter of prestige for these scholar officials to become engaged in bringing western culture to the eastern 'savages'. Russians, now as conquerors of Bashkiria, expected that an acculturation would take place and Bashkirs would be assimilated into the Russian ways. To their great surprise in some ways the opposite took place.

Peter Stern argues that the European conquerors took on some aspects of the conquered and they usually expected that acculturation would take place to be primarily in one direction - theirs. The Europeans assumed that their perceived cultural superiority 
would persuade the conquered to embrace the blessings and benefits of their European way of life. $^{83}$

Stern's assertion is partly true for the Bashkir society. While some of the Bashkir nobles chose to become agents of the Russian state and enrich themselves, the majority of the Bashkirs chose to resist in different ways when the armed resistance proved futile and too bloody. By the end of the 1750 s, Bashkirs were to a great degree were pacified and the Russian authorities, sure of their victory over the Bashkir resistance, embarked upon reforming Russian administration in the region and invited Bashkir delegates to join Legislative Commission (Ulozhennaia komissiia) of 1767.

The results of the events of this period indicate that the Russian governments from a point of military, political and economic strength dictated their terms on Bashkirs and seriously considered a drastic transformation in the economic life of Bashkirs. The authorities developed various projects to this end and Bashkirs futilely resisted them. The result could have been a total extinction if Bashkirs had pursued a relentless resistance. There emerged a thin line that separated total extinction and unconditional surrender. Bashkirs opted for the second and succumbed to the empire's transforming will but only for the time being.

${ }^{83}$ Peter Stern, "The White Indians of the Borderlands" Journal of the Southwest, v. 33, no. 3 (Autumn, 1991), 263. 


\section{Chapter 4 \\ Strange Bedfellows: Bashkirs during the Pugachev Rebellion}

The Pugachev rebellion of 1773-1775 was the largest popular rebellion in Russian

history. The rebellion affected large areas in southeast Russia, including mainly Orenburg,

Kazan, Astrakhan and Voronezh gubernias where perhaps six million people lived at the time. ${ }^{1}$

The area affected by the rebellion was about $600,000 \mathrm{~km}^{2}$, and stretched from Penza to

Cheliabinsk and from Perm Gubernia to the Caspian Sea. ${ }^{2}$ These areas were mostly non-Russian

in population despite increasing Russian immigration. Accordingly one of most salient features

of this war was the large scale participation of the non-Russian nationalities in the war, on the

sides of both the rebels and the government.

Many scholars, Russian and Western, have written studies of the Pugachev rebellion. Yet this vast literature has devoted too little attention to the important role that national groups played in the rebellion, especially Bashkirs. ${ }^{3}$ There are two main reasons for this neglect both in

\footnotetext{
${ }^{1}$ V. M. Kabuzan, Izmenenia v Razmeshchenii Naseleniia Rossii: V 18 - Pervoi Polovine 19 v. Po Materialam Revizii (Moskva: Nauka, 1971), 83-102. The author used the figures of land survey records and census results of 1762. Indova gives a similar figure claiming 3 million people took part in Pugachevshchina. E. I. Indova, A. A. Preobrazhenskii and Iu. A. Tikhonov, "Narodnye Dvizhenie v Rossii 17-18 vv. i Absoliutizm" in Absoliutizm v Rossii, 17-18vv. Sbornik Statei, ed. Nikolai M. Druzhinin, (Moskva: Nauka, 1964), 77.

${ }^{2}$ E. I. Indova, A. A. Preobrazhenskii and Iu. A. Tikhonov, "Narodnye Dvizhenie v Rossii 17-18 vv. i Absoliutizm" in Absoliutizm v Rossii, 17-18 vv. Sbornik Statei, ed. Nikolai M. Druzhinin, (Moskva: Nauka, 1964), 77.

${ }^{3}$ There are various works about Cossacks that include Pugachev rebellion in several chapters. Some of them directly deal with Pugachevshchina like John T. Alexander, Emperor of the Cossacks: Pugachev and the Frontier Jacquerie of 1773-1775, (Lawrence, Kansas: Coronado Press, 1973); John T. Alexander, Autocratic Politics in a National Crisis; The Imperial Russian Government and Pugachev's Revolt, 1773-1775,(Bloomington: Indiana University Press, 1969); In Russian historiography the volume of works are enormous just a couple of them are as follows Vladimir V. Mavrodin, Krest'ianskaia Voina v Rossii v 1773-1775 Godakh: Vosstanie Pugacheva (Leningrad : Izdvo Leningradskogo Universiteta, 1961); A. I. Aksenov, R. V. Ovchinnikov and M. F. Prokhorov, comp., Dokumenty Stavki E. I. Pugacheva, Povstancheskikh Vlastei i Uchrezhdenii, 1773-1774 gg. (Moskva: Nauka, 1975); Iu. A. Limonov, Vladimir V. Mavrodin, V. M. Paneiakh, Pugachev i ego Spodvizhniki, (Leningrad: Nauka, 1965); I. G. Rozner, Kazachestvo v Krest'ianskoi Voine 1773-1775 gg. (L'vov: Izd-vo L'vovskogo Universiteta, 1966); S. S. Dreizen and E. I. Indova, Krest'ianskaia Voina 1773-1775 gg. v Rossii, (Vosstanie Pugacheva). Dokumenty iz Sobraniia Gos. Ist. Muzeia.(Moskva: Nauka, 1973); Iu. A. Limonov, Vladimir V. Mavrodin and V. M. Paneiakh, Pugachev i Pugachevtsy, (Leningrad: Nauka, 1974); Vladimir V. Mavrodin, Pod Znamenem Krest'ianskoi Voiny (Moskva: Mysl', 1974); R. V. Ovchinnikov, Sledstvie i Sud nad E. I. Pugachevym i ego Spodvizhnikami: Istochnikovedcheskoe Issledovanie, (Moskva: Rossiiskaia Akademiia Nauk, 1995); I. G. Rozner, Iaik pered Burei, (Moskva: Mysl', 1966); Kh. I. Muratov, Krest'ianskaia Voina 1773-1775 gg. v Rossii, (Moskva: Voennoe izd-vo
} 
the west and in Russia. First, most studies tended to focus on the history of the Cossacks or the Russian people in conflict-ridden areas, an approach which makes nationalities a marginal issue in the Pugachev rebellion. Second, Russian historians tended to take an imperialist perspective that viewed nationalities as small backward groups, lacking initiative and unimportant. Some Russian historians hold that the frontier peoples simply invited the Russians to take over to liberate them from the yoke of local nobility. The historians in the west largely remained ignorant of the issue and went along with the Russian literature. Accordingly they neglected, by and large, to study the alliance of the intruder and the native.

The cooperation between the intruder and the natives was a unique case in Russia. The frontiers in the modern period never witnessed such a case. Though it may seem a contradiction since the intruders and the natives were considered intractable enemies, the nature of the Russian frontier in Bashkiria was apt to produce such an outcome since most of the intruders were also victimized by the Russian government's centralizing policies. So the study of Pugachev from the standpoint of the nationalities and cooperation of different ethnicities is an important example of rebellion and collaboration by national groups in one of the largest popular rebellions in Russian history.

This chapter examines Pugachev rebellion from standpoint of Bashkirs and their relations with both Pugachev's rebels and Russian government forces. It shows that the Bashkirs still had some rebellious potential and that the Russian governments' policy of colonizing Bashkiria and subsequently eliminating Bashkir belligerence was still incomplete.

Ministerstva Oborony Soiuza SSR, 1954); N. V. Gorban', "Krest'ianstvo Zapadnoi Sibiri v Krest'ianskoi Voine 1773-1775 gg." Voprosy Istorii, 11(1952); Ia. K. Grot, Materialy dlia Istorii Pugachevskogo Bunta, Bumagi Kara $i$ Bibikova, (1862); N. F. Dubrovin, Pugachev i Ego Soobshchiki, Epizod iz Istorii Tsarstvovaniia Imperatritsy Ekateriny II 1773-1774 gg. Po Neizdannym Istochnikam, 3 volumes, (1884) 
Bashkirs supported Pugachev ambivalently. As happened in the past, some of them fully joined the rebellion, some vacillated and changed sides more than once, and a minority remained fiercely loyal to the Russian government. What began as one rebellion was divided into two after the capture of Pugachev in September 1774. Bashkirs probably joined Pugachev with ulterior motives and as the Pugachevshchina dissipated, a new rebellion of Bashkirs emerged from it. While from the Russian point of view the Pugachev rebellion was in the borderlands, from Bashkir standpoint Russians were still intruders. ${ }^{4}$

\section{Background: The Russian Government and the Urals Nationalities in the $18^{\text {th }}$ Century}

The Pugachev rebellion was in part a war of nations against a common enemy, the Russian state, considering the serious contributions of the non-Russian peoples of the Volga-Ural region. Aside from Russians nearly all the peoples of the Volga-Ural region became involved. Bashkirs, Tatars, Kalmyks, Mishars, Maris, Mordvins, Chuvashs, Udmurts, Kazakhs, and even German colonists had grudges the imperial policies of the Russian empire and Catherine the Great's enlightened reforms had come too late and offered too little. A glance at the situation in the Volga-Urals region illustrates the reasons why these people so willingly joined Pugachev's Cossack army. The Tatars of the Volga were oppressed during the term of the Office of the New Converts in the 1740s and the 1750s. Bashkirs and Kalmyks indignant over Catherine II's sedentarization and centralization policies willingly joined Cossack rebels. ${ }^{5}$ In a similar way the Russian engagement in the Kazakh lands had been strengthened by Catherine the Great which

\footnotetext{
${ }^{4}$ To his great dismay, the Bashkir rebel leader Salavat Iulaev realized that Bashkiria had been firmly surrounded by Russian fortification system when he attempted to flee to the Kazakh steppe and was prevented by the firmness of Russian defensive line.

${ }^{5}$ Michael Khodarkovsky, Where Two Worlds Met: The Russian State and the Kalmyk Nomads, 1600-1771, (Ithaca \& London: Cornell University Press, 1992), 140-141
} 
triggered Kazakhs participation in the Pugachevshina. ${ }^{6}$ These three largely nomadic groups, Bashkirs, Kalmyks and Kazakhs, suffered at different rates from the Russian government's policies destructive of the local nomadic economies. Although they were traditional enemies and rivals for the pasturelands, and their enmities had been skillfully exploited by the Russian authorities, with the emergence of an impostor they were too willing to fall for his generous promises and participate in the rebellion.

The hold of the Russian government in the frontier areas had increased during the eighteenth century. The foundation of Orenburg Gubernia in 1744 enabled the government to increase its control in these once free frontier areas. The rise in power of the Russian officials (chinovnik) was remarkable during the period from 1744 to the early 1770 s. This greatest frontier rebellion in the history of Imperial Russia also was a result of the success of Russian absolutism. This became possible with the strengthening of the Russian nobility throughout the imperial system partly due to the fears of Catherine II about another palace putsch that haunted Russian monarchs after Peter the Great. ${ }^{7}$ As part of this strengthening of imperial control in the frontier areas, all aspects of life came under greater control of the Russian officials. Their legendary arbitrariness and corruption antagonized not only non-Russian populations of the remote areas of the empire but also the loyal guardians of the Russian borders, the Cossacks, whose story falls beyond the scope of this essay but has been discussed in many previous studies.

By the 1770s the Russian authorities had not won all the Bashkirs' loyalties by distributing gifts, material benefits and rewards to all Bashkir nobles, and had only partially transformed the region's economy to a completely agricultural one. As long as Bashkirs

\footnotetext{
${ }^{6}$ Galina M. Yemelianova, Russia and Islam A Historical Survey, (New York: Palgrave, 2002), 57; Michael Khodarkovsky, Russia's Steppe Frontier; The Making of a Colonial Empire 1500-1800,(Bloomington: Indiana University Press, 2002), 174

${ }^{7}$ Perry Anderson, Lineages of Absolutism (London: Verso, 1979), 342
} 
remained nomadic to a certain degree the tensions would inevitably lead to the renewal of armed conflicts. As Marc Raeff maintains during the eighteenth century the Russian government attempted to sedentarize the Bashkirs, a policy which would bring supposedly their assimilation and Russification as well. If this policy had succeeded the Bashkir lands would have been more open to Russian colonization and Russian peasants would have migrated to the region without the fear of nomadic raids. ${ }^{8}$ The events that took place after September 1774 were the evidence of the limited effects of Tsarist policies in the region.

By this period disgruntled masses sought a way to solve the problems that the Russian state's policies had caused throughout the empire. In the early 1770s the Russian state was at war with the Ottoman Empire while absorbing large chunks of the Polish state after the first partition of 1772. The demands of wars were immense and the population was overwhelmed with taxes, recruitment, and other obligations to meet war requirements. For example, the War College ordered Cossacks to join the regular army, abandoning their traditional role in the imperial army as irregulars, and to shave their beards, a loathsome action for Cossacks who followed the traditional creed of the Old Believers. ${ }^{9}$ Mobilization for war required a strict draft system and over the five years 323,326 men had been drafted by the central authorities. ${ }^{10}$

\section{The Bashkirs and the Beginning of Pugachev's Rebellion}

While Cossacks under Pugachev began the rebellion, the Bashkirs soon played roles nearly equal to those of the Cossacks in leading it. The mainstream Soviet and western historiography call this war the last great peasant war by the Russians. Yet the Bashkirs were the

\footnotetext{
${ }^{8}$ Marc Raeff, "Pugachev's Rebellion" in Major Problems in the History of Imperial Russia, ed. James Cracraft, (Lexington: D. C. Heath and Company, 1994), 188

${ }^{9}$ John T. Alexander, Emperor of the Cossacks: Pugachev and the Frontier Jacquerie of 1773-1775, (Lawrence, Kansas: Coronado Press, 1973), 35

${ }^{10}$ Simon Dixon, Catherine the Great, (HarperCollins E-Books, 2001), 228
} 
most numerous national group on the side of rebels. Without them, the rebellion would have been doomed to remain just another Cossack bunt. Bashkirs provided horses, fodder, provisions to Pugachev's forces in Berda, some ten miles from Orenburg city, intercepted correspondence of the governmental forces and reported their whereabouts to the headquarters of Pugachev. Most important of all, the Bashkirs fought alongside Pugachev. ${ }^{11}$ They had gained experience against the Russian state in military fields during their numerous rebellions. No other non-Russian group had rebelled as often and with such a degree of success against the Russians as the Bashkirs. ${ }^{12}$ They also may have suffered more than any other group and consequently may have thought that they had the least to lose. Accordingly, a larger share of Bashkirs joined Pugachev's rebels than any other minority group including Pugachev's own Cossacks; only a minority of Cossacks fought against the government while the majority remained loyal. ${ }^{13}$ Accordingly the Pugachev Rebellion might also be considered as another Bashkir-Russian war. At what point did they unite their powers? The initiative, many sources maintain, came from Pugachev who was keen on extending the front against the government by winning the support of all nationalities in these regions from the Urals to the Middle Volga. The war mainly took place in Orenburg Gubernia during the early stage of the war and the peoples of Orenburg region with some minor exceptions sided with the rebels.

The rebellion began on 17 September 1773, when Pugachev dictated his first manifesto as tsar Peter III, promising land and freedom, amnesty for those who had taken part in the

\footnotetext{
${ }^{11}$ I. M. Gvozdikova, Salavat Iulaev, Issledovanie Dokumental'nykh Istochnikov (Ufa: Kitap, 1992), 148.

${ }^{12}$ The criterion for their success is the Russian state's timidity in imposing new and radical policies in Bashkiria. They had to think twice about the Bashkir reaction.

${ }^{13}$ A. G. Biishev, Istoriia Bashkirkogo Naroda i Ego Bor'ba za Svobodu, (Ufa: Kitap, 1993), 105 (In Bashkir). There are counter views by the Russian historians who considered Pugachevshchina mainly a Cossack rebellion against the state by minimizing other nationalities' contribution to the incident. S. G. Pushkarev, Obzor Russkoi Istorii (New York: Izdatel'stvo Imeni Chekhova, 1953), 340-341. Interestingly Pushkarev, a Soviet historian, calls Pugachevshchina a bunt (riot) rather than vosstanie (rebellion). On the other hand Dimitriev argues that Bashkir efforts on the side of Pugachev were considerable V. D. Dimitriev, Chuvashskie Istoricheskie Predaniia (Cheboksary: Chuvashskoe Knizhnoe Izd-vo, 1993), 316.
} 
previous rebellions, a definitely Bashkir-oriented promise, and freedom of religion again for the Muslim-Turkic peoples of the empire. The next day 20 or so Bashkir cavalrymen joined him. Within a few days the manifesto of Pugachev was translated into Bashkir language by Iderkai Baimekov, a Bashkir from the Iaik Cossack host with a modest social background. From the very beginning Iderkai played an instrumental role in attracting Bashkirs to the side of Pugachev. He was also responsible for writing letters to the Kazakh Khan Nur Ali to join Pugachev. ${ }^{14}$

\footnotetext{
${ }^{14}$ N. M. Kulbakhtin, "Iderkai Baimekov," in Bashkirskaia Entsiklopediia, ed. I. G. Akmanov and Aznagul Uruskulov, v. 3, (Ufa: Nauchnoe Izdatel'stvo, 2005), 132; for greater detail about this remarkable Bashkir see, I. G. Akmanov, ed., Istoriia Bashkortostana s Drevneishikh Vremen do Nashikh Dnei v Dvukh Tomakh, v. 1, (Ufa: Kitap, 2007), 225-226.
} 


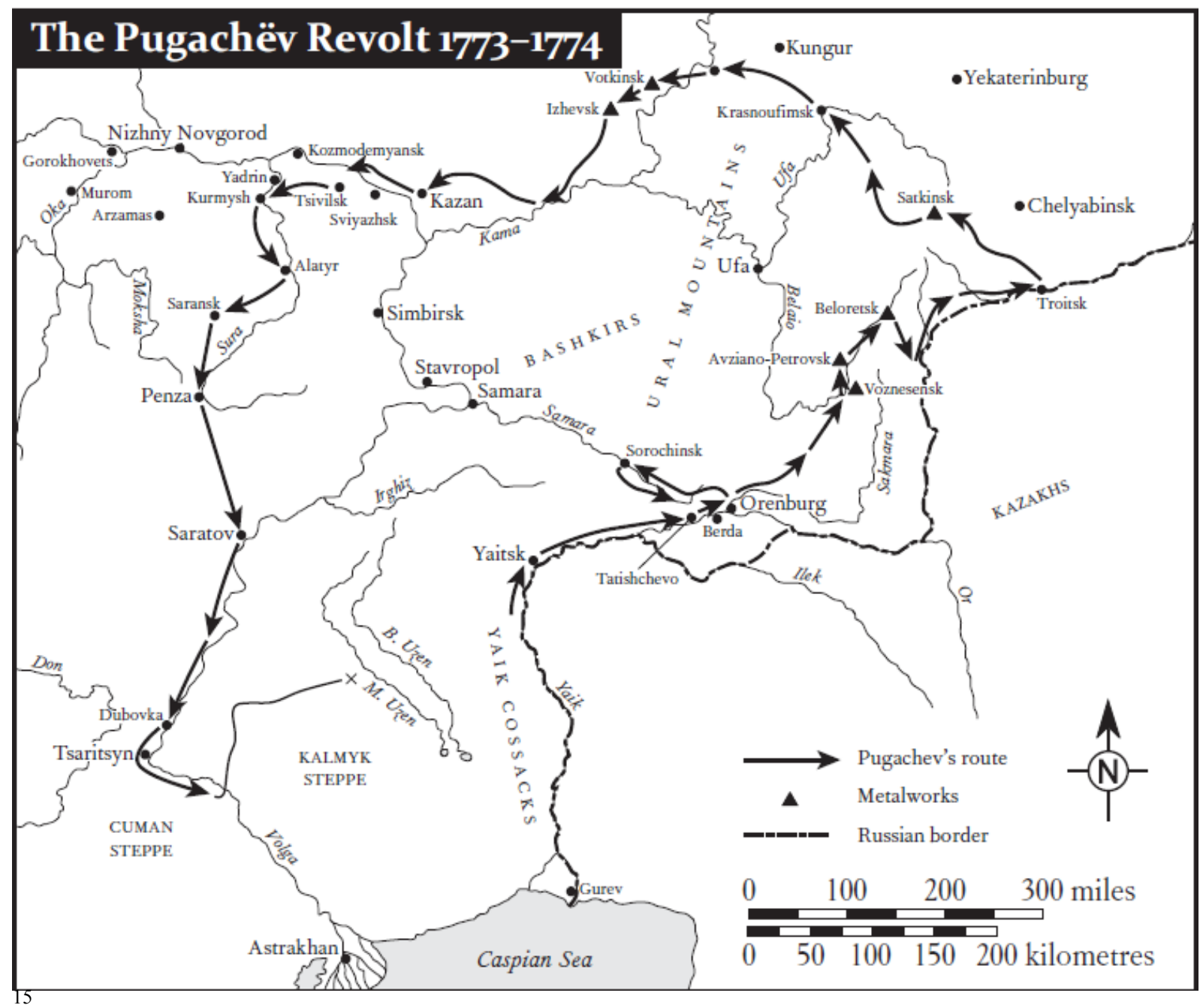

Posing himself as Tsar Peter III, who allegedly survived his ouster in 1762 by his wife Catherine, Pugachev promised to serve the Bashkirs as he did earlier and to treat them graciously and with compassion. He promised to restore the conditions that were set by Ivan the Terrible in 1552. He also assured to return their lands, fishing rights, fields, and forests. He would restore law and order in the region from which everybody would benefit. Religious freedom would be granted to all those who suffered under the yoke of the autocracy. Old believers, Pagans and Muslims would be all free to practice their religions. Those who had their lives based on the steppe would again enjoy their old privileges. They would again as free as stepnye zveri, steppe ${ }^{15}$ The source of the map is Simon Dixon, Catherine the Great, (HarperCollins e-books, 2001) 
animals. They would be as free as their grandfathers and their children and grandchildren would be as free as they, i.e. Bashkirs. ${ }^{16}$

In Pugachev's appeals, the Bashkirs found at last responses to their grievances about the land seizures by large factories and landlords (pomeshchiki), repressiveness of the local administrators and the overwhelming demands by the state, the most burdensome of which was military service. ${ }^{17}$ One other grievance of Bashkirs was the abolition of the Iasak payment system by the Russian government in 1754 and the imposition of the special tax on salt, which was free up to that time, by the government at a fixed price (35 Kopeks per pud ${ }^{18}$ ) on Bashkirs and Mishars. The revenues of the government from the salt tax exceeded those of Iasak payments and it was financially a more burdensome obligation on Bashkirs. To the Bashkirs this reform seemed to violate their historical privilege of Votchina rights. They concluded from this that, the government was attempting to deprive the Bashkirs of what they considered their earlier privileged status, demoting them to the level of other peoples in the region, a dramatic loss of status. ${ }^{19}$

Last but not least, the absolutist policies of Catherine II's reign caused another blow to Bashkir pride. Traditionally Bashkir starshinas were elected by their own people and since the starshinas were rich people, their election was fairly certain and the title of starshina could be inherited by their sons. The administration of Catherine II, however, abolished this method and decided to appoint Bashkir starshinas. Those who proved to be loyal, submissive, and docile

\footnotetext{
${ }^{16}$ R. B. Ovchinnikov, et.al., Dokumenty Stavki E. I. Pugacheva, Povstancheskikh Vlastei i Uchrezhdenii, 1773-1774 gg. (Moskva: Nauka, 1975), 27.

${ }^{17}$ Kh. F. Usmanov, ed. Istoriia Bashkortostana s Drevneishikh Vremen do 60-kh Godov 19 v. (Ufa: Kitap, 1997), 298.

${ }^{18} \mathrm{Pud}$ is equivalent of 36.11 pounds, (16.38 kilograms)

${ }^{19}$ V. Zabirov, "Novye Istochniki ob Uchastii Natsionalov v Pugachevshchina" Problemy Istochnikovedeniia, 1. (1933), 37; V. V. Mavrodin, ed., Krest'ianskaia Voina v Rossii v 1773-1775 godakh, Vosstanie Pugacheva, v. 2, (Leningrad: Izdatel'stvo Leningradskogo Universiteta, 1966), 140-142; I. M. Gvozdikova, Salavat Iulaev, Issledvoanie Dokumental'nykh Istochnikov, (Ufa: Kitap, 1992), 142; It must also born in mind that this salt tax issue was also one of the major reasons for the outbreak of the Batyrsha rebellion of 1755-1756.
} 
would be appointed by the local governors as the new leader of Bashkirs. However on the other hand these appointed starshinas were treated as lower ranking officials by the local administrators which represented a significant loss of status. So the government had alienated both the Bashkir people and likely supporters of the regime. ${ }^{20}$ After all, Pugachev's manifesto was a fresh hope for the Bashkirs to restore their former ways of living.

However, Pugachev had no clue about how to restore the former privileges of the Bashkirs since it was impossible to get rid of settlements created by Russians and other ethnic groups by the 1700 s, and it was impossible to reverse the conditions created by newcomers. At the time nobody paid any attention to the impossibility of the promises of Pugachev.

\section{The Bashkirs and Conflicts within Pugachev's Forces}

One of the main tenets of the Russian policy in the borderlands was to keep different groups separate from each other and prevent their fraternization. There are accounts that Russian authorities deliberately attempted to keep Russian settlers and indigenous people hostile to each other by telling Russian settlers that Bashkirs were not reliable in any way, and claiming that the Russian peasant must be on guard when they see Bashkirs who are nothing but horse thieves and robbers. $^{21}$

The Bashkirs' cooperation with Pugachev was a unique case in the history of frontier societies (European vs. indigenous peoples) where intruders and indigenous peoples joined to fight a common enemy. Usually by default intruders and indigenous peoples were natural opponents. In the American West, for example, Indians and White settlers never combined their forces to fight to overthrow the existing American political regime. In the Russian case, by

\footnotetext{
${ }^{20}$ I. M. Gvozdikova, Salavat Iulaev, Issledovanie Dokumental'nykh Istochnikov (Ufa: Kitap, 1992), 157.

${ }^{21}$ I. G. Akmanov, "Istoricheskie Predposylki Sovmestnoi Borby Bashkirskogo i Russkogo Narodov v Krest'ianskoi Voine 1773-1775 gg.” in Narody v Krest'ianskoi Voine 1773-1775 gg. ed. V. I. Buganov, (Ufa:1977), 56.
} 
contrast, the tsarist regime and its servitors or officials had managed to antagonize both the intruder and the native.

To win the support of the local people, Pugachev felt compelled to win a major military success to counteract government efforts to deter the Bashkirs from siding with the rebels. They were the most belligerent of all local groups and had a strong anti-Russian character in their life style and historical background. A post-Soviet Bashkir historian claimed that the majority of Bashkirs joined Pugachev's effort, ${ }^{22}$ but he fails to provide reliable evidence. A Soviet publication of 1957 on the other hand claimed that laboring masses of Russians and other nationalities time and again united against the oppressive and exploitative tsarist system. ${ }^{23}$ Such an argument was natural because in the 1950s predominant theme in Soviet history writing was the friendship of peoples. ${ }^{24}$ This Soviet saga of "friendship of nationalities" was told in similar lines repeating the same themes stating that none of the previous class wars that took place in the Russian empire had such a nature of comradeship of Russian laboring masses and Bashkir toiling peoples against the central authority and feudal lords in the provinces. ${ }^{25}$

Economic changes also support this interpretation. The economic gap between two groups was closing during the eighteenth century thanks to the accelerated rate of the sedentarization of Bashkirs. I. G. Akmanov, a prominent Bashkir historian, argues that after two hundred years of Russo-Bashkir relations at grassroots level, Bashkirs quite naturally had turned

\footnotetext{
${ }^{22}$ Zufar Enikeev, Pravovoi Status Bashkortostana v Sostave Rossii, Istoriko-Pravovoe Issledovanie (Ufa: Gilem, 2002), 82.

${ }^{23}$ Lowell Tillett, The Great Friendship: Soviet Historians on the non-Russian Nationalities, (Chapel Hill: University of North Carolina Press, 1969), 285-286; Post-Soviet regional historians still adhere to this notion and regard Pugachev Rebellion as one of the class wars which was led by a united front of nationalities against the government's repressiveness and exploitation. For these authors, ethnic social or religious differences were suspended and they combined their efforts against the government. Kh. F. Usmanov, ed. Istoriia Bashkortostana s Drevneishikh Vremen do 60-kh Godov 19 v. (Ufa: Kitap, 1997), 294.

${ }^{24}$ Lowell Tillett, The Great Friendship: Soviet Historians on the Non-Russian Nationalities, (Chapel Hill: The University of North Carolina Press, 1969), 4

${ }^{25}$ M. A. Rakhmatullin, "Krest'ianskaia Voina v Rossii 1773-1775 Godov" Istoriia SSSR, 6 (1973), 45; V. N. Eliseeva, Kratkii Ocherk Istorii Cheliabinskoi Oblasti, (Cheliabinsk: Iuzhno-Ural'skoe Izd., 1965), 80.
} 
out to be seriously affected by the Russian and other settlers and learned quite a lot from them, buying their agricultural tools and learning their habits and accordingly ipso facto passed to the stage of sedentarization. When the war broke out against the Russian government it was unavoidable for both groups to form an alliance against their common oppressor; the tsarist regime. $^{26}$

While the Bashkirs' cooperation with Pugachev was relatively unique, however, the links between them should not be overestimated or exaggerated. The Bashkir and Cossack alliance was partly an alliance of convenience, and throughout the war their relations remained tense. Since the conditions which had caused so many wars, especially land seizures by the intruders, did not cease to exist, a base for a permanent alliance between Russian peasants or Cossacks and Bashkirs seemed impossible. Also the religious and cultural barriers remained the same and the land seizures had already created hostilities. While Bashkirs needed allies to regain their former client status and Cossacks needed fighters against the central authority, these two groups radically differed from each other. Bashkirs were Muslims, Cossacks were devout Christians. Bashkirs were steppe peoples, while Cossacks were the ones who delimited Bashkir movements in the steppe region. Bashkirs were nomads; Cossacks were sedentary. Bashkirs were very often rebellious; Cossacks were most of the time loyal and fought against Bashkirs. The real details of their cooperation remain obscure to the historians; only from a general perspective there are rooms for speculation available. The existing archival documents hint that the centralizing policies of the Russian government drove these two indomitable rivals toward each other. This was a fatal combination which the Russian authorities feared most.

\footnotetext{
${ }^{26}$. G. Akmanov, "Istoricheskie Predposylki Sovmestnoi Borby Bashkirskogo i Russkogo Narodov v Krest'ianskoi Voine 1773-1775 gg.” in Narody v Krest'ianskoi Voine 1773-1775 gg. ed. V. I. Buganov, (Ufa:1977), 51.
} 
These two different groups and their different life styles and world views could barely get along with each other. The tensions had always existed and would continue to exist due to the fact that Bashkirs had difficulties to adjust themselves to the socio-economic conditions created by newcomers. Even those seemingly submissive Bashkir groups had grudges against the government and settlers who grabbed their lands and reduced them to mere beggars of favors. It was very unlikely that the cooperation between Bashkirs and rebellious Russian peasants under Pugachev's command could last longer than the rebellion.

The Russian government had managed to form a large Bashkir armed force, numbering perhaps twelve thousand cavalrymen, against Pugachev during the initial stages of the war. ${ }^{27}$ Yet the rebellious Bashkirs managed to bring together under Pugachev almost the same number of Bashkir cavalrymen by Kinzia Arslanov. ${ }^{28}$ Both the government and Pugachev were racing against time to win the support of the Bashkirs. According to other evidence, however, Russian authorities somehow were sure of the loyalty of the Bashkirs against Pugachev, probably considering the Cossacks' Russian-Orthodox nature under Pugachev. The military governor of Orenburg, I. A. Reinsdorp, assumed that the Pugachev rebellion was just another Iaik Cossack "riot". He was so sure of the loyalty of Bashkirs that when the rebels appeared before the walls of Orenburg he did not hesitate to send a Mishar-Bashkir brigade of 500 troops to crush the

\footnotetext{
${ }^{27}$ I. G. Akmanov, ed., Istoriia Bashkortostana s Drevneishikh Vremen do Nashikh Dnei v Dvukh Tomakh v. 1, (Ufa: Kitap, 2007), 231.

${ }^{28}$ I. M. Gvozdikova, Bashkortostan Nakanune i v Gody Krest'ianskoi Voiny Pod Predvaditelskom Pugacheva, (Ufa: Kitap, 1999), 280-281.; Kinzia Arslanov was from Nogai Doroga and he was a noble of Bushman-Kypchakskoi Volost, a starshina and also an abyz. N. M. Kulbakhtin, "Kinzia Asrlanov" in Bashkirskaia Entsiklopediia, v. 3, ed. I. G. Akmanov and Aznagul Uruskulov, (Ufa: Nauchnoe Izdatel'stvo, 2005), 401; Quite naturally thanks to his social background he had greater chances to persuade Bashkir masses to join the rebellion than Iderkai Baimekov who was reduced into a much diminished position in the entourage of Pugachev. Kinzia was appointed colonel major of the Pugachev's main force and he provided a vital link between Pugachev and indigenous people. A. N. Usmanov, "Kinzia Arslanov, Vydaiushchiisia Spodvizhnik Pugacheva" Istoricheskie Zapiski, 71, (1962), 113-131.
} 
rebels. The same wishful thinking about Bashkir loyalty in suppressing rebellion was shared by Catherine II. $^{29}$

One of the most formidable tasks of the rebellious camp of Pugachev was to provide some semblance of government and put an effective resistance to the excesses of the rebellious military groups against the civilians, whose support for their cause was vital. From the very beginning Pugachev's leadership faced the deep crisis of interethnic conflict among the rebellion's many supporters. The leadership received numerous complaints about the Bashkir or Mishar troops' excesses against the Russian settlements. So they decided to defend the Russian villages near Ufa against the attacks of Bashkirs and Mishars. ${ }^{30}$

Despite these troubles of providing balance between his goals and keeping non-Russians within his camp, Pugachev did something remarkable that had a transforming effect at least for the Bashkirs. As noted above in relation to the Bashkirs, Pugachev also sent such nativelanguage documents to Tatars, Mishars and Kazakhs. For the first time these peoples received an official document from the highest authority of the empire in their own languages. In these documents Pugachev repeatedly guaranteed their religious, social, economic and cultural rights. ${ }^{31}$ Without doubt these factors played a determining role in the emergence of ethnic consciousness among these peoples. Of course, to come together they did not need anything in their own language. Any strong leadership promising what they wanted could unite these people. Still, the publication of pamphlets in indigenous languages in Pugachev's camp indicated that many members of these national groups sided with Pugachev and served as his emissaries among the native peoples of the region.

\footnotetext{
${ }^{29}$ D. Anuchin, "Pervye Uspekhi Pugacheva i Ekspeditsiia Kara" in Voennyi Sbornik, 6 (1869), 179.

${ }^{30}$ I. M. Gvozdikova, Bashkortostan Nakanune i v Gody Krest'ianskoi Voiny Pod Predvaditelskom Pugacheva, (Ufa: Kitap, 1999), 293.

${ }^{31}$ I. M. Gvozdikova, Bashkortostan Nakanune i v Gody Krest'ianskoi Voiny Pod Predvaditelskom Pugacheva, (Ufa: Kitap, 1999), 301-302.
} 
It can be argued that the results of the policy of recognizing Bashkir identity and a return to the old system was extremely successful despite government's attempts to prevent this. As a result some 50,000 Bashkir directly took part on Pugachev's side. The interesting point is that nearly all starshina groups of Bashkirs in Ufa and Isetsk provinces, formerly pro-government groups against rebellious Bashkir in the past, sided with Pugachev. While no evidence that I have seen about Bashkirs' attitudes in the documents is available, it is possible that they were either overwhelmed or disappointed by the Russian policies in the region. They might also have believed that they were fighting on the side of a deposed Russian tsar who represented the real Russian power, not a usurper and a woman, Catherine II. Last but not least, these starshinas' powers over their people had limits as had been stressed in the previous chapters. If their people chose to side with the rebels, starshinas had no other option but to join them.

\section{The Bashkirs between the Russian Government and Pugachev}

The native groups did not form a monolithic front during the Pugachevshchina. Some groups of Bashkirs effectively evaded officials' orders to join the governmental forces. When in October of 1773, the governor of Orenburg, Reinsdorp, ordered the formation of a detachment of 5000 Bashkirs in Ufa Uezd, Bashkirs were in no hurry to join the punitive forces of the government at this stage while the dice had just been cast. ${ }^{32}$ At the same time Cossacks and Bashkirs distrusted one another. Since Bashkirs had an anti-Russian attitude it was difficult to form a coalition against the Russian government and its local agents in the region.

However the early defeat of the Russian general V. A. Kar by the forces of Pugachev on November $9^{\text {th }}$ and his adjutant general P. M. Chernishev on November $13^{\text {th }}, 1773$ created the

\footnotetext{
${ }^{32}$ R. G. Kuzeev and R. V. Ovchinnikov, comp., Krest'ianskaia Voina 1773-1775 gg na Territorii Bashkirii, Sbornik Dokumentov, (Ufa: Bashkirskoe Knizhnoe Izdatel'stvo, 1975), 36.
} 
necessary backdrop for the Bashkirs to abandon their hesitations about the future of the conflict. ${ }^{33}$ The initial underestimation of the government about the size of the conflict and their constant efforts to neutralize non-Russian peoples of the region brought them to the camp of the rebels thanks to these two shocking rebel victories.

The government's efforts to crush the rebellion at such an early stage were dashed due to its misinterpretation of the allegiances of seemingly loyal Bashkirs. At this time nearly half of the punitive forces were composed of Bashkirs. The government was arming them and ordering them to the front against the rebels, but these units began deserting to join the rebels en mass with their precious guns, so the government was indirectly helping rebels gain strength. On November 20, at least 1200 Bashkir cavalry units under Alibai Murzagulov from Nogai Doroga took their guns and left the government forces to join the rebels. At the end of November, 1236 Bashkir and Mishar soldiers under the command of General Major F. Iu. Freiman deserted and went to the rebellious camp. A few weeks later they were joined by 726 Bashkir soldiers who had just returned from the Polish front. On December 7, the voevod of Isetsk province, A. P. Berevkin, sent his report to the Imperial Senate emphasizing the situation that Bashkir-Mishar troops were joining the rebel camp as soon as they were recruited. ${ }^{34}$

Surprisingly this time Bashkirs and their former enemies Isachnye Tatars and Mishars ended up in the same camp, in much the same way as Bashkirs cooperated with the Cossacks. By December 1773, all four dorogas of Bashkiria (Kazan, Nogai, Sibir, Osin) were in disarray and these peoples including Iasak-paying Cheremis were not indifferent to the Pugachev

\footnotetext{
${ }^{33}$ The defeat of Kar became possible thanks to Bashkirs' scuffing to rush to the help of Kar whose forces were fighting against Pugachev's forces at a spot not far away from the encampment of the Bashkir forces who were technically serving the state at the time. I. M. Gvozdikova, Salavat Iulaev, Issledovanie Dokumental'nykh Istochnikov, (Ufa: Kitap, 1992), 146.

${ }^{34}$ Kh. F. Usmanov, ed., Istoriia Bashkortostana s Drevneishchikh Vremen do 60-kh Godov 19 v., (Ufa: Kitap, 1997), 299.
} 
rebellion. The accounts by the local Russian officials reveal the fact that most Bashkirs had joined Pugachev's camp in December of 1773 only a few months after the outbreak of the war. A report dated 30 December 1773 by the Senate to general Aleksandr I. Bibikov (1729-1774), who played a very active role in the defeat of the rebellion later on, noted that the majority of the Bashkir people, believing the promises of Pugachev were genuine, joined his camp and their numbers were rising fast. ${ }^{35}$ Orenburg governor Ivan A. Reinsdorp (1730-1781) reports that at least five thousand Bashkirs were available in the camp of rebels besieging the town. This number was several times larger than the number of Cossacks of the same group. ${ }^{36}$

In the same context, independent of Pugachev's directives, some Bashkir armed groups acted on their own volition and attacked Russian defensive positions, with some cooperation from Pugachev's forces, of course. The most important leader of these independent Bashkir forces was Kaskin Samarov. He was formerly a loyal Bashkir who had competently served in the Russian military expedition against Poland from 1771 to 1773 . Upon his return to Bashkiria, he himself embarked upon gathering forces. He managed to attract to his side the 400 battlehardened Bashkir troops returning from the Polish front and took part in storming Ufa with Pugachev's lieutenant I. N. Zarubin. He was more interested in attacking Russian settlements but in March 1774 when the siege of Ufa was defeated, he submitted to I. I. Mikhelson, a Tsarist colonel who played the determining role in crushing the Pugachevshchina militarily. Yet Samarov again joined the rebel camp in the May of the same year.

\footnotetext{
${ }^{35}$ V. M. Paneiakh, “O Stepeni Uchastiia Narodnostei Bashkirii v Krest'ianskom Voine 1773-1775 gg. na Pervom ee Etape" in Uchenie Zapiski Permskogo Universiteta, 158, (Perm, 1966), 51-52.

${ }^{36}$ V. M. Paneiakh, "O Stepeni Uchastiia Narodnostei Bashkirii v Krest'ianskom Voine 1773-1775 gg. na Pervom ee Etape" in Uchenie Zapiski Permskogo Universiteta, 158, (Perm, 1966), 52. This number was at least two times bigger than that of mid October. See Kh. F. Usmanov, ed. Istoriia Bashkortostana s Drevneishikh Vremen do 60-kh Godov 19 v. (Ufa: Kitap, 1997), 233.
} 
Samarov was a typical native frontier warrior. Such figures when overwhelmed submitted but when they found opportunity again rebelled. Interestingly the Russian authorities recognized the influential positions of such figures among the natives and never treated them sternly during the war, but when they believed they were of no use any longer they exterminated such leaders. Samarov again finally submitted to the authorities in February 1775. He was taken to Kazan where he was interrogated by the Kazan Secret commission. His ultimate fate is not known. $^{37}$

During the initial stage of the rebellion which lasted from September 1773 to January 1774, the whole of Bashkiria was under the impact of the war and nearly all Bashkirs had sided with the rebels. In terms of the land occupied by rebels it was the widest stage. While half of the participants were either Cossacks or Russian peasants, more than one third were Bashkirs and the rest came from other non-Russian groups whose participation made the event a more widespread one. If the Cossacks had been the only group of insurgents most probably the rebellion would have remained an extremely localized one and been easily crushed. ${ }^{38}$

For the first time since the outbreak of first massive Russo-Bashkir war in 1662, most Bashkir starshinas joined the rebellious group during the first stage of the Pugachev rebellion. While 77 starshinas of Ufa province took up arms against the government only 9 Bashkir starshinas preferred to stay on the side of the government. ${ }^{39}$ On an ethnically more varied context of 126 starshinas of Bashkirs, Mishars and Iasak paying Tatars of Ufa province, 114 of them (77

\footnotetext{
${ }^{37}$ I. G. Ilishev, ed., Salavat Iulaev, Entsiklopediia, (Ufa: Nauchnoe Izdatel'stvo, 2004), 161-162; Kh. F. Usmanov, ed. Istoriia Bashkortostana s Drevneishikh Vremen do 60-kh Godov 19 v. (Ufa: Kitap, 1997), 235;

${ }^{38}$ I. G. Akmanov, ed., Istoriia Bashkortostana s Drevneisikh Vremen do Nashikh Dnei v Dvukh Tomakh, v. 1, (Ufa: Kitap, 2007), 242.

${ }^{39}$ Iu. A. Limonov, V. V. Mavrodin, V. M. Paneiakh, Pugachev i Pugachevtsy, (Leningrad: Nauka, 1974$), 152$.
} 
Bashkirs, 37 Mishars and others) were on the rebellious side while only 12 of them remained loyal to the government. ${ }^{40}$

\begin{tabular}{|c|c|c|c|c|c|c|}
\hline & Starshinas & & & & & \\
\hline & Ethnicity & $\begin{array}{c}\text { Those } \\
\text { who } \\
\text { supported } \\
\text { rebellion }\end{array}$ & $\begin{array}{l}\text { Those } \\
\text { who } \\
\text { remained } \\
\text { loyal to } \\
\text { the state }\end{array}$ & $\begin{array}{l}\text { Those } \\
\text { who } \\
\text { switched } \\
\text { sides }\end{array}$ & $\begin{array}{l}\text { Those } \\
\text { whose } \\
\text { choices } \\
\text { are not } \\
\text { known }\end{array}$ & Total \\
\hline 1 & Bashkir & 158 & 13 & 11 & 10 & 192 \\
\hline 2 & Tatar & 26 & 8 & 5 & 3 & 42 \\
\hline 3 & Mishar & 5 & 20 & 3 & - & 28 \\
\hline 4 & Mari & 8 & 1 & - & - & 9 \\
\hline 5 & Udmurt & 2 & - & - & 1 & 3 \\
\hline 6 & Unknown nationality & 1 & 2 & - & 3 & 6 \\
\hline 7 & Total & 200 & 47 & 16 & 17 & $280^{41}$ \\
\hline
\end{tabular}

A starshina in a Bashkir community had the determining role in influencing the decisions of the Bashkir masses. So when a starshina decided to fight against the government the rest of

${ }^{40}$ I. G. Akmanov, ed., Istoriia Bashkortostana s Drevneisikh Vremen do Nashikh Dnei v Dvukh Tomakh v. 1, (Ufa: Kitap, 2007), 242.

${ }^{41}$ Salavat Taimasov, Vosstanie v Bashkortostane 1773-1775 gg., (Ufa: Kitap, 2000), 182. 
his community would be compelled to do so. However it must be born in mind that everything in the steppe frontier was fluid including loyalties of the people. The nearly universal uprising of Bashkirs in this war may be misleading because loyalties constantly shifted as we saw above in the case of Kaskin Samarov. This is what the Soviet / Post-Soviet historians failed to emphasize. They assumed that if a group chose one side at the beginning of the war they would by default remain in the same camp until the end of the war. Kaskin Samarov's case is also a genuine example of the application of the new imperial history. How the Russian authorities were relatively tolerant of these Bashkirs who changed sides, and the divisions within the ranks of the different national groups can be evidence that the imperial Russian history was more complex than simply crude oppression by the Russian authorities.

There were three types of Bashkir leadership during this war. The first group started as rebels and ended as rebels. Their numbers, while not large, were sufficient to provide leadership to numerous Bashkir groups. Kinzia Arslanov was the most distinguished of this group, which included Kutlugil'dy Abdrakhmanov, Karanai Muratov, and Iulai Aznalin and his famous son Salavat Iulaev, who is the most popular Bashkir historical hero and a national poet. The second group was not as large as the first one. Its members remained loyal to the government from the beginning to the end. A few of them were Iusup Nadyrov, Ziubair Iusupov, and Sagit Baltasev. Even though they were few, the rewards for their loyalty would be great at the end of the war. The last group was the largest one: Bashkirs who shifted their loyalties whenever conditions or their interests required it. The great majority of them began in the camp of Pugachev, receiving titles, grants and generous gifts from him. When the tide turned toward the government they all abandoned their initial camp and submitted to the government and actively took part in the 
suppression of the rebellion. ${ }^{42}$ These leaders' shifting allegiances reflected less opportunism than the dynamics of Bashkir society. In many cases these leaders had to face the criticism and insubordination of their tribes. When the tribe chose to fight against the government these leaders also had to go along with them.

When we have a closer look on the first group, the great majority of them were from the southern (Nogai Doroga) and eastern (Sibir Doroga) parts of Bashkiria which means these parts of the region were more nomadic and least amenable to the incursions of the settlers. So they were the ones who most rabidly resisted colonization of their lands and transformation of their nomadic life toward a more settled one.

Below is a limited list of Bashkir rebellious leaders and their origin. ${ }^{43}$

$\begin{array}{ll}\text { Abdulzialil' Uruskulov } & \text { Sibir Doroga } \\ \text { Bazargul Iunaev } & \text { Sibir Doroga } \\ \text { Il'chigul Itkulov } & \text { Sibir Doroga } \\ \text { Iulai Aznalin } & \text { Sibir Doroga } \\ \text { Iulaman Kushaev } & \text { Sibir Doroga } \\ \text { Karanaev Muratov } & \text { Nogai Doroga } \\ \text { Kaskin Samarov } & \text { Nogai Doroga }\end{array}$

\footnotetext{
${ }^{42}$ I. G. Akmanov, ed., Istoriia Bashkortostana s Drevneishikh Vremen do Nashikh Dnei v Dvukh Tomakh, v. 1, (Ufa: Kitap, 2007), 242. The authors gave a number of other leaders names but their situation was contradictory for example Kaskin Samarov was included in the first group but he is a more complex personality than was portrayed and he several times submitted to the government, So he cannot be mentioned as one of them who fought against the government until the very end remaining in the same group. For his biography and many other leaders of the period in Bashkiria. I. G. Ilishev, ed., Salavat Iulaev, Entsiklopediia, (Ufa: Nauchnoe Izdatel'stvo, 2004); The authors of Istoriia Bashkordostana are also mistaken about the ethnicity of Iusup Nadyrov who was presented as a Bashkir Starshina. However there is strong evidence that he was a Tatar Service man. See; Materialy po Istorii Bashkirskoi ASSR, v. 4, Part 1: Ekonomicheskie Sotsialnye Otnosheniia v Bashkirii i Upravlenie Orenburgskim Kraem v 50-7-kh Godakh 18 v., (Moskva: Izdatel'stvo Akademii Nauk, 1956), 453.

${ }^{43}$ The list is formed thorough the scanning of a number of encyclopedias relating to Bashkiria. I. G. Akmanov and Aznagul Uruskulov, ed, Bashkirskaia Entsiklopediia, v. 1, (First four volumes) (Ufa: Nauchnoe Izdatel'stvo, 2005); R. Z. Shakurov, ed., Bashkortostan: Kratkaia Entsiklopediia, (Ufa: Nauchnoe Izdatel'stvo, 1996); I. G. Ilishev, ed., Salavat Iulaev, Entsiklopediia, (Ufa: Nauchnoe Izdatel'stvo, 2004)
} 


$\begin{array}{ll}\text { Kinzia Arslanov } & \text { Nogai Doroga } \\ \text { Kutlugil'da Abdrakhmanov } & \text { Nogai Doroga } \\ \text { Salavat Iulaev } & \text { Sibir Doroga } \\ \text { Sliausin Kinzin } & \text { Nogai Doroga }\end{array}$

Those who took part in the suppression of the rebellion were generally from the western and northern parts of Bashkiria where Russian control was older and deeper and the sedentarization level was higher. There were also other non-Russian loyal groups who had settled as service people in the southern and eastern Bashkiria and these groups had no desire to lose the privileges that the Russian government granted them. The success of the rebels would have been their death verdict. Not surprisingly these loyal groups were again mostly nonBashkir Turkic groups of Mishars and Tatars. One of their leaders was Ziamgur Abdusalimov, a Mishar noble from Osin Doroga who had been granted land and settled in 1765-76 in Nogai Doroga where many rebellious Bashkir leaders originated. He and his elder brother Mustafin Abdusalimov were the ones who chased and captured Salavat Iulaev and his companions and delivered them to the Russian authorities for interrogation and thereby served their Russian masters in the way they were expected to. ${ }^{45}$ These brothers were certainly not alone in their services.

The Russian government's treatment of these loyal service people was quite generous: they were granted lands and presented titles and various other gifts. Another Mishar leader, Ishmukhamet Suleimanov and his brother Kil'mukhamet from Duvan Tabynsk district of Nogai

\footnotetext{
${ }^{44}$ To form an exact list of the rebellious Bashkir leaders of the Pugachev war is a very elusive subject for two reasons. First of all such a list can be formed with through search of RGADA, RGVIA or other archival materials each of which is composed of some 800 volumes with thousands of sections. The other reason is very swiftly changing loyalties of the leaders which none of the archival, materials could determine with exact precision. ${ }^{45}$ I. M. Gvozdikova, "Novye Dokumenty ob Areste Salavata Iulaeva” in Istoriia SSSR, 5. (1978), 146.
} 
Doroga settled in Urshak-Minskoi district of Nogai Doroga. They served leading a battalion of 1000 in the Sibir Doroga for frontier service. As a reward for their loyal services during the Pugachev rebellion they were invited to St. Petersburg and presented saber, sword, silver medal, 60 Rubles and expensive clothes. ${ }^{46}$

The rebel Bashkirs were divided among themselves about the ultimate goals of the rebellion, and the determination to resist Russian policies that harmed Bashkir economy varied among the Bashkir leaders. While some of them were inflexible and unbending opponents of the Russian regime, some others were all too willing to quit resistance in the face of concessions from the government. Such factors enabled the Russian authorities to divide them at an increasing pace as the military failures of the rebels became increasingly apparent. Even though the countryside in Orenburg Gubernia was under the control of the rebels, the major towns in the region were still controlled by the state forces. Ufa, Kungur, Orenburg, Menzelinsk were all controlled by the state and especially the lingering siege of Orenburg was tying a significant rebel force in a single spot when they were desperately needed against the actual fighting force of the government. These failures created hesitations about the end of the endeavor which paved the way for switching sides among starshinas, either Tatar, Mishar or Bashkir. Bibikov, the Russian commander in the region, wrote to Catherine II in February 1774 that the defeat of the villains everywhere had begun and those who less ambitiously joined Pugachev submitted to the authorities asking for forgiveness. ${ }^{47}$

So state forces and Pugachev were both tightrope walkers and the one who won military successes could undermine the other because of the constantly shifting loyalties of peoples in the region. With the defeats of the main rebel army in the early months of 1774 , the tempo of the

\footnotetext{
${ }^{46}$ Salavat Taimasov, Vosstanie v Bashkortostane 1773-1775 gg., (Ufa: Kitap, 2000), 250-251.

${ }^{47}$ Ia. K. Grot, Materialy dlia Istorii Pugachevskogo Bunta, Bumagi Kara i Bibikova, (Sankt Petersburg: 1862), 5758
} 
rebellion slowed down and the first desertions started to take place among the Bashkir rebels. One of the prominent Bashkir leaders, Iamansary Iaparov, not only left the Pugachev movement but also joined the punitive forces against Pugachev and other fellow Bashkir leaders. By midApril 1774, when it was still far from clear that Pugachev would be defeated, 37 Bashkir, Tatar and Mishar starshinas abandoned the rebellious movement and joined the punitive forces.

The factors that led to desertions from the Pugachev camp and the reasons for divisions among Bashkirs were difficult to determine but at least it can be maintained that by the 1770 s Bashkir society had undergone a considerable transformation and it was more stratified than it had been in the seventeenth century. The dynamics of Bashkir society were changing toward a more sedentary mode of life. While much work remains to be done on a historical and sociological analysis, it is possible to gain insight into these divisions through comparing two Bashkir leaders - Kulyi Baltachev and Iulai Aznalin, father of the famed Salavat Iulaev. Baltachev and Aznalin were of the same nationality, Bashkir, the same faith, Islam, and the same socio-political background, starshina. They were both from the same region in Bashkiria, Sibir Doroga. They were of approximately the same age: both of them were born either in late $1720 \mathrm{~s}$ or early 1730 s. Finally they had the same career in the service of the Russian state until the outbreak of rebellion in 1773. Both had fought in Poland in January 1772 and both of them before the Pugachev rebellion served in patrolling along the Orenburg defensive line. ${ }^{48}$

Despite such similarities in their backgrounds, they ended up joining different camps during the Pugachev rebellion. While Baltachev never lost his confidence in the Russian state's military capabilities, Aznalin became a significant leader of the rebellious Bashkirs. Baltachev

\footnotetext{
${ }^{48}$ For the short biographies of Baltachev and Aznalin see I. G. Ilishev, ed., Salavat Iulaev, Entsiklopediia, (Ufa: Nauchnoe Izdatel'stvo, 2004), 176-177 and 410-412; See also for the comparison of these two leaders the article of Bagumanov whose argument leads nowhere. Asylguzha Bagumanov, "Salavat Iulaev i Grazhdanskaia Voina 17731775 godov" Vatandash, 6, (1998)
} 
successfully defended Ufa and then Angasiaksk factory against the rebels, contested them on several occasions near Birsk and took part in the repression of Pugachev's supporters. ${ }^{49}$ It is not clear what factors really determined their different decisions. ${ }^{50}$ Possibly not all Bashkir leaders benefited from Russian rule at the same level. Some, unlike the other Bashkir leaders, were victimized. Baltachev's and Aznalin's different political choices were typical examples of the chronic disunity of Bashkirs. It is also a significant reason why they could never achieve any fundamental success like independence from Russian authority.

The Bashkirs had some chance to win this war, because the Russian government was also fighting a protracted and increasingly exhausting war against the Ottoman Empire, and the Bashkirs had found a valuable ally, Cossacks and other Russian settlers. Pugachev's rebellion could have pushed the government to redress at least some of their grievances. Despite these suitable factors, Bashkirs failed to unite as happened in the previous rebellions. While the explanation for this failure is complex, my evidence indicates that several factors were particularly important. While differential levels of economic progress among various Bashkir groups played a divisive role within the Bashkir society, the economic might of the Russian government which offered varying degrees of economic benefits to those Bashkirs who served the state partially led to these divisions. Traditional nomadic structures were also important. The still predominant tribal loyalties prevented the development of a full-fledged national identity and the rebels failed to devise a future for the tribal leaders who were satisfied with their

\footnotetext{
${ }^{49}$ I. M. Gvozdikova, Salavat Iulaev: Issledovanie Dokumental'nykh Istochnikov, (Ufa: Kitap, 1992), 46-50

${ }^{50}$ Sources indicate that Kulyi Baltachev was one of the richest Bashkir leaders who mostly benefited from his services to the Russian state and generously awarded by the authorities. See Materialy po Istorii Bashkirskoi ASSR Tom 5 pp. 552-554; I. M. Gvozdikova, Salavat Iulaev, Issledovanie Dokumental'nykh Istochnikov, (Ufa: Kitap, 1992), 46.; During the Polish campaign while Baltachev was awarded with a saber with silver ornaments, Iulai Aznalin was awarded with insignificant rewards and in the 1760s, he had fiercely protested the distribution of Bashkir lands of his volost to Russian entrepreneurs Ia. B. Tverdyshev and I. S. Miasnikov for the construction of Simskii Factory. He was fined 600 rubles, a vast sum of money, which may definitiely have played a role in his alienation with the Russian rule. See I. M. Gvozdikova, Salavat Iulaev, Issledovanie Dokumental'nykh Istochnikov, (Ufa: Kitap, 1992), 411.
} 
own scrappy leadership subservient to the Russian state. Many Bashkir leaders saw no future in an independent Bashkir state and in fact many of them had no reason to join to such an adventure. Militarily Bashkirs suffered from lack of equipment, supplies, soldiers and organization which necessitated a successful military struggle against a modern army.

The starshinas who remained loyal to the Russian state knew full well that the Russian army was a formidable fighting force. They were realistic and not willing to take risks and knew well where their advantages lay. ${ }^{51}$ The Russian state had obligated non-Russian nationalities to serve in the Russian imperial army and Baltachev and many other loyal Bashkir leaders had taken part in one or another military expedition of the imperial army. In comparing imperial forces and the Pugachev's ragtag army they saw no chances of success in a rebellion.

Their hesitations had gained support from the results of the battles. The rebels captured none of the major Russian garrison towns in Bashkiria. Ufa, Kungur, Menzelinsk, and Orenburg all successfully resisted the sieges of the rebels. The reasons for the failure of the rebels to capture these forts can be explained in material terms; they were short of fire arms, ammunition, artillery, especially heavier ones to breach the strengthened defensive walls of the towns, and most important of all they lacked experience, coordination and necessary training. ${ }^{52}$ Even though Cossack and Bashkir brigades were formidable soldiers in the open steppe, their cavalry units were useless before the fortified walls. ${ }^{53}$

So the rebels, despite their numerical superiority in the open field, never gained control of the larger garrison towns, which could have been decisive for the rebellion's success. At times

\footnotetext{
${ }^{51}$ Bashkir cavalry units used to serve in the Russian army and they had joined to the Seven Years' War and took part in the defeat of Frederick the Great. Herbert H. Kaplan, Russia and the Outbreak of the Seven Years' War, (Berkeley: University of California Press, 1968), 57.

${ }^{52}$ Vladimir V. Mavrodin, Krest'ianskaia Voina v Rossii v 1773-1775 godakh: Vosstanie Pugacheva, v. 2 , (Leningrad: Izd-vo Leningradskogo Universiteta, 1961), 228-229

${ }^{53}$ Paul Avrich, Russian Rebels, 1600-1800, (New York: W.W. Norton Company, 1972), 224.
} 
they even did not dare to attack relatively smaller garrisons as was the case before Troitsk fortress. In January 1774, two thousand Bashkirs and a number of Russian peasants, Cossacks and factory workers who had been sent to them as supplemental forces appeared before the gates of Troitsk and demanded the surrender of the fortress. Even though the defenders were greatly outnumbered, the garrison commander flatly refused to submit. By the end of February the siege of the fortress from all sides was firmly in place cutting all the contact with the other fortresses nearby. Despite the lack of any support for the defenders on the horizon the besiegers never stormed the walls of the fortress and they lifted the siege in March $1774 .^{54}$

As a result of these shortcomings rebel leaders had to race against the time and win remarkable victories while the main Russian army was away in the Turkish front. Only a series of quick victories could ensure the loyalties of those wavering elements of the local population. But after a few months of small successes and the capture of a number of small garrisons, the tide turned against the rebels and the already fragile coalition of rebels began to fall apart. Those Bashkir starshinas who were waiting for an opportunity to abandon the rebels after underlining the fragility of Pugachev's cause managed to persuade their own fellow Bashkirs and joined the punitive forces. The Russian sources named some of them like Bashkir Valishah Sharipov from Kazan Doroga, Sharip Kiikov from Osinsk Doroga, Mishar Bakhtiiar Ianyshev from Sibir Doroga, Bashkir Tupeev and several others. ${ }^{55}$

These desertions by no means brought an end to the rebellious cause of the Bashkirs because the reasons for their rebellion were still in place. Pugachev, thanks to charismatic Bashkir leaders like Kinzia Arslanov, Salavat Iulaev, Kachkin Samarov, and Mishar leader Kanzafer Usaev, still attracted Bashkir and other nationalities' support for the rebellion during

\footnotetext{
${ }^{54}$ I. M. Gvozdikova, Bashkortostan Nakanune i v Gody Krest'ianskoi Voiny Pod Predvaditelskom Pugacheva, (Ufa: Kitap, 1999), 335.

${ }^{55}$ I. M. Gvozdikova, Salavat Iulaev, Issledovanie Dokumental'nykh Istochnikov, (Ufa: Kitap, 1992), 177.
} 
the second stage which overwhelmingly took place in Bashkir territory. In May 1774 Pugachev was still in a position to command a 7000-strong multinational rebellious force before Magnitnaia.

On the other hand the Bashkir leaders who joined punitive expeditions of the government provoked more violence within the indigenous population. The rebels increased their pressures on the collaborators and widely punished those who joined the punitive forces or their relatives. In particular wealthy Bashkirs were victimized. In April 1774, 13 Bashkir and Tatar starshinas from Nogai and Kazan Dorogas, led by Kidrias Mullakaev ${ }^{56}$ from Nogai Doroga, appealed to general Bibikov, the Russian officer in charge of the campaign against the Pugachevshchina. They noted that supporters of Pugachev "took the advantage of the anarchy and victimized the rich people everywhere and those who had earlier submitted to the state and asked for forgiveness were compelled to escape towards the woods to save their lives from the wrath of the rebellious masses." ${ }^{57}$ This was the clear evidence of class conflict within the Bashkir society, a war between haves, who benefited from the Russian political system which relied on indigenous agents to continue its control of the region, and have-nots who were suffering from the existing regime, and they constituted the majority of the Bashkir society. Have-nots came especially from the eastern and southern parts of Bashkiria where the economic life of the indigenous people relied predominantly on a nomadic economy. These Bashkirs were the one who most fiercely fought on the side of Pugachev.

\footnotetext{
${ }^{56}$ Kidrias Mullakev was throughout his life loyal to the Russian state. He was a veteran of 1735-1740 Bashkir war who fought during the Seven Years' War. During the height of Pugachev's tide, he briefly joined him and settled his scores with a number of former rivals destroying their property and when the tide turned against Pugachev he abruptly appealed to the government and he took initiative to fight Pugachevtsy, defeating and capturing one of Pugachev's Atamans V. I. Tornov in April 1774 thereby gaining the trust of the government again. Finally he captured Kanzafar Usaev, the Mishar rebel leader in August 1774. Thanks to his loyal and successful services he managed to keep his position as starshina in his Kara-Tabynsk volost until the end of his life.

${ }^{57}$ R. G. Kuzeev and R. V. Ovchinnikov, comp., Krest'ianskaia Voina 1773-1775 gg. na Territorii Bashkirii, Sbornik Dokumentov, (Ufa: Bashkirskoe Knizhnoe Izdatel'stvo, 1975), 127-128.
} 
Unlike the Cossacks, the Bashkirs never had a single leadership. On the contrary they had a multitude of leaders from nearly every Bashkir volost. The most epic Bashkir leader was Salavat Iulaev, son of a famed Bashkir noble from Sibir Doroga, Iulai Aznalin who had served Russians in a number of occasions. Despite his fathers' fame Salavat won the pride of place in Bashkir history and Bashkir folk songs as the national hero of this people thanks to his great talents as a national poet and military leader. When the rebellion broke out, Iulaev's qualities of leadership, despite his young age (he was born in 1752) caught the eye of Pugachev who quickly elevated Salavat to the rank of colonel. He was a relative late-comer compared to Kinzia Arslanov. He joined Pugachev on 10 November 1773 when his brigade was sent against Pugachev by the governor of Orenburg, Reinsdorp, to suppress the rebellion. Instead he and his Bashkir-Mishar brigade, numbering 1200, joined Pugachev without a shot. This incident strengthened Pugachev's hand in attracting wavering Bashkirs to his side.

Salavat was the most important Bashkir leader in the second stage of the rebellion after Pugachev left Bashkiria in June 1774. His forces were multiethnic, composed of Bashkirs, Tatars, Russians, Mishars, Maris and others. He led both nomadic and sedentary peoples as fighters against the punitive forces. Thanks to his energetic leadership Pugachev on several occasions diverted the pressures of his relentless pursuers towards Salavat Iulaev who bore the brunt of the war after April 1774, thereby saving Pugachev's neck.

Iulaev's forces generally were composed of several thousand men and we do not know how he recruited non-Bashkir peoples to his regiments. But there are certain documents stating that Bashkirs did not hesitate to visit non-Bashkir villages and agitate them against the government. In one case a Bashkir brigade visited a Russian village near the town Kungur, one of the larger towns in northern Bashkiria. They tried to provoke people to join Pugachevshchina, 
addressing people about the forthcoming punitive expedition to the village on the grounds that they were sympathizers of Pugachev.

\section{The Bashkir Phase of the Rebellion}

The pretender finally left Bashkiria on June 21 and headed to Kazan after sacking Osa, the town at the western edge of Bashkiria, leaving Bashkir insurgents under Salavat behind. As a result the rebellion in Bashkiria took a new form; a war between loyal and rebellious Bashkirs. With the departure of the main rebellious army under Pugachev the loyal Bashkirs became more daring. They quickly formed punitive forces consisting of Bashkirs and unleashed a series of attacks against Salavat's forces. This period also witnessed a radical turn in the loyalties of the Bashkir starshinas. They increasingly appealed to the Russian authorities and asked for forgiveness. The chief official of the Kazan Secret Commission, ${ }^{58}$ P. C. Potemkin, in his report to Catherine II on November 10, 1774, just five days before Salavat was captured, stated that up to 200 Bashkir starshinas appealed to him asking for forgiveness. ${ }^{59}$ These Bashkirs not only asked for forgiveness but also worked hard to get favors from the authorities.

In May 1774, while Pugachev was still in Bashkiria, Bashkir rebels under Salavat and his father Iulai attacked Ust-Katavskii foundry, Kudeiskii Volost, Sibir Doroga, founded in 1758 by Ia. B. Tverdyshev and I. S. Miasnikov along with many others like Simskii, IuriuzanIvanovskii, and Katav-Ivanskii. Ust-Katavskii included 156 households with 809 people of both sexes in 1773 . This factory was one of the earliest factories that joined Pugachev's rebellion in

\footnotetext{
${ }^{58}$ Kazan Secret Commission lasted from December 1773 to March 1775.

${ }^{59}$ I. M. Gvozdikova, Bashkortostan Nakanune i v Gody Krest'ianskoi Voiny Pod Predvaditelskom Pugacheva, (Ufa: Kitap, 1999), 452.
} 
November $1773^{60}$ and had fiercely fought against Mikhelson's punitive force in May 1774. So it was one of the centers of insurrection. Despite this, proving the fact that Bashkirs were in fact fighting a desperate war against intruders, they chose this foundry as their target and evicted the workers and their families declaring, "You must leave your homes now because your time is over. Our fathers, having given you these lands are long dead and we do not want you here any longer." ${ }^{\text {61 }}$ The rebels in particular targeted factories and foundries which affected their life style in some ways more negatively than the settlements of the migrants. It is not an exaggeration to say that no other Russian institution created such hostility among them. These factories had become the agents of the most sinister subjugation of Bashkirs and their loss of status and impoverishment. Most of the time, Bashkirs were deceived by the factory owners who bought their lands at ridiculously low prices. No currency could pay the real price of Bashkirs' valuable land since they did not know what to do with the money and they could not buy anything with the Russian money in the region. Once they were relieved of their lands those Bashkirs were reduced to miserable conditions. ${ }^{62}$

This period also witnessed the rise of interethnic violence. This was dormant while Pugachev was in Bashkiria, but once he left the region for the Middle Volga, it reached its apogee. After the arrest of Pugachev on September 15, 1774, the Bashkirs intensified their attacks on the Russian settlements and factories. In early October 1774, Salavat Iulaev commanding a force of Bashkirs, Tatars, Mishars and Chuvash, attacked Katav-Ivanovskii Factory, burnt its buildings and a number of surrounding villages like Orlovka, Arskaia, Lomovka and Eral. It must be added that when the factory was burnt down, factory

\footnotetext{
${ }^{60}$ A. I. Andrushenko, Krest'ianskaia Voina, 1773-1775 gg., Na Iaike, v Priurale, na Urale, i v Sibiri,(Moskva: Nauka, 1969), 249.

${ }^{61}$ M. N. Martynov, "Satkinskii Zavod vo Vremena Vosstaniia Emel'iana Pugacheva” Istoricheskie Zapiski, 58 (1956), 242.

${ }^{62}$ These parts will be explained in greater detail in the colonization chapter.
} 
(possessional) peasants connived and even supported the rebels. This interesting act of collaboration on the part of the Russian factory peasants is not all that surprising. As General Shcherbatov noted, the factory peasants were mercilessly exploited by factory managers and this experience pushed them into the arms of the rebels. ${ }^{63}$ Most of these factory workers had been serfs, brought to the area from European Russia and they were yearning to return home. On the other hand this group of factory peasants was not monolithic. Within their ranks all sorts of people could be found due to the fact that as the industry developed in the region since the early days of the eighteenth century. The Russian industrialists increasingly demanded more and more workers for the newly established factories whose numbers reached more than one hundred especially in the southern Urals, the traditional homeland of Bashkirs. The government responded to these appeals with enthusiasm and "paupers, vagabonds, convicts, dissenters, tribesmen and other combustible elements were recruited for the metal works and mines." ${ }^{64}$ Salavat realized the dangerous potential of ethnic conflict among the Bashkir starshinas under his command. He was forced to appoint a Cossack, Semen Shemetev, as the commander of the El'diask fortress upon the requests of the Cossacks of the same fortress 'in order not to let the inovertsy (Bashkirs) do any harm to the Cossacks of the fortress."

Salavat's capture on 25 November 1774 by the state forces by no means ended the struggle of the rebels. Long after the arrest and exile of Salavat and his father Iulai to Rogervik there were still insurgent groups operating in the countryside harassing the local population and security forces. In Isetsk province for example, as late as 22 February 1775, it was reported that

\footnotetext{
${ }^{63}$ R. G. Kuzeev and R. V. Ovchinnikov, comp., Krest'ianskaia Voina 1773-1775 gg na Territorii Bashkirii, Sbornik Dokumentov, (Ufa: Bashkirskoe Knizhnoe Izdatel'stvo, 1975), 191.

${ }^{64}$ Paul Avrich, Russian Rebels, 1600-1800, (New York \& London: W. W. Norton Company, 1972), 199-200; N. M. Kulbakhtin, "Dinastiia Gornozavodchikov Osokinykh" Vatandash, 7, (2000)

${ }^{65}$ Vladimir V. Mavrodin, Krest'ianskaia Voina v Rossii v 1773-1775 Godakh: Vosstanie Pugacheva, v. 3 , (Leningrad : Izd-vo Leningradskogo Universiteta, 1961), 278
} 
persistent Bashkir groups remained at large under the leadership of starshina Baiazit

Maksiudov. ${ }^{66}$ So the complete pacification of the region took longer than the suppression of the Cossack insurgency. For fear of a resurgent rebellion, Russian forces remained in the region on alert through 1775 , more than a year after the capture of Salavat. In the meantime widespread persecutions by the Russian punitive forces took place, and especially those Bashkir villages which joined Salavat's forces suffered most. ${ }^{67}$ This is the evidence that the Bashkir rebellion eventually became independent of Pugachev's and they had their own designs for the future of their country like getting rid of at least Russian and other settlements which undermined traditional nomadic economy.

On the other hand this rebellion was the last rebellion of Bashkirs against the Russian government and militarily they emerged defeated. It was the clear expression of the success of the Russian government's attempts to encircle Bashkirs effectively through a string of defensive lines. Salavat as he approached his end desperately sought ways to escape to the Kazakh steppe to gather his forces again and renew his efforts in late October 1774, but all points of passage to the Kazakhs steppe had already been closed in the previous decades. So this last-ditch attempt to achieve Bashkir autonomy only became possible because of the emergence of a rebellious leadership, that of Pugachev's among the intruders, Cossacks and Russian population of the region. It also became clear that without giving serious concessions to Bashkirs, they would continue to be a stone in the boot. This was evident from the fact that some of the apparently most loyal Bashkir leaders had sided with the rebellion briefly despite all Russian attempts to reward their loyal services. Those who remained loyal to the government were rewarded by the

\footnotetext{
${ }^{66}$ A. I. Andrushenko, Krest'ianskaia Voina, 1773-1775 gg., Na Iaike, v Priurale, na Urale, i v Sibiri,(Moskva: Nauka, 1969), 309.

67 "Bumagi Grafa Petra Ivanovicha Panina o Pugachevskom Bunte " Sbornik Russkago Istoricheskago Obshchestva, 6, (1871), 193 and 207; "Graf Panin Usmiritel Pugachevshiny, Materialy Dlia Istorii Pugachevskogo Bunta," Russkii Vestnik, 80:3 (1869), 166.
} 
government; 26 Bashkir starshinas were rewarded golden and silver medals from the senate; seven were given official titles and many others received money, swords and other rewards.

Salavat Iulaev played a key role in the development of Bashkir national identity and Bashkirs' sense of motherland thanks to his superb poetry in which he time and again stressed the importance of a motherland for the Bashkir people. His poem "Tovgan Ilim" (the country where I was born) is the most remarkable expression in this context;

The prairies where I was born

My waters sweeter than honey

My plains and forest

My skyscraping Urals

My sacred place

My heart loves you all ${ }^{68}$

It must be borne in mind that Salavat, as one of the last true sons of the Bashkir nomadism, strongly emphasizes the beauty of the steppe, not the Bashkir settlements. In another poem written in the dungeons of Rogervik, where he was banished, he appealed to Bashkirs and Bashkiria without making any distinctions between sedentary or nomadic Bashkiria:

My beloved motherland! You are far away.

I would want to return to you

I am in the chains, O Bashkirs!

Snow covers my way

But it thaws in the spring

\footnotetext{
${ }^{68}$ Ahmet Suleymanov, ed., Baskurt Edebiyati, v. 1, (Ankara: T. C. Kultur ve Turizm Bakanligi, 1993), 258.
} 


\section{I am not dead O Bashkirs! ${ }^{69}$}

\section{Conclusion}

The end of Salavat is also the end of Bashkirs' fighting spirit against the centralizing policies of the Russian government. There were no more Bashkir rebellions for freedom except a minor riot in 1835. By the time of Salavat's death in the late 1790s Bashkir spirit for freedom was no more because by this time they were something completely different from the Bashkirs of the early $1700 \mathrm{~s}$. By the end of the eighteenth century there were more sedentary Bashkirs than nomadic ones. The more they were sedentarized the more capably they were able to deal with the intruders. To be able to deal with the intruder means the preservation of the Bashkir national identity and its defining tenets like language and religion. So in the final context Bashkirs emerged victorious in the face of irreversible socio-economic, cultural and demographic changes imposed by the intruders. The real use of those century-long wars for Bashkirs, despite their destructiveness, was the molding of Bashkirness.

The Pugachev rebellion and the Salavat's leadership were crucial events in the history of Bashkirs. From a certain perspective this rebellion played the most significant role for the formation of the Bashkir ethnic identity as was explained above. Salavat was certainly the first national hero whose influence lasted to this day. He can easily be portrayed as the first Bashkir nationalist who raised the steppe people of Bashkiria for a fight to oust alien elements, most significantly Russians from the Bashkir lands.

\footnotetext{
${ }^{69}$ Iu. A. Limonov, Pugachev i Ego Spodvizhniki, (Moskva-Leningrad: Nauka, 1965), 138; This tradition set by national poets like Salavat was continued in the next century by other Bashkir folk poets. In a society where literacy is extremely confined to a tiny portion of the society the determining role of intellectuals was played by folk poets who recited in the simplest language so that even the most ignorant sections of the society could get the message.
} 
This rebellion was a good example of the new imperial and frontier history from several perspectives. It has become clear that imperial Russian authorities had no intention to remove indigenous population from their lands. There were no deportations and no massive penalization of those who fought against the government. The loyal Bashkirs were generously rewarded and thereby their services were guaranteed. As Ronald J. Robinson called, it was a "collaborative mechanism" which served both parties well. ${ }^{70}$ Such a system was the centerpiece of Russian empire building in the steppe region for several centuries. ${ }^{71}$ The events in the aftermath of the Pugachev rebellion do not contradict with this traditional Russian imperial policy. Those rebels who wavered were attracted to the Russian side with material rewards and promises of tolerant treatment of those who were repentant. Their social status was guaranteed and some of them were even promoted as has been explained in the case of Kulyi Baltachev above.

Catherine the Great's post-Pugachev policies in Bashkiria were designed to bring a long lasting peace to Bashkiria. In order not to cause further disturbances her administration's treatment of those rebellious Bashkirs was relatively mild when Salavat's punishment was put into consideration. Though he was heavily tortured he was not executed just like Pugachev. Some other Bashkir rebel leaders were even rewarded for their services to the punitive forces after they reneged. The authorities for a brief period considered fining rebellious Bashkirs heavily. Those Bashkirs who took part in the rebellion were forced to pay their fine in horses but considering Bashkirs' wretchedness economically this fine was commuted to 25 rubles. By the end of 1775, 13,409 Bashkir households paid 78,691 rubles, nearly 5 rubles per household

\footnotetext{
${ }^{70}$ Ronald Robinson, "Non-European Foundations of European Imperialism: Sketch for a Theory of Collaboration," in Studies in the Theory of Imperialism, ed. Roger Owen and Bob Sutcliffe (London: Longman, 1972), 117-42.

71 Jeff Sahadeo, "Conquest, Colonialism, and Nomadism on the Eurasian Steppe" Kritika: Explorations in Russian and Eurasian History, 4, (Fall 2003), 948.
} 
instead of 25 rubles. $^{72}$ Though this amount may seem large, it must be considered that there were no deportations or widespread state terror to intimidate the population further. Catherine the Great's administrators were pragmatic enough to create an agricultural Bashkir community and thereby to populate Bashkiria, an imperial policy which resembles Theodosius the Great's attitude towards the Visigoths. ${ }^{73}$

The Bashkirs' persistent fighting and ardent participation in the rebellion could be evidence that Bashkiria was still a frontier rather than a borderland. By the end of the rebellion, however, it had become clear that Bashkiria was an effectively bordered land. All their external contacts in particular with the Kazakhs were cut. The number of forts, outposts and fortresses that surrounded Bashkir lands was 77 by $1750 .{ }^{74}$ Accordingly the Russian government at the end of the Pugachevshchina effectively claimed dominion in Bashkiria. With it, Bashkirs lost their ability of maneuver and mobility since the free passages through the Russo-Kazakhs border was effectively cut. Bashkirs could no longer rebel against the state and the authorities were sure of their authority in the region. When a colonial state effectively closes the borderland, intercultural frontiers yield to hardened and more exclusive hierarchies. ${ }^{75}$ The middle ground fades away and the defeated party (Bashkirs) is subject now to the socio-cultural domination of the intruder (Russians and other settled groups).

\footnotetext{
${ }^{72}$ I. G. Akmanov, ed., Istoriia Bashkortostana s Drevneishikh Vremen do Nashikh Dnei v Dvukh Tomakh, v. 1, (Ufa: Kitap, 2007), 261.

${ }^{73}$ Stephen Williams \& Gerard Friell, Theodosius: The Empire at Bay, (Routledge: London, 1998), 27

${ }^{74}$ Alton S. Donnelly, The Russian Conquest of Bashkiria, 1552-1740: A Case Study of Imperialism, (New Haven \& London: Yale University Press, 1968), 176-177.

${ }^{75}$ Jeremy Adelman and Stephen Aron, "From Borderlands to Borders: Empires, Nation-States, and the Peoples in between in North American History" The American Historical Review, Vol. 104, No. 3 (Jun., 1999), 816.
} 


\section{Chapter 5 \\ The Colonization of Bashkiria, 1730s to 1790s}

Sedentarization is a very radical transformation for any nomadic or semi-nomadic society and its swift occurrence can only take place under drastic socio-economic or political upheavals. Without such conditions, sedentarization may never take place or may take much longer, maybe a thousand years. Without external factors few nomadic communities would seek a radical shift in their traditional life styles. ${ }^{1}$ The lack or weakness of native political institutions may seriously affect a tribal society's decision to sedentarize or continue nomadism. Social differentiation and the loss of the herds of the poor nomads force them to adapt themselves to a new economic life, but such cases are extremely rare and short-lived. ${ }^{2}$ On the other hand radical political changes (i.e. conquest) in the areas where nomads roam may trigger radical socio-economic alterations by destroying the natural rhythm of nomadism and may make a swift sedentarization possible, as will be explained below.

The colonization of Bashkiria by Russian and non-Russian peoples was a phenomenal event in the history of the Bashkirs. It was the most important reason for many Bashkir rebellions against the Russians and it consequently molded Bashkir identity. The colonization also brought a radical shift in the mode of Bashkir living. It had destructive as well as constructive consequences for these nomadic people. Colonization left them no option but to embrace a semblance of their colonizers' culture which made them sedentarize gradually and thereby brought them closer to their Russian masters and non-Russian neighbors. Doubtless,

\footnotetext{
${ }^{1}$ Interestingly Jeremy H. Keenan also makes a similar remark arguing that sedentarization is seldom a voluntary process and mostly it is imposed by an external pressure, either environmental or political but in any case it is the least desired process for nomadic societies. Jeremy H. Keenan, "Sedentarization and Changing Patterns of Social Organization amongst the Tuareg of Algeria", in Nomadic Societies in the Middle East and North Africa: Entering the 21 st Century ed. Dawn Chatty, (Leiden: Brill, 2006), 916.

${ }^{2}$ Ole Bruun, Precious Steppe: Mongolian Nomadic Pastoralists in Pursuit of the Market, (Lanham, MD.: Lexington Books, 2006), 170
} 
sedentarization is a difficult process for the nomadic societies and it entails enormous adjustment difficulties. So it must be a gradual process which requires many generations but Bashkirs did not have so much time since they were under the control of an alien culture which paid no heed to Bashkirs' traditional form of life.

\section{Historiography}

While there are many works about Bashkir people, the colonization issue in imperial Russian historiography has not been studied from the perspective of Bashkirs aside from brief references to the Russians' arrival in the region and their creation of settlements. Almost all imperial Russian historians who have written about the Bashkir rebellions identified the colonization in the region and land seizures as the main reason for these rebellions. They usually have viewed the history of the colonization of the region from the Russian perspective. ${ }^{3}$ Two historians, however, Cheremshanskii and Vitevskii, did address the colonial history of the Bashkirs. ${ }^{4}$ These two historians of the Imperial period produced the first works on the Bashkir economic life and political history covering a period between the sixteenth and the twentieth centuries and the history of peoples in southern Urals and nearby regions (Priural'ia) and they set the standards for future generations in writing Bashkir history. ${ }^{5}$

The Soviet and post-Soviet historiography paid more attention to colonization of Bashkiria from the perspective of Bashkirs but they rarely studied the process through which

\footnotetext{
${ }^{3}$ A. I. Dobrosmyslov, "Bashkirskii Bunt v 1735, 1736 i 1737 g." Trudy Orenburgskoi Uchenoi Arkhivnooi Kommissii, no: 8, (Orenburg: 1900); M. Svirelin, "Kolonizatsiia Orenburgskogo Kraia v Pervoi Polovine 18 v." Drevniaia i Novaia Rossiia. v. 6-7, (1876); A. Dimitriev, "K Istorii Zaural'skoi Torgovli Bashkiriia pri Nachale Russkoi Kolonizatsii” Permskaia Starina. Sbornik Istoricheskikh Statei i Materialov Preimushchestvenno o Permskom Krae, v. 8,. (Perm: 1900); V. A. Novikov, “Ocherk Kolonizatsii Bashkirskogo Kraia” Istoricheskaia Biblioteka, v. 3, no:12 (1878)

${ }^{4}$ V. M. Cheremshanskii, Opisanie Orenburgskoi Gubernii i Khoziaistvenno-Statisticheskom, Etnograficheskom $i$ Promyshlennom Otnosheniakh, (Ufa, 1859); V. N. Vitevskii, I. I. Nepliuev i Orenburgskii Krai v Prezhnem Ego Sostave do 1758, Three volumes (Kazan: 1889-1897)

${ }^{5}$ For greater detail see R. G. Kuzeev, Arkheologiia i Etnografiia Bashkirii, v. 3, (Ufa: 1968), 262.
} 
Bashkirs completed their sedentarization. Some of the clichés from the imperial Russian historiography were preserved while new clichés were produced like 'Russian conquest and Russian colonization of the region had a progressive effect on the indigenous peoples.' The unavoidable price of this transformation and the invisible side of this progressive result were almost never studied. ${ }^{6}$

Among the Soviet historians of Bashkir history, Ravil Kuzeev focused most specifically on Bashkir tribal life, the development of the Bashkir economy from nomadism to sedentarization and the formation of Bashkir identity under the Russian empire. He argued that Bashkir economic life was for most of their history based on nomadism and semi-nomadism which lasted nearly one thousand years. He further argues that there was a slow process in Bashkir history from the fourteenth century towards sedentarization.

Imperial and some Soviet historians claimed that the Russian conquest of the region had a positive effect on the lives of Bashkirs because it made the Bashkirs sedentarize. This claim does not reflect the whole truth because Bashkirs in the regions adjacent to the former Kazan khanate had already been sedentarized farmers before the arrival of Russians. Long before the beginning of the full scale colonization of the region, individual Bashkir groups had already

\footnotetext{
${ }^{6}$ There are a number of works and articles from the Soviet and post Soviet period relating to the colonization of the region by the Russian and other nationalities: Kh. F. Usmanov, "Krest'ianskaia Kolonizatsiia Bashkirii v Poreformennyi Period” Stranitsy Istorii Bashkiri. Sbornik Statei, (Ufa: BFAN SSSR, 1974), 67-112; F. Gumerov, "Zakony Rossiiskoi Imperii i Kolonizatsiia Bashkortostana", Vatandash, 4, (1998); F. Gumerov, "Zakony Rossiiskoi Imperii o Bashkirskikh Zemliakh" Vatandash, 6, (1998); R. N. Zinurov, "Kolonizatsiia Bashkortostana i Severnoi Ameriki" Vatandash, 2, (1998); Iu. M. Tarasov, Russkaia Krest'ianskaia Kolonizatsiia Iuzhnogo Urala: Vtoraia Polovina 18 - Pervaia Polovina 19 v. (Moskva: Nauka, 1984); R. N. Zinurov, "Istoricheskie Paralleli Nachala Kolonizatsiia i Severnoi Ameriki" Iadkiar, 2, (1999); Iu. M. Tarasov, "Russkaia Krest'ianskaia Kolonizatsiia Iuzhnogo Urala v 17 i 18 vv.” Uchenye Zapiski Kishinevskie Gos. In-ta Seriia Istoricheskaia, 95, (1968); N. V. Ustiugov, “Osnovnye Cherty Kolonizatsii Iuzhnogo Zaural'ia v 18 v.” Voprosy Istorii Sibiri i Vostoka, (Novosibirsk: 1961); The argument promoting Russians' progressive role in the lives of the eastern peoples is challenged more often by various scholars. Two of them Caroline Humphrey and David Sneath partly examine Buryat society of eastern Siberia and argue that even before the arrival of Russians to Buryat lands there was a gradual process towards sedentarization among Buryats though they were more mobile at the time. Caroline Humphrey and David Sneath, The End of Nomadism?: Society, State, and the Environment in Inner Asia (Durham: Duke University Press, 1999), 188.
} 
achieved varying degrees of sedentarization and shifted to agricultural production. The reports by the Russian officials and Russian settlers to this end reflect a partial truth that even in the regions where nomadic forms of life seemed inescapable like Nogai doroga, Bashkirs were moving to an agricultural form of life. ${ }^{7}$ While the Russian conquest of Bashkiria accelerated the process towards sedentarization in the region at a great human and material cost, even without Russian conquest Bashkirs were in a process of sedentarization and becoming an agricultural society albeit a very slow and awkward one.

In the west the best studies that address the colonization of Russia's steppe region are those of Michael Khodarkovsky and Willard Sunderland. Both scholars extensively analyzed the Russian governmental policies in the steppe region over the centuries and the results of such policies for both the colonizer and the colonized. Both studies provide valuable insights into Russia's penetration into the steppe and consolidation of its authority over the centuries. On the other hand neither study provides a detailed account of Russo-Bashkir relations and natives' complex responses to the colonization of the steppe.

\section{Russian Government Policies}

The frontier groups are the peoples of the "open spaces" with no state of their own. Such places had long been attractive for people who were overburdened by the demands of the central governments. These spaces were centers of resistance because rebellious elements of such a society would locate in such regions. Russian authorities especially with the beginning of the 1700 s increasingly defined such places as the regions of barbarity and anarchy. In these areas there was neither state, nor tsar, nor order because in the absence of these such spaces were the

\footnotetext{
${ }^{7}$ Materialy po Istorii Bashkirskoi Istorii, part 1: Bashkirskie Vosstaniia v 17 i Pervoi Polovine $18 v v$. (Moskva\&Leningrad: Izdatel'stvo Akademii Nauk SSSR, 1936), 204.
} 
abode of bandits, rebels and princely pretenders, such as Pugachev. Any ambitious ruler would spend efforts to establish his control in such spaces. The main instruments of establishing such a control were "sedentarization, concentration, order and legibility.",

The governments' plans relating to Bashkiria were not predetermined but evolved in time. Accordingly colonization of the area followed different patterns from the 1550 s to the early twentieth century. History has proven that Ivan IV's land grant to Bashkirs was a temporary one as one Bashkir historian contends. F. Kh. Gumerov argues that initially the Russian attitude towards the Bashkirs was a very restrained one. The Russian tsars from 1552 to the early years of the eighteenth century most of the time avoided violating Bashkir votchina rights partly because they did not have enough military might in the region and partly because there were more urgent problems. ${ }^{9}$

Imperial Russian historian V. N. Vitevskii in this context brings a very traditional view forward about the colonization of Bashkiria and argues that as the Russian colonization in Bashkiria grew stricter and more pervasive, land seizures in Bashkiria, in violation of the land charter that Ivan IV granted to Bashkirs, took place in an unbridled way. Consequently Tsar Alexei Mikhailovich forbade colonization in Bashkiria and prohibited the migration of people from European Russia, and land acquisition in Bashkiria for any reason. This rule was added into the 1649 Law Code. Despite this however, land seizures continued in Bashkiria as before with the connivance of the Tsars. ${ }^{10}$ The state authority in the region was militarily still weak

\footnotetext{
8 James C. Scott, "Freedom and Freehold: Space, People, and State Simplification in Southeast Asia" in Asian Freedoms: The Idea of Freedom in East and Southeast Asia, ed. David Kelly \& Anthony Reid, (Cambridge \& New York: Cambridge University Press, 1998), 54. Italics belong to Scott.

${ }^{9}$ F. Kh. Gumerov, compiler, Zakony Rossiiskoi Imperii o Bashkirakh, Mishariakh, Teptiariakh i Bobyliakh (Ufa: Kitap, 1999), 87.

${ }^{10}$ F. Kh. Gumerov, compiler, Zakony Rossiiskoi Imperii o Bashkirakh, Mishariakh, Teptiariakh i Bobyliakh (Ufa: Kitap, 1999), 87.
} 
despite governmental attempts to construct defensive lines in the region and the tsars in the seventeenth century feared that Bashkirs could rebel and shake Russian authority in Bashkiria.

On the other hand because of the spread and intensification of serfdom in European Russia there was a growing Russian peasant movement into the region which the central authority could not prevent. The Russian Tsars in their first period of rule in Bashkiria had no clear cut plans about the Bashkirs. In order not to risk a decline in Iasak collection arguably they attempted to prevent colonization in the area. The other motive for their ban on the colonization of the Bashkir lands may have been the shortage of manpower experienced in central regions of Russia. So for the first hundred and fifty years or so of Russian rule, Bashkiria witnessed spontaneous colonization by fugitives in the region and the encounters between Bashkirs and the Russian settlers remained limited.

The first period lasted until the second half of the seventeenth century. The northern and northwestern parts of Bashkiria witnessed colonization. Russian peasants in this area considering the suitability of the climate and type of soil for agriculture started their first settlements without authorization of the government and ignored Bashkir hostility. Not surprisingly the first settlers arrived to the region after the establishment of the first fortresses in the area.

The second stage, from the 1650 s to the 1730 s, was more organized and more statedirected but again lacked a massive character. Settlements moved further east and south east. The lands as far east as modern day Cheliabinsk, (216 miles from Ufa), the foundations of which were laid in 1736 by Kutlu Mukhammed Tevkelev, and Kurgan (369 miles from Ufa), founded in 1679 , witnessed the creation of settlements. But the pace of the creation of settlements was 
slowed down by the insecurity of the area and the attacks of the nomadic groups. During this period many Russian settlements like Kungur and Birsk were burnt down. ${ }^{11}$

The colonial powers usually sought to increase their revenues as their imperial claims increased. By the time of Peter the Great, the Polish wars of the seventeenth century had added an enormous financial burden on the Russian treasury and Peter the Great's imperial ambitions brought the Russian economy under even more strain. The Russian state fought wars in the west against Sweden (1700-1721) and in the south against Ottoman Empire (1696-1699 and 1711). Under such dire financial difficulties, the Russian government attempted to bring idle lands of Bashkiria into active use for farming, mining, and other purposes, guided in part by developing Russian mercantilist thought in the mid-seventeenth century. ${ }^{12}$ The exploitation of these lands required extension of greater control by the Russian government and in the process radically transformed the lives of the indigenous peoples.

The third period from the 1730 s to the beginning of the twentieth century was the era of great transformation in terms of demographic structures and economic relationships. By the end of this period Bashkirs were only the third most populous group in their own native lands and they were to a great degree sedentarized, although a few Bashkir groups remained nomadic. ${ }^{13}$ The Russian government took every measure to increase the population of the region and in a

\footnotetext{
${ }^{11}$ Petr Ishcherikov, Ocherki iz Istorii Kolonizatsii Bashkortostana: Ot Zavoevaniia Bashkortostana do Epokhi Pashkishcehiia Bashkirskikh Zemel' (Ufa: Kitap, 2003), 14.

${ }^{12}$ Mercantilist thought first came to Russia around mid seventeenth century. The first active protagonist of this view was A. L. Ordin-Nashchokin, a provincial elite from Pskov who advocated mercantilist efficiency in Russia as found in the west. See Richard Hellie, "The Economy, Trade and Serfdom" in The Cambridge History of Russia: From early Rus' to 1689, Volume 1, From Early Rus to 1689. ed. Maureen Perrie, D. C. B. Lieven, Ronald Grigor Suny, (Cambridge \& New York: Cambridge University Press, 2006), 545; For a detailed analysis of the Russian mercantilism in the seventeenth century see Jarmo T. Kotilaine, "Mercantilism in Pre-Petrine Russia" in Modernizing Muscovy: Reform and Social Change in Seventeenth-Century Russia, ed. Jarmo Kotilaine \& Marshall Poe, (Routledge: London, 2004), 137-166

${ }^{13}$ Iu. M. Tarasov, Russkaia Krest'ianskaia Kolonizatsiia Iuzhnogo Urala: Vtoraia Polovina 18 - Pervaia Polovina 19 v. (Moskva: Nauka, 1984), 54-55; Tarasov's book is one of the best works pertaining to the region and its colonization by the Russians. He, however, overemphasizes the "progressive" role of the Russian peasants in the transformation of Bashkirs and in many respects his work lacks a critical analysis of the sources in issues relating to the Bashkirs' responses to the Russian colonization of the region.
} 
much more organized way opened the Bashkir lands to the colonization, totally ignoring earlier guarantees by the Russian tsars about the protection of Bashkir votchina rights.

\section{Actual Migrations}

The first Russians had appeared in the Bashkir lands as early as 1468, intending to trade for furs with Russian goods. These Novgorodian Russians did not stay long enough to leave their imprint in the region but nearly a century later the Muscovite Russians appeared in Bashkiria again, this time in the form of officials and Cossacks who had intended to stay in the region for political and military motives rather than for the purposes of trade. Initially their main concern was to collect Iasak from the indigenous people as was discussed in the first chapter.

These Russian officials and soldiers were followed shortly afterward by ordinary Russian peasants who escaped from the yoke of the government under Ivan the Terrible. They continued to arrive to the region because of the catastrophe of the Time of Troubles that left the countryside in ruins. But not all those non-Russian peoples escaped from increasing governmental control. On the contrary some of them were encouraged by the government to settle down in parts of western Bashkiria around the Kama River. The Russian authorities first opened state lands to colonization in eastern parts of Kazan region. The stated goal was to create free farmers (zemledelets), not bound by local gentry, in the frontier region. These settlements during the seventeenth century made great inroads in western and northern Bashkir lands. ${ }^{14}$ Bashkir lands to the east of Kama region remained within the limits of the land grant by Ivan the Terrible in the 1550s and therefore Bashkirs never tolerated the state sponsored land distribution.

\footnotetext{
${ }^{14}$ N. F. Demidova, "Upravlenie Bashkiriei v Pervoi Treti 18 v.” Istoricheskie Zapiski, 68 (1961), 219; U. Kh. Rakhmatullin, Naselenie Bashkirii v 17-18 vv Voprosy Formirovanie Nebashkirskogo Naseleniia, (Moskva: Nauka, 1988), 98-99; A. A. Spitsyn, “Obrochnye Zemli na Viatke v 17 v. Kazan, 1893” Izvestiia Obshchestva Arkheologii, Istorii I Etnografii pri Kazanskom Universitete, 10, (1892).
} 
The fugitive Russians were not great in numbers, but it must be stressed that they were the most daring and enterprising ones of their society who readied themselves to take on the onerous and dangerous life in the frontier areas. For a very long time Russian governments forbade the colonization of the Bashkir lands and in this context the trade of the Bashkir lands was prohibited in a number of decrees and laws, the most important of which was stated in the Law code of $1649 .^{15}$

These laws to prevent fugitive peasants from settling in the Bashkir frontier areas were futile for two reasons. First, the pressure of the government in the form of military recruitment, forced construction labor and taxation in European Russia was too great, which left the vigorous Russian peasants no alternative but to flee. The second factor was that the early Russian presence in the region was military. Therefore there was a string of fortifications in the region which provided at least a minimal sense of security for the newcomers. These Russian troops and officials in the region needed provisions from the center which were not easy to send, so they increasingly relied on the labors and surplus food produced by these illegal settlers in the region. Since most Bashkirs had no habit of producing surplus agricultural goods at this stage of their history the only alternative to achieve this was to get provisions from these Russian settlements.

The Russian fugitives were not the only ones who appeared as intruders in the region after 1552. There were also a large number of Tatar refugees whose property had been destroyed by the Russian forces in the aftermath of the fall of Kazan to Russians in 1552. The Russian government tried to force these people deprived of their khanate to convert to orthodoxy, and many refused to submit. The only alternative for these people was to escape to the regions where

\footnotetext{
${ }^{15}$ Richard Hellie, trans., The Muscovite Law Code (Ulozhenie) of 1649 Part 1 (Irvine, California: Charles Schlacks jr., 1988), 112
} 
the Russian control was weak or non-existent and these people found temporarily a safe haven in Bashkiria. So these Tatars formed another intrusive group who endangered the traditional life of Bashkirs.

There were other groups like Mishars who had been mainly transferred to the region by the Russian government. Ethnically speaking Mishars could be considered a sub-Tatar group with some slight differences in their accents and their physical appearance. They are mentioned in the Russian sources as Meshcheriaks or at times simply Tatars. But their history differed from those people known as Kazan Tatars because the defining feature of their history was their long association with the Russian state. ${ }^{16}$ As Muscovite Russia expanded towards the East, Mishars were also transferred in that direction as the service people to serve the Russian state. Their services were more valuable than those of the Cossacks in Bashkiria because these people were ethnically, linguistically and religiously from the same background as Bashkirs. Their loyal services to the Russian state combined with their affinities with the Bashkirs to facilitate the integration of Bashkirs into the Russian state system.

There were also some other groups whose ethnic composition is still a matter of debate. These are the above-mentioned Teptiars ${ }^{17}$ and Bobyls. ${ }^{18}$ I. K. Kirilov described the Teptiars as a mixture of Tatars, Chuvash, Mordvins, and Votiaks, who since time immemorial continued to

\footnotetext{
${ }^{16}$ Allen J. Frank. Muslim Religious Institutions in Imperial Russia: the Islamic World of Novouzensk District and the Kazakh Inner Horde, 1780-1910, (Boston: Brill, 2001), 60.

${ }^{17}$ There are various definitions about the term Teptiar. One of them claims that Teptiar is not the name of a specific ethnic group but a name for the tenant on Bashkir land. See; Francine Hirsch, Empire of Nations: Ethnographic Knowledge \& The Making of the Soviet Union, (Ithaca: Cornell University Press, 2005), 113 This definition belongs to Soviet anthropologist and ethnographer David Zolotarev (1885-1935). Another account asserts that Teptiars were the descendants of Tatars and Bashkirs who were culturally and linguistically Bashkirized and they were considered ethnically distinct group until 1930s. Wixman Ronald, The Peoples of the USSR: An Ethnographic Handbook, (Armonk, N.Y. : M.E. Sharpe, 1984), 190. This information contradicts with that of Allen J. Frank who has argued that Teptiars ceased to exist as a separate nation after 1926 when the Soviet census was taken that year. Allen J. Frank, Islamic Historiography and Bulghar Identity among the Tatars and Bashkirs of Russia (Leiden: Brill, 1998), 8. The literal meaning of the word Teptiar was nothing but a Persian word daftar, register or notebook.

${ }^{18}$ Bobyls are even more difficult to define than Teptiars. Literally Bobyl means single man. They were migrants mostly from Middle Volga region from a mixed ethnic background similar to those of Teptiars and found haven among Bashkirs and became unregistered landless peasants in Bashkiria.
} 
live in Bashkir lands. Bobyls on the other hand were still coming to the region. Teptiars and Bobyls were two similar groups with different names. The former one is called settler (pripushcheniki), whom Bashkirs allowed to settle in Bashkir lands and they paid tribute or Iasak to the Bashkir landlords; these transactions are recorded in an inventory. The Bashkir landlords then transferred this revenue to the state treasury for their own Iasak payment. ${ }^{19}$ These two groups seem to have played a more distinctive role for Bashkirs' ethnic composition by the end of the eighteenth century because they mostly lived side by side with Bashkirs, had closer contacts and accordingly it was easier to form marital unions with them.

While Teptiars concluded written agreements that determined the quantity and size of the land and obligations, Bobyls settled without written conditions. Their numbers with respect to the Russian settlers in the early 1630 s were huge. ${ }^{20}$ These people, pure refugees, were more than willing to join the ranks of Bashkirs. They wanted to be registered as Bashkirs because Bashkirs were at the time considered privileged people. So in the long run it was no surprise that many of these people were assimilated into the Bashkir culture after spending so much time with their neighbors but never abandoning their sedentary culture. While no scholarship is available on relations between the Bashkirs and the Bobyls and Teptiars, some considerations make it likely that these groups contributed to the Bashkirs' adoption of this pattern of life gradually.

State-sponsored systematic colonization of Bashkir lands started after the official foundation of Orenburg Guberniia in 1744. Prior to this date, colonization was spontaneous and on occasions due to the security concerns of the tsarist authorities it was confined to the Tatar service people, Mishars who showed competence in suppressing Bashkir rebellions. Deti

\footnotetext{
${ }^{19}$ Materialy po Istorii Bashkirskoi ASSR, v. 3, (Moskva \& Leningrad: Izdatel'stvo Akademii Nauk, 1949), 493; Dina Mustafina, "Materialy o Bashkirskom Vozmushchenii 1735 Goda" in Gasyrlar Avazy, 3/4 (1999)

${ }^{20}$ N. G. Ustiugov, et.al., Ocherki po Istorii Bashkirskoi ASSR, v. 1, part 1, (Ufa: Bashkirskoe Knizhnoe Izdatel'stvo, 1956), 97.
} 
Boiarskie (literally Sons of Boyars but in fact lower ranking nobles) were granted Bashkir lands by the government. This could be interpreted as evidence that Russian tsars considered Votchina Bashkir lands as their own. It can also be argued that the real reason for their prohibition of colonizing Bashkir lands was that they did not want to lose control of the events in Bashkiria. They were also reluctant to let Russian peasants slip out of their control when Russian was entering a period of feudalization and tying the peasants to the land and subjugating them to their lords.

In the eighteenth century Orenburg Gubernia covered a large area including historical Bashkir lands and more. It stretched from the Kama River in the north to the Caspian Sea in the south which had never been a Bashkir land but a Nogai country and from the Volga River in the west to the Tobol River in the east. The climatic conditions were suitable for the production of crops for a traditional peasant society; wheat, rye, barley. The size of the Gubernia was around 35 million desiatinas ${ }^{21}$ and most of the arable land was black earth. ${ }^{22}$

The natural riches of the region were attractive for the settlers; the rivers abounded in fish, the forests were thick which provided wood for construction and heating and beekeeping in the forest was a traditional occupation of the native people. The diet of the people could be supplemented with wild game as well. So the region became one of the focal points for the settlers after the $1550 \mathrm{~s}$. On the other hand, one of the major characteristics of this early colonization was that most of the settlers were non-Russians; Volga Tatars, Mishars, Chuvash, Mansi, Votiaks and Bobyls and Teptiars. During the two centuries before the foundation of Orenburg Gubernia, Russians came to the region only in small groups. Often they had to fight

\footnotetext{
${ }^{21}$ I. G. Akmanov and Aznagul Uruskulov, ed. Bashkirskaia Entsiklopediia, v. 3 (Ufa: Nauchnoe Izdatel'stvo, 2005), 56

${ }^{22}$ Willard Sunderland, Taming the Wild Field: Colonization and Empire on the Russian Steppe (Ithaca, N.Y.: Cornell University Press, 2004), 165.
} 
against harassment by indigenous peoples and against efforts by Russian officials to keep them out of the region with orders from the central government. So those who managed to make their way to the region were the most energetic and adventurous ones. These were the people who escaped from the oppression of Ivan IV's oprichnina or from the chaos of the Times of Troubles.

Even though the government prohibited the sale of the Bashkir lands to the newcomers either Russians or non-Russians, its other policies in the region in fact produced opposite results. The construction of defensive lines, fortresses, later towns, and strong points brought a sense of security to the region gradually and accordingly the flow of Russian peasants to the region accelerated especially after the completion of trans-Kama defensive line in the $1650 \mathrm{~s}$. As the defensive lines were moved further east during the following decades, the number of migrants increased and step by step Bashkir lands which once provided a fertile ground for the Bashkir herds were lost to agricultural fields. ${ }^{23}$

The real number of Russian settlers in the region in the sixteenth and first half of the seventeenth centuries is not fully known but it is clear that their numbers were not more than a few thousands until the 1650s. On the other hand, the number of Russian fortress towns was growing steadily. During this period Menzelinsk, Sheshminsk, Akhtachinsk, Birsk, Tabysnk and others were founded and were manned by the Russian officials, streltsy and others whose numbers were not sufficient to pacify the Bashkir rebelliousness. ${ }^{24}$ But these defensive points were adequate enough for intruders to seize the land. In the early seventeenth century a village

\footnotetext{
${ }^{23}$ For the process of the construction of the defensive lines along Russia's southern steppe frontier see, Carol Belkin Stevens, Soldiers on the Steppe: Army Reform and Social Change in Early Modern Russia,(DeKalb, Northern Illinois University Press, 1995); Alton Donnelly also explains the process of the construction of Trans-Kama, New Trans-Kama and Orenburg defensive lines and their political, economic and psychological effects on Bashkirs. Alton S. Donnelly, The Russian Conquest of Bashkiria, 1552-1740: A Case Study of Imperialism (New Haven and London: Yale University Press, 1968)

${ }^{24}$ U. Kh. Rakhmatullin, Naselenie Bashkirii v 17-18 vv Voprosy Formirovanie Nebashkirskogo Naselenia, (Moskva: Nauka, 1988), 48; F. Kh. Gumerov, compiler, Zakony Rossiiskoi Imperii o Bashkirakh, Mishariakh, Teptiariakh $i$ Bobyliakh (Ufa: Kitap, 1999), 88.
} 
called Duvanei was founded not far away from Birsk of Osinsk Doroga where the defensive strength of the Russian administration was much higher. As the population of the village grew the extra population left the village and settled in nearby area and they formed new villages called Krasnyi Iar in 1634 and then Pokrovskoe in the 1650s and a number of smaller settlements called Osinovka, Burunovo, Iaroslavovo, Bazhenovo, etc. These large villages and smaller settlements were all formed on the Bashkir lands and the settlers had rented these lands from Bashkirs for short and long term with permission. They also seized some surrounding Bashkir lands freely, declaring them wild fields which belonged to no one. ${ }^{25}$

I. K. Kirilov reported that during the initial period of Russian colonization in the lands surrounding Ufa there were only 193 Russian people. The Bashkir lands, fishing rights and forest uses (beekeeping) were distributed by the government among the pomeshchiki, lesser nobles who had to serve in the army, and Cossack cavalry units more or less freely. ${ }^{26}$

The number of non-Russian settlers who accompanied Russian colonizers was higher than those of Russian settlers. According to the Iasak Inventory (Iasachnoi Oklad) of 1631 and 1632 they numbered around $8355 .{ }^{27}$ These people were mainly farmers and generally settled in Osinsk Doroga (northern parts of Bashkiria). Some of them occupied Bashkir lands with no previous arrangement and against the will of the Russian authorities and Bashkirs. This occupation took place relatively easily because at this period their number was small and free land was abundant. However some of the other newcomers who arrived in the region later had to make specific arrangements with the Bashkir communities and they made deals with them. Not

\footnotetext{
${ }^{25}$ U. Kh. Rakhmatullina, "Krest'ianskoe Zaselenie Bashkirii v 17-18 vv." in Krestianstvo i Krestianskoe Dvizhenie v Bashkirii v 17-Nachale 20 vv. ed. Kh. F. Usmanov, (Ufa: 1981), 9.

${ }^{26}$ Materialy po Istorii Bashkirskoi ASSR, v. 3, (Moskva \& Leningrad: Izdatel'stvo Akademii Nauk, 1949), 493.

${ }^{27}$ Materialy po Istorii Bashkirskoi ASSR, v. 4, part 1: Ekonomicheskie Sotsial'nye Otnosheniia v Bashkirii i Upravlenie Orenburgskim Kraem v 50-7--kh Godakh 18 v., (Moskva: Izdatel'stvo Akademii Nauk, 1956), 430; The authors of Ocherki Po Istorii Bashkirskoi Istorii argue that these 8355 households were composed of Teptiars and Bobyls. N. G. Ustiugov, et.al., Ocherki po Istorii Bashkirskoi ASSR, v. 1, part 1, (Ufa: Bashkirskoe Knizhnoe Izdatel'stvo, 1956), 97.
} 
surprisingly these types of settlements took place around the end of the 1640 s when the amount of free land was diminishing. ${ }^{28}$

On the other hand the Russian government was determined to bar non-Russian migrants from settling in Bashkir lands. The 1649 Law code relating to Bashkir lands was reconfirmed in a number of governmental decrees which strictly ordered Russian officials to take necessary measures. An order by the government to the voevoda of Ufa, F. I. Somov, in 1664 clearly stated that the voevoda must implement "the order strictly on Bashkirs of all four dorogas and Isetsk volost. The sale of the Bashkir votchina lands to Russians, Tatars, Chuvash and Cheremis was prohibited and no facility must be provided to these migrants in Bashkiria in the sectors relating to Bashkir economy like beekeeping and the quitrent between Bashkirs and these peoples must be prevented in order to avoid future conflicts." But Bashkirs could give their lands in quitrent to other Bashkirs for periods no longer than a year or two. The voevoda must strictly consider, the order continued, that "in Ufa no Russian servicemen or city people (zhilitskie liudi) or any kind of people of various ranks must conclude any written contract, neither mortgage nor bondage (kabaly), with the Bashkirs about the Bashkir lands and beekeeping lands.",29

From this document we have two clear conclusions. The first one is that not all Bashkirs were nomads. Some of them were full time peasants who rented the lands of non-agricultural Bashkirs. But the government limited rentals to a short period for fear of causing troubles in Bashkiria arising from the property problems pertaining to the land because in the long run the renters could start to consider these lands as their own. On the other hand the issue of land

\footnotetext{
${ }^{28}$ N. F. Demidova, “Zemlevladenie i Zemle polzol'zovanie v Ufimskom Uezde v 16-17 vv.” in Ezhegodnik po Agrarnoi Istorii Vostochnoi Evropy 1962 g. (Minsk: Izdatel'stvo Nauka i Tekhnika, 1964), 269

${ }^{29}$ A. I. Akmanov, Zemelnaia Politika Tsarskogo Pravitelstva v Bashkirii Vtoraia Polovina 16-Nachalo 20 vv. (Ufa: Kitap, 2000), 13.
} 
rentals in Bashkiria at the time is evidence that even the nomadic Bashkirs started to consider land as property which could belong to an individual. Earlier, in the late sixteenth century, nomadic Bashkir tradition held that the land belonged to the community and could not be owned. If individuals could rent the land now it could be owned individually as well.

Yet this and many other governmental orders failed to solve the migration problem in the region. Russian and non-Russian peasants continued to migrate to the region and through the region to areas further east despite increasingly stricter governmental interventions. In the first quarter of the eighteenth century the government was now operating in a mobile form through frontier guards (Karauly) to capture fugitives and establishing outposts to detect them along their tracks of flight. ${ }^{30}$

The flight of peoples to Bashkiria could not be halted by military measures. The peoples of the Middle Volga region were running away because of the Russian policies in their native region. In Kazan region in the years following the fall of Kazan, at least 1.5 million desiatinas of lands were seized by Russian nobles, pushing the indigenous people to the worst quality land or making them totally landless. ${ }^{31}$ In the Chuvash lands of the region Chuvash people were categorically expelled from their lands and many Chuvash people were reduced to serf status (krepostnicheskie poriadki). ${ }^{32}$

While in many cases the government tolerated violation of Bashkirs' votchina rights, more generally the government and its officials tried to respect those rights well into the eighteenth century. They did this to avoid provoking Bashkir rebellions, especially given the

\footnotetext{
${ }^{30}$ E. I. Zaozerskaia, "Begstvo i Otkhod Krest'ian v Pervoi Polovine XVIII Veka” in K Voprosu o Pervonachal'nom Nakoplenii v Rossii (XVII-XVIII vv.), (Moskva: Izdatel'stvo Akademii Nauk SSSR, 1958), 168

${ }^{31}$ A. N. Grigorev, "Khristianizatsiia Nerusskikh Narodnostei, kak Odin iz Metodov Natsional'no-Kolonial'noi Politiki v Tatarii (Polovina 16 v. do Fevralia 1917 g." in Materialy po Istorii Tatarii, 1. (Kazan: 1948), 227.

${ }^{32}$ M. N. Tikhomirov, "Prisoedinenie Chuvashii k Rossii" in Materialy po Istorii Chuvashkoi ASSR. 1. (Cheboksary, 1958), 127.
} 
Russian military weakness in the region. The Russian military in Bashkiria throughout the seventeenth and first quarter of the eighteenth century was weak and there were very few Russian troops in the region. A significant part of the Russian military force was composed of Cossacks. While very effective under strict discipline, they were not thoroughly reliable. As a result Russian policy in Bashkiria could be called one of appeasement. In 1728, the Supreme Secret Council (Verkhovnyi Tainyi Sovet) instructed the new voevoda of Ufa that local Bashkirs be treated gently in order not to cause any unnecessary resentment among Bashkirs and his subordinates be tactful when they were among Bashkirs and respect their customs. ${ }^{33}$ A decree by the Senate on 27 July 1731 ordered that the new Trans-Kama defensive line be constructed in places where Bashkirs did not occupy land. ${ }^{34}$ Another Russian sensitivity about the issues of Bashkir votchina rights came around the same time when there emerged a need to construct factories in the Urals. V. I. Tatishchev was sent to the Urals as the chief director of the Urals metal industry with full powers of a governor. ${ }^{35}$ The Senate decree promoting him to this position instructed him to pay attention to the land rights of Bashkirs while inspecting already available factories in the region and establishing new ones. ${ }^{36}$

There were already a number of Russian factories (mostly foundries) in the region whose history dates back to the 1630 s when the first copper works were founded along one of the tributaries of Kama by Nedei Sveteshnikov, one of the leading merchants of his time. In the $1660 \mathrm{~s}$, when the Russian entrepreneurs requested government's permissions, they were granted rights to establish iron works in the Urals. ${ }^{37}$ So when the state needs were considered primary

\footnotetext{
${ }^{33}$ Sbornik Imperatorskogo Russkago Istoricheskago Obshchestva, 84, (1893), 176.

${ }^{34}$ PSZ T.8 No: 5808

${ }^{35}$ Rudolph L. Daniels, V. N. Tatishchev: Guardian of the Petrine Revolution, (Philadelphia: Franklin Publishing Company, 1973), 50

${ }^{36}$ PSZ T. 9 No: 6559. This decree was reinforced in 31 May 1734 in another imperial ukaz PSZ T.9 No: 6581

${ }^{37}$ Joseph T. Fuhrmann, The Origins Capitalism in Russia: Industry and Progress in the 16-17th Centuries, (Chicago: Quadrangle Books, 1972), 137
} 
importance, the authorities did ignore the natives' reaction in the $1600 \mathrm{~s}$. Under Peter the Great new foundries were established in the early eighteenth century: Nev'ianskii (1701), Alapaevskii (1704), Kamenskii (1701), Uktuskii (1704). ${ }^{38}$ V. I. Tatishchev was one of the most brilliant Russian scholars of his time, a polymath and an avid supporter of Peter the Great's imperial vision and had great designs for the region. He envisaged making it an industrial zone of the Russian empire to exploit the immense underground riches of the region. The industrial potential of the region was enormous; low hills, vast forests for firewood, cold climate and huge distances where factories could be established. The greatest problem for the beginning of the industrialization of the region was the low population density and unsuitability of Bashkirs for factory work.

The construction of factories required an increasing flow of migrants to the region. Tatishchev as a pragmatic administrator against the orders of the Senate prevented the expulsion of Old Believers from the Ural region who were mostly working in the factories and enlisted them in the factories as legal workers. ${ }^{39}$

But the full exploitation of the region's riches required more people to man the garrison towns and to create a work force for the factories. A transfer of agrarian population from the European parts of the Russia and middle Volga region was needed to feed the rising population. ${ }^{40}$ In fact for the most part of the 1730s and the 1740s Russian and non-Russian populations in the region were increasing and adding fuel to the already fervent ethnic tension in the region.

\footnotetext{
${ }^{38}$ Zh. V. Drobnaia, "Ural'skie Goroda-Zavody kak Osnova Ekonomicheskogo Mogushchestva Rossiiskogo Gosudarstva v 18 v." Vtorye Tatishchevskie Chteniia, (1999), 52; E. Koutaissoff, "The Ural metal Industry in the Eighteenth Century" The Economic History Review, New Series, v. 4, no: 2 (1951), 253.

${ }^{39}$ Rudolph L. Daniels, V. N. Tatishchev: Guardian of the Petrine Revolution, (Philadelphia: Franklin Publishing Company, 1973), 56

${ }^{40}$ A. Z. Asfandiiarov, Bashkiriia posle Vkhozhdeniia v Sostav Rossii (Vtoraia Polovina 16 - Pervaia Polovina 19 v.), (Ufa: Kitap, 2006), 84-85.
} 
The most vivid period of factory foundation in Bashkiria was between 1740 and 1762 when Russian authorities became fully convinced that Bashkirs would no longer pose a threat to the tranquility of the region. I. I. Nepliuev's energetic and tactful policies as the governor of Orenburg Gubernia between 1744 and 1758 paved the way for industrialization of the region at a quickening pace. His term witnessed the peak of industrialization of the region. His real task was to restore economy of the region on a healthy ground, in this context bringing industry to the region to exploit the potential of the region to the fullest. ${ }^{41}$ Yet, data about the worker population reveals that the region was far from fully industrialized because as late as 1859 the total number of factory workers was only 96,100 out of a population of 1,977,000 in Orenburg. ${ }^{42}$

Then why did many Bashkir rebels attack these factories and blame them as one of the principal reasons for their rebellions? For one thing their foundation and survival required rounding up of large tracts of land and felling huge areas of forest for lumber and firewood. While the government used state lands in Bashkiria for those factories, private entrepreneurs simply invaded Bashkirs' votchina lands. Each factory used an area of at least 30 desiatins of land and surrounding forests which very effectively harmed the Bashkirs' economy, barring them from crossing these factory lands with their herds and using forests for beekeeping. ${ }^{43}$ It must be stated that these factories were founded near fortresses which themselves also covered large areas and with these consolidated factory-fortress lands Bashkirs were twice surrounded and their free movement was twice difficult. In the final analysis the total amount of land

\footnotetext{
${ }^{41}$ Roger Portal, “Industrializatsiia Iuzhnogo Urala 1745-1762 Gody” Vatandash, 9. (2002)

${ }^{42}$ G. F. Gudkov, Iz Istorii Iuzhnoural'skikh Gornykh Zavodov 18-19 Vekov, (Ufa: Bashkirskoe Knizhnoe Izdatel'stvo, 1985), 18.

${ }^{43}$ M. N. Martynov, Gornozavodskaia Promyshlennost na Urale Pri Petre I, (Sverdlovsk: Sverdlovskoe Oblastnoe Gosudarstvennoe Izdatel'stvo, 1945), 56; I. G. Akmanov, Bashkiriia v Sostave Rossiiskogo Gosudarstva 17-Pervoi Polovine 18 Veka (Sverdlovsk: Izdatel'stvo Ural'skogo Universiteta, 1991), 49
} 
seized/used by factories at the end of the 1760 s was about 3,079,837 desiatin, 9.1 percent of all Orenburg territory and 18.1 percent of all Bashkir votchina lands. ${ }^{44}$

\section{Relations between Natives and Migrants}

Increasing governmental control in the long run had transforming effects on Bashkirs because inter-cultural contacts accelerated as the newcomers (both Russian officials and settlers, Russian or non-Russian) induced Bashkirs to adopt a sedentary life. Neither Russian brutality during the times of the rebellions nor the Russian policy of non-interference played any such positive role. The colonization made intercultural exchanges possible and it became clear that the frontier region with the arrival of so many colonists by the second half of the eighteenth century turned out to be a "middle ground." Richard White argues that in the middle ground two distinct cultures meet and affect each other. Neither the indigenous people nor the newcomers have to be assimilated into each other's culture. Both cultures initially were radically different. Hence "they had to arrive at some common conception of suitable ways of acting; they had to create what I have already referred to as a middle ground." 45

Unlike Richard White's middle ground where only two groups (French and Algonquians) interacted, in the Bashkir case there were several different groups, Russians, Bashkirs, Tatars, Mishars, Chuvash, and a number of Finnish groups like Maris, Udmurts, Votiaks and even Komi Permiaks. ${ }^{46}$ There was even a wider gap within the Bashkir community between three groups: sedentary, semi nomadic and fully nomadic.

\footnotetext{
${ }^{44}$ U. Kh. Rakhmatullin, Naselenie Bashkirii v 17-18 vv: Voprosy Formirovanie Nebashkirskogo Naselenia, (Moskva: Nauka, 1988), 75

${ }^{45}$ Richard White, The Middle Ground; Indians, Empires and Republics in the Great Lakes Region, 1650-1815 (Cambridge: Cambridge University Press, 1991), 50.

${ }^{46}$ V. A. Oborin, "Migratsiia Mestnogo Naseleniia i ikh Rol v Osvoenii Urala v 16-17 vv." Istoriia USSR, v. 4, (1974), 69.
} 
The existence of such diverse groups and interethnic tensions notwithstanding, colonization formed a bridge that conveyed different cultural values to the Bashkirs, many of whom were still, even if partly, nomadic. It was the bridge which in the long run enabled Bashkirs to survive against the inexorable incursions of alien cultures. As mentioned above, the middle ground in Bashkiria was much more complex than in Richard White's colonial America because of the fact that Bashkirs had to deal with already repressed peoples by the Russian state in middle Volga. The Bashkirs' relations with these peoples, excepting Finnish groups, were quite complicated because they shared the same ethnic, linguistic background with Bashkirs and they could easily form marriage alliances and other contacts with them. But their relations remained tense for a very long time. Then fugitive Russian peasants arrived in the region in ever increasing numbers, and Bashkirs had nothing in common with them. Their influence on Bashkirs was minimal because of the cultural, linguistic and religious obstacles. Finally the Russian state appeared in the region with full force and crushed Bashkir resistance in all military forms. But the Russian armies' belated arrival in the region failed to solve the eternal Bashkir problem in the region due to the fact that Bashkirs remained an exclusive ethnic group.

The process of creation of a sedentary and agricultural society did not take place at the same level in every Bashkir district. Those Bashkirs who adapted themselves to the new economic conditions were the ones who lived in the northwestern districts of the region where cross cultural encounter took place in a more amicable environment thanks to the availability of a large group of ethno-culturally identical people. In the southern and eastern parts of the region non-Russian peoples were in short supply and Bashkirs' only contact with the intruders took place with the Russian officials, soldiers and Cossacks who were more alien to the culture of Bashkirs. These parts of Bashkiria resisted fiercely the new conditions and the central authority 
in these areas was consolidated only after a century of interethnic fighting, as discussed in previous chapters.

While in the early stages of Russian presence in the region the conflicts were solved to the benefit of Bashkirs, as of the 1640s Votchina rights of Bashkirs were increasingly violated both by the central and local administration. In this context for example the conflict between Bashkirs and Savvo-Storozhevsk Monastery over the fishing rights in Kama and Belaia Rivers was solved in favor of the Monastery which in fact exacerbated the crisis. ${ }^{47}$ While the fishing rights for the monastery did not constitute a big part of the revenues of the monastery, it was a vital part of the tribal and semi nomadic Bashkir society. Its loss could not be supplemented with agricultural production at this stage.

During this stage the Bashkirs found it difficult to start agriculture for some practical reasons. In a tribal nomadic society agricultural activity may exist but its scope is limited because they collectively own the land and have a very limited division of labor. ${ }^{48}$ If there is a rich natural food supply as was the case for the Bashkir tribal communities, the process towards sedentarization and agricultural life is even more difficult. In such a case only the outside interference of a superior force could make them settle down and look for their livelihood from the tilled lands. So the Russian governmental intrusion into the nomadic economy forced Bashkirs to search for other ways to survive.

There is another dimension in the sedentarization process as well. Even if a tribal community settles down it is not easy to abandon nomadic ways immediately. For the most part of the early years of the sedentarization the tribal customs and ways were preserved and

\footnotetext{
${ }^{47}$ N. F. Demidova, “Zemlevladenie i Zemle polzol'zovanie v Ufimskom Uezde v 16-17 vv." in Ezhegodnik po Agrarnoi Istorii Vostochnoi Evropy 1962 g.(Minsk: Izdatel'stvo Nauka i Tekhnika, 1964), 270.

${ }^{48}$ Åke E. Andersson, William Peter Anderson, Börje Johansson, The Economics of Disappearing Distance, (Ashgate: Aldershot Hampshire England;;Burlington VT ,2003), 197.
} 
nomadism turned out to be a part-time life style for the most Bashkirs. Since they were new settlers their inexperience in agriculture was clear and in order not to face starvation they did their best to preserve their nomadic ways to a great degree. In fact for many other tribal societies this was the norm. ${ }^{49}$

On the other hand these difficulties experienced by Bashkirs in passing to sedentarization were not universal. Fighting among Bashkirs over farmland indicated that some Bashkir groups were well advanced in their agricultural lives. For example in 1675 two Bashkir groups of Eneiskoi Volost of Kazan Doroga clashed over 30 polos (strips) of pashni (ploughed field). Bashkirs of another volost in the 1690s were complaining about crop failure. In Gireiskoi volost of Kazan Doroga, it is recorded that Bashkirs were operating two types of mills: Mel'nitsamutovka (whisk) and Mel'nitsa-Koleschataia (wheel). The latter one was constructed by Bashkirs. Their relations in this respect with the newcomers were increasingly determined by their insistence on agricultural economy. Bashkirs of Karshynskii volost allowed a number of Chuvash people to farm in their votchina lands on the condition that Chuvash tenants would have to construct a mill. ${ }^{50}$ On the other hand it must be noted that these Bashkirs groups were mainly from Kazan Doroga where sedentarization of Bashkirs was more widespread than among the Bashkirs of Sibir and Nogai Dorogas.

\footnotetext{
${ }^{49}$ Fatemeh E. Moghadam, From Land Reform to Revolution: The Political Economy of Agricultural Development in Iran, 1962-1979, (London ; New York : Tauris Academic Studies, 1996), 17.

${ }^{50}$ I. G. Akmanov, "Razvitie Zemledeliia u Bashkir v Pervye Veka Posle Prisoedineniia k Rossii i Politika Tsarskogo Pravitelstva po Zemelnomu Voprosu" in XXVI S'ezd KPSS i Problemy Agrarnoi Istorii SSSR (Sotsial'no-

Politicheskoe Razvitie Derevni), (Ufa: Bashkirskoe Knizhnoe Izdatel'stvo, 1984), 476
} 


\section{Changing Status and Conditions of Bashkirs}

The transition from semi-nomadism to sedentary form of life in Bashkiria was a long process which lasted from the mid-1500s to the first quarter of the twentieth century. ${ }^{51}$ When the Russians first appeared in Bashkiria what they found was a tribal society with different modes of economic life. Bashkirs who lived mostly in the regions adjacent to the former Kazan khanate were predominantly sedentary. In one account from a Bashkir elder from Gaininsk volost of Osin Doroga, those Bashkirs who lived in Nogai and Sibir dorogas were mostly nomadic and semi-nomadic. Since they had to drive their herds from pasturelands to other pasturelands on a seasonal base, the Russian defensive lines, which restricted their migration, hurt them most. Not surprisingly, these nomadic Bashkirs were the ones who in fact most fiercely fought against the Russian authorities throughout the seventeenth century and well into the eighteenth century.

\footnotetext{
${ }^{51}$ I. G. Akmanov, "Razvitie Zemledeliia u Bashkir v Pervye Veka Posle Prisoedineniia k Rossii i Politika Tsarskogo Pravitelstva pom Zemelnomu Voprosu" in XXVI S'ezd KPSS i Problemy Agrarnoi Istorii SSSR (Sotsial'noPoliticheskoe Razvitie Derevni), (Ufa: Bashkirskoe Knizhnoe Izdatel'stvo, 1984), 476.
} 


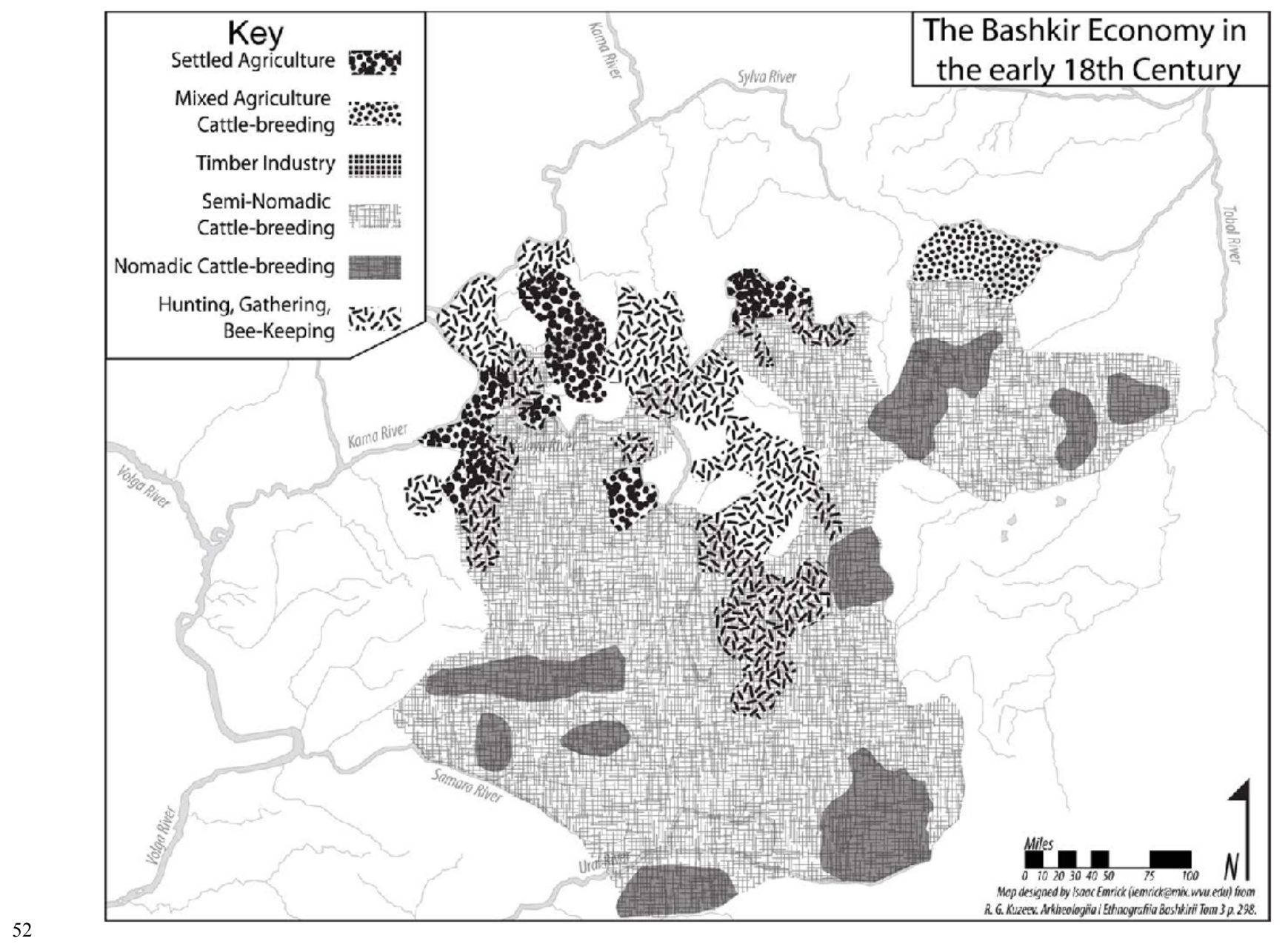

The turning point for the history of the region and the fate of the Bashkirs was the

Orenburg expedition of 1734 and the foundation of the Orenburg defensive line and the town of

Orenburg with many other smaller ones as initially garrison centers and then small towns as of

1734. Willard Sunderland argues that the Orenburg expedition was the clearest expression of the new (Russian) imperialism, which was a product of Petrine thinking which he calls

"scientifically inspired mercantilist imperialism." $" 53$ Even though the project's architect, I. K.

\footnotetext{
${ }^{52}$ R. G. Kuzeev, ed. Arkheologiia i Etnografiia Bashkirii, 3 (Ufa: 1968), 288

${ }^{53}$ Willard Sunderland, Taming the Wild Field: Colonization and Empire on the Russian Steppe (Ithaca, N.Y.:

Cornell University Press, 2004), 46; The literature about Orenburg Expedition in Russian abounds. I. G. Akmanov, "Iz Istorii Orenburgskoi Ekspeditsii" in Ocherki Istorii Dorevoliutsionnoi Rossii,v.1 ed. R. V. Filippov (Ufa: Bashkirskii Gos. Universitet, 1972); I. G. Akmanov, "Organizatsiia Orenburgskoi Ekspeditsii i Nachalo Vosstaniia 1735-1740 godov" in Ocherki Istorii Dorevoliutsionnoi Rossii v. 2 ed. R. V. Filippov (Ufa: Bashkirskii Gos.
} 
Kirilov, expressed his goals of reaching India in the final analysis, the main goal of the project was to open the vast and idle Bashkir steppe region to colonization and exploitation of the riches of the region. This plan required massive migration of farmers to the region to populate it. Empress Anna put it that "firstly it is needed that the city be populated by the settlers and its inhabitants be provided funding so that new trades may spring up and economic life develop and more and more people may settle down....,54

The destruction caused by the 1735-1740 war had to be repaired, a task which fell to Nepliuev. If careers of the governors of the region were taken into account it will be noticed that the governors of Orenburg Gubernia were by and large from the highest administrative and intellectual elite of the imperial Russian system. Though not a governor of the Orenburg region but the architect of Orenburg project, I. K. Kirilov was a distinguished scholar graduated from the Petrine school. He was also a brilliant geographer and a senior secretary of the Senate. ${ }^{55}$ His successor Tatishchev, as noted earlier, was a polymath and father of modern history writing in Russia. Nepliuev was also a leading Russian politician who suffered disgrace when his mighty patron Count Biron was toppled down in political struggle. Nepliuev was sent to Orenburg as governor which was in a sense a demotion but he turned out to be the true founder of Orenburg gubernia when he finally moved the city to its current location in $1744 .^{56}$

Universitet, 1975); Salavat U. Taimasov, "Rol' Orenburgskoi Ekspeditsii v Prisoedinenii Bashkirii k Rossii (1730-e gg.)" Voprosy Istorii, 2 (2008); Iurii Smirnov, Orenburgskaia Ekspeditsiia i Prisoedinenia Zavolzhia k Rossii v 3040-e gg 18 Veka,(Samara: Samara University, 1997); Iurii Smirnov, "Deiatel'nost' Orenburgskoi Ekspeditsii pod Rukovodstvom I. K. Kirilova v Zavolzh'e” Samarskii Zemskii Sbornik, 3 (1996); In the West Alton Donnelly mainly studied Orenburg area and Bashkir question in the eighteenth century. Alton Donnelly, The Orenburg Expedition: Russian Colonial Policies on the Southeastern Frontier, 1734-1740" (PhD diss., University of California, 1960); Alton Donnelly, The Russian Conquest of Bashkiria, 1552-1740: A Case Study in Imperialism, (New Haven and London: Yale University Press, 1968)

${ }^{54}$ PSZ. Tom 9 No; 6576; Anna I. Poterpeeva \& V. E. Chetin, Revoliutsionnaia Trudovaia Letopis Iuzhnoural'skogo Kraia; Khrestomatiia Arkhivnykh Dokumentov po Istorii Iuzhnogo Urala, 1682-1918, (Cheliabinsk : IuzhnoUral'skoe Knizhnoe Izdatel'stvo, 1980), 14.

${ }^{55}$ Orcutt William Frost, Bering: The Russian Discovery of America, (New Haven: Yale University Press, 2003$), 65$.

${ }^{56} \mathrm{He}$ founded Orenburg from scratch. From 1744 to 1747,840 houses, four churches and a number of governmental offices were constructed for which thousands of Bashkirs and Teptiars were recruited and they were paid 2.5 kopek 
Under his governance full colonization of the region started. His predecessors had founded many fortresses and sealed the fate of the region. From 1735 to 1758 , the number of fortresses constructed was 58 and 21 of these were constructed under Kirilov's administration from 1735 to $1737 .^{57}$ Such a complex web of fortification brought all Bashkir hopes of autonomy and nomadic life to an end. In a report to Senate in 1740, Orenburg Governor V. A. Urusov wrote that each fortress directly controlled an area of 10 to 12 versts in all directions and lands beyond these distances were now available for colonization. ${ }^{58}$ Accordingly the availability of such a complex fortification system enabled the migrants to populate these lands surrounding the fortresses.

To make matters worse for Bashkirs relating to land issue, the Russian government authorized the sale of Bashkir lands or their distribution to officials, soldiers and officers in a much-debated law of 11 February 1736, which was also a turning point for the Bashkirs. This law distributed land to several different groups of people varied group of people. According to the law, retired officers received between 50 and 100 chetverts, retired soldiers, dragoons and sailors received from 20 to 30 chetverts, Mishar elders were given up to 200 chetverts and ordinary Mishars received 50 chetverts of land. The sale of land was allowed in such a way that all the previous laws of the center and decrees of the voevodas were annulled and those who were willing to, were allowed to buy Bashkir lands. ${ }^{59}$

However this permission to trade turned out to be a rapacious pillaging of the lands of Bashkirs who after long years of fighting against Russian armies and their local agents and being

per day. He also authorized the foundation of a mosque near Orenburg by Tatar while hundreds of mosques were destroyed in Middle Volga region. This religious tolerance shows his pragmatism and determination to make Orenburg an important imperial provincial center. See; V. G. Semionov and V. P. Semiovna, Gubernatory Orenburgskogo Kraia (Orenburg: Orenburgskoe Knizhnoe Izdatel'stvo, 1999). 52.

${ }^{57}$ I. G. Akmanov, ed., Istoriia Bashkortostana s Drevneishikh Vremen do Nashikh Dnei v Dvukh Tomakh, v. 1, (Ufa: Kitap, 2007), 219.

${ }^{58}$ Materialy po Istorii Bashkirskoi ASSR, v. 3, (Moskva \& Leningrad: Izdatel'stvo Akademii Nauk, 1949), 502.

${ }^{59}$ PSZ Tom 9 No: 6890; PSZ Tom 11 No: 8623 
decimated were helpless to prevent the plunder. In one case a Russian official called R. Urazlin, a Tatar translator in the Orenburg Commission, seized a Bashkir, Ursai Baskunov, from IlkeiMinsk volost and forced him to abandon parts of his land. ${ }^{60}$ He also drew up a document in the Ufa Provincial chancellery which stated that above mentioned Bashkir had given his land for good to R. Urazlin and his offspring. Three years later in 1741, R. Urazlin arbitrarily arrested Baskunov and 10 other Bashkirs from the same volost and forced them before the voevoda to sign a document which stated that they sold their lands for 200 rubles. In fact such a payment never occurred. ${ }^{61}$ The amount of the Bashkir lands seized by Russians or non-Russians is not known for certain but it is clear that Bashkirs showered Russian authorities both in Ufa and in the capital with petitions complaining about unlawful seizures of their lands ${ }^{62}$

Nepliuev and his vice-governor P. D. Aksakov argued that the existing laws on the sale of the Bashkir lands had loopholes that produced highly undesirable results for the security of the region and could lead to another Bashkir rebellion. For this reason they proposed some adjustments. For example the sale of Bashkir land should be confirmed by the whole volost population rather than the individual Bashkirs or Bashkir starshinas. They also criticized and tried to persuade the central government to rescind the decree relating to the seizure of Bashkir

\footnotetext{
${ }^{60}$ Despite the arbitrariness and the corruption of the officials in the region in their relations with the Bashkirs, there were also a few exceptionally honest and upright ones as well. P. D. Aksakov was sharply different from the majority of the officials in the region. He vigorously struggled against the corrupt officials, like Seimanov, Tevkelev, Urazlin, Endarov, a leading Bashkir elder from Kazan doroga Sharyp Miakov etc. see; V. N. Vitevskii, I. N. Nepliuev i Orenburgskii Krai v Prezhnem Ego Sostave do 1758 g. (Kazan, 1897), 192.

${ }^{61}$ Materialy po Istorii Bashkirskoi ASSR, v. 3, (Moskva \& Leningrad: Izdatel'stvo Akademii Nauk, 1949), 389-391 and 513-514 see also Kh. F. Usmanov, ed. Istoriia Bashkortostana s Drevneishikh Vremen do 60-kh Godov $19 v$. (Ufa: Kitap, 1997), 227; Two years later the same Bashkirs petitioned the vice governor, P. D. Aksakov, about their victimization by Urazlin but nothing came of it.

${ }^{62}$ Kh. F. Usmanov, ed. Istoriia Bashkortostana s Drevneishikh Vremen do 60-kh Godov 19 v. (Ufa: Kitap, 1997), 227.
} 
horses as part of fine to be paid to the Russian government by the former Bashkir rebels who asked for forgiveness. ${ }^{63}$

In fact the seizure of Bashkir horses in the form of fines was one of the most direct reasons for the constant revival of Bashkir rebellion against the Russian government during the 1735-1740 Russo-Bashkir wars. As Mukhammed Eldashev, one of the Bashkir rebellious starshinas from Sibir Doroga relates the Russian government had left them no option but to revive the rebellion time and again. "Our Bashkirs again have started robbery since spring of this year because your Empress imposed heavy fines on people and horses...."64 This governmental effort to force Bashkirs to pay fines in horse had a quite detrimental effect on the Bashkir mobility and nomadic manners. With their horses gone, in an indirect way Bashkirs in fact were forced to abandon their nomadism and settle down.

Last but not least, Nepliuev and Aksakov moved against the governmental ban on the ironsmithery of Bashkirs arguing that the ban did not prevent Bashkirs from rebelling but on the other hand it had quite destructive results for the development of an agricultural economy within the Bashkir society. So they proposed to allow three ironsmiths for each Doroga for agricultural purposes. This would encourage Bashkirs to sedentarize. ${ }^{65}$ Nepliuev's long term goal for the Bashkirs was to strengthen them economically and thereby collect taxes. It would be a futile attempt to collect Iasak payments which Bashkirs had not paid for the last three years from 1737 to 1740 . Under the circumstances and after the devastating effects of the 1735-1740 Bashkir rebellion it was impossible to integrate them into the Russian system if they were pushed to the

\footnotetext{
${ }^{63}$ V. N. Vitevskii, I. N. Nepliuev i Orenburgskii Krai v Prezhnem Ego Sostave do 1758 g. (Kazan, 1897), 403-415.

${ }^{64}$ Materialy po Istorii Bashkirskoi Istorii, part 1, Bashkirskie Vosstaniia v 17 i Pervoi Polovine $18 v v$. (Moskva\&Leningrad: Izdatel'stvo Akademii Nauk SSSR, 1936), 325

${ }^{65}$ A. N. Usmanov, "Razvitie Zemledelie v Bashkiri v Tret'ei Chetverti 18 Veka" in Iz Istorii Feodalizma $i$ Kapitalizma v Bashkirii, ed., S. M. Vasil'ev and A. N. Usmanov, (Ufa: 1971), 25.
} 
brink of desperation. ${ }^{66}$ Their proposals were gradually accepted by the end of the eighteenth century.

The Muslim population also increased in the region by the 1740s. While the number of Muslims in the Trans-Kama region was about 220,000 according to the census of 1719 this number in 1744 was higher. Considering the fact that the Bashkir population suffered terribly from the Russo-Bashkir war of 1735-1740, this increase was largely due to the migration of Middle Volga Tatars to the region. Religious persecution of these Tatars gained momentum after the foundation of Office of New Converts (Kontora Novokreshchenskikh Del') on September 11, 1740 when Empress Anna issued an ukaz relating to the issue.

The physical attacks on Muslims started in 1741 and the subsequent increase of Tatar migration to Bashkiria was not within the jurisdiction of the Office of New Converts. This flight of Kazan Tatars was facilitated by the foundation of Orenburg Gubernia in 1744 and not coincidentally the officials in Orenburg invited Kazan Tatars to the region and exempted them from the obligations which were imposed on Tatars in Middle Volga. The most famous Tatar

\footnotetext{
${ }^{66}$ From 1734 to 1758 Orenburg project then Orenburg Gubernia was led by five Russian officials, I. M. Kirilov as head of Orenburg expedition, (1734-1737), V. N., Tatishchev as head of Orenburg Commission (1737-1739) V. A. Urusov as head of Orenburg Commission (1739-1741), L. Ia. Soimonov as head of Orenburg Commission (17411742) and finally I. I. Nepliuev as head of Orenburg Commission ( 1742-1744) and then Orenburg Gubernia (17441758) Of these five Russian officials only Tatishchev and Nepliuev seem to contribute something positive to the development of Bashkirs' situation. Kirilov was a westernized official, biased towards anything oriental accordingly he most possibly due to his obsession to succeed his Orenburg project adopted a stern policy against Bashkirs. Urusov and Soimonov are more obscure personalities who rose from the ranks and they were from the very beginning part of Orenburg project and worked under either Kirilov or Tatishchev. They both lacked Kirilov's scientific skills but imitated his hard-line policies believing that only further brutality could end Bashkir rebelliousness. Tatishchev and Nepliuev were the only ones who valued the potential of Bashkirs in Russian state's policy in the region. Though they knew how to be brutal, they followed a relatively lenient and more constructive policy towards Bashkirs. In their thinking, if Bashkirs could be sedentarized and converted into a farming society they could be pacified and integrated into the Russian system and lose their rebelliousness. See; Apollon Kuzmin, Tatishchev, (Moskva: Molodaia Gvardiia, 1981); Igor Shakino, Vasilii Tatishchev, (Sverdlovsk: Sredne-Ural'skoe Knizhnoe Izdatel'stvo, 1986); Iu. Tatishchev, K Istorii Upravleniia V,. N. Tatishchevym Orenburgskoi Ekspeditsii 1737-1739 gg,( Moskva: 1901); G. A. Mikhaleva, Torgovye i Posol'skie Sviazi Rossii so Sredne Aziatskami Khanstvami cherez Orenburg, (Vtoraia Polovina 18 - Pervaia Polovina 19v. ), (Tashkent: Izdatel'stvo FAN Uzbekskoi SSSR, 1982); Iu. N. Smirnov, "Deiatel'nost' Orenburgskoi Ekspeditsii pod Rukovodstvom I. K. Kirilova v Zavolzh'e” Samarskii Zemskii Sbornik, 3, (1996); M. G. Novlianskaia, Ivan Ivanovich Kirilov, Geograf 18 Veka,(Moskva-Leningrad: Nauka, 1964); V. G. Semyonov and V. P. Semyonova, Gubernatory Orenburgskogo Kraia, (Orenburg: Orenburgskoe Knizhnoe Izdatel'stvo, 1999)
} 
settlement which was established during this period was the village Kargala, not far away from the Orenburg town center. ${ }^{67}$ While in the 1740 s and the 1750s Muslim people of the Middle Volga region were under the pressure of the Office of New Converts and forcefully converted into Christianity, the Tatar Muslim migrants in Orenburg were spared from these pressures and granted freedom of conscience. ${ }^{68}$ These two seemingly contradictory policies actually provide an example of the way pragmatism won out over dogmatism in the Russian imperial system. The Russian military governor, I. I. Nepliuev was determined to populate Orenburg Gubernia and for this reason the best policy was to recognize freedom of conscience in order to attract migrants. On the other hand, Muslims of the Middle Volga region posed a potential threat to Moscow, the heart of Russia, because of the proximity of the region. So the authorities considered conversion as a necessary policy in the Middle Volga.

By the year 1744 the total number of Tatars in the region was more than 70,000. This high number could be attributed to the religious persecution in Middle Volga but it must be born in mind that Tatars in Bashkiria were service people under the imperial system. The Tatars of Orenburg numbered around 19,000 in $1719,73,000$ in 1744 and 87,000 in $1762 .{ }^{69}$ Bashkirs on the other hand were too backward to serve Russia's imperial needs in the region and further south. More educated and more urban Tatars could be used as intermediaries in Russians' relations with the central Asians.

One of these Tatars, Seit Khaialin, was a Tatar merchant from Kazan Gubernia and was

\footnotetext{
${ }^{67}$ It was founded as Kargala village but it was renamed Seitov Posad and given town status in 1784. PSZ volume 20, No; 16089

${ }^{68}$ For Nepliuev's colonization policy see N. N. Firsov, Dvukhsotletnei pamiati I.I. Nepliueva - riechi, (Kazan: 1894), 35-48

${ }^{69}$ Damir M. Iskhakov, Rasselenie i Chislennost' Tatar v Povolzhsko-Priural'skoi Istoriko-Etnograficheskoi Oblasti v 17-19vv. (Moskva: 1980), 33.
} 
potentially subject to religious persecution. ${ }^{70}$ The governor of Orenburg Gubernia, Ivan Nepliuev, determined to make Orenburg a springboard to move Russian influence and authority further southeast, deep into Central Asia, invited Khaialin and a number of Tatar families to establish the village Kargala (later called Seitovskii Posad) and immediately granted them freedom from the state-directed religious persecution that was taking place in the middle Volga region. $^{71}$ The foundation of Seitov Posad was prime example of Russian pragmatism in this context. In fact it is evidence that Russian religious policy in the empire lacked coordination and synchronism. $^{72}$

Seit Khaialin and his fellow Tatars were invited to region with issuance of a specific law. The Imperial Senate with the insistence of Governor Nepliuev issued this law on 8 March 1744, about the settlement of Kazan Tatars in Orenburg and their right to construct their masjids in their settlements. While the government actively sought the conversion of non-Orthodox population in parts of its empire, it simply out of necessity protected and served Muslims in other parts of the empire. The law clearly opened Bashkir lands (now fully within Orenburg Gubernia) to colonization, and even European farmers were invited to the region. This law marked de facto

\footnotetext{
${ }^{70}$ G. G. Kosach, Gorod na Styke Dvukh Kontinentov; Orenburgskoe Tatarskoe Menshinstvo i Gosudarstvo (Moskva: 1998), 31.

${ }^{71}$ These Tatars under Seit Khaialin numbered around two hundred households. However this number is contested because the 1747 census put it that there were only 170 families and the number of Tatar souls was 996. See; Edward J. Lazzerini, "Volga Tatars in Central Asia, $18^{\text {th }}-20^{\text {th }}$ Centuries: From Diaspora to Hegemony" in Central Asia in Historical Perspective, ed. Beatrice Manz (Boulder: Westview Press, 1994), 88; Other sources relating to the foundation of Seitov Posad are as follows; G. A. Mikhaleva, "Seitovskii Posad Orenburga i Ego Rol' v Razvitii Russko-Sredneaziatskii Torgovli” Obshchestvennye Nauki v Uzbekistane, 12 (1980), 39-42; Rashit Iskandarov, Seitov Posad: Ocherki po Istorii Orenburgskoi (Tatarskoi) Kargaly (Kazan: Tatarskoe Knizhnoe Izdatel'stvo, 2005); L. I. Futorianskii, Istoriia Orenburzhia, (Orenburg: Orenburgskoe Knizhnoe Izdatel'stvo, 1996), 33. ${ }^{72}$ For greater detail about Seitov posad see Edward Lazzerini, Volga Tatars in Central Asia 18-20 Centuries: From Diaspora to Hegemony, (Washington, D.C. : National Council for Soviet and East European Research, 1993), 6-7; Kornet Stepanov, "Kargala ili Seitovskii Posad" Russkii Arkhiv,11, Section 2 (1897), 602-609; G. A. Mikhaleva, "Seitovskii Posad Orenburga i Ego Rol' v Razvitii Russko-Sredenaziatskii Torgovli" Obshchestvennyi Nauki v Uzbekistane, v. 12, (1980), 39-42; Rashit Iskandarov, Seitov Posad Ocherki po Istorii Orenburgskoi (Tatarskoi) Kargaly (Kazan: Tatarskoe Knizhnoe Izdatel'stvo, 2005); Grigorii Kosach, “A Russian City between Two Continents: The Tatars of Orenburg and State Power" in Russia at a Crossroads: History, Memory and Political Practice,ed., Nurit Schleifman, (Frank Cass; London, 1998), 33-88.
} 
the end of the Bashkir votchina rights. The law attempted to make the region and the city of Orenburg in particular an attractive economic spot for various foreign nationalities (merchants, artisans, artists and other professional groups) who would make business in the region. Such people were expected to settle down, live, trade and perform their arts. ${ }^{73}$ This law was a very important one for the rest of the history of the region and the Bashkirs because with its issuance the road for colonization in Bashkiria became wide open. From the perspective of religion it is also a turning point for the Muslim peoples of the region.

The declaration of the central governments' intentions about colonization in the Bashkir lands so far kept hidden was evidence that the Bashkirs were no longer active inhabitants of their own lands where they had a right to stay in the past and oppose central government's decision in matters relating to their region. They were now reduced to the position of bystanders in Bashkiria as they desperately watched the migration of other national groups in to their lands. They had two options: fiercely rebelling and each time being crushed, which sometimes could mean extinction (the collaborationist Bashkir minority would be assimilated within the more dominant Muslim groups) or accommodating themselves to the new conditions and intercultural interactions that had begun long before. Available evidence proves that Bashkir groups having realized the benefits of an agricultural sector in the economic life of the region slowly started seeking ways to accommodate themselves to this new form of life and economy. A certain Bashkir called Nurkeika Emashev and a number of his Bashkir friends, from the Min tribe, sent a petition to the officials in Ufa in 1700 requesting that they needed "plowed fields, hayed meadows, forest, land transport with all means" since in their votchina "the city of Ufa was founded, inhabited by the grain producing Russians surrounded by Tatar villages."74

\footnotetext{
${ }^{73}$ PSZ volume 12 No: 8893

${ }^{74}$ R. Z. Ianguzin, Khoziaistvo Bashkir Dorevoliutsionnoi Rossii (Ufa: Bashkirskoe Knizhnoe Izdatel'stvo, 1989 ), 26.
} 
Apparently the foundation of the towns in the territory of Bashkirs and the influx of Russian officials and soldiers to the region created a lucrative food market. Under the influence of other nationalities and Russian peasants alike, the neighboring Bashkirs grew determined to get their share from this trade by becoming producers themselves. The market opportunities provided an incentive for Bashkirs to sedentarize and farm, and then in the long run, to be discussed in next chapter, it led to Islamization.

However, not all Bashkirs were as quick minded as Nurkeika Emashev and his friends, and most Bashkirs suffered from their lack of experience in dealing with the colonizers in the new economic era. Their lands were grabbed from them with no or ridiculously low payments and their slowly evaporating nomadic naivety caused their victimization in many instances. S. T. Aksakov relates occasions in Bashkiria where Bashkirs were fooled by the newcomers.

(After heavy drinking with the potential leasers,) "Casual remarks will follow about the boundless possessions of the Bashkirs, and of the scant reliance to be placed on leaseholders, who are ready enough to pay the ground rent for the first two or three years, and then will cease payment altogether, and refuse to quit the land, thereby forcing the Bashkirs into wearisome lawsuits, which, as often as not, are decided against the landlords.",75

Bashkirs were now facing a new world in which legal rights of an alien culture imposed on the Bashkirs brand new manners like defending their rights in the courtroom, dominated by the same alien culture. Land was not private property in the nomadic Bashkir society. Maybe at most the pasturelands were used commonly by the members of each clan which they fiercely defended in the past against the other Bashkir groups. This was what they understood from the notion of property. The crafty Russian landlord was adept at fooling the naïve Bashkir and persuaded him to sell his land whose limits were poorly defined. "Frequently whole districts are ${ }^{75}$ S. T. Aksakov, The Family Chronicle, (New York: E. P. Dutton \& Co., Inc., 1961), 4-5. 
purchased for trifling sums, and the purchase duly legalized by a formal deed, in which it is impossible to state the exact area of the land, as it has never been measured. Usually natural features of the land serve as boundaries. 'From the mouth of the Konlyelg rivulet as far as the withered birch tree beside the Path of the Wolf - and from the withered birch straight along to the Parting of the Waters - and thence to the Fox Holes, and so on.' Such accurate and incontestable boundaries would often enclose tracts of ten-twenty-even thirty thousand desiatinas. And for these vast properties a few hundred silver roubles were willingly accepted, not counting a hundred or so of roubles for the feast." ${ }^{, 76}$

So it is clear that Bashkirs, after being defeated in their wars against the Russian government, were also losing their lands to the newcomers who brought and imposed their own conditions, mentality and legal system into the region to which Bashkirs were alien. The Russian-Bashkir encounter resembled many interactions in other empires between naïve natives and cunning and greedy newcomers from more advanced European societies and for the most part, these encounters ended against the natives. The newcomers' ways of living, like excessive alcohol consumption, dramatically undermined the tribal and traditional way of life in most of the frontier societies. Alcohol and disease (in the Americas not in Bashkiria since Bashkirs had already developed their immunity against the known diseases) had always been a weapon of conquest in the frontier areas in South Africa or in the Americas. The Bashkirs unfortunately for themselves shared the fate of other frontier native peoples as Aksakov clearly put forth above. ${ }^{77}$

\footnotetext{
${ }^{76}$ S. T. Aksakov, The Family Chronicle, (New York: E. P. Dutton \& Co., Inc., 1961), 4-5.

${ }^{77}$ Eduardo Duran and Bonnie Duran, Native American Postcolonial Psychology (Albany: State University of New York Press, 1995), 138; C. A. M. Hennessy, The Frontier in Latin American History (Albuquerque: University of New Mexico Press, 1978), 148-149; Darshini Anna de Zoysa, The Great Sandy River: Class and Gender Transformation among Pioneer Settlers in Sri Lankas Frontier, (Amsterdam: Spinhuis, 1995), 384; Willard Sunderland also underlines the same theme adding that pioneer landlords like the Timashevs, Mansurovs, Ermolaevs and Krashennikovs bought huge tracts of lands at ridiculously low prices after they offered feasts and barrels of vodka to the Bashkir sellers. Willard Sunderland, Taming the Wild Field: Colonization and Empire on the Russian Steppe (Ithaca, N.Y.: Cornell University Press, 2004), 93.
} 
The Bashkir rebellious spirit was crippled by the end of the eighteenth century. There were several reasons for this. The Russian imperial system had firmly established itself in the region, leaving no room for maneuver to the Bashkirs. With the nearly complete pacification of Bashkirs, the region had already become a multinational region. For example the number of Tatars had grown to exceed that of Bashkirs, in several uezds of the region like Menzelinsk, Sarapulsk, Bugulminsk, Elabuzhsk. ${ }^{78}$

By the beginning of the nineteenth century, the demographic structure of Bashkiria had radically changed. At the beginning of the eighteenth century the majority of the population (more than 2/3) in the region was Bashkir. The 1719 census shows that share of Russians in the total population was 15 percent; the Tatar population was 13 percent. This picture was astonishingly different in the early 1800s. Russians were 37 percent, Tatars were 27 percent and Bashkirs were a minority now, 23 percent. $^{79}$ The total Muslim population was higher than the Russian one and by this time Bashkirs and Tatars had much more in common in their life styles because of the fact that Bashkirs to a great degree had been sedentarized and accordingly more Islamized. The flow of peoples into the region enabled Bashkirs to enter cross cultural encounters with their Middle Volga kinsmen. A significant amount of marriages (43 percent) by the end of the eighteenth century took place between Bashkirs and Teptiars. ${ }^{80}$

\footnotetext{
${ }^{78}$ Damir M. Iskhakov, Rasselenie i Chislennost' Tatar v Povolzhsko-Priural'skoi Istoriko-Etnograficheskoi Oblasti v 17-19vv. (Moskva: 1980), 29-30

${ }^{79}$ L. I. Futorianskii, Istoriia Orenburzhia (Orenburg: Orenburgskoe Knizhnoe Izdatel'stvo, 1996), 33; R. Z. Ianguzin also agrees with this demographic picture. He argues that one fourth of the population at the end of the Eighteenth century was Bashkir. However U. Kh, Rakhmatullin's figure for Bashkirs is significantly lower than that of both Ianguzin and Futorianskii. For him Bashkirs were only 19.08 percent of the total population of the region. See R. Z. Ianguzin, Khoziaistvo Bashkir Dorevoliutsionnoi Rossii, (Ufa: Bashkirskoe Knizhnoe Izdatel'stvo, 1989), 24; U. Kh. Rakhmatullin, Naselenie Bashkirii v 17-18 vv Voprosy Formirovanie Nebashkirskogo Naselenia (Moskva: Nauka, 1988), 187.

${ }^{80}$ Damir M. Iskhakov, Rasselenie i Chislennost' Tatar v Povolzhsko-Priural'skoi Istoriko-Etnograficheskoi Oblasti v 17-19vv. (Moskva: 1980), 30.
} 
The population of the region by the end of the eighteenth century had significantly increased thanks to the governmental policy of the colonization of the area. Even Bashkirs despite all their sufferings during the great age of rebellions against the Russian government recorded some natural growth. For U. Kh. Rakhmatullin the Bashkir population was approximately 110,000 in the 1730 s and the 1740 s and at the end of the century there were as many as 184,000 Bashkirs. Though it must be considered that during the same period the nonBashkir population had increased perhaps 6.6 times reaching to $577,300^{81}$ it is clear that Bashkirs nevertheless achieved a natural growth in demographic terms. Iu. M. Tarasov relates this natural growth to the success of the sedentarization of Bashkirs but he argues that the population of Bashkirs in 1794 was $212,000 .^{82}$

Under the circumstances it was clear that the former demographic density was much higher than a century earlier. The Orenburg defensive line had effectively surrounded Bashkir lands and factories and settlements of all types had mushroomed. Agricultural life dominated the countryside with fields everywhere in the region. So it is not difficult to assert that Bashkirs after being heavily pacified by Russian authorities had no other choice but to sedentarize. It is worth noting, however, that this sedentarization initially took the form of partial settlements.

The nomadic Bashkirs did not all of a sudden abandon their herds. The results of their rebellions against the Russian rule in the region were devastating materially. Their herds were driven away or after each rebellion was over they were fined to pay in kind to the authorities. So in time in parts of Bashkiria they were left with no herds and little land in their own hands.

\footnotetext{
${ }^{81}$ R. Z. Ianguzin, Khoziaistvo Bashkir Dorevoliutsionnoi Rossii (Ufa: Bashkirskoe Knizhnoe Izdatel'stvo, 1989 ), 23. ${ }^{8282}$ Iu. M. Tarasov, Russkaia Krest'ianskaia Kolonizatsiia Iuzhnogo Urala, Vtoraia polovina 18-Pervaia Polovina 19 v., (Nauka; Moskva, 1984), 61; The population of Bashkirs in the Eighteenth century cannot be measured with scientific exactitude due to the fact that Bashkirs did not take part in the censuses during this period, those authors who have claims about the number of Bashkir souls only rely on the Russian archival sources about the number of Bashkir households and assuming a certain number of members for each household. Salavat Taimasov, "O Chislennosti Bashkir, o Starshinakh i Tarkhanakh v Period Obrazovaniia Orenburgskoi Gubernii” Vatandash, (Oktiabr' 2006)
} 
So the number of animals declined significantly thanks to the both devastations caused by the rebellions and the impossibility of spending winters hundreds of miles to the south near Aral Sea because of Russian fortifications which hindered crossing the border. So in time the livestock grew thinner. In 1763 a leading Bashkir elder from the Nogai Doroga, Sel'tiasha Nurkuuev, reported to the governor of Orenburg, D. V. Volkov, "We are only not familiar with toiling in the fields very much. We have generally between 200 and 300 horses and 100 cows and not a few sheep." ${ }^{, 83}$ In the seventeenth century a rich Bashkir could have from 2 to 3 thousand horses on average, but in the mid-eighteenth century there was little need to keep large herds and in fact it was practically impossible. In the regions where agriculture had begun earlier and was more developed like Osinsk doroga, this radical shift towards sedentarization and abandonment of large herds was even more visible. Iukhnev relates that "All Bashkirs live in houses. They produce grain a lot and during the summer they do not go to the steppe but they stay in their houses like Russians. Their cattle are not many and just like others they mow hay a lot. They produce enough honey and wax." ${ }^{84}$

The famous Orenburg historian Petr I. Rychkov (1712-1775) who played a significant role during the early years of the Orenburg project and Orenburg Gubernia argued that the only way to solve the Bashkir crisis of the Russian empire and the only effective method to help Bashkirs was their sedentarization and the development of agriculture as the main economic force among them. He argued that Bashkirs had everything for a successful agricultural economy. The land was fertile; the climate was suitable; their draft animals, horses in particular were strong; abundant opportunities for hunting, a long-established Bashkir skill; they were also used to mowing grass and harvesting abundant hay to feed their animals during the winter time.

\footnotetext{
${ }^{83}$ Materialy po Istorii Bashkirskoi ASSR, v. 4, Part 2: Ekonomicheskie Sotsialnye Otnosheniia v Bashkirii $i$ Upravlenie Orenburgskim Kraem v 50-7--kh Godakh 18 v., (Moskva: Izdatel'stvo Akademii Nauk, 1956), 43-45

${ }^{84}$ Materialy po Istorii Bashkirskoi ASSR, v. 3, (Moskva \& Leningrad: Izdatel'stvo Akademii Nauk, 1949), 487
} 
Still they were accustomed by long tradition to pastoral life (skotovodstvo) and a fully agricultural life and working in the fields seemed to be backbreaking and hellish. So Rychkov warned caution against forcing these people to start new types of production like agriculture. Instead they had to be persuaded in time about the positive results of an agricultural life. To help them start agriculture and settle down, Bashkir elders could be used to convince Bashkirs because they had immense respect and trust for such individuals. ${ }^{85}$

The approximate estimate of the amount of the land seized by different social groups and for different purposes is huge but at any rate Bashkirs were left with adequate amounts of land for a successful agricultural economy. Until the 1820s in Orenburg Gubernia the total amount of land was 28.2 million desiatinas and 12.8 million desiatinas belonged to Bashkir votchinniks but 9.6 million desiatinas of these lands were tilled jointly with Bashkirs and pripushchenniks (any person who settled in Bashkiria with certain conditions). Nobles (dvoriane) and factory owners owned 3.6 million desiatinas of land while Russian peasants (state and udelnyi together) used 6.4 millions of desiatinas; service people enjoyed the ownership of 4 million desiatinas and finally 1.3 million desiatinas of land were owned by the state treasury. ${ }^{86}$

\footnotetext{
${ }^{85}$ M. M. Kul'sharipov, Politika Tsarizma v Bashkortostane (1775-1800 gg.), (Ufa; RIO BashGU, 2003), 27 ; S. I. Rudenko, Bashkiry: Istoriko-Etnograficheskie Ocherki (Moskva-Leningrad: Izdatel'stvo Akademii Nauk SSSR, 1955), 63; R. Z. Ianguzin, Etnografiia Bashkir (Ufa: Kitap. 2002), 26.

${ }^{86}$ For A. I. Akmanov's article about the landownership (Zemlevladenie) in Bashkiria see; I. G. Akmanov and Aznagul Uruskulov, ed, Bashkirskaia Entsiklopediia, v. 3 (Ufa: Nauchnoe Izdatel'stvo, 2005), 56. The author of the article used the following sources for his article. N. A. Chuloshnikov, "K Istorii Bashkirskogo Zemlevladeniia i Russkoi Pozemel'noi Politiki Posle Ukaza 1832 Goda” Trudy Orenburgskogo Obshchestva Izucheniia Kirgizskogo Kraia, Vypusk 1 (Orenburg: 1921); N. F. Demidova, "Zemlevladenie i Zemlepol'zovanie v Ufimskom Uezde 16-18 vv." Ezhegodnik po Agrarnoi Istorii Stran Vostochnoi Evropy, 1962, (Minsk: 1964); F. L. Shakurova, Bashkirskaia Volost' i Obshchina v Seredine 18 - v Pervoi Polovine 19 Veka, (Ufa, 1992); A. I. Akmanov, Bashkirskoe Zemlevladenie v 19 -Nachale 20 vv. (Ufa: 2000); A. I. Akmanov, "Voprosy Bashkirskogo Zemlevladenie v Materialakh Gosudarstvennoi Dumy, 1906-1917 gg. (po Vystupleniiam Musul'manskikh Deputatov)" (Unikal'nye Istochniki po Istorii Bashkortostana: Materialy II Period, Region. Nauch. Prakt. Konf. Ufa, 20 Dek. 2001)
} 


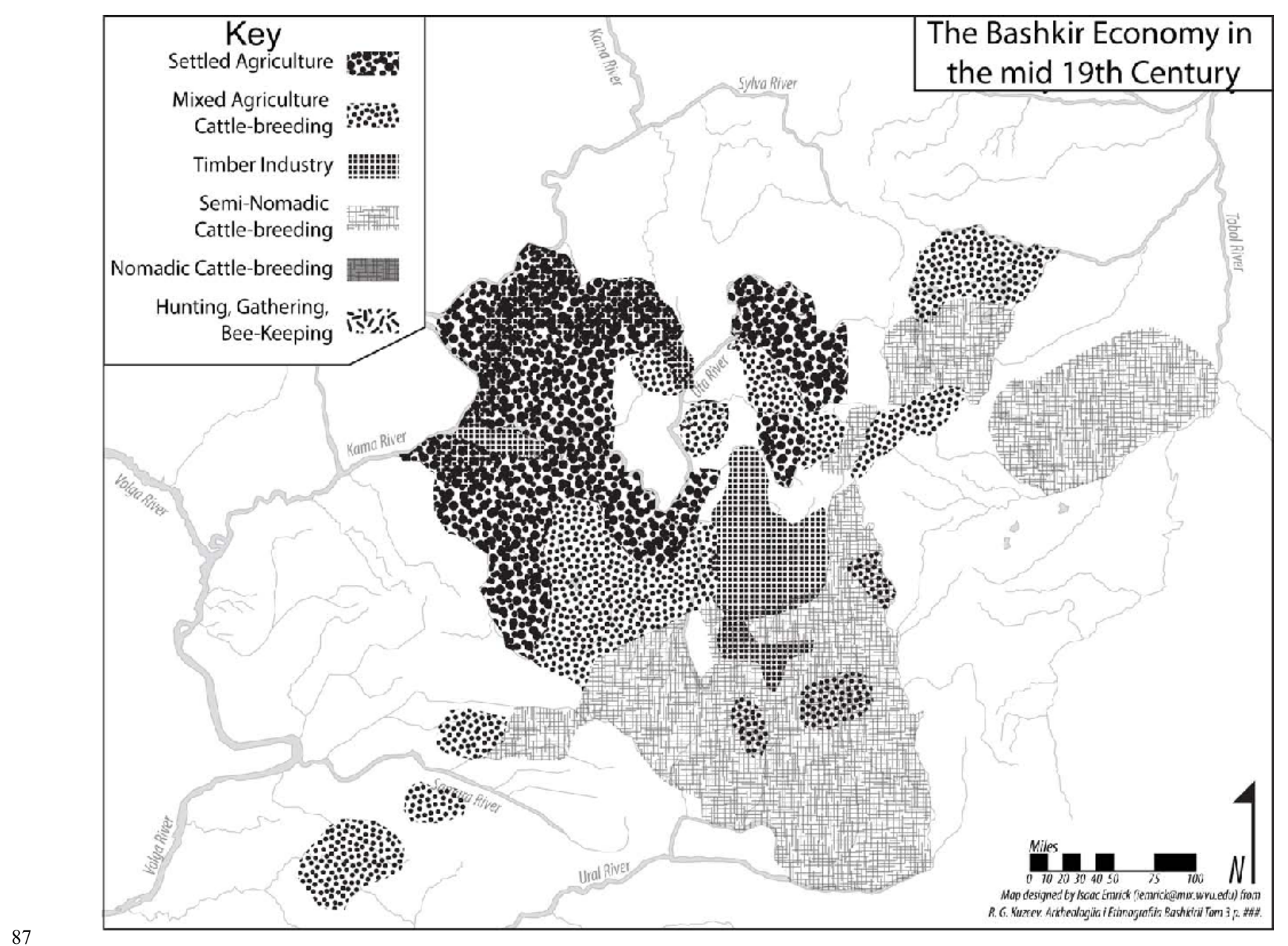

Russian nobles until the second half of the eighteenth century owned 8 percent of the arable land in Orenburg region. Individual Russian pomeshchiks had incredibly large latifundias. For example the Timashev family owned 212 thousand desiatinas of land in Birsk, Buguruslan, Orenburg and Ufa uezds. The Levashov family managed to round up 172,973 desiatinas of land in Menzelinsk, Verkhneuralsk and Sterlitamak uezds. The Kuroedov family owned 40,425 desiatin of land. The Osorgin family had 35,300. The Zubov family in different uezds had 43,272 desiatinas of land. The famous Aksakov family owned 35,300 desiatinas of land in four different uezds of Bashkiria. In total at the end of the second half of the eighteenth

${ }^{87}$ R. G. Kuzeev, ed. Arkheologiia i Etnografiia Bashkirii, 3 (Ufa: 1968), 298 
century the total amount of Bashkir lands controlled by the Russian nobles was 2,651,481 desiatinas. ${ }^{88}$ Comparison of the figures from the late 1700 s and the 1820 s shows that Russian nobles steadily enlarged their land ownership in Bashkiria. The distribution of the dvorian lands concentrated unevenly in the northern and western Bashkiria. Sixty-three percent of such lands were in those areas. The consolidation of dvorian lands was accompanied by the transfer of Russian serfs into the area.

Even though Bashkirs and their pripushchenniki (Teptiars, Bobyls and others) formed less than 40 percent of the total population of the region at the end of the eighteenth century they were nevertheless able to use 45 percent of the lands in Orenburg region. These lease holders after working under or for Bashkirs for a certain period of time refused to pay Iasak to Bashkirs or ceased to work under/for Bashkirs and grabbed the lands formerly owned by Bashkirs after the suppression of the Bashkir rebellions, or they simply claimed landownership of those lands they tilled against which Bashkirs could do nothing but sue them. ${ }^{89}$ These peaceful attempts to regain their grabbed lands could produce results only after years of legal struggle. Even then it was very uncertain that they could regain their lands since the Russian courts required Bashkirs to prove their ownership of land after presenting land grant given by the Russian officials and authorities since the time of Ivan the Terrible. Yet this was an impossible requirement to fulfill because most of the documents relating to the land grant had been lost during the previous Bashkir rebellions. So land ownership in Bashkiria changed hands permanently.

\footnotetext{
${ }^{88}$ U. Kh. Rakhmatullin, Naselenie Bashkirii v 17-18 vv Voprosy Formirovanie Nebashkirskogo Naselenia, (Moskva: Nauka, 1988), 66

${ }^{89}$ S. T. Aksakov, The Family Chronicle, (New York: E. P. Dutton \& Co., Inc., 1961), 8.
} 


\section{Conclusion}

The Russian government's policies developed from restraining migration to imposing it over the decades as Muscovy developed into Imperial Russia. Authorities followed a pragmatic policy in the region in terms of colonization and as their needs varied over time they showed a remarkable elasticity in their relations with the natives. The Russian governments' policy was not to allow Bashkir lands for individual colonization for the most part of the seventeenth century but they also did not hesitate to establish fortifications and send Russian troops to the region to man the fortresses and for more efficient Iasak collection. When the government felt itself weak, for the sake of preserving peace with the natives it attempted to restrict migration to the Bashkir frontier. Under Peter the Great, however, the Russian state experienced a structural and ideological transformation. To meet Russia's growing needs for material and revenues, both Peter and his successors encouraged state-sponsored colonization of Bashkir lands because by this time thanks to the complex fortification system which suppressed and prevented nomadic disturbances.

Bashkirs resisted the colonization of their lands fiercely but once they realized further resistance futile, they successfully adapted themselves to the settled life which ensured their survival as a national group. This was a long and very difficult process for the nomadic Bashkirs. There were psychological and social hindrances that prevented many from settling until the moment they were left no other choice. First, those Bashkirs who sedentarized had to deal with the hardships of a new culture to which they were alien. Then they had to find a place for themselves among the already sedentary communities as inexperienced farmers. On the other hand as Anatoly Khazanov argues the sedentarization of an individual family would tear the 
nomad of the already existing social ties and lines of defense provided by fellow nomads. ${ }^{90}$ It was not an easy choice for most of the Bashkirs to sedentarize. Upon settling they had to carve out formerly nomadic pasturelands for fields. Their nomadic fellows would turn their aggression against them, probably considering them renegades and depriving them of pasturelands. As noted earlier, in the traditional Bashkir society, land was communally owned and it was open to all nomadic Bashkirs of the same clan. So the decision of some Bashkirs to settle down would seriously weaken the nomadic economy.

Though they had lost most of their lands to the colonizers, Bashkirs were not completely deprived of their lands. The remaining lands were large enough for an agricultural economy and the only choice under the circumstances for the Bashkirs was to sedentarize and to adopt an agricultural economy.

\footnotetext{
${ }^{90}$ Anatoly M. Khazanov, Nomads and the Outside World, (London \& New York: Cambridge University Press, 1984), 199
} 


\section{Chapter 6 \\ The Islamization of Bashkirs}

Islam is an urban religion. It originated in Mecca, the greatest urban center in the early 600s in the Arabian Peninsula and then moved to another city, Yathrib, later called Medina, literally "the city." The first message was Iqra! (recite!), a genuine urban message. For the most part of the history of Islamic civilization this religion flourished in the prominent urban centers of Middle East like Kufa, Baghdad, Basra, Mecca, Medina and Damascus. ${ }^{1}$ Accordingly for most of the Islamic Golden age from roughly 700 to the 1200 s the great Sunni jurists produced fatwas (opinion) specifically for the urban or sedentary societies. The focus of the great Sunni faqihs (Canonists) of Islam² had always been urban or sedentary communities.

So the impracticality of leading an Islamic life for nomadic peoples caused a certain degree of consternation among the Muslim scholars. This obstacle relating to conversion to Islam could only be overcome with the emergence of a new type of Islam, quite distinct from mainstream orthodox Islamic understanding. Sufism, a more lenient and more compromising form of Islamic understanding, freed itself from the formal ways of leading an Islamic life, such as praying five times daily, seclusion of women, fasting, or ritual ablution which are very difficult to observe in nomadic societies. Turkic groups of Central Asia were mostly nomadic peoples and their conversion to Islam by means of wandering Sufi dervishes was a great transformation for these peoples in the long run. Yet the effects of Islam were not felt immediately.

\footnotetext{
${ }^{1}$ Jere L. Bacharach, ed., Medieval Islamic Civilization 2 volumes: An Encyclopedia, (New York: Routledge, 2006), 702.

${ }^{2}$ These great Sunni faqihs whose teachings gained wide popularity and nearly universal acceptance among Sunni Muslim population are Imam Ahmad bin Hanbal, Imam Malik, Imam Shafii and Imami Azam (Great Imam) Abu Khanifa.
} 
The most widespread and most urban oriented Sunni school is Hanafiyya, which emerged in the major urban centers of Iraq, Kufa and Baghdad and spread mainly in a northern direction towards Central Asia. So when Turkic peoples of Central Asia converted to Islam they predominantly chose Hanafi madhab (School of Jurisprudence). The Turks' choice of Hanafiyya type of Islam indicates that their conversion to Islam did not take place as a result of comprehensive thought. Largely the Turkish leaders preferred this school for political motives since at the time most of their Muslim neighbors were Hanafi Muslims. As Ramila Thapar argues, their decision to convert to Islam and their dedication to create powerful states coincided and Islam provided them a powerful and legitimate tool in western Asia where the majority of the population was Muslim. ${ }^{3}$ So, it seems that this radical decision was not the result of a spiritual enlightenment. However during the second or subsequent generations, it generally became obvious that from among these new converts powerful religious figures appeared and they determined the future Islamic course of their peoples. ${ }^{4}$

\section{Bashkirs' Conversion to Islam, 900s to 1300s}

The conversion of Turkic peoples to this new religion started in earnest around the beginning of the tenth century. Their conversion took place en masse when the tribal leaders chose to convert to Islam. One factor for embracing Islamic faith might have been the rise of intercultural, economic relations between Central Asians and the Muslims of Iran. ${ }^{5}$ Islam among Bashkirs, a stateless Turkic group, developed in a more natural way thanks to the peaceful preaching of the Muslim Turkic missionaries from the already Islamized Central Asia who were

\footnotetext{
${ }^{3}$ Romila Thapar, Early India: From the Origins to AD 1300, (Berkeley, Calif.: University of California Press, 2002), 425.

${ }^{4}$ The most famous of these Turkish Muslim activists was Ahmad Yasawi (d. 1066).

${ }^{5}$ Among Turks, many of the Islamic terms relating to daily life are of Persian language. Vodoo (Ritual Ablution) is Abdest; Salat (Daily Prayer) is Namaz; Sawm (Fasting) is Oruch.
} 
mostly Sufi mystics. ${ }^{6}$ Allen J. Frank argues, based on Bashkir legends that Bashkirs' conversion to Islam took place largely thanks to the wandering dervishes (Sufi mystics) who came from Central Asia, Baghdad and Anatolia. ${ }^{7}$ Bashkirs were well aware of the writings of these Sufis and used their verses in composing their national folk music. They widely relied in this context on the poetry of Makhmud Gali al-Bulghari $\left(13^{\text {th }}-14^{\text {th }}\right.$ centuries), Mukhamediar Makhmud (d. 1552), and Mukhamet Chelebi (d. 1451) ${ }^{8}$

The Bashkirs' conversion to Islam also took place from another direction. The Golden Horde ruler, Uzbek Khan, upon converting to Islam in 1323, very vigorously embarked upon the conversion of the shamanist peoples of his empire and in this effort he employed the already Muslim Bashkirs. He sent them to the river valleys of Menzele, Ik, Zai, Belaia, Ufa, Dema, Chermasan, Ai and Ashkadar. Sometimes Bashkir Murzas like Baitura Khan led these conversion efforts. ${ }^{9}$ These efforts were either peaceful or forceful but were largely successful to ensure at least nominal conversion of Bashkirs. Evidence from their funerals in the late 1300s indicated that they still had preserved some of their shamanistic ways and they still insisted to use Shaman Turkic Sky God "Tengri” in place of its Arabic "Allah."10

\footnotetext{
${ }^{6}$ Ravil' Bukharaev, Islam in Russia: The Four Seasons (New York, St. Martin's Press, 2000), 154.

${ }^{7}$ Allen J. Frank, Islamic Historiography and Bulghar Identity Among the Tatars and Bashkirs of Russia (Leiden: Brill, 1998), 92; Frank must have been talking about a much later period, like the 1400s because Islamization and Turkification of Anatolia took place around the later 1200s. Even then there was a significant Paganistic Muslim Turkish population who were still arriving to Anatolia. Ethel Sara Wolper, Cities and Saints: Sufism and the Transformation of Urban Space in Medieval Anatolia (University Park: The Pennsylvania State University Press, 2003), 102.

${ }^{8}$ I. G. Akmanov and Aznagul Uruskulov, ed, Bashkirskaia Entsiklopediia, v. 4, (Ufa: Nauchnoe Izdatel'stvo, 2005), 140 and 311; G. B. Faizov, Gosudarstvenno-Islamskie Otnosheniia v Povolzhe i Priurale, (Ufa: 1995), 37 ; N. A. Mazhitov and A. N. Sultanova, Istoriia Bashkortostana s Drevneishikh Vremen do 16 Veka (Ufa: Kitap, 1994), 352; The authors argue that the folkloric features and literature of Bashkirs were closely tied to those of Middle Volga, Kazakhstan and Central Asia.

${ }^{9}$ V. V. Veliaminov-Zernov, "Pamiatnik s Arabsko-Tatarskoi Nadpis'iu v Bashkirii” Trudy Vostochnogo Arkheologicheskogo Obshchestva, Part 4, (1859), 267-273; N. V. Ustiugov, et.al., Ocherki Po Istorii Bashkirskoi ASSR, v. 1, part 1, (Ufa: Bashkirskoe Knizhnoe Izdatel'stvo, 1956), 69.

${ }^{10}$ G. N. Garustovich, "Rasprostranenie Islama v Iuzhno-Ural'skom Regione” in Problemy Dukhovnoi Kul'tury Tiurskikh Narodov SSSR, (Ufa: 1991), 26-27
} 
So it is misleading to assume that Bashkirs' conversion to Islam was the Islamization of the community and embracing an orthodox form of Islam. ${ }^{11}$ Yet despite the superficiality of their conversion, there was a rising invasion of Arabic vocabulary in the works of the folk poets and some existing Bashkir written documents. In Kuzeev's "Bashkir Genealogy” (Bashkirskie Shezhere) one can come up with many Arabic words like Kismet (the things that will happen to you in your life), Muqatele (mutual killing), Salahiat (warrant) or more Islamic words in Arabic like Haq (one of the names of God, the Truth), Ulu (Divine). ${ }^{12}$

Despite all these hints of an infiltration of Islam at least in verbal ways, it is still too early to talk about a real adoption of basic Islamic tenets, for example, relating to cleanliness or Halal food. Ibn Fadlan reported in the 920s that Bashkirs, after he had seen many other Turkic groups on his way to the Bulghar state, were the most wicked of all Turks, the dirtiest of them, and the most audacious in the commission of murder. He considered them still pagan. He mentions that his guide was a Muslim Bashkir with slightly pagan ways. At the time, his conversion to Islam had not made him abandon his pagan past's noisome manners like crushing lice and licking it. ${ }^{13}$ As Ernest Gellner puts correctly "In principle, the Muslim, if endowed with pious learning, is self-sufficient or at any rate not dependent on other men, or consecrated specialists. (If not learned, he is in a loose way dependent on those who are, which is very important.) Thus

\footnotetext{
${ }^{11}$ I take Islamization as undergoing a radical change in lifestyles and culture from manners to the simplest details like embracing Arabic names. In the earlier stages of the conversion of Turks into Islam around the eleventh century Turkish names like Alpaslan, Tughrul(Dumrul), Chagri were considerable among the Central Asian ruling elite. A century later Arabic names like Alaaddin, Izzeddin or Giyaseddin and to a degree Persian names like Keykavus, Keyhusrev replaced them.

${ }^{12}$ R. G. Kuzeev, Bashkirskie Shezhere (Ufa: Bashkirskoe Knizhnoe Izdatel'stvo, 1960), 77 and 81.

${ }^{13}$ Richard Nelson Frye, Ibn Fadlan's Journey to Russia: a Tenth-Century Traveler from Baghdad to the Volga River, (Princeton: Markus Wiener Publishers, 2005), 43.
} 
officially Islam has no clergy and no church organization, though it needs scholars, and church and community are co-extensive" ${ }^{, 14}$

In light of the above statement it becomes clear that Islamization requires a certain degree of learning, which is possible only with the foundation of educational institutions. It must, however, be underlined that these institutions are not supposed to be highly complex well established and deeply sophisticated foundations. One simple room, in times of extreme urgency even that room could be dispensable, and one elementary level mullah are good enough to introduce the basics of Islam to the shakirds (students). This simplicity of the instruments of Islam was a basic reason for the resilience of Islam and its successful survival during Imperial Russian and Soviet regimes over the centuries despite sporadic persecutions. In the face of state repression, an ordinary Muslim could easily hide his real identity through taqiyya, a method of self-defense by hiding real thoughts and beliefs against an insurmountable enemy. This method, condemned by Sunni schools, is in fact used by the Shia School.

More than a century after Ibn Fadlan, another Arab traveler and geographer Yakut alHamavi (1179-1229) reports that he met a number of Bashkir madrasa students in Aleppo, a prominent city in northern Syria, and interviewed them. These students came to Arab lands to study Islam, specifically Hanafi School. They further related to al-Hamavi that their conversion to Islam was accelerated by the missionaries from the Bulghar state and they wanted to learn this new religion and spread it to the rest of the Bashkirs and occupy high positions in their own society. ${ }^{15}$ Relying on this account it can be stated that Bashkirs at a quite early stage of their history as Muslims started to create their own Muslim scholarly class. This evidences the

\footnotetext{
${ }^{14}$ Ernest Gellner, Muslim Society, (Cambridge: Cambridge University Press, 1981), 1.

${ }^{15}$ Sehabeddin Mercani, Mustefadu'l-Ahbar fi Ahval'i Kazan ve Bulgar, (Ankara: Ankara Kultur Merkezi Yayini, 2008), 72-73.
} 
development of an institutional Islam which would take its final form with the foundation of the Orenburg Muslim Spiritual Assembly under Russian tutelage.

The Bashkirs' conversion to Islam gained momentum with the official acceptance of Islam by the Golden Horde sultan Uzbek Khan in 1323. Surrounded by a mighty Muslim kingdom to their north and Muslim Central Asians to the south, the Bashkirs' massive conversion to Islam during this period is not surprising. ${ }^{16}$ Still this intrusion of Islamic faith into the Bashkir lands remained superficial. Beneath the Islamic make-up shamanistic ways were mostly preserved because of the fact that their nomadic life style did not allow them to develop a distinctive Bashkir Islam culture until long after the arrival of the Russians.

Despite all the superficiality of their conversion to Islam, they were quiet eager to preserve such Muslim identity as they had already embraced. By insisting on the Russian Tsar's toleration of their religious freedom and the right to keep themselves away from the Russian missionaries, they were in fact defending their nomadism. Concessions to their religious beliefs could require concessions in other fields of their lives especially in their economy and life styles. So Islam became one of the main means of expression of the Bashkir autonomy. Otherwise they were not so much willing to lead a purely Islamic life. However this unwillingness to lead an Islamic life was not due to their aversion to religion but rather due to their nomadism.

Muslim scholars, the founders of madhabs, great jurists of the first 250 years of Islamic history, all responded to the needs of sedentary societies and found solutions to their problems pertaining to leading an Islamic life. Take daily prayer. It is interpreted from the sources of Islam (Hadith and Quran) that any person who is not a traveler has to pray on a regular basis, considering the time of the day and cleanliness of the place and clothes of the believer. When

\footnotetext{
${ }^{16}$ Ravil Bukharaev, Islam in Russia: The Four Seasons (New York, St. Martin's Press, 2000), 154.
} 
matters come to a traveler it is determined that such a person is authorized to combine two prayers to ease the journey. ${ }^{17}$ So he can pray three times a day instead of usual five times. However when the matters came to a constant wanderer who is essentially a nomad, no Islamic jurist gave any opinion. It is almost impossible for a nomad to lead a thoroughly Islamic life. So the Islamization of Bashkirs required their sedentarization. ${ }^{18}$

\section{Bashkirs' Embrace of Islam and Russia's Muslim Question}

The superficial face of Islam in Bashkir society gradually disappeared over the course of more than hundred and fifty years from 1552 through the seventeenth century. The greatest role in this transition to a more institutionalized form of Islam took place under the impact of the more Islamized Volga Tatars. As discussed above, they had to abandon their homes in middle Volga region in the wake of the fall of Kazan and subsequent Russian excesses against the local population upon the orders of the Russian Tsar Ivan IV. By more Islamized I mean an already developed sedentary culture among the Tatars of Kazan and accordingly a more formal and a more institutional form of Islam in which mosques and madrasas occupied a central place.

Generally speaking these were missing among the semi-nomadic and nomadic Bashkirs. among These institutions could be seen the Bashkirs of western Bashkiria where a sedentary culture had already developed and the Tatar impact was the greatest. ${ }^{19}$

\footnotetext{
${ }^{17}$ Shafii School is more explicit about the issue of combining prayers than the Hanafi School, the most urban interpreter of Islam, which rarely thought that a person in a Muslims urban center where mosques are many could miss prayers.

${ }^{18}$ This sedentarization took place over the course of sixteenth to nineteenth centuries.

${ }^{19}$ There are stereotypes about the ethnic background of these Bashkirs among the Tatar-Bashkir population of the autonomous republic of Bashkortostan which are shared by the officials of the republic. This stereotype, Koltso reports, asserts that Bashkirs of western Bashkiria are not genuine Bashkirs but a mixture of Tatars and Bashkirs. Pal Kolsto, Nation-Building and Common Values in Russia, (Lanham: Rowman \& Littlefield Publishers, 2004), 90: However this stereotype is far from being groundless as chapter four discussed to a degree: See also I. M.

Gabdrafikov, "Etnokulturnye Rezultaty Migratsionnykh Protsessov v Severo-Zapadnoi Bashkirii (Konets 16Nachalo 20 v.)" in Etnologicheskie Issledovaniia v Bashkortostana, ed., I. M. Gabdrafikov, (Ufa: 1994), $22-28$. 
Since the frontiers were the areas of liberties where the state authority was lax, an Islamic preacher could wander in the Bashkir lands without any state supervision or regulation. They were not subject to any centralized hierarchical control and they freely preached their own version of Islam whose authenticity could be quite questionable. ${ }^{20}$ The distinguished Tatar Muslim scholar Rizaeddin Fakhreddin relates the story of a Tatar mullah, Mansur bin Abdrakhman, from a village along the Zei river who traveled widely. He went to pilgrimage to Mecca and studied Islamic sciences in the madrasas of Bukhara. After graduation (receiving Ijazat) he finally returned back to his native Volga-Ural region and began to educate the Muslim youth in the region. He made his distinction in many Islamic fields and widely revered by the Muslim peoples of the region until he died in $1720 .^{21}$ Mansur's story was by no means exceptional. There were many other shakirds, and mudarrises who widely and internationally traveled and received Islamic education from the madrasas beyond the lands of Russia and they were able to disseminate their own version of Islam in the Volga Ural region and among Bashkir peoples.

The conquest of Kazan and Astrakhan respectively in 1552 and 1556 made Muscovite Russia a multi-confessional state. In the wake of the conquest of Kazan, the initial attitude of the Russian tsar and his officials was quite cumbersome and devastating for the Muslims of the Middle Volga region. Partly this was due to the nature of the Russian expedition against Kazan

\footnotetext{
${ }^{20}$ As late as the $1850 \mathrm{~s}$, Agnes Kefeli argues, popular Islam, a form of Islam spread by self-taught and self-made Muslim missionaries, was full of un-Islamic elements based on the oral traditions, unauthentic saintly miracles etc. Agnes Kefeli-Clay, "Krashen Apostasy: Popular Religion, Education and the Contest over Tatar Identity, 18561917" (PhD diss., Arizona State University, 2001)

${ }^{21}$ Danielle M. Ross, "In Dialogue with the Shadow of God: Imperial Mobilization, Islamic Revival and the Evolution of an Administrative System for the Tartars, Bashkirs and Mishars of 18th-century Russia," (M.A. Thesis, University of Madison Wisconsin, 2007), 24; Shihabuddin Marjani also talks about the same person in a different context arguing that this Mansur mullah was also the father of the first mufti (a Muslim scholar- official who is entitled to give fatwas; A mufti is also the official head of the Orenburg Spiritual Assembly) of the Orenburg Muslim Spiritual Assembly, Muhammadjan Husseinov. But It is known that Muhammadjan Huseionov was born in 1758, nearly 40 years after Mansur mullah died.
} 
which took the form of a crusade and taking vengeance against the centuries-long Mongol then Tatar yoke. ${ }^{22}$ Accordingly the male population of Kazan was slaughtered, women and children were enslaved and mosques were destroyed upon the personal orders of Ivan IV. ${ }^{23}$ Even though this violent policy was reversed shortly after the conquest of Kazan in 1555 and the use of force to convert Muslims to Christianity was discouraged, the harm had been done and Russia's Muslim question seriously started.

Relations between Russian governments and Muslim peoples of Russia evolved through several stages from 1552 to the fall of the Russian empire in 1917. These stages mark radical fluctuations in the Russian state's attitude towards the Muslim subjects and were efforts by the government to respond. So the Muscovite and Imperial Russian political attitude towards Islam and Muslims, despite being eternally suspicious, was an extension of Russian pragmatism rather than dogmatic religious fanaticism. While the first three Romanov Tsars' attitudes toward Muslims were relatively liberal ${ }^{24}$, Peter the Great and his immediate successors applied considerable repression, as discussed in previous chapters. ${ }^{25}$ This radical change was most possibly because of the state's insistence on integrating non-Russians into the Russian system. It must be noted that the first three Romanov tsars' reigns were one of the periods of recuperation from the wounds of the Time of Troubles and the central government was still relatively weak.

The Russian government was often suspicious of the Muslim population because Russia had by far the largest Muslim population of any European state and that population often

\footnotetext{
${ }^{22}$ Andreas Kappeler, The Russian Empire: A Multiethnic History (Harlow: Longman, 2001), 27

${ }^{23}$ Sergei M. Soloviev, History of Russia, vol. 10: The Reign of Ivan the Terrible; Kazan, Astrakhan, Livonia, the Oprichnina and Polotsk Campaign, (Gulf Breeze, Fl.: Acad. Internat. Press, 1995), 24: Soloviev portrays Kazan campaign as a "sacred undertaking, a campaign to defend Christianity from Islam" ibid , 29.

${ }^{24}$ This term cannot conceal the fact that Russian government under Tsar Alexei issued a harsh law which aimed at forcing Tatars financially to accept Greek Orthodox faith. PSZ, v. 9. no. 867

${ }^{25}$ Alexandre A. Bennigsen, \& C. Lemercier-Quelquejay, Islam in the Soviet Union, (New York, Praeger, 1967), 12; Robert D. Crews, For Prophet and Tsar; Islam and Empire in Russia and Central Asia, (Cambridge, Mass.; London: Harvard University Press, 2006), 16.
} 
challenged Moscow's authority. ${ }^{26}$ The government at times followed a conversion policy, and the Muslims in response developed new ways to preserve their religious identity through various means. Mass migration to other parts of the empire was one such method. ${ }^{27}$ While the state's use of force to convert Muslims was more common in areas where the state's authority was stronger, the frontier regions were islands of religious freedom despite sporadic and ambiguous state attempts to proselytize the peoples of Bashkir frontier. ${ }^{28}$ As noted previously, the Muslim Tatars of the Middle Volga faced state-sponsored, church-led violence in the 1740s and 1750s but those Muslims who lived on the right side of the Volga lived relatively freely. However this ambiguity led the Russian authorities to consider their chances to convert Bashkirs and the foundation of an episcopate (Eparkhiia) in Ufa was proposed but this idea was quickly abandoned as impractical. ${ }^{29}$

\section{Bashkir Rebellions in Defense of Islam}

Russian policies toward Islam and Muslims varied from time to time and lacked a fixed, clear-cut, well-determined political program. In fact Muslims of the Middle Volga especially sensed the arbitrariness of the Russian monarchs and their agents in the provinces. While one

\footnotetext{
${ }^{26}$ Shoshana Keller, To Moscow, not Mecca: The Soviet Campaign against Islam in Central Asia, 1917-1941, (Westport, Conn.: Praeger, 2001), 1.

${ }^{27}$ Tatars definitely were not alone in seeking religious freedom in the frontier areas. American frontier studies have a number of books which briefly mention this issue. See R. Douglas Hurt, The Ohio Frontier: Crucible of the Old Northwest, 1720-1830, (Bloomington: Indiana University Press, 1996); John Solomon Otto, The Southern Frontiers, 1607-1860: The Agricultural Evolution of the Colonial and Antebellum South, (New York: Greenwood Press, 1989) If the issue is to populate the frontiers and make it an integral part of the empire the religious differences matter much less. The governments even abandon their religious obsessions and encourage settlers from different confessional groups to populate the frontier; Marianne Schmink and Charles H Wood, Frontier expansion in Amazonia, (Gainesville: University of Florida Press, 1984), 235.

${ }^{28}$ Russian government's proselytizing efforts towards the Bashkirs was the least successful. The number of Bashkirs who had been sold into slavery in due course of the Bashkir rebellions was huge but the actual Bashkir converts remained minimal by the end of the eighteenth century.

${ }^{29}$ Nikolai Chernavskii, “Orenburgskaia Eparkhiia v Proshlom i Nastoiashchem” Trudy Orenburgskoi Uchenoi Arkhivnoi Kommissii Vypusk 1 (1900), 101.
} 
official remained indifferent to Muslims another could embrace a quite antagonistic attitude towards them. As a result the period from 1552 to the foundation of Orenburg Muslims Spiritual Assembly in 1788 was a period of irregular and unpredictable persecution.

Coincidentally, the greatest Bashkir revolts took place during this period. Even though Bashkirs thanks to their frontier location were not the main targets of the Russian state's religious persecution they nevertheless twice rebelled in 1681-1683 and 1755-1756 partly because of the ambiguity of the Russian state's posture to their religious sensitivities. The Russian government attempted to impose Russian culture and Christianity among peoples of Middle Volga in 1676, provoking a rebellion that spread to western parts of Bashkiria. The rebellion started in earnest in 1681 upon the decree by the authorities which ordered the conversion of Tatar Murzas (Nobles) and common Tatars into Christianity. Animistic Bobyls appealed to the authorities about the excessive financial demands by the Tatars landowners and Tatars' insistence on Bobyls' conversion to Islam. "Apparently Murzas and Tatars in their pomesties (a type of land not inheritable but given in return for service) and votchinas are imposing heavy taxes on the peasants, causing resentment and forcing the peasants to adopt Muslim faith." ${ }^{30}$

So the war of religions in fact was working in two different directions. Tatar Muslims of Middle Volga region apparently were not idly waiting for their ultimate forceful conversion to Christianity. They had their own means of struggle against Russian authority. These Muslims communities in the Tatar lands just 200 miles from Moscow were intolerable for the Russians and they moved vigorously against Volga Tatars to convert them, a policy which reached its

\footnotetext{
${ }^{30}$ PSZ, v. 2, no: 867
} 
peak in the mid-1740s. ${ }^{31}$ The Tatar communities' defiance against the proselytizing policy of the Russian state and their active missionary activities among the pagan peoples of the Middle Volga region probably infuriated the Russian authorities. As a response to Tatar resistance, they increased their pressure on Volga Tatars which led to their flight into Bashkir lands.

Tatar immigration and expansion of Russian efforts to convert Bashkirs provoked Bashkirs to rebellion in the early $1680 \mathrm{~s}$. A key cause of the outbreak seems to have been the rumor about the Bashkirs' forceful conversion to Christianity. ${ }^{32}$ But there was palpable evidence which added credibility to this rumor, because an Orthodox bishop was appointed to Ufa. The idea of establishing an office of episcopate was based on the Russian wish to bring the Christian message to the "savages" of Siberia. ${ }^{33}$

As was discussed in chapter 2, this led to the outbreak of the first religious rebellion of Bashkirs. The religious nature of the rebellion was boosted by a rebel leader, a man called Seit, who had a religious background. A primary text used by famous Russian Tatar orientalist Katanov states that Seit was a Sufi saint who emerged among the Bashkir khans, and whose full name was Seiid Dzha'far. He was alleged to be a miracle worker and he invited people to join the Islamic faith. Yet the Bashkir peoples did not recognize him as a khan, refused to obey his orders (perestali zhit' po ego prikazanie). ${ }^{34}$ So there was a limit of the influence of the religion

\footnotetext{
${ }^{31}$ Alexandre Bennigsen and Marie Broxup, The Islamic Threat to the Soviet State (New York: St. Martin's Press, 1983), 16.

${ }^{32}$ V. V. Boguslavskii, Slavianskaia Entsiklopediia, v.1,(Moskva: Olma-Press, 2004), 100.

${ }^{33}$ Akty Istoricheskie,1676-1700, 5 (1842), 109; Danil D. Azamatov, "Russian Administration and Islam in Bashkiria $\left(18^{\text {th }}-19^{\text {th }}\right.$ Centuries)" in Muslim Culture in Russia and Central Asia from the 18th to the Early 20th Centuries vol. 1, ed., Michael Kemper, Anke von Kugelgen and Dmitriy Yermakov, (Berlin: Klaus Schwarz Verlag, 1998), 93; I. G. Akmanov, Bashkirskoe Vosstanie 1735-1736 gg. (Ufa: Bashkirskoi Gosuniversitet, 1977), 15.

${ }^{34}$ N. M. Katanov and I. M. Pokrovskii, "Otryvok iz Odnoi Tatarskoi Letopisi o Kazani i Kazanskom Khanstve" Izvestiia Obshchestva Arkheologii, Istorii, i Etnografii pri Imperatorkom Kazanskom Universitete, 21 (Kazan 1905), 319. See also I. G. Akmanov, Bashkirskie Vosstaniia 17-Pervoi Treti 18 v. (Ufa: Bashkirskie Gosuniversitet, 1978), 46
} 
among Bashkirs. Their refusal to recognize him as the ultimate leader of Bashkirs is evidence that Islam was still not a fundamental part of the Bashkir communal life.

Still, Seit's Islamic background did not represent a major breach in the already existing nomadic culture of the Bashkirs in the seventeenth century. From the available archival data, it is difficult to determine the influence of Islam within the Bashkir communities. Neither Imperial Russian nor Soviet and Post-Soviet scholars tend to study the place of Islam in the nomadic life. What we know for sure from this period about the Bashkir society is that the Bashkir people were only nominally Muslim and there are not available data if they had their own Islamic institutions like madrasas and mosques. Despite these institutional shortcomings they nevertheless embraced Islam by the 1680s and considered it as an inseparable part of Bashkir culture and were ready to defend it.

As a result, the Russian government had to ensure that it had no proselytizing policy towards Bashkirs after the 1681-1684 rebellion. ${ }^{35}$ This was the real success of the Bashkirs because the Tsar considered them not as rebels but as wronged subjects with whom the government had to negotiate. The long-term results of this rebellion and the eventual concessions by the tsar were that there would be no more serious consideration, with the exception of an ambiguous attempt in the first decade of the eighteenth century, by the authorities to force Bashkirs to convert to Christianity. ${ }^{36}$

The ulama of the Volga-Ural region until Batyrsha did not form an alternative leadership to the traditional Bashkir nomadic structure but it was clear that they had managed to attach themselves to the existing leadership structure as secondary partners. From the 1660 s on for the

\footnotetext{
${ }^{35}$ Iu, N. Sergeev, Pravoslavnaia Tserkov v Bashkortostane Vtoraia Polovina 16-Seredine 19 Veka, (Ufa: Bashkirskii Universitet, 1996), 29; N. V. Ustiugov, et.al., Ocherki Po Istorii Bashkirskoi ASSR, v. 1, part 1, (Ufa: Bashkirskoe Knizhnoe Izdatel'stvo, 1956), 122-123.

${ }^{36}$ Z. I. Siraev, "O Kharaktere Bashkirskikh Vostanii 17-Pervoi Poloviny 18 vv. (1662-1664 gg.; 1681-1683 gg.; 1704-1711 gg.; 1735-1740 gg.)” in Iz Istorii Bashkirii Part 2, ed., R. G. Kuzeev, (Ufa:1963), 21.
} 
rest of the history of the Bashkir rebellions against the Russian state they always played an active role in mobilizing people against the state or as intermediaries to conduct relations between local people and the state. They attempted to create conditions for negotiable peace and they were sent by the Russian state to the insurgents to abandon fighting. They emerged as a social group with leadership potential even though they in principle did not have to have noble blood. So any person from a modest background with adequate religious training and popularity could emerge as a leader of their community. ${ }^{37}$

The classical madrasa system in Central Asia where many Bashkirs and Tatars studied and accordingly brought the same system back to their native Volga-Ural region was "based on one's educational background, specifically the acquisition of knowledge through a maktab (Islamic high school) then a madrasa education.... Moral character, knowledge of authoritative texts, ethical norms, personal development, and spiritual cultivation (all aspects of the Islamic ideal of $a d a b$ ) were acquired by individuals through the shared experience of traditional Islamic education." ${ }^{38}$ Any scholar in Bashkiria who received a similar religious education could easily bring the congregation under his spell. Also during this period a mullah was not only a religious

\footnotetext{
${ }^{37}$ Materialy po Istorii Bashkirskoi Istorii, part 1, Bashkirskie Vosstaniia v 17 i Pervoi Polovine $18 v v$. (Moskva\&Leningrad: Izdatel'stvo Akademii Nauk SSSR, 1936), 226-227;Two Bashkir mullahs Mriak Mulla and Opach' Mulla together with two other Bashkir tarkhans were sent to insurgents by the authorities in 1709 to persuade them to submit to the Russian state see, Materialy po Istorii Bashkirskoi Istorii, part 1, Bashkirskie Vosstaniia v 17 i Pervoi Polovine 18 vv. (Moskva\&Leningrad: Izdatel'stvo Akademii Nauk SSSR, 1936), 266; They were at times used as envoys to the other Turkic Muslim peoples as Alikei mulla was sent to Kazakh khan in 1737 Materialy po Istorii Bashkirskoi Istorii, part 1, Bashkirskie Vosstaniia v 17 i Pervoi Polovine $18 v v$. (Moskva\&Leningrad: Izdatel'stvo Akademii Nauk SSSR, 1936), 346; the two most prominent leaders of the 17351740 rebellion were Mulla Eldash Siuarymbetov and Abyz Bepen Toropberdin. Eldash Mulla was also the ideologue of the rebellion. See; N. F. Demidova, "Bashkirskaia Vosstaniia 30-kh Godov 18 v." in Materialy po Istorii Bashkirskoi ASSR: Orenburgskaia Ekspeditsiia i Bashkirskie Vosstaniia 30-kh Godov XVIII v. vol. 6, compiled by N. F. Demidova (Ufa: Kitap, 2002), 7.

${ }^{38}$ Jo-Ann Gross, "Historical Memory, Cultural Identity and Change: Mirza Abd al-aziz Sami's Representation of the Russian Conquest of Bukhara" in Russia's Orient: Imperial Borderlands and Peoples, 1700-1917, ed., Daniel R. Brower, Edward J. Lazzerini (Bloomington: Indiana University Press, 1997), 204.
} 
servitor and opinion leader but also a physician. As a result they could perform many different and vital tasks in the community.

Peter the Great made Orthodox Church subject to his will and authority and he strongly differed from his predecessors in his policy towards the Muslims of the empire. He had radical plans to make Russia modern and more European which included changes in the status of the Muslim subjects. ${ }^{39}$ For example Christianity was now the precondition for joining the landowning service elite. Those who refused to convert were reduced to the status of peasants and lost their lands. ${ }^{40}$ Accordingly the main cause of the Tatar exodus to Bashkir lands was the state's relentless attacks on Muslims in Kazan Gubernia who lived not far away from Moscow. The government's efforts to persuade them to return failed as the Tatars and Mishars of Bashkiria and Bashkirs themselves refused to obey the order of the state. "Many inovertsy have escaped from the towns of the Kazan Gubernia and they continue to escape to Ufa uezd and Bashkirs of Ufa and Mishars and Tatars refuse to return those fugitives." ${ }^{41}$ These people who escaped from Christianization to the safety of Bashkiria in the early 1700s were the most devout ones religiously and at the first opportunity they introduced their Islam to Bashkirs.

The Russian government's attitude in Bashkiria in matters relating to Islam was quite timid, due to the weakness of the tsarist authorities in the region. The rebellion in the 1680 s was a good indicator that Bashkirs were quite intolerant of violation of their religious convictions

\footnotetext{
${ }^{39}$ Peter the Great unlike earlier Russian tsars was eager to learn the basic tenets of Islam and shape his future policy about the Muslims of the empire. For this reason he had Quran translated into Russian and read it. On the other hand he intervened to allow the publication of Dimitry Kantemir's book, The System of the Religion and Conditions of the Turkish Empire, which was censored by the Orthodox Church for its quite liberal language about Islam. See, David S. Van Der Oye, Russian Orientalism: Asia in the Russian Mind from Peter the Great to the Emigration, (New Haven \& London: Yale University Press, 2010), 40-41.

${ }^{40}$ Robert D. Crews, For Prophet and Tsar: Islam and Empire in Russia and Central Asia, (London: Harvard University Press, 2006), 37-38

${ }^{41}$ Faizulkhak Islaev, Vosstanie Batyrshi god 1755, (Kazan: Fen, 2004), 28: Islaev did not mention the source of this archival document.
} 
which they saw as part of their Votchina rights. On the other hand the Russian government mistrusted Islamic elements within empire's frontiers, saw them as potentially prone to create disturbances, and the authorities attempted to have, even if minimal, gains against Islam in the regions where Muslims are majority as the imperial decree of 1704 exemplified. The governmental decree of 1704 is a good example of how Russians were keen on getting the minutest concessions from the Islamic community. They also avoided radical demands so as not to disturb already fragile balance between the state and the non-Orthodox confessional groups. The imperial authorities were not interested in destroying Islam but to make it a docile element within the empire. Peter the Great's discrimination of Muslims should have been considered as a state policy of making Christianity as the defining identity of the imperial administration, the Russian Orthodox church as a symbol of Russian statehood. ${ }^{42}$

As was already mentioned, the Bashkir rebellion of 1704-1711 was caused by the state's growing financial demands. These demands, however, also had religious components, On Peter the Great's insistence, including the conversion to Orthodoxy of believers from other faiths (inovertsy), ${ }^{43}$ the construction of mosques in the model of an Orthodox church, the requirement that marriages be held in the presence of an Orthodox bishop, and new taxes such as 5 rubles for each mosque and between 3 and 6 kopecks from each village imam and same amount of money from each mosque attendee. ${ }^{44}$ These were seemingly trivial details that proved to be important from the Russian point of view because of the fact that the state desired to achieve some sort of uniformity within the empire and control those elements that stood away from the center. The

\footnotetext{
${ }^{42}$ Galina M. Yemelianova, Russia and Islam: A Historical Survey, (New York: Palgrave, 2002), 42.

${ }^{43}$ For N. Firsov, Peter was deeply convinced that Russians had a historical Christian responsibility to Pagans and Muslims for their education (Vospitanie). N. Firsov, Inorodcheskoe Naselenie Prezhnego Kazanskogo Tsarstva $v$ Novoi Rossii do 1762 g. i Kolonizatsiia Zakamskikh Zemel' v Eto Vremia (Kazan; 1869), 131.

${ }^{44}$ A. Z. Asfandiiarov, "Religioznaia Politika Tsarizma v Bashkirii v Period Feodalizma" in Bashkirskii Krai, part 1, (Ufa, 1991), 4; Materialy po Istorii Bashkirskoi Istorii, part 1, Bashkirskie Vosstaniia v 17 i Pervoi Polovine $18 v v$. (Moskva\&Leningrad: Izdatel'stvo Akademii Nauk SSSR, 1936), 110 and 114-115
} 
bishop's presence as a servant of the government is a good indicator that the state attempted to monitor non-Orthodox elements more closely. The reaction was a direct attack against anything Christian which was seen as an expression of the state repression. In Kazan and Ufa uezds, rebellious Bashkirs burned down 75 churches in $1709 .{ }^{45}$

The Russian state attempted sporadically to improve the role of Orthodoxy in the public sphere, or at least to make it more visible to the Muslims. In this context the foundation of the Ufa episcopate in the heart of Bashkiria in 1681 can be counted. ${ }^{46}$ As the colonization of Bashkiria gained momentum and new town centers sprang up in the eighteenth century like Orsk, Troitsk or Orenburg, churches decorated each town center bringing the symbols of Orthodoxy just to the center of frontier life and an Islamic society. Tsars occasionally issued orders and decrees which forbade the forceful conversion of Muslims to Orthodoxy. These orders, however, did not prevent all proselytizing because they did not really provide a legal foundation for the recognition of the Muslim communities in the empire as a legal group. So the Tsar's protection of Muslim communities was highly inconsistent. The clearest expression of this inconsistency was that any Muslim who was found guilty of converting a Christian to Islam or reneging Orthodoxy could be burned at the stake. ${ }^{47}$ There were examples of such cases in Bashkiria. One of the most enlightened officials of the Imperial Russia, Tatishchev, applied this

\footnotetext{
${ }^{45}$ Materialy po Istorii Bashkirskoi Istorii, part 1, Bashkirskie Vosstaniia v 17 i Pervoi Polovine $18 v v$. (Moskva\&Leningrad: Izdatel'stvo Akademii Nauk SSSR, 1936), 252

${ }^{46}$ I. G. Akmanov, "Bashkirskie Vosstanie 1704-1711," in Sbornik Nauchnykh Rabot Aspirantov Istoricheskogo Fakul'teta MGU, (1963), 133

${ }^{47}$ Richard Hellie, trans., The Muscovite Law Code (Ulozhenie) of 1649 Part 1, (Irvine, California: Charles Schlacks JR., Publisher, 1988), 223.
} 
rule when a Christianized Bashkir, Toigyl'dy Zhuliakov, reverted back to his original Muslim faith in $1740 .^{48}$

\section{Bashkirs' Islamization and the Impact of Tatars}

Despite these inconsistencies, Bashkirs' embrace of Islam gradually increased. Islamic institutions slowly emerged within the Bashkir community. One of the main indicators of the Islamization of a community is the establishment of madrasas and their survival based on community support. In the classical Islamic educational system the shakirds (madrasa students) did not pay any fee but were supported by the community of the believers who generally founded charitable endowments (Waqfs) in support of these institutions and shakirds. The presence of madrasas and waqfs indicated sedentarization of that community because it showed that societal relations and efforts were united around a common goal. These institutions were run by Muslim scholars, initially without governmental control. Later on, realizing their potential of threat to the Russian state, the government started to take certain measures.

The Russian state first began to bring akhuns (highest religious authority in Bashkiria at district level) and mullahs under the supervision of the local administration in the $1730 \mathrm{~s} .{ }^{49}$ This coincided with the Orenburg expedition because one of the main concerns of the Russian authorities in Orenburg region was to minimize the influence of Tatars over Bashkirs. Ivan Kirilov complained about the influence of Tatars over the local population arguing that "In all those villages (between Volga and Ural mountains) the Tatars who moved from the Kazan

\footnotetext{
${ }^{48}$ N. M. Kulbakhtin, \& Iu. N. Sergeev, "Religioznaia Politika Tsarizma v Bashkirii" in Sotsialno-Ekonomicheskoe Razvitie i Klassovaia Borba na Iuzhnom Urale i v Srednem Povolzhe Dorevoliutsionnyi Period ed., I. G. Akmanov, (Ufa: Bashkirskii Universitet, 1988), 39.

${ }^{49}$ Allen J. Frank, Muslim Religious Institutions in Imperial Russia; The Islamic World of Novouzensk District and the Kazakh Iner Horde, 1780-1910, (Leiden, London, Koln: Leiden, 2001), 109; Franks maintains that akhuns significance declined by 1780s with the foundation of Muslim Spiritual Assembly.
} 
District live in the capacity of mullahs and abyzes (one who has memorized the entire Qur'an by heart). All of them are learned and intelligent men. Their word is received by the population as a word of a prophet. For that reason, Tatar mullahs and abyzes should be expelled from the Ufa district, and their madrasas should be closed, their students should be used as interpreters, etc.",50 He also pointed out a significant detail that all 10 akhuns $^{51}$ in Bashkiria were Tatars and requested a reorganization and closer governmental control over the services of akhuns. The law of 11 February 1736 ordered reduction of the Akhuns from 10 to 4, one for each Doroga in Bashkiria and specified that they be appointed by the state, a sign of the end of the free frontier world for religious activists. The same law also banned the construction of any mosque and school (Madrasa) without permission from the authorities. The Russian authorities in Orenburg considered this measure necessary due to the fact that religious ulama in the region took an active role in the rebellious movements and they even led a number of Bashkir raids directed against the Russian or "loyal" settlements. ${ }^{52}$

Yet despite the fears of Kirilov and other Russian officials about the threat from the Tatars, the Volga Tatar refugees had the greatest impact on the foundation and survival of these Islamic institutions and on the Bashkir society's Islamization. The first madrasas and maktabs in Bashkiria after its incorporation into the Russian empire in the mid-1550s appeared during the second half of the seventeenth century. These earlier madrasas were quite simple and had a basic curriculum i.e. reading the Quran and learning the basic rules of an Islamic life. ${ }^{53}$ One of the first and largest madrasas in Bashkiria was established in 1720 in Isterlibash, a Tatar

\footnotetext{
${ }^{50}$ Ravil' Bukharaev, The Model of Tatarstan: Under President Mintimer Shaimiev, (New York: St. Martin Press, 1999), 56-57.

${ }^{51}$ Akhun, a Persian word, is a term denoting a member of the Ulama.

${ }^{52}$ Faizulkhak Islaev, Vosstanie Batyrshi god 1755, (Kazan: Fen, 2004), 15.

${ }^{53}$ T. M. Aminov, M. G. Valeeva and Iu. N. Sergeev, "Dukhovnoe Obrazovanie" in Bashkirskaia Entsiklopediia, v.2, ed., I. G. Akmanov and Aznagul Uruskulov, (Ufa: Nauchnoe Izdatel'stvo, 2005), 530.
} 
settlement, founded between 1670 and $1680 .{ }^{54}$ Isterlibash made its fame as the Islamic education center of Bashkiria that attracted students from surrounding areas. ${ }^{55}$ At some point for several decades, there were as many as 150 Kazakh students attending madrasas in Isterlibash and spending at least ten years among their ethnic brethren and coreligionists. ${ }^{56}$ The brightest years of the madrasa were in the early 1800s under the mudarris (Professor at the Madrasa) Nigmatullah Tukaev and his sons Muhammad Kharis and Muhammad Kharras, both of whom graduated from the madrasas in Bukhara. In the early nineteenth century Isterlibash boasted nearly 25 madrasas with a total 200 shakirds. $^{57}$

The pattern that affected the functioning of a classical Volga Ural madrasa was determined by the factors that could be seen in other parts of the Muslim world as well. In the classical Islamic madrasa system the shakirds choose their professors rather than the madrasa itself. Since the Volga Ural madrasas mostly employed only one mudarris and these mudarrises specialized most of the time in only one Islamic field and mostly they owned one textbook, the shakirds would study with that mudarris for a certain time and after they got ijazat (literally permit; diploma) they would search for another mudarris to study another field of the Islamic sciences. In Islamic countries of the time state-sponsored madrasas, though few in numbers, could provide education in many fields. In Russia, on the other hand, the Muslim population

\footnotetext{
${ }^{54}$ S. M. Prozorov, ed., Islam na Territorii Byvshei Rossiiskoi Imperii, Entsiklopedicheskii Slovar, Vol. 1, (Moskva: Vostochnaia Literatura, 2006), 366.

${ }^{55}$ The madrasas in Sterlibash were among the most distinguishing ones in Russia by the end of the nineteenth century. They became active centers of the Jadidist (reformist) movement and counted among the leading Islamic educational institutions like Muhammadiyya, Aliyya, or Husainiyya madrasas of the Volga Ural region. Galina M. Yemelianova, Russia and Islam: A Historical Survey, (New York: Palgrave, 2002), 87.

${ }^{56}$ Hamit Algar, "Shaykh Zaynullah Rasulev; The Last Great Naqshbandi Shaykh of the Volga-Ural Region" in Muslims in Central Asia; Expressions of Identity and Change, ed., Jo-Ann Gross, (Duke University Press: Durham and London, 1992), 124.

${ }^{57}$ M. N. Farkhshatov, Narodnoe Obrazovanie v Bashkirii v Poreformennyi Period 60-90 e Gody 19 v. (Moskva: Nauka, 1994), 18; Mahmut G. Mahmudov relates that in prerevolutionary period there were 40 madrasas in Isterlibash and over 600 shakirds which made on third of the over all population and its graduates came to influential positions in Bashkiria as muftis, scholars, teachers, men of letters. Mahmut G. Mahmudov, Sterlibash: Gorzhus Tvoei Sud'boiu, (Ufa: Belaia Reka, 2000), 23.
} 
lacked state funding and protection and the great majority of the madrasas were poor and mudarrises were under-qualified. ${ }^{58}$ On the positive side the shakirds' constant wandering in search of different mudarrises enabled them to get to know the realities of their region and to establish closer contact with the local population and serve their religious needs in case of the lack of a local imam.

The famous phrase that defined Imperial Russia as a "prison of nations" seems misleading considering the fact that the "Muslim prisoners" were freely able to travel to the religious centers of Central Asia to get an Islamic education or to establish their own religious institutions, madrasas, and mosques, even at times sponsored by the Russian officials or rulers themselves. There is more evidence that this phrase was an exaggeration. ${ }^{59}$ One of the best examples of this is seen in Orenburg gubernia when the Russian authorities in the midst of religious repressions in Middle Volga area in the 1740s allowed Tatars to establish their own settlements, mosques and madrasas in a sloboda 15 miles from Orenburg town center.

The madrasas in Isterlibash were overshadowed only by the madrasas of the village of Kargala, founded by Tatars in 1745, upon the invitation of the governor of Orenburg gubernia, Nepliuev. ${ }^{60}$ It was not the only Tatar settlement founded with the special permission of the Russian authorities. In order to populate Orenburg Gubernia post-Nepliuev Russian local authorities continued to invite Tatars to settle in the region. ${ }^{61}$ In any case Kargala, possibly because of its proximity to Orenburg town center was the most famous Tatar settlement founded during this period.

\footnotetext{
${ }^{58}$ Mustafa Ozgur Tuna examines these aspects of Madrasa life in Volga-Ural region in great detail see Mustafa Ozgur Tuna, “Imperial Russia's Muslims; Inroads of Modernity” (PhD diss., Princeton University, 2009), 55-58

${ }^{59}$ This is not to say that Muslims of Russia were as free and privileged as, for example, the Christians of the Ottoman Empire.

${ }^{60}$ PSZ. v. 12, No: 8893. The law permitted Tatars to enjoy religious freedoms and to establish stone mosques.

${ }^{61}$ Willard Sunderland, Taming the Wild Field: Colonization and Empire on the Russian Steppe (Ithaca, N.Y.: Cornell University Press, 2004), 76-77.
} 
Nepliuev was convinced that Muslim Tatars could help Russia develop trade relations with the Central Asian cities and khanates. He, in a remarkable tone reflecting Russian officials' views of Tatars, stated "I sent charters beyond Russia, inviting Kirgizes, Khivans, Tashkentians, Kashgarians, Turkmens and Bukharans to conduct trade.... In this capacity I relied on Mohammedans, Tatars of Seitov sloboda; these people (Tatars) can be blinded with greed and I generously rewarded them and promised to shower them gifts in case they succeeded in their mission. They so zealously worked through regions that as of 1745 we started a lucrative business in Orenburg."62 Russian authorities rightly believed that these Tatars of Kargala could play an active role in the growing economy of the region and interregional trade. It truly did fulfill expectations in this context but it also achieved something the Russian authorities in the region could not foresee: it became an intellectual and educational center for the Muslim youth and scholars for the rest of Imperial Russian history.

From the very beginning Tatars of Kargala were allowed by the Russian authorities in the region to construct their sobornoe (stone) mosque in 1745 and they created an educational complex within the confines of the mosque. The first madrasa was founded next year in 1746 . By the year 1802 there were as many as 5 madrasas and four maktabs attached to the complex of the first mosque of Kargala. It was reformed as a posad (suburb) in 1784 by a Senate decree and declared to be a ratusha (merchants' council), ${ }^{63}$ thus further confirming Tatars' dominant position in international trade between Russia and Central Asia.

\footnotetext{
${ }^{62}$ Rustem Basyrov and Svetlana Basyrova, "Tatarskoe Kupechestvo v Rossiisko-Aziatskoi Torgovle v 18 Stoletii” in Bel'skie Prostory, No. 2, 2005. Available online at http://www.hrono.ru/text/2005/basyr02_05. html accessed on 20 November 2010

${ }^{63}$ PSZ, v.. 22, No. 16089.
} 


\section{Efforts to Convert Peoples of the Volga-Ural Region}

The major problem for Islam in Russia until the reign of Catherine the Great was the lack of legal protection. The religious endowments had no security and their property could be confiscated at the whim of a Russian official in the region. The risk of confiscation prevented, or at least slowed down, the development of Islamic institutions in Bashkiria, although in comparison with the Middle Volga Tatars, Bashkirs did experience a great deal of religious freedom. ${ }^{64}$ The blossoming of Islamic institutions played a determining role in the defense of the ethnic identity against the onslaught of the Russian authorities, as Chernavskii indicated. $\mathrm{He}$ argued that Mordvins and Chuvash unlike Tatars and Bashkirs showed much less resistance to the Russian attempts of proselytization since both of them were pagans (Iazychniki) and therefore lacked a systematically formed catechism which would have boosted worshippers' dedication to their pagan religion. ${ }^{65}$

Catherine's predecessors Anna and Elizabeth carried out this last attempt to convert Russia's Muslims. They were ardent Orthodox Christians and were rather keen on following in the footsteps of Peter the Great to convert non-Orthodox people even at the risk of alienating them and wasting their potential uses for Imperial Russia.

The Office of New Converts' Affairs (Kontora Novokreshchenykh Del') was established by the Holy Synod in 1731 in Sviazhsk-Bogorodits monastery with the aim of spreading Christianity among inovertsy of Kazan Gubernia. Andreas Kappeler argues that the office was founded not on the initiative of the Russian church, because the church had lost its political power and become an instrument of the state, but rather on the initiative of unbendingly

\footnotetext{
${ }^{64}$ The law on 22 June 1744 ordered the destruction of 418 of 556 Mosques in Volga region. Those mosques constructed before the conquest of Kazan in 1552 were spared. PSZ, v. 12, No. 8978

${ }^{65}$ Nikolai Chernavskii, "Orenburgskaia Eparkhiia v Proshlom i Nastoiashchem" in Trudy Orenburgskoi Uchenoi Arkhivnoi Kommissii Vypusk 1 (Orenburg: 1900), 105.
} 
westernizing Russian rulers. Peter the Great and his immediate successors dreamed of bringing western civilization. "Behind the change stood new goals of westernization and of leveling and systematizing Russia's complex socio-cultural relationships"

A branch of the office was opened in Nagaibak fortress in Bashkiria as well. ${ }^{67}$ In this center inovertsy of Bashkiria were accepted into Christianity and there were cases of attempts to convert Bashkirs forcefully into Christianity. ${ }^{68}$ In this context the Ukaz of 20 February 1744 by the Imperial Senate decreed the destruction of newly constructed mosques where Orthodox population was settled in Bashkiria and banned their reconstruction. This law reinforced the earlier law that required official permission for the construction of mosques and schools in Bashkiria. $^{69}$ These efforts to contain the influence of Islam in Bashkiria by the authorities were largely unsuccessful and at every opportunity the efforts of Office of New Converts' Affairs were undermined, and those who converted to Christianity were harassed. During the 1735-1740 war nearly 300 households of New Converts were destroyed. ${ }^{70}$ The vice governor of Orenburg Gubernia, P. D. Aksakov, a practical minded administrator vigorously opposed the destruction of mosques in Bashkiria since, he feared, Bashkirs could rise again and cause so many security problems for the Russians in the region. Ignoring Aksakov's point of view to a degree, the Imperial Senate decreed to halt construction of mosques in the region. ${ }^{71}$

\footnotetext{
${ }^{66}$ Andreas Kappeler, "Czarist Policy toward the Muslims of the Russian Empire" in Muslim Communities Reemerge: Historical Perpectives on Nationality, Politics, and Opposition in the Former Soviet Union and Yugoslavia, ed., Andreas Kappeler, Gerhard Simon and Georg Brunner, (Durham: Duke University Press, 1994), 146.

${ }^{67}$ N. M. Kulbakhtin, \& Iu. N. Sergeev, "Religioznaia Politika Tsarizma v Bashkirii" in Sotsialno-Ekonomicheskoe Razvitie i Klassovaia Borba na Iuzhnom Urale i v Srednem Povolzhe Dorevoliutsionnyi Period ed., I. G. Akmanov, (Ufa: Bashkirskii Universitet, 1988), 38

${ }^{68}$ A. P. Chuloshnikov, Vosstanie 1755 g. v Bashkirii, (Izdatel'stvo Akademii Nauk SSSR, 1940), 48.

${ }^{69}$ PSZ. v. 12, No. 8875

${ }^{70}$ Faizulkhak Islaev, Vosstanie Batyrshi god 1755, (Kazan: Fen, 2004), 30.

${ }^{71}$ PSZ Seri 2, Volume 3 pp. 490-491
} 
The Russian state had neither resources nor enough personnel to enforce a full scale Christianization of Bashkirs because the Office of New Converts' Affairs was operating with a limited budget and with very few men. On the other hand the governor of Orenburg gubernia, Nepliuev, was a pragmatic administrator who opposed the use of force in the region for fear of inciting another Bashkir rebellion and losing commercial contacts with central Asia, a vital link for the economic well being of the region. The Orenburg defensive line had effectively isolated Bashkirs within the Russian empire but their warlike potential was still alive. ${ }^{72}$ Nepliuev was not alone in his convictions. Those Russian officials, Tevkelev and Rychkov, who knew the realities of the region, also opposed the use of force. ${ }^{73}$ Accordingly the Russian state's assimilationist policy in Orenburg region was half-hearted and lacked determination.

\section{The Batyrsha Incident, 1755-1756}

As was argued by A. B. Iunusova, during the seventeenth and eighteenth centuries, Islam became an additional factor in the formation of Bashkir ethnic consciousness and heavily influenced ethno-cultural consolidation of Bashkir identity. ${ }^{74}$ During this period Islam quite effectively, if not totally, entrenched itself in the daily and social life of Bashkirs. Marriages, social and individual relations were all determined by the rules of Islam. The most visible evidence of this impact was seen in the garments of women who increasingly adopted Islamic tesettur (veiling; the influence of Tatars was undeniable) in the rituals relating to birth, death, burial, circumcision of boys, the Islamic festivals like the celebration of the end of the fasting on

\footnotetext{
${ }^{72}$ Kazakhsko-Russkie Otnoshenie v 16-18 Vekakh: Sbornik Dokumentov i Materialov, (Alma Ata: Izdatel'stvo Akademii Nauk Kazakhskoi ASSR, 1961), 341.

${ }^{73}$ Kazakhsko-Russkie Otnoshenie v 16-18 Vekakh: Sbornik Dokumentov i Materialov, (Alma Ata: Izdatel'stvo Akademii Nauk Kazakhskoi ASSR, 1961), 573

${ }^{74}$ A. B. Iunusova, Islam v Bashkortostane, (Moskva: Logos, 2007), 25. 
the first day of Shevval of Islamic calendar, Qurban (slaughter) and Mewlid ${ }^{75}$ were closely observed. Visiting the tombs of the Muslims saints buried in Bashkiria gained popularity. ${ }^{76}$ As Islam slowly penetrated to socio-economic aspects of the Bashkir society, religious figures came to fore. Muslim scholars' leverage increased and their leadership potential rose. It is not surprising that the leader and ideologue of the Bashkir rebellion of 1756 was a mudarris, a man called Abdullah Aleev, more popularly known as Batyrsha. He was born between 1710 and 1715. His ethnic background is a matter of speculation. He became the amateurish military leader of a purely religious Bashkir rebellion in 1755-1756. At least where he studied is well known. He attended a madrasa in Kazan Gubernia and studied under a Tatar Mullah called Abd ar-Rakhman in the village Taisuga and then moved to the Tatar village Tashkichu and studied under Abduseliama Uraev. His madrasa education lasted 12 years from 1734 to 1744 . Once he completed his madrasa education he started working as mudarris (Professor of Madrasa) in Orenburg region; first in Osin doroga then in Isetsk province, east of Orenburg Gubernia. Finally he managed to establish his own madrasa in a Mishar village, Karyshbash in Sibir Doroga, and educated Tatar, Bashkir and Mishar youth. Thanks to his long years as a madrasa student he mastered Islamic law (Sharia) and Islamic literature. As his popularity rose he was invited by the Russian officials in Ufa Provincial Chancellery to write his fatwas (judicial opinions) in issues relating to Muslim population in the region. He failed, however, to be an

\footnotetext{
${ }^{75}$ The Mewlid (literally means birth) ritual is not one of the classical Arabic Islamic ceremonies. It is considered a bid'a (invention) condemned by more fundamentalist groups. It extols the birth of Muhammad. It was prosed by an Ottoman Turkish poet, Suleiman Chelebi, in the early 1400s. Most possibly Mewlid was not translated into Bashkir language because of the proximity of early Ottoman Turkish and Bashkir dialects.

${ }^{76}$ A. B. Iunusova, Islam v Bashkortostane, (Moskva: Logos, 2007), 26; A. Z. Asfandiiarov widely examines these festivals, marriages, family structures and impact of Islam in the life Bashkirs. A. Z. Asfandiiarov, Semia i Brak $u$ Bashkir v 18 i Pervoi Polovine 19 vv. (Ufa: 1989)
} 
akhun of Sibir doroga because the starshina of the doroga preferred someone else to become akhun. $^{77}$

The story of Batyrsha is quite revealing with respect to the life of a mullah and the situation in Kazan Gubernia during the Christianization campaign of the 1740s. As is understood from his story, the state repression of Muslims in Kazan Gubernia was not universal and mullahs were able to work in the madrasas to educate Muslim youths. The free movement of shakirds from one madrasa to another apparently was not closely restricted and they were able to choose their own mudarris in the madrasas. Also there were no restrictions by the Russian authorities over the curricula of the madrasas. The presence of madrasas evidenced the prosperity of the Muslim community in Kazan Gubernia and its ability to support these madrasas financially. Those mullahs persecuted by the Russian state or who failed to find employment in the Middle Volga region could travel to the Urals, where Bashkirs were the most numerous Muslim group, to establish their own madrasas as was the case for Batyrsha.

It is also important to note that Mullahs, though their influence was rising, were not the dominant social group in Bashkir society because the secular starshina could influence their appointments as the legally recognized state officials for Muslims. This authority caused resentment among the mullahs about the powers of starshinas over mullahs. As he made clear in his program for the rebellion against the Russian authority, Batyrsha did not spare starshinas as well and condemned their interference into matters relating to sharia law and demanded such matters be left to ulama. ${ }^{78}$ So the dualism in leadership over Bashkir society led to the clash of two groups. Batyrsha's attempt to appear as the leader of the rebellion was a challenge to the

\footnotetext{
${ }^{77}$ S. M. Vasil'ev, Stranitsy Istorii Bashkirii, (Ufa: 1974), 26-27; Allen J, Frank is mistaken when claiming Batyrsha was appointed as akhun by the Russian authorities in Ufa. Allen J. Frank, Islamic Historiography and Bulghar Identity Among the Tatars and Bashkirs of Russia (Leiden: Brill, 1998), 45; Batyrsha's failure to become an akhun is cited in S. M. Vasil'ev, Stranitsy Istorii Bashkirii, (Ufa: 1974), 27.

${ }^{78}$ S. M. Vasil'ev, Stranitsy Istorii Bashkirii, (Ufa: 1974), 28
} 
authority of the starshinas within the Bashkir society as well since Batyrsha was in a position to create an ideological program for the Muslims of the region and could appeal to greater masses than starshinas could dream of.

As Batyrsha stated in his appeal to the empress Elizabeth, the Russian rule in the region disappointed all Muslims and created a backdrop for their alliance against the Russian state. In his long travels through the region he came across the opinions among Tatars and Mishars to form an alliance with the Bashkir groups in case Bashkirs decided to rise against the state. ${ }^{79}$ The only reliable alliance of such diverse peoples could be formed by a man of religion rather than by a man representative of exclusive tribes. There was also hope of concluding an alliance with the Kazakhs of Middle Horde whose seasonal migrations had been severely restricted by the Russian authorities in the areas near Ishim River of south eastern Bashkiria, and Batyrsha believed that Bobyls and Teptiars could join a rebellion as well. ${ }^{80}$

The other advantage of a mullah over a starshina is that while starshinas represented their own clans, tribes or ethnic groups, a mullah could appeal to all the Muslims peoples of the region. Since they all belonged to Sunni school of Islam and they shared the same ethnicity, a mullah's revolutionary appeal could be more universal than a local starshina. The acceptance of their appeal by the Bashkirs is an indicator that Bashkirs' Islamic sentiments had already taken root and by neglecting Batyrsha's dubious ethnic background they vigorously embraced his call for arms.

The direct reason for the outbreak of the rebellion was the abolition of Iasak in Bashkiria in 1754, which the Bashkirs interpreted as a violation of their votchina rights and a loss of status, and the imposition of salt tax on Bashkirs which they had so far freely used. In fact with this

\footnotetext{
${ }^{79}$ Pismo Batyrshi Imperatritse Elizavete Petrovne, (Ufa: Ufimskii nauchnyi tsentr RAN, 1993), 83 and 85.

${ }^{80}$ A. P. Chuloshnikov, Vosstanie 1755 g. v Bashkirii, (Izdatel'stvo Akademii Nauk SSSR, 1940), 77 
new tax, even though Iasak collection was terminated Bashkirs were paying more than earlier. The fermentation of the new uprising began in southern Bashkiria. Bashkirs of Nogai doroga appealed to those Bashkirs of Sibir doroga where Batyrsha was serving at the time. Rebellious Bashkirs realized the fact that they had no chance against the Russians alone, so they decided to find a respected leader who could unite other non-Russian Muslim nationalities of the region and, perhaps, to enlist the support of neighboring Muslim peoples of Central Asia. The choice fell on Mishar Batyrsha mullah from the village Karyshbash, Sibir doroga.

The rebellion was quickly suppressed thanks to the vigorous measures of Nepliuev, and Batyrsha was captured by the punitive forces and duly sent to St. Petersburg to be jailed in Schlusselburg fortress. The three basic reasons for his failure was his lack of military experience, his inability to unite all Muslims of the region under his banner and the rivalry with traditional Bashkir leaders, the starshinas. He was killed several years later when he attempted to escape from the prison after killing several of his guards, which made him a hero in the eyes of Bashkirs. His memory was kept alive in the folk songs and tales. ${ }^{81}$

\section{Catherine the Great's Policy of Religious Toleration}

The most positive role of the abortive Batyrsha rebellion was the impression that it fostered among higher Russian political circles about the futility of forced conversions. The office of New Converts was finally dissolved several years after being halted after the Batyrsha incident in 1764. It is interesting to note that even though Bashkirs fought in defense of their religion they never declared Jihad against Russians. This might be an indicator that they were

\footnotetext{
${ }^{81}$ V. Pistolenko, Iz Proshlogo Orenburgskogo Kraia, (Oblastnoe Izdatel'stvo: Chkalov, 1939), 80. 
still at the initial stages of their Islamization and they were unaware of the basic Islamic terminology or this term was too much popularized much later.

The state repression of Islam was the most widely hated aspect of Russian imperialism in many ways because Islamic norms and notions were well adapted to the Bashkir culture and it became an integral part of the Bashkir society. So any attack on Islam, any missionary activity even in the most peaceful form raised opposition among Bashkirs. In the legislative commission that Catherine II convened in 1767, one of the most basic demands of Bashkirs together with the problem of land seizures in Bashkiria was religious freedom. Bashkir delegates flatly demanded a grant of religious liberties and they included in their demand list the right to construct mosques, to pray five times a day freely, to have two mullahs for each mosque; one Imam (prayer leader) and one Muadhin (caller for prayer). They stated that these worship houses (dom molitva) were needed because they would pray for the well-being of humanity and for the good health of the Empress. ${ }^{82}$ Indirectly they were trying to say that they were the loyal subjects of her highness. It is clear from their demands that Islam had already been an integral part of their society and culture.

Muslims benefited from the reign of Catherine the Great. To the surprise of the governing elite of Russia, she first abolished the Office of New Converts in $1764^{83}$ and her edict dated 17 June 1773 granted religious freedom to all faiths but in particular it was aimed at Muslims. ${ }^{84}$ The edict forbade the destruction of mosques and promised non intervention in matters relating to religious life. On the other hand it was clear that because of the rising Orthodox population in the region and the successes of the local Russian authorities in

\footnotetext{
${ }^{82}$ N. M. Kulbakhtin, Nakazy Narodov Bashkortostona v Ulozhennuiu Komissiiu 1767-1768 gg. (Ufa: Kitap, 2005), 92-93.

${ }^{83}$ PSZ v. 16 no; 12126; She enacted this law in April 1764. Her abolition of this office is remarkable because she was in power for less than a year after she overthrew her husband Peter III.

${ }^{84}$ PSZ, v. 19, No: 13996
} 
suppressing disturbances, the Russian authorities did not consider the region a part of the frontier and the Bashkirs as dangerous elements. Catherine had immersed herself in the enlightenment debate in Europe and she unlike previous rulers of Russia had a deep interest in the inovertsy. The Russian military was strong enough to defeat potential Muslim rebels and this growing sense of security led Catherine to issue the edict of religious tolerance. It was a political move that indicates the state's pragmatism as well. Catherine's act was not purely due to her dedication to enlightenment ideas but to her imperial visions. By incorporating the Muslim elite into the imperial system she dreamed of strengthening Russia's hands in the Islamic lands beyond Russia's reach. ${ }^{85}$ The creation of such an institution was also the expression of her desire to run the empire on a more institutionalized base.

Considering the Russian efforts to proselytize non-Orthodox populations in Middle Volga region and short-lived attempt to proselytize at least a small segment of the Bashkir society, it can be argued that the Russo-Bashkir struggle took also a religious form. From today's perspective, it seems that while the Russians won the struggle in the military sphere, in the religious sphere Muslims ably defended their distinct identity as Muslims. The Russian government was capable of employing money, privileges, rewards, if all failed, force. It must be, however, stressed that the imperial regime also had a lot of ambivalence and it changed policies repeatedly and made occasional concessions. Muslims on the other hand had only two means; persuasion (sometimes use of economic incentives to force animistic peoples to convert) and trade relations with the non-Russian peoples of the Volga-Ural region. After Peter the Great brought a new dimension to Russian imperial policy toward Asia, a third factor played a

\footnotetext{
${ }^{85}$ Michael Khodarkovsky, "The Conversion of Non-Christians in Early Modern Russia" in Of Religion and Empire, Missions, Conversion, and Tolerance in Tsarist Russia, ed., Robert Geraci and Michael Khodarkovsky, (Ithaca and London: Cornell University Press, 2001), 138.
} 
dramatic role: Muslims of Russia became too valuable for the Russian to conduct their relations with the Central Asian Muslim Khanates. Accordingly frontier war in Bashkiria in the eighteenth century evolved into a struggle of two different cultures where Russians were incapable of defeating their opponents. On the contrary by the end of the century it became clear that Bashkirs were more Islamic than before partly because of the Russian repressions.

The clearest evidence of Russia's defeat in this struggle was the decision to establish the Orenburg Muslim Spiritual Assembly. It was the symbol that Russians could not and would not be able to destroy or assimilate the Bashkirs. On the other hand, it must be stressed that there was not a continuous imperial policy to exterminate Islamic elements in Russia. It is undeniable that some Russian rulers and a few Russian officials were enthusiastic proselytizers but theirs were short lived attempts. The Russian imperial authorities faced the dilemma of converting Bashkirs to Christianity or letting Bashkirs leave on their own in religious matters. Due to the rebelliousness of Bashkirs the second method was the dominant policy. In the same context Firouzeh Mostashari maintains that the Russian state had the same dilemma and that the Russian administration in North Caucasus was bolder in missionary activities where the local resistance was negligible while the rebellious Dagestan and Chechnya were beyond such considerations. ${ }^{86}$

The regime established the Orenburg Muslim Spiritual Assembly in 1788 after Catherine the Great's reforms of the nobility and the townspeople. This was part of her enlightened absolutism, a kind of old-regime corporatism that brought different groups in Russia under government oversight. Mark Raeff described it as 'the well-ordered police state,' a term from the eighteenth century. Such institutions were part of a larger government policy toward most of

\footnotetext{
${ }^{86}$ Firouzeh Mostashari, "Colonial Dilemmas: Russian Policies in the Muslim Caucasus" in Of Religion and Empire: Missions, Conversion, and Tolerance in Tsarist Russia, ed, Robert Geraci (Ithaca and London: Cornell University Press, 2001), 229
} 
the groups of the Russian empire. Muslims of the Russian empire were by no means the only group who received a governmental religious tolerance. Even those Christian groups, Old Believers, who had been persecuted in the past Under Peter I, Anna and Elizabeth were also granted religious freedom, promised free use of their rituals and prayerbooks and those who had fled Russia in the past to Poland, Moldavia and even Turkey were lured back by the government.

Catherine the Great's enlightened despotism produced state toleration for the Muslim communities within the defined boundaries. However her policy of toleration must not be understood as universal toleration of the tsarist state to all religious confessional groups. Certain Christian heretics or atheists were still targeted by the state and they were still subject to prosecution. The Russian state's attempt to bring the Muslim community under the umbrella of the secular state was aimed at better controlling the Muslim community, creating a Muslim ummah (any Muslim community) that would be loyal to the Russian state and employing these loyal Muslims elements in Central Asia to promote Russian interests. ${ }^{88}$

One example of this policy was that while the government tolerated Old Believer heresy, it felt compelled to preserve existing Islamic orthodoxy, however questionable, in the face emerging heretical Islamic views. A certain mullah called Murat Ishapov was denounced to the governor of Orenburg, I. A. Reinsdrop, by the akhun of Seitov sloboda Abdulnasyr Abdusaliamov and a number of mullahs with the accusation that Ishapov had dangerous religious beliefs and disseminated them. In their report they claimed that Ishapov wrote books in

\footnotetext{
${ }^{87}$ Marc Raeff, Imperial Russia, 1682-1825, The Coming of Age of Modern Russia, (New York: Knopf, 1971), 58

${ }^{88}$ Robert D. Crews, "Allies in God's Command; Muslim Communities and the State in Imperial Russia" (PhD diss., Princeton University, 1999), 3.
} 
contravention to Islamic canonical rules and this created anger (vozmushchenie) among the Muslim population.

The governor immediately investigated the issue and the materials which were found in the house of Ishapov were sent to the petitioners who were scholars themselves, to search to find anything heretical in those books. The scholars concluded that he had committed heresy because he attempted to create a new religious law based on the Old Testament, New Testament, and Quran. The Russian authorities clearly collaborated with the Muslim scholars in this issue to avoid any upheaval in the region, fearing that Murat had the potential to become another Batyrsha. Murat and a few of his followers were duly exiled. Reinsdrop was more than careful for the tranquility of his Gubernia and sent his orders to Bashkir, Mishar, and Teptiar starshinas forbidding the release (otpuskat') of pilgrims to visit Biliarsk where the ruins of the Bulghar khanate were found. (Murat had declared that that spot was a sacred place). The persecution of Muslim religious heresy was an application of the government's policy of collaborating with the religious and local Muslim leadership to avoid local crises. ${ }^{89}$ It also showed the limits of religious tolerance on the part of the authorities. As long as religious movements lacked political and destabilizing dimensions, Russian authorities were ready to grant religious tolerance.

The case of Murat Mulla was a proof that Muslim religious life and education must have been regularized and standardized to avoid heresy and currents distasteful to the state.

Establishment of such an institution (the Spiritual Assembly) within the state administration as an extension of the state power to the Muslim population of the region was desirable. The authorities believed that such an institution could also be used to extend the sway of the Russian state beyond the borders of the Russian empire and to Islamize and pacify the "unruly" Kazakhs.

\footnotetext{
${ }^{89}$ I. M. Gvozdikova, Bashkortostan Nakanune i v Gody Krest'ianskoi Voiny Pod Predvaditelskom Pugacheva, (Ufa: Kitap, 1999), 238-243. 
The Russian state with the foundation of an official Muslim religious institution was passing from the stage of repression to the stage of active cooperation and integration of a religion into the political system of the empire.

The imperial decree that announced the foundation of the Orenburg Muslim Spiritual Assembly is the turning point for the Muslim peoples of Russia. ${ }^{90}$ As was mentioned it was not simply the product of Catherine's enlightened despotism. Fortunately she always managed to work with talented and capable officials. One of them was a certain Osip Igel'strom who was originally a Baltic German. He served in the Russian army during the Russo-Turkish wars of 1768-1774 with distinction. He was also the first Russian governor of the newly acquired Crimea and was very successful in integrating the peninsula to the empire by getting the cooperation of the Crimean Tatar nobility. Igel'strom's governing style was to get the support of the local elite without which in his opinion it was impractical to rule and difficult to succeed to establish an effective administration. It was necessary to cooperate with the local Muslim elite to assimilate the Muslim masses. ${ }^{91}$

He was sent to Orenburg as governor in 1784 and one of his first acts was to employ a Bashkir noble, Muhammadzhan Huseinov, as his agent in his relations with the Kazakhs. Muhammadzhan Huseinov after Kutlu-Muhammad Tevkelev was the first non-Russian envoy of the Russians to Kazakhs. Unlike Tevkelev, he remained a Muslim while Tevkelev converted to Christianity bearing the name Aleksei Ivanovich. Igel'strom considered him as a man to be

\footnotetext{
${ }^{90}$ The name of the Assembly may give the impression that it was located in the town of Orenburg. It was in fact located in Ufa. Marjani also misinterprets the name and states that the center of the assembly was in Orenburg. He argues that the Assembly was founded as part of Kuchuk Kaynardji treaty of the Russian Empire with the Ottomans. Sehabeddin Mercani, Mustefadu'l-Ahbar fi Ahval'i Kazan ve Bulgar, (Ankara: Ankara Kultur Merkezi Yayini, 2008), 164; R. Z. Shakurov, ed., Bashkortostan: Kratkaia Entsiklopediia, (Ufa: Nauchnoe Izdatel'stvo, 1996), 630.; This assembly was followed by two other Muslim Assemblies. The first one, Muftiyat of Crimea was founded in 1831 in Bakhchesaray and the other one, Muftiyat of Transcaucasus in 1872 in Baku.

${ }^{91}$ Alan W. Fisher, The Crimean Tatars, (Stanford, Calif.: Hoover Institution Press, 1978), 71.
} 
trusted. So not surprisingly Huseinov became the first mufti of the Spiritual Assembly when it was opened on 4 December $1789^{92}$ and remained in that post until he died in 1824 . His scholarly side, it was argued, remained weak. He was ethnically a Bashkir who was born in a village, Sultanai, near Ufa in 1758. He studied in the madrasas of Kargala village and then in Central Asia and Kabul. He was an adept negotiator and his first valuable service to the Russian state was to persuade Kabardinian rebels to cease fighting against the Russian state. He was also a good organizer and vigorously worked to bring a more formal form of Islam to Kazakhs of the Little Horde among whom religious courts were founded and the same thing was repeated in the Northern Caucasus as well. Muhammadzhan Husainov became the embodiment of the Islamic clergy's victory over the secular Bashkir starshina, none of whom could exert so wide authority from North Caucasia to Kazakhstan.

Muhammadzhan Husainov's efforts to make the Assembly the leading Islamic institution earned him opponents from both starshinas and Russian officials when he attempted to elevate his official status within the Empire. Osip Igle'strom and his successor as governor of Orenburg A. A. Peutling, managed to limit Husainov's ambitions. Officials repeatedly reminded him that his powers were limited to religious matters. ${ }^{93}$ With the initial Russian connivance and support, however, the institution grew by leaps and bound and in 1800, in Orenburg region there were 1921 Muslim religious officials under the supervision of the Assembly. ${ }^{94}$

\footnotetext{
${ }^{92}$ I. G. Akmanov and Aznagul Uruskulov, ed, Bashkirskaia Entsiklopediia, v. 4, (Ufa: Nauchnoe Izdatel'stvo, 2005), 550. The article states that the assembly's main purpose was to control the Islamic clergy.

${ }^{93}$ Danil' D. Azamatov, "The Muftis of Orenburg Spiritula Assembly in the $18^{\text {th }}$ and $19^{\text {th }}$ Centuries: The Struggle for Power in Russia's Muslim Institution," in Muslim Culture in Russia and Central Asia from the 18th to the Early 20th Centuries vol 2, ed., Michael Kemper; Anke von Kügelgen; Dmitriy Yermakov, (Berlin: Schwarz, 1998), 356357.

${ }^{94}$ I. G. Akmanov and Aznagul Uruskulov, ed, Bashkirskaia Entsiklopediia, v. 4, (Ufa: Nauchnoe Izdatel'stvo, 2005), 307.
} 


\section{Bashkir Popular Islam}

While at the official level the Muslims were recognized as a legal group, at a societal level Bashkirs were drawing closer and closer to an Islamic life and making it an integral element of their society. A significant indicator of the penetration of Islam thoroughly into the minds of Bashkirs is evidenced in Bashkir folk songs which had themes of Islam and its role in the daily life of Bashkirs. These songs, dating from the eighteenth and nineteenth centuries, are deeply religious, extensively using Islamic concepts and rituals of death, purification of soul, repentance and appeal for forgiveness. Much less known Islamic angels like Munkar and Nakir are also added into the vocabulary of these songs. ${ }^{95}$

Every man leaves this world. It is final His property cannot help him at all So keep in mind you are mortal, Repent and purify your heart!

Now you are alive,

The soul will leave your body.

Don't be caught off guard,

Repent and purify your heart!

Your body falls ill,

Here comes Azrail

Inheritors try to kill

Repent and purify your heart!

Once you are in the pit

Munkar and Nakir interrogate it

How will you answer them?

Now nobody knows how you are in the pit.

By the beginning of the nineteenth century Islam was a dominant factor in the life of the Bashkirs. In education, for example, the number of religious schools under the Orenburg

\footnotetext{
${ }^{95}$ Islamic eschatology, they are angels who test the faith of the dead in their graves.

${ }^{96}$ Ahmet Suleymanov, ed., Baskurt Edebiyati, v. 1, (Ankara: T. C. Kultur ve Turizm Bakanligi, 1993), 156-157. 
Muslim Spiritual Assembly in Menzelinsk Uezd, Ufa province, increased from 21 in 1820 to 129 by $1868 .^{97}$ Unfortunately the documents of the Assembly about the exact numbers of maktabs and madrasas were lost in fires during the first half of the nineteenth century or were seriously harmed due to the ignorance of the Muslim officials who worked in the Assembly. Accordingly we also do not know the exact number of Bashkir students who attended these schools. And in fact there was no such categorization along the ethnic lines among the Muslims of the Volga Ural region partly due to the fact that intermarriages abounded and it was difficult to determine the ethnic identity of a student.

Another indicator of Islam among the Bashkirs in the nineteenth century was the availability of Bashkir Spiritual leaders among the Muslims of the region. The last great Nakshibandi sheikh of the Volga-Urals, Shaykh Zaynulla Rasulev (1735-1917), was a Bashkir who was portrayed by the Tatar periodical Vaqit "as the spiritual King of his people." He received his first education in his native village's madrasa from Damulla Muhammad Bukhari, a Bukharan scholar. ${ }^{98}$ Since his story is beyond the scope of this dissertation I will not go into details of his life. But what is clear from his life is that the Bashkir lands were the hub of Islamic life which attracted Muslim scholars, mudarrises, and members of ulama from the surrounding regions.

\footnotetext{
${ }^{97}$ M. N. Farkshatov, "Dokumenty Orenburgskogo Magometanskago Dukhovnogo Sobraniia po Istorii Mektebov i Mederese Bashkirii Vtoroi Poloviny 19 v." in Maloizuchennye Istochniki po Istorii Bashkirii, ed., N. M. Gvozdikova, R. G. Kuzeev, Kh. F. Usmanov, (Ufa: 1986), 36.

${ }^{98}$ Hamid Algar tells the story of this remarkable sheikh in great detail. Hamit Algar, "Shaykh Zaynullah Rasulev: The Last Great Naqshbandi Shaykh of the Volga-Ural Region" in Muslims in Central Asia; Expressions of Identity and Change, ed., Jo-Ann Gross, (Duke University Press: Durham and London, 1992), 112-133.
} 


\section{Conclusion}

At the beginning of the nineteenth century Islam and Bashkir ethnic identity were mixed. All Bashkirs were recognized as Sunni Muslims while there was a large group of Tatar Christians (Kriashens). The Russian efforts to proselytize Bashkirs were half-hearted and they always met with strong resistance by these people. Even from among those Bashkirs who were captured and sent to European Russia as slaves during the 1735-1740 war, there were some Bashkirs who managed to escape from captivity and return back to their native lands. The dynamics of Bashkir efforts to preserve their religious identity are still not widely studied. Yet there are clues that they understood Islam and Bashkir identity as inseparable. The patterns of their sedentarization went hand in hand with their Islamization and they mostly struggled against the Russians. After the foundation of the Assembly ${ }^{99}$ a dominant Volga-Tatar community emerged which patronized Islamic scholarly life, and Volga Tatars attempted late in the nineteenth century to create a Tatar cultural empire in the region. In that period, most of the Bashkir efforts to prevent their assimilation were directed against Tatar cultural hegemony. This struggle has lasted to this day and taken political overtones.

\footnotetext{
${ }^{99}$ The foundation of the Assembly meant that it gave an official status to those muftis. These muftis also controlled the budget and they were sometimes generously rewarded by the Russian rulers. The emergence of a lucrative and also politically influential position quite naturally raised ambitions within the Muslim ummah (community of believers) and this brought divisions.
} 


\section{Epilogue}

For the most part of the twentieth century, empires were condemned as evil, repressive, pre-modern, arbitrary and simply 'imperialist'. On the other hand nation states were eulogized as something good, legitimate and representative of modern times. By the end of the last century states based on nations proved much more catastrophic and they were identified with ethnic cleansings, deportations and inter-ethnic violence with varying degrees of intensity. It would be quite erroneous to assume that empires are the organisms that did not have excesses. Imperial rule is prone to deportations, resettlements, colonial wars etc. But it must be stressed that the subject peoples also benefited from such rule as a result of the imperial regimes' inclusive nature, as long as subject peoples adopted imperial rule and proved willing partners of the imperial regimes. ${ }^{1}$

The new Russian imperial historians have stressed that the Muscovite and Imperial Tsars were pragmatic rulers who were flexible enough to incorporate the local elite into service once strong opposition to the Tsarist regime in the newly acquired lands disappeared. Moscow in this respect did not hesitate to work with the Muslim elite as long as they served the purpose. Unlike West European colonial empires, Russian empire proved to be a much less rigid organism in managing the empire in terms of its treatment of the nationalities. The imperial administration was open to gifted peoples of non-Russian nationalities. Although their conversion to Orthodoxy was wished, non-Orthodoxy was not a major impediment for the promotion.

\footnotetext{
${ }^{1}$ Muslim scholars in various parts of the Islamic world noticed this aspect of imperial rule early on. One of the Ottoman Muslim scholars in a conversation with one of the Russian imperial officials in Tbilisi on the eve of the World War I argued: "India is a gifted son of Islam. It is studying in the English high schools; Egypt is an astute child of Islam. It is being educated in administrative sciences in the English schools; Take Caucasia and Turkestan they are two warrior-like sons of Islam they are being educated in the Russian military academies." See Bediuzzaman Said Nursi; Hayati, Mesleki, Tercume-i Hali, (Istanbul: Sozler Yayinevi, 1986), 73
} 
The imperial systems in Europe showed various forms of organization and ideologies. A recent study has argued that multi ethnic gentry dominated the administration of the Russian empire and Russian peasants could be owned as serf by non-Russian, non-Orthodox and even non-Chriatian nobleman. ${ }^{2}$ On the other hand a Muslim Tatar of Middle Volga region or a Bashkir continued to lead their lives as freemen, not owned by a noble. Bashkirs in this respect were no exception to the Russian policy of 'pragmatic flexibility.' Even those who had rebelled in the past were pardoned and were given important posts in their own localities. This policy of amnesty is also an indicator of a self-confident imperial system in which the Tsars sought cooperation rather than revenge. Thanks to this pragmatic flexibility even though the Bashkirs' traditional pastoral economy was devastated, they nevertheless benefited from this rule in other ways.

Bashkiria, as Steinwedel argues, was integrated into the Russian Empire from the 1760s to $1860 \mathrm{~s}$ in three overlapping stages. Steinwedel analyzed integration of a region rather than people. He mostly interpreted the region's history from the Russian perspective and analyzed the Russian state's policies in the region. His book chapter mostly deals with the issue of bringing European culture to Bashkiria but fails to evaluate the impact of that westernization on the Bashkir people. ${ }^{3}$ My essay has focused on the previous period of Russo-Bashkir relations and focused more on the Bashkirs themselves.

My study fits into the new imperial studies where the focus is the native peoples instead of the Russian state or Russian people. Since it is impossible to write a Bashkir history independent of Russian influence because of the long Russian presence, I analyzed the

\footnotetext{
${ }^{2}$ Alexei Miller \& Alfred J. Rieber, ed. Imperial Rule, (Budapest \& New York: CEU Press, 2004), 12

${ }^{3}$ Charles Steinwedel, "How Bashkiria Became Part of European Russia, 1762-1881” in Russian Empire: Space, People, Power, 1700-1930, eds. Jane Burbank, Mark von Hagen \& Anatolyi Remnev, (Indiana University Press: Bloomington and Indianapolis, 2007), 95-124.
} 
interactions between Russian state and Bashkir society. My purpose was to approach a much neglected nationality from a general perspective to treat Russia as an empire composed of many diverse national groups. I realized that Russian rule in the long run was beneficial for Bashkir people because the more Russian state increased its power in the region the more Bashkirs became sedentarized and the more they became institutionalized as a distinct ethnic group once the Russian authorities established Bashkir cantonal system in 1798.

The Russian government's lack of a premeditated policy regarding Bashkiria, aside from extracting as much Iasak as possible, was the shaping feature of their relations with the Bashkirs. Muscovite rulers had conflicting practices: while granting Bashkirs autonomy, they violated this grant in many occasions during the seventeenth century thereby provoked Bashkir rebellions. Therefore the Russian policy pertaining to the Bashkirs and Bashkir lands during the Muscovite era looks like a hesitation waltz. ${ }^{4}$

These rebellions had a certain formative effect on Bashkirs' identity. As I have argued in my dissertation, Bashkir identity was shaped by their struggle against Russian authority in defense of their economy, autonomy and religion. These features made them different from their Middle Volga brothers, the Volga Tatars. Frontiers are the places where two or more distinct cultures meet and transform each other. This was exactly what happened in Bashkiria, which for more than two hundred years formed Russia's southeastern frontier. The Bashkirs started under Russians as a largely nomadic society. At the end of the period (the first quarter of the nineteenth century) they had become a largely sedentary society. During this process they encountered their Muslim Turkic brothers, Volga Tatars, who escaped from the Russian, initially

\footnotetext{
${ }^{4}$ The phrase "Hesitation waltz' belongs to Marc Raeff. Although he referred to Muscovy in general but I see it as applicable to Bashkir- Russian relations more generally. Marc Raeff, Understanding Imperial Russia, State and Society in the Old Regime, (New York: Columbia University Press, 1984), 11.
} 
punitive, later repressive, policies and other groups. All of them, more or less, left their imprint in the formation of Bashkir identity.

Their encounter with these economically more advanced, culturally more sophisticated, and religiously more devout peoples who formed a role model for Bashkirs had a transforming effect on them. Most of the time, as we have seen in the history of Bashkir rebellions, they clashed over the economic resources of the region. While Tatars, as farmers, demanded more fields, Bashkirs, as nomads, demanded more pasturelands. Yet the Bashkirs helped the Tatars by providing a safe ground for Tatars to retain their cultural integrity.

Because of the Bashkirs' rebelliousness, Russians never managed to impose harsh proselytizing policies in the region. On the other hand, the Russians' contribution to the region and the Bashkirs was to bring a genuine urban culture and prepare conditions that had a transformative effect on Bashkirs. The Russians' effects on the lives of the people proved to be constructive as well as destructive. The old nomadic world of the Bashkirs was effectively crushed by the Russians to a great degree. Yet as noted earlier, nomadic elements survived within the Bashkir society as late as the end of the Romanov dynasty. As Charles Steinwedel argued, Russian imperial policies in Bashkiria attempted to create Bashkir loyalty to the Russian state, to settle nomadic Bashkirs, for which in fact in the eighteenth century there was not a predetermined and comprehensive imperial plan, and to regulate Bashkir services to the state. All of these aspects, in Steinwedel's view with which I concur, played a determining role in the promotion of Bashkirs as a coherent ethnic group with a specific territory. ${ }^{5}$

Bashkirs served in the Russian armies loyally at various times. During the French invasion of Russia, out of 29 irregular cavalry units, 20 of them were Bashkir irregulars. Even if

\footnotetext{
${ }^{5}$ Charles Steinwedel, "Tribe, Estate, Nationality: Changing Conceptions of Bashkir Particularity within the Tsar's Empire" Ab Imperio, 2, (2002), 252.
} 
they were of limited use against the French, they were nevertheless able to suppress domestic unrest in the provinces along Napoleon's route to and from Moscow. ${ }^{6}$ The symbolic meaning of this Bashkir participation in the war against the French was great. Even though Bashkirs earlier fought on the side of the Russians against the Crimean Tatars or Polish, in this patriotic war against a foreign power which had invaded Russia, Bashkir efforts were significant signs of their changed relationship to Russia. This loyalty was not without foundations; in 1798 Russian state finally established a military cantonal system in Bashkiria which became the basis of Bashkir estate system. It was an indicator that Bashkirs were not as nomadic as earlier and they could be attached to a certain permanent location within Bashkiria.

Russian rule in the region finally managed to create a peaceful Bashkir population, which came at a significant price for the Bashkirs. I. G. Akmanov in one his works stated that the price of this transformation for Bashkirs was to end up the third largest ethnic group in their native lands after Russians and Tatars. On the other hand large portions of historical Bashkiria were alienated from the Bashkirs. For example, in 1881, historical Bashkir lands were further divided into two provinces: Ufa and Orenburg. Ufa province at the end of the nineteenth century demographically was dominated by a Muslim population that comprised 55 percent of the overall population. This aspect of the region made it the most Muslim province in the whole empire outside of Central Asia. It was a genuine imperial province with diverse cultures; Muslim Tatars, Mishars, Teptiars, Bashkirs and Orthodox Russians, Ukrainians, Byelorussians, and animist peoples. In Orenburg, however, Baskirs and Tatars were both definitely a minority, which in theory meant Orenburg was no longer a part of Bashkir homeland demographically.

\footnotetext{
${ }^{6}$ Dominic Lieven, Russia against Napoleon: The True Story of the Campaigns of War and Peace, (Newyork: Viking, 2010), 330.
} 
The effects of demographic crisis are still felt in Bashkiria. Bashkirs are still the third largest group in Bashkiria after Russian and Tatars. Another problem that makes the situation even more complicated is that in Bashkiria 72 percent of the Bashkir population considers Bashkir language as their native language. The remaining 28 percent either speaks Tatar or Russian as main language. ${ }^{7}$ The Bashkir government's current policies in Bashkortastan since 1991 have been a constant source of irritation for Tatars. ${ }^{8}$

The period from 1552 to 1824 was a formative period for Bashkirs, at the end of which they were just at the middle of their way to the modernity. Aspects of modernity are represented by literacy, secular intellectual classes, a fully sedentary life, and a growing urban culture. In 1824 none of these aspects was available in the Bashkir society to its full extent. Sedentarization was still developing. Literate groups were slowly emerging but a secular national intellectual class was still missing. In fact intellectual life was mainly dominated in the 1800 s by the more erudite, more international, more cosmopolitan and richer Volga Tatars. Accordingly there emerged a Tataro-Bashkir conflict by the end of the nineteenth century, and Bashkirs took refuge under the umbrella of the Russian autocracy to protect their distinct identity. This was an uneasy alliance but perhaps a necessary one if Bashkirs did not want to merge with the Tatar culture.

This conflict has continued in various ways to this day. The Russian policies played a part in this conflict. The borders of Tatars and Bashkirs were drawn in such a way that today there are more Tatars in Bashkiria than Bashkirs. The situation is more complicated than it may seem. The national question between these two groups never revolves around unification of them. The psychological barrier is too strong to encourage them to think about such a

\footnotetext{
${ }^{7}$ Eastern Europe, Russia and Central Asia, 2003, $3^{\text {rd }}$ edition by Europa Publications Limited (London: Europa, 2003), 359.

${ }^{8}$ Those who are from Tatar origins are recorded in the Bashkir identity certificates as Bashkorts and there is a cultural Bashkordization effort by the government. There are certain restrictions in the state schools to learn Tatar language.
} 
conclusion. This conflict which is mentioned constantly in publications is in fact a continuation of the Bashkirs' national formation which started in earnest in 1552 when the Russian tsar granted them an exceptional client status. ${ }^{9}$

I was in Bashkiria between 2000 and 2002. In one of my interviews with the Bashkort high school principal where I was working as a teacher, he stated that he was against Turkish schools in Bashkortostan for fear, he supposed, that our goal was to Turkify Bashkort youth. He was quite sympathetic to Russians because they were ethnically, linguistically, and culturally different from Bashkirs and there was no likelihood for Bashkir youth's Russification. In this context it has appeared that the current problem of Bashkir national identity has been based on the fear of the similar ethno-cultural elements which seem more sophisticated, though this term can be contested, than that of Bashkirs. So the post-Soviet period in Bashkiria has witnessed a rising Bashkir conservatism in preserving Bashkir identity which is based on near deification of Salavat Iulaev, ironically an anti-Russian Bashkir hero.

\footnotetext{
${ }^{9}$ To grant client status would mean that Russian Tsar recognized Bashkiria as territory beyond Russian central control, not as part of Russia.
} 


\section{WORKS CITED}

"Bumagi Grafa Petra Ivanovicha Panina o Pugachevskom Bunte " Sbornik Russkago Istoricheskago Obshchestva, 6, (1871), 97

"Graf Panin Usmiritel Pugachevshiny, Materialy Dlia Istorii Pugachevskogo Bunta," Russkii Vestnik, 80:3 (1869), 5-168

"Tekst "Otvodnoi Knigi po Ufe" (1591/92-1629 gg.)" in Iz Istorii Feodalizma i Kapitalizma v Bashkirii - Stati ed. S. M. Vasil'eva, (Ufa: 1971), 261-267

A. A. Novoselskii and N. V. Ustiugov, ed., Ocherki Istorii SSSR, Period Feodalizma (Moskva: Izdatel'stvo Akademii Nauk, 1955)

A. A. Spitsyn, "Obrochnye Zemli na Viatke v 17 v. Kazan, 1893" Izvestiia Obshchestva Arkheologii, Istorii i Etnografii pri Kazanskom Universitete, 10, (1892).

A. B. Iunusova, Islam v Bashkortostane, (Moskva: Logos, 2007)

A. I. Dimitriev, "K Istorii Zaural'skoi Torgovli. Bashkiriia pri Nachale Russkoi Kolonizatsii" Permskaia Starina. Sbornik Istoricheskikh Statei i Materialov Preimushchestvenno o Permskom Krae, v. 8,. (Perm: 1900)

A. G. Biishev, Istoriia Bashkirkogo Naroda i Ego Bor'ba za Svobodu, (Ufa: Kitap, 1993),

A. I. Akmanov, Zemelnaia Politika Tsarskogo Pravitelstva v Bashkirii Vtoraia Polovina 16Nachalo 20 vv. (Ufa: Kitap, 2000)

A. I. Akmanov, "Voprosy Bashkirskogo Zemlevladenie v Materialakh Gosudarstvennoi Dumy, 1906-1917 gg. (po Vystupleniiam Musul'manskikh Deputatov)" (Unikal'nye Istochniki po Istorii Bashkortostana: Materialy II Period, Region. Nauch. Prakt. Konf. Ufa, 20 Dek. 2001), 77-86

A. I. Akmanov, Bashkirskoe Zemlevladenie v 19 -Nachale 20 vv. (Ufa: 2000)

A. I. Akmanov, Zemel'nye Otnosheniia v Bashkortostane i Bahkirskoe Zemlevladenie vo Vtoroi Polovine 16-Nachale 20 v. (Ufa: Kitap, 2007)

A. I. Aksenov, R. V. Ovchinnikov and M. F. Prokhorov, comp., Dokumenty Stavki E. I. Pugacheva, Povstancheskikh Vlastei i Uchrezhdenii, 1773-1774 gg. (Moskva: Nauka, 1975)

A. I. Andrushenko, Krest'ianskaia Voina, 1773-1775 gg., Na Iaike, v Priurale, na Urale, i v Sibiri,(Moskva: Nauka, 1969)

A. I. Dobrosmyslov, "Bashkirskii Bunt v 1735, 1736 i 1737 g." in Trudy Orenburgskoi Uchenoi Arkhivnooi Kommissii, no: 8, (Orenburg: 1900), 3-4 
A. I. Dobrosmyslov, Materialy po Istorii Rossii, v.2, (Orenburg: 1900)

A. Kuzembaiyly \& E. Abilev, Istoriia Kazakhstana s Drevneishikh Vremen do 20-kh Godov 20 v. (Almaty: Sanat, 1996)

A. M. Khazanov, Nomads and the Outside World, (Cambridge: Cambridge University Press, 1984)

A. N. Grigorev, "Khristianizatsiia Nerusskikh Narodnostei, kak Odin iz Metodov Natsional'noKolonial'noi Politiki v Tatarii (Polovina 16 v. do Fevralia 1917 g." Materialy po Istorii Tatarii, 1. (Kazan: 1948), 226-285

A. N. Usmanov, "Kinzia Arslanov, Vydaiushchiisia Spodvizhnik Pugacheva" Istoricheskie Zapiski, 71, (1962), 113-133

A. N. Usmanov, "Razvitie Zemledelie v Bashkiri v Tret'ei Chetverti 18 Veka" Iz Istorii Feodalizma i Kapitalizma v Bashkirii, ed., S. M. Vasil'ev and A. N. Usmanov, (Ufa: 1971), 2274

A. N. Usmanov, Dobrovol'noe Prisoedinenie Bashkirii k Russkomu Gosudarstvu (Ufa: Bashkirskoe Knizhnoe Izdatel'stvo, 1982)

A. N. Usmanov, Prisoedinenie Bashkirii k Russkomu Gosudartsvu (Ufa: Bashkirskoe Knizhnoe Izdatel'stvo, 1960)

A. P. Chuloshnikov, "Feodal'nye Otnosheniia v Bashkirii i Bashkirskie Vosstaniia 17 i Pervoi Poloviny 18 vv." in Materialy po Istorii Bashkirskoi Istorii, part 1: Bashkirskie Vosstaniia v 17 i Pervoi Polovine 18 vv. (Moskva\&Leningrad: Izdatel'stvo Akademii Nauk SSSR, 1936), 22-23

A. P. Chuloshnikov, Vosstanie 1755 g. v Bashkirii, (Izdatel'stvo Akademii Nauk SSSR, 1940)

A. V. D. "O Bashkirakh” Orenburgskoe Gubernskie Vedomosti, 41 (1863)

A. Z. Asfandiiarov, "Dobrovolnoe Vkhozhdenie Bashkir v Sostav Russkogo Gosudarstvo", in http://www.bashru-450.narod.ru/stati_2.html accessed on 8 February 2009

A. Z. Asfandiiarov, "Eshche Raz o Kharaktere Prisoedineniia Bashkortostana k Rossii" (Pervye Validovskie Chtenie; Mezhdunarodnaia Nauchnaia Konferentsiia. Vostokovedeniia v Bashkortostane: Istoriia. Kul'tura. 3., Ufa, 22-24 Centiabria 1992 Goda), 9-10

A. Z. Asfandiiarov, "Religioznaia Politika Tsarizma v Bashkirii v Period Feodalizma" in Bashkirskii Krai, part 1, (Ufa, 1991), 3-9

A. Z. Asfandiiarov, Bashkiriia posle Vkhozhdeniia v Sostav Rossii (Vtoraia Polovina 16 Pervaia Polovina 19 v.) (Ufa: Kitap, 2006) 
A. Z. Asfandiiarov, G. A. Gafarov, "Buraevo (Borai)" Bashkirskaia Entsiklopediia, Vol. 1 ed. I. G. Akmanov and Aznagul Uruskulov (Ufa: Nauchnoe Izdatel'stvo, 2005), 566

A. Z. Asfandiiarov, Semia i Brak u Bashkirv 18 i Pervoi Polovine 19 vv. (Ufa: 1989)

A. Zaripova, "O Votchinnom Prave Bashkir na Zemliu” Vatandash, (Mart, 2007). Available at http://www.vatandash.ru/index.php?article=1366 accessed on 14 July 2008

Agnes Kefeli-Clay, "Krashen Apostasy: Popular Religion, Education and the Contest over Tatar Identity, 1856-1917” (PhD diss., Arizona State University, 2001)

Ahmet Suleymanov, ed., Baskurt Edebiyati, v. 1, (Ankara: T. C. Kultur ve Turizm Bakanligi, 1993)

Ake E. Andersson, William Peter Anderson, Börje Johansson, The Economics of Disappearing Distance, (Ashgate: Aldershot Hampshire England; Burlington VT., 2003)

Akty Istoricheskie, 1676-1700, 5 (1842)

Alan W. Fisher, The Crimean Tatars, (Stanford, Calif.: Hoover Institution Press, 1978)

Aleksei I. Miller, "Between Local and Inter-Imperial Russian Imperial History in Search of Scope and Paradigm" Kritika: Explorations in Russian and Eurasian History, 5, (2004), 7-26

Alexandre A. Bennigsen, \& C. Lemercier-Quelquejay, Islam in the Soviet Union, (New York, Praeger, 1967)

Alexandre Bennigsen and Marie Broxup, The Islamic Threat to the Soviet State (New York : St. Martin's Press, 1983)

Alexei Miller \& Alfred J. Rieber, ed., Imperial Rule, (Budapest \& New York: CEU Press, 2004)

Allen J. Frank, Islamic Historiography and "Bulghar" Identity among the Tatars and Bashkirs, (Leiden [Netherlands] ; Boston : Brill, 1998)

Allen J. Frank, Muslim Religious Institutions in Imperial Russia: the Islamic World of Novouzensk District and the Kazakh Inner Horde, 1780-1910, (Boston: Brill, 2001)

Allen J. Frank, Tatar Islamic Texts (Hyattsville, MD: Dunwoody Press, 2008)

Alton Donnelly, "The Orenburg Expedition: Russian Colonial Policies on the Southeastern Frontier, 1734-1740” (PhD diss., University of California, 1960)

Alton Donnelly, The Russian Conquest of Bashkiria, 1552-1740: A Case Study in Imperialism, (New Haven and London: Yale University Press, 1968) 
Anatoly Khazanov, Nomads and the Outside World, 2nd ed., trans Julia Crookendon (Madison: University of Wisconsin Press, 1994)

Anatoly M. Khazanov, "Nomads and Oases in Central Asia" Transition to Modernity: Essays on Power, Wealth, and Belief, ed. Ernest Gellner, John A. Hall, Ian Charles Jarvie,(New York: Cambridge University Press, 1992), 74

Andreas Kappeler, "Czarist Policy toward the Muslims of the Russian Empire" Muslim Communities Reemerge: Historical Perpectives on Nationality, Politics, and Opposition in the Former Soviet Union and Yugoslavia, ed., Andreas Kappeler, Gerhard Simon and Georg Brunner, (Durham: Duke University Press, 1994), 142-156

Andreas Kappeler, The Russian Empire: A Multiethnic History (Harlow: Longman, 2001)

Ann Laura Stoler and Frederick Cooper, "Between Metropole and Colony, Rethinking a Research Agenda" in Tensions of Empire, Colonial Cultures in a Bourgeois World, ed. Frederick Cooper and Ann Laura Stoler, (London: University of California Press, 1997), 1-58

Anna I. Poterpeeva \& V. E. Chetin, Revoliutsionnaia Trudovaia Letopis Iuzhnoural'skogo Kraia; Khrestomatiia Arkhivnykh Dokumentov po Istorii Iuzhnogo Urala, 1682-1918, (Cheliabinsk : Iuzhno-Ural'skoe Knizhnoe Izdatel'stvo, 1980)

Anthony D. Smith, "Structure and Persistence of Ethnie in Montserrat Guibernau." The Ethnicity Reader: Nationalism, Multiculturalism and Migration, 2. edition, ed. John Rex, (Polity Press: Cambridge, 2010), 27

Apollon Kuzmin, Tatishchev, (Moskva: Molodaia Gvardiia, 1981)

Asylguzha Bagumanov, "Salavat Iulaev i Grazhdanskaia Voina 1773-1775 godov" Vatandash, 6, (1998), 93-96

Austin Jersild, "Russia, from the Vistula to the Terek to the Amur," Kritika: Explorations in Russian and Eurasian History 1, (Summer, 2000), 531-546

B. A. Aznabaev, Integratsiia Bashkirii v Administrativnuiu Strukturu Rossiiskogo Gosudarstva (Vtoraia Polovina 16-Pervaia Treti 18 vv.) (Ufa: RIO BashGU, 2005)

B. Kh. Iuldashbaev, Istoriia Formirovaniia Bashkirskoi Natsii Dooktiabrskoi Period, (Ufa: Bashkirskoe Knizhnoe Izdatel'stvo, 1972)

B. O. Dolgikh, Rodovoi i Plemennoi Sostav Narodov Sibiri v 17 Veke (Moskva: Izdatel'stvo Akademii Nauk SSSR, 1960)

Bediuzzaman Said Nursi; Hayati, Mesleki, Tercume-i Hali, (Istanbul: Sozler Yayinevi, 1986) 
Benedict Anderson, Imagined Communities; Reflections on the Origin and Spread of Nationalism revised edition, (Verso: London, 1991)

Boris M. Mironov, The Social History of Imperial Russia, 1700-1917, v.1, (Boulder; Colorado: Westview Press, 2000)

Boris Nolde, "Usmirenie Bashkirii” Vatandash, 2, (2000), 91-120

Brian J. Boeck, Imperial Boundaries, Cossack Communities and Empire-Building in the Age of Peter the Great,(Cambridge: Cambridge University Press, 2009)

Brian L. Davies, Warfare, State and Society on the Black Sea Steppe, 1500-1700 (London and New York: Routledge, 2007)

C. A. M. Hennessy, The Frontier in Latin American History (Albuquerque: University of New Mexico Press, 1978)

Carol Belkin Stevens, Soldiers on the Steppe: Army Reform and Social Change in Early Modern Russia,(DeKalb, Northern Illinois University Press, 1995)

Caroline Humphrey and David Sneath, The End of Nomadism?: Society, State, and the Environment in Inner Asia (Durham: Duke University Press, 1999)

Charles A. Riess, "The History of the Kalmyk Khanate to 1724" (PhD diss., Indiana University, 1983)

Charles Steinwedel, "How Bashkiria Became Part of European Russia, 1762-1881" in Russian Empire: Space, People, Power, 1700-1930, eds. Jane Burbank, Mark von Hagen \& Anatolyi Remnev, (Indiana University Press: Bloomington and Indianapolis, 2007), 94-124

Charles Steinwedel, "Invisible Threads of Empire: State, Religion, and Ethnicity in Tsarist Bashkiria, 1773-1917” (Columbia University, 1999 Ph.D.)

Charles Steinwedel, “Tribe, Estate, Nationality? Changing conceptions of Bashkir Particularity within the Tsar's Empire" Ab Imperio: Theory and History of Nationalities and Nationalism in the Post-Soviet Realm, 2 (2002), 249-278

Christian Noack, Muslimischer Nationalismus im Russischen Reich: Nationsbildung und Nationalbewegung bei Tataren und Baschkiren, 1861-1917 [Muslim Nationalism in the Russian Empire: Nation-Building and National Movements among the Tatars and Bashkirs, 1861-1917]. (Stuttgart: Franz Steiner Verlag, 2000)

D. A. Korsakov, Iz Zhizni Russkikh Deiatelei 18 v. (Kazan: 1891)

D. A. Safonov, Nachalo Orenburgskoi Istorii (Sozdanie Orenburgskoi Gubernii v Seredine 18 v.) (Orenburg, 2003) 
D. Anuchin, "Pervye Uspekhi Pugacheva i Ekspeditsiia Kara" in Voennyi Sbornik, 6 (1869), 540

D. Chidester, Savage Systems: Colonialism and Comparative Religion in Southern Africa, (Charlottesville: University of Virginia Press, 1996)

D. Iu. Arapov, "Pervyi Russkii General Musulmanin Kutlu-Mukhammed Tevkelev" Sbornik Russkogo Istoricheskogo Obshchestva, 5, (2002), 32-37

D. N. Sokolov,"Opyt Razbora Odnoi Bashkirskoi Letopisi” Trudy Orenburgskoi Uchenoi Arkhivnoi Kommissii Part 4, (1898), 45-46

D. Zh. Valeev, Istoriia Bashkirskoi Filosofii i Obshchestvenno-Politicheskoi Mysli: Osnovnye Tendentsii Razvitiia (Ufa: Kitap, 2001)

Damir M. Iskhakov, Rasselenie i Chislennost' Tatar v Povolzhsko-Priural'skoi IstorikoEtnograficheskoi Oblasti v 17-19vv. (Moskva: 1980)

Daniel H. Usner, Indians, Settlers \& Slaves in a Frontier Exchange Economy: The Lower Mississipi Valley before 1783 (Chapel Hill and London: University of North Caroline Press, 1992)

Daniel Power, "A. Frontiers: Terms, Concepts and the Historians of Medieval and Early Modern Europe" Frontiers in Question; Eurasian Borderlands, 700-1700, ed. Daniel Power and Naomi Standen, (London: Mc Millan Press, 1999), 1-12

Daniel R. Brower and Edward J. Lazzerini, eds., Russia's Orient: Imperial Borderlands and Peoples, 1700-1917 (Bloomington: Indiana University Press, 1997)

Danielle M. Ross, "In Dialogue with the Shadow of God: Imperial Mobilization, Islamic Revival and the Evolution of an Administrative System for the Tartars, Bashkirs and Mishars of 18thcentury Russia," (M.A. Thesis, University of Madison Wisconsin, 2007)

Danil D. Azamatov, "Russian Administration and Islam in Bashkiria $\left(18^{\text {th }}-19^{\text {th }}\right.$ Centuries)" Muslim Culture in Russia and Central Asia from the 18th to the Early 20th Centuries vol. 1, ed., Michael Kemper, Anke von Kugelgen and Dmitriy Yermakov, (Berlin: Klaus Schwarz Verlag, 1998), 91-111

Danil' D. Azamatov, "The Muftis of Orenburg Spiritual Assembly in the $18^{\text {th }}$ and $19^{\text {th }}$ Centuries: The Struggle for Power in Russia's Muslim Institution," Muslim Culture in Russia and Central Asia from the 18th to the Early 20th Centuries vol 2, ed., Michael Kemper; Anke von Kügelgen; Dmitriy Yermakov, (Berlin: Schwarz, 1998), 355-384

Darshini Anna de Zoysa, The Great Sandy River: Class and Gender Transformation among Pioneer Settlers in Sri Lankas Frontier, (Amsterdam: Spinhuis, 1995) 
David F. Burg, A World History of Tax Rebellions: An Encyclopedia of Tax Rebels, Revolts, and Riots from Antiquity to the Present (New York: Routledge, 2004)

David S. Van Der Oye, Russian Orientalism: Asia in the Russian Mind from Peter the Great to the Emigration, (New Haven \& London: Yale University Press, 2010)

Devin A. DeWeese, Islamization and Native Religion in the Golden Horde: Baba Tükles and Conversion to Islam in Historical and Epic Tradition, (University Park: Pennsylvania State University Press, 1994)

Dina Mustafina, "Materialy o Bashkirskom Vozmushchenii 1735 Goda" Gasyrlar Avazy, 3/4 (1999) available at

http://www.archive.gov.tatarstan.ru/magazine/go/anonymous/main/?path=mg:/numbers/1999_3 4/02/02_2/ accessed on 23 March 2009

Dominic Lieven, Russia against Napoleon: The True Story of the Campaigns of War and Peace, (Newyork: Viking, 2010)

E. I. Indova, A. A. Preobrazhenskii and Iu. A. Tikhonov, "Narodnye Dvizhenie v Rossii 17-18 vv. i Absoliutizm" in Absoliutizm v Rossii, 17-18 vv. Sbornik Statei, ed. Nikolai M. Druzhinin, (Moskva: Nauka, 1964), 77.

E. I. Zaozerskaia, "Begstvo i Otkhod Krest'ian v Pervoi Polovine XVIII Veka" in $K$ Voprosu o Pervonachal'nom Nakoplenii v Rossii (XVII-XVIII vv.), (Moskva: Izdatel'stvo Akademii Nauk SSSR, 1958), 144-188

E. Koutaissoff, "The Ural metal Industry in the Eighteenth Century" The Economic History Review, New Series, v. 4, no: 2 (1951), 253.

Eastern Europe, Russia and Central Asia, 2003, $3^{\text {rd }}$ edition by Europa Publications Limited (London: Europa, 2003)

Eduardo Duran and Bonnie Duran, Native American Postcolonial Psychology (Albany: State University of New York Press, 1995)

Edward J. Lazzerini, "Volga Tatars in Central Asia, $18^{\text {th }}-20^{\text {th }}$ Centuries: From Diaspora to Hegemony" in Central Asia in Historical Perspective, ed. Beatrice Manz (Boulder: Westview Press, 1994), 88

Edward Lazzerini, Volga Tatars in Central Asia 18-20 Centuries: From Diaspora to Hegemony, (Washington, D.C. : National Council for Soviet and East European Research, 1993)

Ernest Gellner, "Patrons and Clients" Patrons and Clients in Mediterranean Societies ed., Ernest Gellner and John Waterbury, (London: Duckworth, 1977), 1-6 
Ernest Gellner, Muslim Society, (Cambridge: Cambridge University Press, 1981)

Ethel Sara Wolper, Cities and Saints: Sufism and the Transformation of Urban Space in Medieval Anatolia (University Park: The Pennsylvania State University Press, 2003)

F. A. Ishkulov. ed., Istoriia Gosudarstva i Prava Bashkortostana, Part 1 (Ufa: Kitap, 1996)

F. Gumerov, “Zakony Rossiiskoi Imperii o Bashkirskikh Zemliakh” Vatandash, 6, (1998), 67-74

F. Gumerov, “Zakony Rossiiskoi Imperii i Kolonizatsiia Bashkortostana”, Vatandash, 4, (1998), $167-176$

F. Kh. Gumerov, compiler, Zakony Rossiiskoi Imperii o Bashkirakh, Mishariakh, Teptiariakh i Bobyliakh (Ufa: Kitap, 1999)

F. Kh. Gumerov, ed., Khrestomatiia po Istorii Bashkortostana Dokumenty i Materialy s Drevneishikh Vremen do 1917 Goda. Volume 1, (Ufa: Kitap, 1996)

F. L. Shakurova, Bashkirskaia Volost' i Obshchina v Seredine 18 - v Pervoi Polovine 19 Veka, (Ufa, 1992)

F. N. Kireev, compiler, Kazakhsko-Russkie Otnosheniia v XVI-XVIII vekakh; Sbornik Dokumentov i Materialov (Alma-Ata: Izd-vo Akademii nauk Kazakhskoi SSR, 1961)

F. N. Kireev, et.al., Kazakhsko-Russkie Otnosheniia v 16-18vv., (Alma-Ata: Izdatel'stvo Akademii Nauk Kazakhskoi SSR, 1961)

Faizulhak Islaev, Vosstanie Batyrshi god 1755, (Kazan: Fen, 2004)

Fatemeh E. Moghadam, From Land Reform to Revolution: The Political Economy of Agricultural Development in Iran, 1962-1979, (London; New York: Tauris Academic Studies, 1996)

Firouzeh Mostashari, "Colonial Dilemmas: Russian Policies in the Muslim Caucasus" Of Religion and Empire: Missions, Conversion, and Tolerance in Tsarist Russia, ed, Robert Geraci (Ithaca and London: Cornell University Press, 2001), 229-249

Firouzeh Mostashari, On the Religious Frontier: Tsarist Russia and Islam in the Caucasus (London: I.B. Tauris, 2006)

Francine Hirsch, Empire of Nations: Ethnographic Knowledge \& The Making of the Soviet Union, (Ithaca: Cornell University Press, 2005)

Fred Beake, Ravil' Bukharaev, trans. The Story of Joseph / Kissa'i Yusuf (Folkestone, UK: Global Oriental, 2010) 
Fred W. Bergholz, The Partition of the Steppe: The Struggle of the Russians, Manchus, and the Zunghar Mongols for Empire in Central Asia, 1619-1758, A Study in Power Politics (New York: Peter Lang Publishing, 1993)

G. N. Garustovich, "Rasprostranenie Islama v Iuzhno-Ural'skom Regione" in Problemy Dukhovnoi Kul'tury Tiurskikh Narodov SSSR, (Ufa: 1991)

G. A. Mikhaleva, "Seitovskii Posad Orenburga i Ego Rol' v Razvitii Russko-Sredenaziatskii Torgovli" Obshchestvennyi Nauki v Uzbekistane, v. 12, (1980), 39-42

G. A. Mikhaleva, Torgovye i Posol'skie Sviazi Rossii so Sredne Aziatskami Khanstvami cherez Orenburg, (Vtoraia Polovina 18 - Pervaia Polovina 19v.), (Tashkent: Izdatel'stvo FAN Uzbekskoi SSSR, 1982)

G. B. Faizov, Gosudarstvenno-Islamskie Otnosheniia v Povolzhe i Priurale, (Ufa: 1995)

G. F. Gudkov, Iz Istorii Iuzhnoural'skikh Gornykh Zavodov 18-19 Vekov, (Ufa: Bashkirskoe Knizhnoe Izdatel'stvo, 1985)

G. G. Kosach, Gorod na Styke Dvukh Kontinentov; Orenburgskoe Tatarskoe Menshinstvo i Gosudarstvo (Moskva: 1998)

Galina M. Yemelianova, Russia and Islam: A Historical Survey, (New York: Palgrave, 2002)

George Vernadsky and Michael Karpovich, A History of Russia: The Tsardom of Moscow 15471682 (New Haven: Yale University Press, 1959)

Grigorii Kosach, "A Russian City between Two Continents: The Tatars of Orenburg and State Power" in Russia at a Crossroads: History, Memory and Political Practice, ed., Nurit Schleifman, (Frank Cass; London, 1998), 33-88

Hamit Algar, "Shaykh Zaynullah Rasulev: The Last Great Naqshbandi Shaykh of the Volga-Ural Region" Muslims in Central Asia; Expressions of Identity and Change, ed., Jo-Ann Gross, (Duke University Press: Durham and London, 1992), 112-133

Herbert H. Kaplan, Russia and the Outbreak of the Seven Years' War, (Berkeley: University of California Press, 1968)

Howard Lamar \& Leonard Thompson, ed. The Frontier in History: North America and Southern Africa Compared (New Haven: Yale University Press, 1981)

I. Bikkulov, "Uchrezhdenie Ufimskoi Provintsii v Nachale 18 Veka" Vatandash, 10, (2006), available at http://www.vatandash.ru/index.php?article=332 accessed on 14 July 2007

I. Debu, Topograficheskoe i Statisticheskoe Opisanie Orenburgskoi Gubernii v Nyneshnem eia Sostoianii, (1837) 
I. G. Akmanov and Aznagul Uruskulov, ed, Bashkirskaia Entsiklopediia, v. 1 (Ufa: Nauchnoe Izdatel'stvo, 2005)

I. G. Akmanov and Aznagul Uruskulov, ed, Bashkirskaia Entsiklopediia, v. 2 (Ufa: Nauchnoe Izdatel'stvo, 2005)

I. G. Akmanov and Aznagul Uruskulov, ed, Bashkirskaia Entsiklopediia, v. 3 (Ufa: Nauchnoe Izdatel'stvo, 2005)

I. G. Akmanov and Aznagul Uruskulov, ed, Bashkirskaia Entsiklopediia, v. 4, (Ufa: Nauchnoe Izdatel'stvo, 2005)

I. G. Akmanov, "Bashkirskie Vosstanie 1704-1711," Sbornik Nauchnykh Rabot Aspirantov Istoricheskogo Fakul'teta MGU, (1963), 124-153

I. G. Akmanov, "Istoricheskie Predposylki Sovmestnoi Borby Bashkirskogo i Russkogo Narodov v Krest'ianskoi Voine 1773-1775 gg.” In Narody v Krest'ianskoi Voine 1773-1775 gg. ed. V. I. Buganov, (Ufa:1977), 50-57

I. G. Akmanov, "Iz Istorii Orenburgskoi Ekspeditsii” in Ocherki Istorii Dorevoliutsionnoi Rossii,v.1 ed. R. V. Filippov (Ufa: Bashkirskii Gos. Universitet, 1972), 90-106

I. G. Akmanov, "Novyi Dokument o Nachale Bashkirskogo Vosstaniia 1735-1740 gg." Iuzhnoural'skii Arkheograficheskii Sbornik, no: 2, (Ufa: 1976)

I. G. Akmanov, "Organizatsiia Orenburgskoi Ekspeditsii i Nachalo Vosstaniia 1735-1740 godov" in Ocherki Istorii Dorevoliutsionnoi Rossii, v. 2, ed. R. V. Filippov (Ufa: Bashkirskii Gos. Universitet, 1975), 101-141

I. G. Akmanov, "Razvitie Zemledeliia u Bashkir v Pervye Veka Posle Prisoedineniia k Rossii i Politika Tsarskogo Pravitelstva po Zemelnomu Voprosu" XXVI S'ezd KPSS i Problemy Agrarnoi Istorii SSSR (Sotsial'no-Politicheskoe Razvitie Derevni), (Ufa: Bashkirskoe Knizhnoe Izdatel'stvo, 1984), 475-484

I. G. Akmanov, "Vosstanie 1662-1664 gg. - Pervoe Massovoe Dvizhenie v Bashkirii" Krest'ianstvo i Krest'ianskoe Dvizhenie v Bashkirii v 17 - Nachale 20 vv. ed., Kh. F. Usmanov, (Ufa: 1981), 45-67

I. G. Akmanov, "O Nalogakh i Povinnostiakh Bashkir v 17-Nachale 18 vv." Voprosy Agrarno Istorii Urala i Zapadnoi Sibiri, ed., F. S. Govoroi, (Sverdlovsk: UGU, 1966), 99-105

I. G. Akmanov, Bashkiriia v Sostave Rossiiskogo Gosudarstva 17-Pervoi Polovine 18 Veka (Sverdlovsk: Izdatel'stvo Ural'skogo Universiteta, 1991)

I. G. Akmanov, Bashkirskie Vosstaniia (Ufa: Kitap, 1993) 
I. G. Akmanov, Bashkirskie Vosstaniia 17-Pervoi Treti 18 v. (Ufa: Bashkirskie Gosuniversitet, 1978)

I. G. Akmanov, Bashkirskoe Vosstanie 1735-1736 gg. (Ufa: Bashkirskoi Gosuniversitet, 1977)

I. G. Akmanov, "Chelobitnaia Bashkir Ufimskoi Provintsii na Imia Imperatritsy Rossii Anny Ivanovny s Svoikh Nuzhdakh ot 1733 g." Vatandash, 6, (2005) available at http://www.vatandash.ru/index.php?article=390 accessed on 14 July 2007

I. G. Akmanov, ed., Istoriia Bashkortostana s Drevneishikh Vremen do Nashikh Dnei, v. 1, (Ufa: Kitap, 2007)

I. G. Akmanov, Za Pravdivoe Osveshchenie Istorii Narodov (Ufa: Kitap, 1995)

I. G. Ilishev, ed., Salavat Iulaev, Entsiklopediia, (Ufa: Nauchnoe Izdatel’stvo, 2004)

I. G. Rozner, Iaik pered Burei, (Moskva: Mysl', 1966)

I. G. Rozner, Kazachestvo v Krest'ianskoi Voine 1773-1775 gg. (L'vov: Izd-vo L'vovskogo Universiteta, 1966)

I. M. Gabdrafikov, "Etnokulturnye Rezultaty Migratsionnykh Protsessov v Severo-Zapadnoi Bashkirii (Konets 16-Nachalo 20 v.)" in Etnologicheskie Issledovaniia v Bashkortostana, ed., I. M. Gabdrafikov, (Ufa: 1994), 22-28.

I. M. Gvozdikova, "Novye Dokumenty ob Areste Salavata Iulaeva" in Istoriia SSSR, 5. (1978), $141-146$

I. M. Gvozdikova, Bashkortostan Nakanune i v Gody Krest'ianskoi Voiny Pod Predvaditelskom Pugacheva, (Ufa: Kitap, 1999)

I. M. Gvozdikova, Salavat Iulaev, Issledvoanie Dokumental'nykh Istochnikov, (Ufa: Kitap, 1992)

I. Shishkin, “A. P. Volynskii” Otechestvennye Zapiski, 128 (1860), 724

I. Zhukovskii, Kratkoe Obozrenie Dostopamiatnykh Sobytii Orenburgskogo Kraia, Rospolozhennykh s 1246 po 1832 God Chinovnikom, Sostoiashchim pri Orenburgskom Voennym Gubernatore po Osobym Porucheniiam, (1832)

Ia. K. Grot, Materialy dlia Istorii Pugachevskogo Bunta, Bumagi Kara i Bibikova, (Sankt Petersburg: 1862)

Igor Shakino, Vasilii Tatishchev, (Sverdlovsk: Sredne-Ural'skoe Knizhnoe Izdatel'stvo, 1986) 
Isabella Kreindler, "Educational Policies toward the Eastern Nationalities in Tsarist Russia: A Study of Ilminskii's System" (PhD diss., Colombia University, 1969)

Istoriia Ufy: Kratkii Ocherk, (Ufa: Bashkirskoe Knizhnoe Izdatel'stvo, 1981)

Iu, N. Sergeev, Pravoslavnaia Tserkov v Bashkortostane Vtoraia Polovina 16-Seredine 19 Veka, (Ufa: Bashkirskii Universitet, 1996)

Iu. A. Limonov, Pugachev i Ego Spodvizhniki, (Moskva-Leningrad: Nauka, 1965)

Iu. A. Limonov, Vladimir V. Mavrodin and V. M. Paneiakh, Pugachev i Pugachevtsy, (Leningrad: Nauka, 1974)

Iu. A. Limonov, Vladimir V. Mavrodin and V. M. Paneiakh, Pugachev i ego Spodvizhniki, (Leningrad: Nauka, 1965)

Iu. M. Tarasov, "Russkaia Krest'ianskaia Kolonizatsiia Iuzhnogo Urala v 17 i 18 vv." Uchenye Zapiski Kishinevskie Gos. In-ta Seriia Istoricheskaia, 95, (1968)

Iu. M. Tarasov, Russkaia Krest'ianskaia Kolonizatsiia Iuzhnogo Urala: Vtoraia Polovina 18 Pervaia Polovina 19 v. (Moskva: Nauka, 1984)

Iu. N. Sergeev, "Tserkovno-Monastyrskoe Zemlevladenie v Bashkirii Konets 16-Seredina 18 v." Sotsial'no-Ekonomicheskoe i Politicheskoe Razvitie Bashkirii v Kontse 16-Nachale 20 vv. ed., I. M. Gvozdikova, Kh. F. Usmanov and M. I. Rodnov, (Ufa, 1992), 12-21

Iu. N. Smirnov, "Deiatel'nost' Orenburgskoi Ekspeditsii pod Rukovodstvom I. K. Kirilova v Zavolzh'e” Samarskii Zemskii Sbornik, 3, (1996), 54-63

Iu. Tatishchev, K Istorii Upravleniia V,. N. Tatishchevym Orenburgskoi Ekspeditsii 1737-1739 gg,( Moskva: 1901)

Iurii Smirnov, Orenburgskaia Ekspeditsiia i Prisoedinenia Zavolzhia k Rossii v 30-40-e gg 18 Veka,(Samara: Samara University, 1997)

J. P. Cole, Geography of the Soviet Union, (London: Butterworths, 1984)

James Axtell, Natives and Newcomers: The Cultural Origins of North America (Oxford: Oxford University Press, 2001)

James C. Scott, "Freedom and Freehold: Space, People, and State Simplification in Southeast Asia" Asian Freedoms: The Idea of Freedom in East and Southeast Asia, ed. David Kelly \& Anthony Reid, (Cambridge \& New York: Cambridge University Press, 1998), 37-64

James H. Merrell, The Indians' New World: Catawbas and Their Neighbors from European Contact through the Era of Removal (University of North Carolina Press, 2010) 
James Scott, "Patronage or Exploitation," in Patrons and Clients in Mediterranean Societies, ed. Ernest Gellner and John Waterbury, (London: Duckworth, 1977), 21-40

Jane Burbank and David L. Ransel, Imperial Russia: New Histories for the Empire (Bloomington: Indiana University Press, 1998)

Jane Burbank, Mark Von Hagen, and Anatoly Remnev, eds., Russian Empire: Space, People, Power, 1700-1930 (Bloomington: Indiana University Press, 2007)

Jarmo T. Kotilaine \& Marshall Poe, ed., Modernizing Muscovy: Reform and Social Change in Seventeenth-Century Russia, (London and New York:Routledge Curzon,2004)

Jarmo T. Kotilaine, "Mercantilism in Pre-Petrine Russia" in Modernizing Muscovy: Reform and Social Change in Seventeenth-Century Russia, ed. Jarmo Kotilaine \& Marshall Poe, (Routledge: London, 2004), 137-166

Jeff Sahadeo, "Conquest, Colonialism, and Nomadism on the Eurasian Steppe" Kritika:

Explorations in Russian and Eurasian History, 4, (Fall 2003), 942-954

Jere L. Bacharach, ed., Medieval Islamic Civilization 2 volumes: An Encyclopedia, (New York: Routledge, 2006)

Jeremy Adelman and Stephen Aron, "From Borderlands to Borders: Empires, Nation-States, and the Peoples in between in North American History" The American Historical Review, Vol. 104, No. 3 (Jun., 1999), 814-841

Jeremy H. Keenan, "Sedentarization and Changing Patterns of Social Organization amongst the Tuareg of Algeria", Nomadic Societies in the Middle East and North Africa: Entering the 21st Century ed. Dawn Chatty, (Leiden: Brill, 2006), 916-939

Jo-Ann Gross, "Historical Memory, Cultural Identity and Change: Mirza Abd al-aziz Sami's Representation of the Russian Conquest of Bukhara" Russia's Orient: Imperial Borderlands and Peoples, 1700-1917, ed., Daniel R. Brower, Edward J. Lazzerini (Bloomington: Indiana University Press, 1997), 203-226

John Ledonne, "Russia's Eastern Theater, 1650-1850: Springboard or Strategic Backyard" Cahiers du Monde Russe, v. 49, no: 1, (2008), 17-45

John Solomon Otto, The Southern Frontiers, 1607-1860: The Agricultural Evolution of the Colonial and Antebellum South, (New York: Greenwood Press, 1989)

John T. Alexander, Autocratic Politics in a National Crisis; The Imperial Russian Government and Pugachev's Revolt, 1773-1775,(Bloomington: Indiana University Press, 1969)

John T. Alexander, Emperor of the Cossacks: Pugachev and the Frontier Jacquerie of 17731775, (Lawrence, Kansas: Coronado Press, 1973) 
John W. Eadie, "Civitates and Clients: Roman Frontier Policies in Pannonia and Mauretania Tingitana" in The Frontier: Comparative Studies ed. David H. Miller and Jerome O. Steffen, (Norman: University of Oklahoma Press, 1977), 57-80

Joseph T. Fuhrmann, The Origins Capitalism in Russia: Industry and Progress in the 16-17th Centuries, (Chicago: Quadrangle Books, 1972)

Kazakhsko-Russkie Otnoshenie v 16-18 Vekakh: Sbornik Dokumentov i Materialov, (Alma Ata: Izdatel'stvo Akademii Nauk Kazakhskoi ASSR, 1961)

Kh. F. Usmanov, “Krest'ianskaia Kolonizatsiia Bashkirii v Poreformennyi Period” Stranitsy Istorii Bashkiri. Sbornik Statei, (Ufa: BFAN SSSR, 1974), 67-112

Kh. F. Usmanov, ed. Istoriia Bashkortostana s Drevneishikh Vremen do 60-kh Godov 19 v. (Ufa: Kitap, 1997)

Kh. I. Muratov, Krest'ianskaia Voina 1773-1775 gg. v Rossii, (Moskva: Voennoe izd-vo Ministerstva Oborony Soiuza SSR, 1954)

Kornet Stepanov, "Kargala ili Seitovskii Posad” Russkii Arkhiv,11, Section 2, (1897), 602-609

L. E Iofa, Sovremenniki Lomonosova: I. K. Kirilov and V. N. Tatishchev, Geografy Pervoi Poloviny 18 v. (Moskva: 1949)

L. I. Futorianskii, Istoriia Orenburzhia, (Orenburg: Orenburgskoe Knizhnoe Izdatel'stvo, 1996)

Lowell Tillett, The Great Friendship: Soviet Historians on the non-Russian Nationalities, (Chapel Hill: University of North Carolina Press, 1969)

M. A. Rakhmatullin, "Krest'ianskaia Voina v Rossii 1773-1775 Godov" Istoriia SSSR, 6 (1973), $35-53$

M. G. Masevich, Materialy po Istorii Politicheskogo Stroia Kazakhstana, v. 1, (Alma-Ata: Izdvo Akademii Nauk Kazakhskoi SSR, 1960)

M. G. Novlianskaia, I. K. Kirilov i ego Atlas Vserossiiskoi Imperii, (Moskva\&Leningrad: Izdatel'stvo Akademii Nauk SSSR, 1958)

M. G. Novlianskaia, Ivan Ivanovich Kirilov, Geograf 18 Veka (Leningrad: Nauka, Leningradskoe otd-nie, 1964)

M. G. Novlianskaia, Ivan Ivanovich Kirilov, Geograf 18 Veka,(Moskva-Leningrad: Nauka, 1964)

M. K. Liubavskii, Obzor Istorii Russkoi Kolonizatsii s Drevneishikh Vremen i do 20 Veka (Moskva: Izdatel'stvo Moskovskogo Universiteta, 1996) 
M. M. Kul'sharipov, Politika Tsarizma v Bashkortostane (1775-1800 gg.), (Ufa; RIO BashGU, 2003)

M. N. Farkhshatov, Narodnoe Obrazovanie v Bashkirii v Poreformennyi Period 60-90 e Gody 19 v.(Moskva: Nauka, 1994)

M. N. Farkshatov, "Dokumenty Orenburgskogo Magometanskogo Dukhovnogo Sobraniia po Istorii Mektebov i Mederese Bashkirii Vtoroi Poloviny 19 v." in Maloizuchennye Istochniki po Istorii Bashkirii, ed., N. M. Gvozdikova, R. G. Kuzeev, Kh. F. Usmanov, (Ufa: 1986), 34-43

M. N. Martynov, "Satkinskii Zavod vo Vremena Vosstaniia Emel'iana Pugacheva” Istoricheskie Zapiski, 58, (1956), 208-245

M. N. Martynov, Gornozavodskaia Promyshlennost na Urale Pri Petre I, (Sverdlovsk: Sverdlovskoe Oblastnoe Gosudarstvennoe Izdatel'stvo, 1945)

M. N. Tikhomirov \& P. P. Epifanov, Sobornoe Ulozhenie 1649 g. (Moskva:Izdatel'stvo Moskovskogo Universitetat, 1961)

M. N. Tikhomirov, "Prisoedinenie Chuvashii k Rossii" in Materialy po Istorii Chuvashkoi ASSR.

1. (Cheboksary, 1958)

M. Svirelin, "Kolonizatsiia Orenburgskogo Kraia v Pervoi Polovine 18 v." Drevniaia i Novaia Rossiia. v. 6-7, (1876), 178-243

M. V. Murzabulatov, "O Bashkirakh-Votchinnikakh” Askinskii Raion; Natsionalnyi Sostav Naselennykh Punktov po Perepisiam 18-20 Vekov,ed., K. A. Aralbaev, (Ufa: 2002), 23

Mahmut G. Mahmudov, Sterlibash: Gorzhus Tvoei Sud'boiu, (Ufa: Belaia Reka, 2000)

Marc Raeff, "Pugachev's Rebellion" in Major Problems in the History of Imperial Russia, ed. James Cracraft, (Lexington: D. C. Heath and Company, 1994), 188

Marc Raeff, Imperial Russia, 1682-1825, The Coming of Age of Modern Russia, (New York: Knopf, 1971)

Marc Raeff, Political Ideas and Institutions in Imperial Russia, (Boulder: Westview Press, 1997)

Marianne Schmink and Charles H Wood, Frontier Expansion in Amazonia, (Gainesville: University of Florida Press, 1984)

Marion Apostolov, The Christian-Muslim Frontier: A Zone of Contact, Conflict or Cooperation. (London and New York: Routledge\&Curzon, 2004) 
Mark von Hagen, "Empires, Borderlands, and Diasporas: Eurasia as Anti-Paradigm for the PostSoviet Era" American Historical Review 109, No: 2, (2004), 445-468

Martha Brill Olcott, The Kazakhs, $2^{\text {nd }}$ ed., (Stanford, California: Hoover Institution Press, 1995)

Mary McAuley, Russia's Politics of Uncertainty (New York: Cambridge University Press, 1997)

Materialy po Istorii Bashkirskoi ASSR Part 1

Materialy po Istorii Bashkirskoi ASSR Tom 2

Materialy po Istorii Bashkirskoi ASSR Tom 3

Materialy po Istorii Bashkirskoi ASSR Tom 4, Part 1

Materialy po Istorii Bashkirskoi ASSR Tom 4, Part 2

Materialy po Istorii Bashkirskoi ASSR Tom 5

Materialy po Istorii Bashkirskoi ASSR Tom 6

Matthew Lange, Lineages of Despotism and Development: British Colonialism and State Power, (Chicago: University of Chicago Press, 2009)

Matthew Paul Romaniello, “Absolutism and Empire: Governance on Russia's Early-Modern Frontier" (PhD diss., Ohio State University, 2003)

Matthew Paul Romaniello, "Controlling the Frontier: Monasteries and Infrastructure in the Volga Region, 1552-1682" Central Asian Survey 19 (2000), 429-443

Maureen Perrie, "Popular Revolts" in The Cambridge History of Russia: From Early Rus' to 1689, ed., Maureen Perrie, D. C. B. Lieven, Ronald Grigor Suny, (New York: Cambridge University Press, 2006), 604-605.

Michael Khodarkovsky, "Not by Word Alone" Comparative Studies in Society and History, v. 38, no: 2, (1996), 267-293

Michael Khodarkovsky, "The Conversion of Non-Christians in Early Modern Russia" in $O f$ Religion and Empire, Missions, Conversion, and Tolerance in Tsarist Russia, ed., Robert Geraci and Michael Khodarkovsky, (Ithaca and London: Cornell University Press, 2001), 115-143

Michael Khodarkovsky, Russia's Steppe Frontier; The Making of a Colonial Empire 1500-1800 (Bloomington \& Indianapolis: Indiana University Press, 2002) 
Michael Khodarkovsky, Where Two Worlds Met: The Russian State and the Kalmyk Nomads, 1600-1771 (Ithaca and London: Cornell University Press, 1992)

Munir Khadiev, "Istoriia Bashkir" Vatandash, 9, (2007) available atg http://www.vatandash.ru/index.php?article=1506 accessed on 26 May 2009

Mustafa Ozgur Tuna, "Imperial Russia’s Muslims; Inroads of Modernity” (PhD diss., Princeton University, 2009)

N. A. Abramov, "Materialy dlia Istorii Kristianskogo Prosveshcheniia Sibiri” Zhurnal Ministerstva Narodnago Prosveshcheniia, v. 81, no. 5, (1854), 15-54

N. A. Chuloshnikov, “K Istorii Bashkirskogo Zemlevladeniia i Russkoi Pozemel'noi Politiki Posle Ukaza 1832 Goda" Trudy Orenburgskogo Obshchestva Izucheniia Kirgizskogo Kraia, Vypusk 1 (Orenburg: 1921)

N. A. Firsov, "Polozhenie Inorodtsev v Moskovskom Gosudarstve" Uchenye Zapiski Kazanskogo Universiteta, v. 2, (Kazan', 1866)

N. A. Firsov, Inorodcheskoe Naselenie Prezhnego Kazanskogo Tsarstva v Novoi Rossii do 1762 Goda i Kolonizatsiia Zakamskikh Zemel'v Ego Vremia. Vol.6, (Kazan: 1871)

N. A. Mazhitov and A. N. Sultanova, Istoriia Bashkortostana s Drevneishikh Vremen do 16 Veka (Ufa: Kitap, 1994)

N. A. Popov, V. N. Tatishchev i Ego Vremia (Moskva: 1861)

N. F. Demidova, "Bashkirskaia Vosstaniia 30-kh Godov 18 v." in Materialy po Istorii Bashkirskoi ASSR: Orenburgskaia Ekspeditsiia i Bashkirskie Vosstaniia 30-kh Godov XVIII v. vol. 6, compiled by N. F. Demidova (Ufa: Kitap, 2002), 3-12

N. F. Demidova, "Upravlenie Bashkiriei v Pervoi Treti 18 v.” Istoricheskie Zapiski, 68 (1961), 219

N. F. Demidova, "Zemlevladenie i Zemle polzol'zovanie v Ufimskom Uezde v 16-17 vv." in Ezhegodnik po Agrarnoi Istorii Vostochnoi Evropy 1962 g. (Minsk: Izdatel'stvo Nauka i Tekhnika, 1964), 269-270

N. F. Dubrovin, Pugachev i Ego Soobshchiki, Epizod iz Istorii Tsarstvovaniia Imperatritsy Ekateriny II 1773-1774 gg. Po Neizdannym Istochnikam, 3 volumes, (1884)

N. G. Ustiugov, et., al., Ocherki po Istorii Bashkirskoi ASSR, v. 1, part 1, (Ufa: Bashkirskoe Knizhnoe Izdatel'stvo, 1956)

N. I. Nikitin, Sluzhilye Liudi v Zapadnoi Sibiri 17 Veka (Novosibirsk: Nauka, 1988) 
N. M. Katanov and I. M. Pokrovskii, "Otryvok iz Odnoi Tatarskoi Letopisi o Kazani i

Kazanskom Khanstve" Izvestiia Obshchestva Arkheologii, Istorii, i Etnografii pri Imperatorkom Kazanskom Universitete, 21 (Kazan 1905), 319

N. M. Kulbakhtin, \& Iu. N. Sergeev, "Religioznaia Politika Tsarizma v Bashkirii" in SotsialnoEkonomicheskoe Razvitie i Klassovaia Borba na Iuzhnom Urale i v Srednem Povolzhe

Dorevoliutsionnyi Period ed., I. G. Akmanov, (Ufa: Bashkirskii Universitet, 1988), 38-39.

N. M. Kulbakhtin, "Dinastiia Gornozavodchikov Osokinykh” Vatandash, 7, (2000), 81-93

N. M. Kulbakhtin, "Iderkai Baimekov," in Bashkirskaia Entsiklopediia, ed. I. G. Akmanov and Aznagul Uruskulov, v. 3, (Ufa: Nauchnoe Izdatel’stvo, 2005), 132

N. M. Kulbakhtin, Gornozavodskaia Promyshlennost v Bashkortostane 18 Vek, (Ufa: Kitap, 2000)

N. M. Kulbakhtin, Nakazy Narodov Bashkortostona v Ulozhennuiu Komissiiu 1767-1768 gg. (Ufa: Kitap, 2005)

N. N. Firsov, Dvukhsotletnei pamiati I.I. Nepliueva - riechi, (Kazan: 1894)

N. N. Firsov, Inorodcheskoe Naselenie Prezhnego Kazanskogo Tsarstva v Novoi Rossii do 1762 g. i Kolonizatsiia Zakamskikh Zemel'v Ego Vremia (Kazan; 1869)

N. V. Gorban', “Krest'ianstvo Zapadnoi Sibiri v Krest'ianskoi Voine 1773-1775 gg.” Voprosy Istorii, 11, (1952)

N. V. Popov, Tatishchev i ego Vremia, (1861)

N. V. Ustiugov, "Bashkirskoe Vosstanie 1662-1664 gg.” Istoricheskie Zapiski, 24 (1947), 30110

N. V. Ustiugov, “O Kharaktere Bashkirskikh Vostanii 17-Pervoi Poloviny 18 vv.” Materialy Nauchnoi Sessii posviashchennoi 400-letiiu prisoedineniia Bashkirii k Russkomu Gosudarstvu, ed. N. V. Ustiugov and R. G. Kuzeev, (Ufa: 1958), 86-126

N. V. Ustiugov, “Osnovnye Cherty Kolonizatsii Iuzhnogo Zaural'ia v 18 v.” Voprosy Istorii Sibiri i Vostoka, (Novosibirsk: 1961), 67-74

N. V. Ustiugov, Bashkirskoe Vosstanie, 1737-1739 gg. (Izdatel'stvo Akademii Nauk SSSR: Moskva-Leningrad; 1950)

N. V. Ustiugov, et.al., Ocherki Po Istorii Bashkirskoi ASSR, v. 1, part 1, (Ufa: Bashkirskoe Knizhnoe Izdatel'stvo, 1956) 
N. V. Vitevskii, Nepliuev i Orenburgskii Krai v Prezhnem ego Sostave do 1758 g. Part 1 (Kazan: 1891)

Nancy Shields Kollmann, "Muscovite Patrimonialism" in Major Problems in the History of Imperial Russia, ed. James Cracraft, (Lexington, Massachussets: D. C. Heath, 1994), 37-46

Nancy Shields Kollmann, "Society, Identity, and Modernity in Seventeenth Century Russia" in Modernizing Muscovy: Reform and Social Change in Seventeenth-Century Russia, ed., Jarmo Kotilaine, Marshall Poe, (London \& New York: Routledge, 2004), 421.

Nazir Kulbakhtin "Nachalo. Ivan Groznyi i Bashkiry” Panorama Bashkortostana, 34 (Mart, 2008), 34

Nazir Kulbakhtin "Zhalovannye Gramoty Ivana Groznogo Bashkiram” Vatandash (Sentiabr, 2007) available at http://www.vatandash.ru/index.php?article $=1505$ accessed on accessed on 26 May 2009

Nikolai Chernavskii, “Orenburgskaia Eparkhiia v Proshlom i Nastoiashchem” Trudy Orenburgskoi Uchenoi Arkhivnoi Kommissii Vypusk 1 (1900), 101-105

Ole Bruun, Precious Steppe: Mongolian Nomadic Pastoralists in Pursuit of the Market, (Lanham, MD.: Lexington Books, 2006)

Orcutt William Frost, Bering: The Russian Discovery of America, (New Haven: Yale University Press, 2003)

P. Blau, Exchange and Power in Social Life (New York: J. Wiley, 1964)

P. I. Rychkov, Istoriia Orenburgskaia, 1730-1750, (Orenburg: 1896)

P. I. Rychkov, Topografiia Orenburgskoi Gubernii (Ufa: Kitap, 1999)

P. Ishcherikov, Ocherki iz Istorii Kolonizatsii Bashkortostana: Ot Zavoevanii Bashkortostana do Epokhi Raskhishcheniia Bashkirskikh Zemel, (Ufa: Kitap, 2003)

Pal Kolsto, Nation-Building and Common Values in Russia, (Lanham: Rowman \& Littlefield Publishers, 2004)

Paul Avrich, Russian Rebels, 1600-1800, (New York \& London: W. W. Norton Company, 1972)

Paul Georg Geiss, Pre-Tsarist and Tsarist Central Asia: Communal Commitment and Political Order in Change, (Routledge: New York, 2003)

Paul W. Werth, "Coercion and Conversion: Violence and the Mass Baptism of the Volga Peoples, 1740-55”, Kritika: Explorations in Russian and Eurasian History, v. 4, no: 3, (2003), 565. 
Permskaia Letopis, Pervyi Periods 12631613 gg., (Perm:1881)

Permskaia Letopis, Vtoroi Period, s 16131645 gg. (Perm: 1881)

Perry Anderson, Lineages of Absolutism (London: Verso, 1979)

Peter Stern, "The White Indians of the Borderlands" Journal of the Southwest, v. 33, no. 3 (Autumn, 1991), 263.

Petr Ishcherikov, Ocherki iz Istorii Kolonizatsii Bashkortostana: Ot Zavoevaniia Bashkortostana do Epokhi Pashkishcehiia Bashkirskikh Zemel' (Ufa: Kitap, 2003)

Pismo Batyrshi Imperatritse Elizavete Petrovne, (Ufa: Ufimskii nauchnyi tsentr RAN, 1993)

Pol'noe Sobranie Russkoi Letopisei. v.13, part 1, (1907)

Polnoe Sobranie Zakonov Russkoi Imperii, Various Volumes

R. B. Ovchinnikov, et.al., Dokumenty Stavki E. I. Pugacheva, Povstancheskikh Vlastei i

Uchrezhdenii, 1773-1774 gg. (Moskva: Nauka, 1975)

R. Douglas Hurt, The Ohio Frontier: Crucible of the Old Northwest, 1720-1830, (Bloomington: Indiana University Press, 1996)

R. G. Bukanova, Goroda i Gorodskoe Naselenie Bashkirii v 16-17 vv. (Ufa: Bashgosuniversitet, 1993)

R. G. Bukanova, Goroda-Kreposti Iugo-Vostoka Rossii v 18 Veke Istoriia Stonovleniia Gorodov na Territorii Bashkirii (Ufa: Kitap, 1997)

R. G. Kuzeev \& B. Kh. Iuldashbaev, 400 Let vmeste s Russkim Narodom; Prisoedinenie Bashkirii k Russkomu Gosudarstvu i ego Istoricheskoe Znachenie, (Ufa: Bashkirskoe Knizhnoe izd-vo, 1957)

R. G. Kuzeev and R. V. Ovchinnikov, comp., Krest'ianskaia Voina 1773-1775 gg na Territorii Bashkirii, Sbornik Dokumentov, (Ufa: Bashkirskoe Knizhnoe Izdatel'stvo, 1975)

R. G. Kuzeev, "Dobrovol'noe Prisoedinenie Bashkirii k Russkomu Gosudarstvu: Povorotnyi Punkt v Istorii Kraia" in Istoricheskoe Znachenie Dobrovol'nogo Prisoedineniia Bashkirii k Russkomu Gosudarstvu: Materialy Nauchnoi Konferentsii, ed. R. G. Kuzeev, (Ufa: Bashkirskoe Knizhnoe Izdatel'stvo, 1982), 06 - 25

R. G. Kuzeev, Arkheologiia i Etnografiia Bashkirii, v. 3, (Ufa: 1968)

R. G. Kuzeev, Bashkirskie Shezhere (Ufa: Bashkirskoe Knizhnoe Izdatel'stvo, 1960) 
R. G. Kuzeev, ed. Arkheologiia i Etnografiia Bashkirii, 3 (Ufa: 1968)

R. G. Kuzeev, Istoricheskaia Etnografiia Bashkirskogo Naroda (Ufa: Bashkirskoe Knizhnoe Izdatel'stvo, 1978)

R. G. Kuzeev, Ocherki Istoricheskoi Etnografii Bashkir (Rodo-plemennye Organizatsii Bashkirv 17-18 vv.) (Ufa: Bashkirskoe Knizhnoe Izdatel'stvo, 1957)

R. G. Kuzeev, trans., Bashkirskie Shezhere, (Ufa: Bashkirskoe Knizhnoe Izdatel'stvo, 1960)

R. M. Raimov, 1905 God v Bashkirii: Revoliutsionnoe Dvizhenie v 1905-1907 gg. (Moskva \& Leningrad: Izdatel'stvo Akademii Nauk SSSR, 1941)

R. N. Zinurov, "Istoricheskie Paralleli Nachala Kolonizatsii Bashkortostana i Severnoi Ameriki" Iadkiar, 2 (1999), 76-88

R. N. Zinurov, “Kolonizatsiia Bashkortostana i Severnoi Ameriki” Vatandash, 2, (1998), 87-97

R. N. Zinurov, Bashkirskie Vosstaniia i Indeiskie Voiny: Fenomen v Mirovoi Istorii (Ufa: Gilem, 2001)

R. V. Ovchinnikov, Sledstvie i Sud nad E. I. Pugachevym i ego Spodvizhnikami:

Istochnikovedcheskoe Issledovanie, (Moskva: Rossiiskaia Akademiia Nauk, 1995)

R. Z. Ianguzin, and F. G. Khisamutdinova, Korennye Narody Rossii; Bashkiry, (Ufa: Kitap, 2007)

R. Z. Ianguzin, Etnografiia Bashkir (Ufa: Kitap. 2002)

R. Z. Ianguzin, Khoziaistvo Bashkir Dorevoliutsionnoi Rossii (Ufa: Bashkirskoe Knizhnoe Izdatel'stvo, 1989)

R. Z. Shakurov, ed., Bashkortostan: Kratkaia Entsiklopediia (Ufa: Nauchnoe Izdatel'stvo, 1996)

Rashit Iskandarov, Seitov Posad: Ocherki po Istorii Orenburgskoi (Tatarskoi) Kargaly (Kazan: Tatarskoe Knizhnoe Izdatel'stvo, 2005)

Ravil' Bukharaev, Islam in Russia: The Four Seasons (New York, St. Martin's Press, 2000)

Ravil' Bukharaev, The Model of Tatarstan: Under President Mintimer Shaimiev, (New York: St. Martin Press, 1999)

Richard Hellie, "The Economy, Trade and Serfdom" in The Cambridge History of Russia: From early Rus' to 1689, Volume 1, From Early Rus to 1689. ed. Maureen Perrie, D. C. B. Lieven, Ronald Grigor Suny, (Cambridge \& New York: Cambridge University Press, 2006), 539-558 
Richard Hellie, "The Expanding Role of the State in Russia" in Modernizing Muscovy; Reform and Social Change in Seventeenth-Century Russia, ed., Jarmo T. Kotilaine, \& Marshall Poe, (London: Routledge, 2004), 42-43.

Richard Hellie, trans., The Muscovite Law Code (Ulozhenie) of 1649, Part 1, (Irvine, California: Charles Schlacks jr., 1988)

Richard Nelson Frye, Ibn Fadlan's Journey to Russia: a Tenth-Century Traveler from Baghdad to the Volga River, (Princeton: Markus Wiener Publishers, 2005)

Richard Pipes, Russia under the Old Regime (New York: Charles Scribner's Sons, 1974)

Richard W. Bulliet, Conversion to Islam in the Medieval Period; An Essay in Quantitative History, (Cambridge: Harvard University Press, 1979)

Richard White, The Middle Ground; Indians, Empires and Republics in the Great Lakes Region, 1650-1815 (Cambridge: Cambridge University Press, 1991)

Robert D. Crews, "Allies in God's Command; Muslim Communities and the State in Imperial Russia” (PhD diss., Princeton University, 1999)

Robert D. Crews. For Prophet and Tsar: Islam and Empire in Russia and Central Asia. (Cambridge, Mass.: Harvard University Press, 2006)

Robert F. Berkhofer, Jr., "The Political Context of a New Indian History," Pacific Historical Review, 40, No. 3 (Aug., 1971): 357-382.

Robert Gordon Latham, The Native Races of the Russian Empire, (London: 1855)

Robert P. Geraci and Michael Khodarkovsky, eds., Of Religion and Empire: Missions, Conversion, and Tolerance in Tsarist Russia (Ithaca, NY: Cornell University Press, 2001)

Roger Portal, "Industrializatsiia Iuzhnogo Urala 1745-1762 Gody" Vatandash, 9. (2002) available at http://www.vatandash.ru/index.php?article=1221 accessed on 26 May 2009

Roger Portal, Rossia i Bashkiry; Istoriia Vzaimootnosheniia 1662-1798, 11; available at http://kraeved.opck.org/biblioteka/bashkortostan/rossia_i_bashkiri/rossia_i_ bashkiri.pdf accessed on 7 April 2008

Roger Portal, Russes et Baćkirs: Aux XVII et XVIII Siěcles(1662-1798), 30 ; It's Russian translation is available at http://kraeved.opck.org/biblioteka/ural/ural_xviii_v/ural_xviii_v.pdf accessed on 7 April 2008 
Romila Thapar, Early India: From the Origins to AD 1300, (Berkeley, Calif.: University of California Press, 2002)

Ronald G. Suny, "The Russian Empire" After Empire; Multiethnic Societies and Nation Building; The Soviet Union and the Russian, Ottoman and Habsburg Empires ed. Karen Barkey \& Mark von Hagen, (Westview Press: Boulder, Colorado, 1997), 142-153

Ronald Robinson, "Non-European Foundations of European Imperialism: Sketch for a Theory of Collaboration," in Studies in the Theory of Imperialism, ed. Roger Owen and Bob Sutcliffe (London: Longman, 1972), 117-42.

Rudolph L. Daniels, V. N. Tatishchev: Guardian of the Petrine Revolution, (Philadelphia: Franklin Publishing Company, 1973)

Rustem Basyrov and Svetlana Basyrova, "Tatarskoe Kupechestvo v Rossiisko-Aziatskoi Torgovle v 18 Stoletii” in Bel'skie Prostory, No. 2, 2005.Available online at http://www.hrono.ru/text/2005/basyr02_05. html accessed on 20 November 2010

S. Bekbulatov, "Bashkirskie Vostaniia i Tatary" Vestnik Nauchnogo Obshchestva Tatarovedeniia 9-10 (1930): 67

S. G. Pushkarev, Obzor Russkoi Istorii (New York: Izdatel'stvo Imeni Chekhova, 1953)

S. G. Runkevich, Uchrezhdenie i Pervonachal'noe Ustoristvo Sviateishego

Previtel'stvuiushchego Sinoda (1721-1725 gg.), (Sankt-Peterburg: 1900)

S. I. Rudenko, Bashkiry: Istoriko - Etnograficheskie Ocherki (Moskva \& Leningrad: Izdatel'stvo Akademii Nauk SSSR:, 1955)

S. M. Prozorov, ed., Islam na Territorii Byvshei Rossiiskoi Imperii, Entsiklopedicheskii Slovar, Vol. 1, (Moskva: Vostochnaia Literatura, 2006)

S. M. Vasil’ev, Stranitsy Istorii Bashkirii, (Ufa: 1974)

S. S. Dreizen and E. I. Indova, Krest'ianskaia Voina 1773-1775 gg. v Rossii, (Vosstanie Pugacheva). Dokumenty iz Sobraniia Gos. Ist. Muzeia.(Moskva: Nauka, 1973)

S. T. Aksakov, The Family Chronicle, (New York: E. P. Dutton \& Co., Inc., 1961)

S. U. Taimasov, "Rol' Orenburgskoi Ekspeditsii v Prisoedinenii Bashkirii k Rossii (1730-e gg.)" Voprosy Istorii, 2, (2008), 145-146

Salavat Taimasov, "Aldar Kusiumovskoe Vosstanie i Politicheskoe Polozhenie Bashkortostana v Pervoi Treti 18 Veka", Vatandash, 8, (2008) available at http://www.vatandash.ru/index.php?article=1673 accessed on 24 June 2009 
Salavat Taimasov, "O Chislennosti Bashkir, o Starshinakh i Tarkhanakh v Period Obrazovaniia Orenburgskoi Gubernii" Vatandash, (Oktiabr' 2006) available at

http://www.vatandash.ru/index.php?article=331, accessed on 14 July 2007

Salavat Taimasov, Vosstanie v Bashkortostane 1773-1775 gg., (Ufa: Kitap, 2000)

Salavat U. Taimasov, "Rol' Orenburgskoi Ekspeditsii v Prisoedinenii Bashkirii k Rossii (1730-e gg.)” Voprosy Istorii, 2 (2008), 144-149

Sbornik Imperatorskogo Russkago Istoricheskago Obshchestva, 84, (1893), 176

Sehabeddin Mercani, Mustefadu'l-Ahbar fi Ahval'i Kazan ve Bulgar, (Ankara: Ankara Kultur Merkezi Yayini, 2008)

Sergei M. Soloviev, History of Russia, vol. 10: The Reign of Ivan the Terrible; Kazan, Astrakhan, Livonia, the Oprichnina and Polotsk Campaign, (Gulf Breeze, Fl.: Acad. Internat. Press, 1995)

Sergei M. Soloviev, History of Russia, vol. 21: The Tsar and the Patriarch, (Academic International Press, 2000)

Sergei M. Soloviev, History of Russia, vol. 23: Tsar Alexis, A Reign Ends (Academic International Press, 1998)

Sergei M. Soloviev, History of Russia: Peter the Great, the Great Reforms Begin. v. 29, (Academic International Press, 1981)

Sh. I. Tipeev, Ocherki po Istorii Bashkirii (Ufa: Bashkirskoe gos. izd-vo, 1930)

Shireen T. Hunter, Jeffrey L. Thomas, Alexander Melikishvili, Islam in Russia: The Politics of Identity and Security (Armonk, N.Y.: M.E. Sharpe, 2004)

Shoshana Keller, To Moscow, not Mecca: The Soviet Campaign against Islam in Central Asia, 1917-1941, (Westport, Conn.: Praeger, 2001)

Simon Dixon, Catherine the Great, (HarperCollins e-books, 2001)

Stephen Williams \& Gerard Friell, Theodosius: The Empire at Bay, (Routledge: London, 1998)

T. M. Aminov, M. G. Valeeva and Iu. N. Sergeev, "Dukhovnoe Obrazovanie" in Bashkirskaia Entsiklopediia, v.2, ed., I. G. Akmanov and Aznagul Uruskulov, (Ufa: Nauchnoe Izdatel'stvo, 2005), 530.

Terry Martin, “The Empire's New Frontiers: New Russia's Path from Frontier to Okraina, 17741920” Russian History, v. 19, No: 1-4 (1992), 181 
Thomas M. Barrett, At the Edge of Empire: The Terek Cossacks and the North Caucasus Frontier, 1700-1860 (Boulder-Colorado: West View Press, 1999)

U. Kh. Rakhmatullin, Naselenie Bashkirii v 17-18 vv Voprosy Formirovanie Nebashkirskogo Naselenia, (Moskva: Nauka, 1988)

U. Kh. Rakhmatullina, "Krest'ianskoe Zaselenie Bashkirii v 17-18 vv." in Krestianstvo $i$ Krestianskoe Dvizhenie v Bashkirii v 17-Nachale 20 vv. ed. Kh. F. Usmanov, (Ufa: 1981), 9.

V. A. Kuznetsov, "Novaia Zakamskaia Liniia i Obrazovanie Landmilitsii” Izvestiia Samarskogo Nauchnogo Tsentra Rossiiskoi Akademii Nauk, 11, (2009), 35.

V. A. Novikov, "Ocherk Kolonizatsii Bashkirskogo Kraia” Istoricheskaia Biblioteka, v. 3, no:12 (1878)

V. A. Novikov, Sbornik Materialov dlia Istorii Ufimskogo Dvorianstvo, (Ufa, 1879)

V. A. Oborin, "Migratsiia Mestnogo Naseleniia i ikh Rol v Osvoenii Urala v 16-17 vv." Istoriia USSR, v. 4, (1974), 69

V. D. Dimitriev, Chuvashskie Istoricheskie Predaniia (Cheboksary: Chuvashskoe Knizhnoe Izdvo, 1993)

V. D. Puzanov, "Bashkirskie Vosstania 17-18 Vekov v Isetsko-Pritobolskom Regiona (Iuzhnie Zaurale)" Shadrinskaia Starina, 7, (1999), 133-144

V. G. Semionov and V. P. Semiovna, Gubernatory Orenburgskogo Kraia (Orenburg:

Orenburgskoe Knizhnoe Izdatel'stvo, 1999)

V. I. Filonenko, "Bashkiry, Poddanstvo Bashkir Rossii. Bashkirskie Predaniia i Istoricheskie

Svedeniia ob Etom Poddanstve" Vestnik Orenburgskogo Uchebnogo Korpusa, Otdel 3, No. 7-8, Ufa, (1913), 226

V. I. Filonenko, "Bashkiry" Vestnik Orenburgskogo Uchebnogo Okruga, Section 3, No. 7-8, (Ufa: 1913), 225-226

V. I. Lebedev, "Bashkirskie Vosstanie 1705-1711 gg.” Istoricheskie Zapiski, 1, (1937), 81-102

V. Illeritskii, "Ekspeditsii Kniazia Cherkasskogo v Khivu” Istoricheskii Zhurnal, (1940), 40-51

V. M. Cheremshanskii, Opisanie Orenburgskoi Gubernii i Khoziaistvenno-Statisticheskom, Etnograficheskom i Promyshlennom Otnosheniakh, (Ufa, 1859)

V. M. Kabuzan, Izmenenia v Razmeshchenii Naseleniia Rossii: V 18 - Pervoi Polovine 19 v. Po Materialam Revizii (Moskva: Nauka, 1971) 
V. M. Paneiakh, "O Stepeni Uchastiia Narodnostei Bashkirii v Krest'ianskom Voine 1773-1775 gg. na Pervom ee Etape" in Uchenie Zapiski Permskogo Universiteta, 158, (Perm, 1966), 51-52.

V. N. Eliseeva, Kratkii Ocherk Istorii Cheliabinskoi Oblasti, (Cheliabinsk: Iuzhno-Ural'skoe Izd. , 1965)

V. N. Tatishchev, Leksikon Rossiiskoi Istoricheskoi Geograficheskoi, Politicheskoi i

Grazhdanskoi. (Leningrad: 1977)

V. N. Vitevskii, I. I. Nepliuev i Orenburgskii Krai v Prezhnem Ego Sostave do 1758, Three volumes (Kazan: 1889-1897)

V. Pistolenko, Iz Proshlogo Orenburgskogo Kraia, (Oblastnoe Izdatel'stvo: Chkalov, 1939)

V. V. Boguslavskii, Slavianskaia Entsiklopediia, v.1, (Moskva: Olma-Press, 2004)

V. V. Mavrodin, ed., Krest'ianskaia Voina v Rossii v 1773-1775 godakh, Vosstanie Pugacheva, v. 2, (Leningrad: Izdatel'stvo Leningradskogo Universiteta, 1966)

V. V. Veliaminov-Zernov, "Pamiatnik s Arabsko-Tatarskoi Nadpis'iu v Bashkirii" Trudy Vostochnogo Arkheologicheskogo Obshchestva, Part 4, (1859), 267-273

V. Zabirov, "Novye Istochniki ob Uchastii Natsionalov v Pugachevshchina" Problemy Istochnikovedeniia, 1. (1933), 37

Vakhit Imamov, Zapriatannaia Istoriia Tatar: Natsional'no-Osvoboditel'naia Bor'ba Tatarskogo Naroda v 16-18 Vekakh za Sozdanie Nezavisimogo Gosudarstvo (Naberezhnye Chelny: Gazetno-Knizhnoe Izd-vo, 1994)

Vladimir V. Mavrodin, Krest'ianskaia Voina v Rossii v 1773-1775 Godakh: Vosstanie

Pugacheva (Leningrad: Izd-vo Leningradskogo Universiteta, 1961)

Vladimir V. Mavrodin, Pod Znamenem Krest'ianskoi Voiny (Moskva: Mysl', 1974)

W. Bruce Lincoln, The Conquest of a Continent: Siberia and the Russians, (New York: Random House, 1994)

Willard Sunderland, "Empire in Boris Mironov's Sotsial'naia Istoriia Rossii," Slavic Review 60, (Autumn 2001), 573.

Willard Sunderland, Taming the Wild Field: Colonization and Empire on the Russian Steppe (Ithaca, N.Y.: Cornell University Press, 2004)

William Cronon, George Miles and Jay Gitlin, "Becoming West: Toward a new Meaning for Western History" in Under an Open Sky; Rethinking America's Western Past, ed. William Cronon (New York: W. W. Norton \& Company, 1992), 19. 
Wixman Ronald, The Peoples of the USSR: An Ethnographic Handbook, (Armonk, N.Y. : M.E. Sharpe, 1984)

Yakup Deliomeroglu, "Baskurt Isyanlari," in Turkler, v. 18, ed. Hasan Celal Guzel (Ankara: Yeni Turkiye Yayinlari, 2002), 430.

Z. I. Siraev, "O Kharaktere Bashkirskikh Vostanii 17-Pervoi Poloviny 18 vv. (1662-1664 gg.; 1681-1683 gg.; 1704-1711 gg.; 1735-1740 gg.)” in Iz Istorii Bashkirii Part 2, ed., R. G. Kuzeev, (Ufa:1963), 21.

Z. Kasymbaev, "Ekspeditsiia Bukhgoltsa i Sozdanie Priirtyshskikh Krepostei v Nachale 18 Veka" Istoricheskie Nauki, 1. (1974), 33-39

Zh. V. Drobnaia, "Ural'skie Goroda-Zavody kak Osnova Ekonomicheskogo Mogushchestva Rossiiskogo Gosudarstva v 18 v." Vtorye Tatishchevskie Chteniia, (1999), 52

Zufar Enikeev, Pravovoi Status Bashkortostana v Sostave Rossii, Istoriko-Pravovoe Issledovanie (Ufa: Gilem, 2002) 